Hermann Sautter

Rolf Schinke (eds.)

\title{
Social Justice in a Market Economy
}




\section{Hermann Sautter \\ Rolf Schinke (eds.)}

\section{Social Justice in a Market Economy}

Latin American market-oriented reforms along the lines of the Washington Consesus need to be supplemented by a number of social policies to achieve a more equitable society. While there has been considerable progress in enhancing the efficiency, much less has been made with regard to improving the social situation. Germany has a long and successful tradition of a social market economy. However, developments in recent years have shown various pitfalls in the current economic and social security systems and the need for appropriate adjustments. Therefore, Germany as well as most Latin American countries have to look for new solutions to combine social justice with economic efficiency. This volume address some of the most pertinent problems in this respect.

Hermann Sautter: Director of the Ibero-America Institute for Economic Research (IAI) and economics professor at University of Goettingen (since 1992), University of Frankfurt (1978-1992). Member of the Scientific Council of the Federal Ministry for Economic Cooperation and Development (since 1988) and Chairman of the Committee for Developing Countries of the German Economics Association (1988-1992).

Rolf Schinke: Academic Director at the Ibero-America Institute for Economic Research (IAI); member of an EU mission to Central America (1990-1992); head of a joint research project with the Catholic University, Chile, the University of Chile and the IAI. 
Social Justice in

a Market Economy

Hermann Sautter and Rolf Schinke - 978-3-631-75369-9

Downloaded from PubFactory at 01/11/2019 05:49:21AM

via free access 


\section{Göttinger Studien zur Entwicklungsökonomik Göttingen Studies in Development Economics}

Herausgegeben von/Edited by Hermann Sautter

Band 9

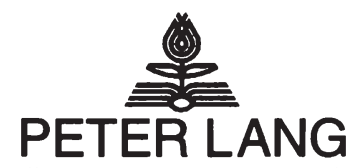

Frankfurt am Main - Berlin · Bern · Bruxelles - New York · Oxford - Wien 
Hermann Sautter/Rolf Schinke (eds.)

\section{Social Justice \\ in a Market Economy}

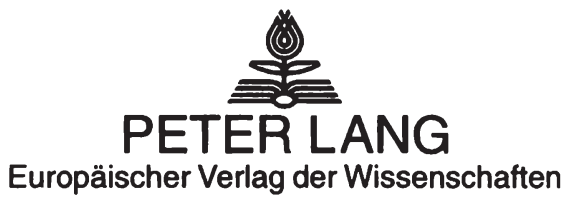


Die Deutsche Bibliothek - CIP-Einheitsaufnahme

Social Justice in a market economy / Hermann Sautter ; Rolf Schinke (eds.). - Frankfurt am Main ; Berlin ; Bern ; Bruxelles ; New York ; Oxford ; Wien : Lang, 2001

(Göttingen studies in development economics ; Vol. 9)

ISBN 3-631-37773-8

Open Access: The online version of this publication is published on www.peterlang.com and www.econstor.eu under the international Creative Commons License CC-BY 4.0. Learn more on how you can use and share this work: http://creativecommons. org/licenses/by/4.0.

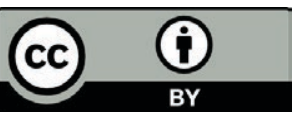

This book is available Open Access thanks to the kind support of ZBW - Leibniz-Informationszentrum Wirtschaft.

\author{
ISSN 1435-3395 \\ ISBN 3-631-37773-8 \\ US-ISBN 0-8204-5375-7 \\ ISBN 978-3-631-75369-9 (eBook) \\ (C) Peter Lang GmbH \\ Europäischer Verlag der Wissenschaften \\ Frankfurt am Main 2001 \\ All rights reserved.
}

All parts of this publication are protected by copyright. Any utilisation outside the strict limits of the copyright law, without the permission of the publisher, is forbidden and liable to prosecution. This applies in particular to reproductions, translations, microfilming, and storage and processing in electronic retrieval systems.

Printed in Germany 123467 


\section{Contents}

Foreword

Hermann Sautter, Rolf Schinke

„Social Justice" - its Meaning and its Implementation

in a Market Economy

Hermann Sautter

Indicators of Social Justice in Latin America:

A Matter of Concern?

Rolf Schinke

The Institutional Framework of a Social Market Economy

Hans Jürgen Rösner

Harmonizing Equity with Growth:

The Role of Educational Policy

Knut Gerlach

Harmonizing Equity with Growth:

The Role of Health Policy

J.-Matthias Graf von der Schulenburg

Ongoing Reforms of Latin American Health Systems:

Can Market-Oriented Reforms Help to Solve the Problem?

Klaus Liebig

The German Labor Market Institutions -

Will They Meet the Demand of Globalization and Europeanization?

Peter Rühmann

Old-Age Security: Design and Effects of Pension Schemes:

Some Basic Aspects

Winfried Schmähl

„Social Justice“ in a Market Economy -

Some Results of the Discussion

Hermann Sautter

The Authors 
Hermann Sautter and Rolf Schinke - 978-3-631-75369-9

Downloaded from PubFactory at 01/11/2019 05:49:21AM

via free access 


\section{Foreword}

The articles in this volume of the Ibero-America Institute's Göttinger Studien series are the revised versions of papers presented at the first Summer School on "Social Justice in a Market Economy" held in September 1999 in Göttingen. Participants were 25 young economists and political scientists from eleven Latin American countries. The main idea behind this event was to demonstrate that reforms can have a rather different shape, especially with respect to their social component. There is an increasing understanding that market-oriented reforms along the lines of the Washington Consensus need to be supplemented by a number of social policies to achieve a more equitable society. While there has been considerable progress in enhancing the economic efficiency, much less progress has been made with regard to improving the social situation. However, any market-oriented reform will be sustainable only when combining the objectives of efficiency and equality. Germany has a long and successful tradition of a social market economy. However, developments in recent years have shown various pitfalls in the current economic and social security systems and the need for appropriate adjustments. Therefore, Germany as well as most Latin American countries have to look for new solutions to combine social justice with economic efficiency.

The objective of the summer school was to discuss the need and potential for reforms that seek to reconcile efficiency with equity. The German type of a market economy served as a guideline. Two main questions evolved: Can the German experience with market economies help to re-design reform policies in Latin America and can the Latin American experience help to overcome the stagnation of Germany's reform process.

The summer school was realized in cooperation with the Konrad Adenauer Foundation whose financial and administrative support is greatly acknowledged. Further, we want to thank the scientific staff of the institute. Felicitas Nowak-Lehmann, Matthias Blum and Susanne Hesselbarth provided invaluable help in the preparation of the summer school and in leading the discussions during the working group sessions. Our special thanks go to Mrs. Margret von Schierstaedt who re-formatted the papers according to the recommendations of our new publisher Peter Lang and to Mrs. Weiss from the Konrad Adenauer Foundation who was responsible of the local travel arrangements. Her secretarial help is greatly acknowledged. Editorial assistance has been provided by Matthias Blum.

Göttingen, August 2000

Hermann Sautter and Rolf Schinke 
Hermann Sautter and Rolf Schinke - 978-3-631-75369-9

Downloaded from PubFactory at 01/11/2019 05:49:21AM

via free access 


\title{
„Social Justice” - its Meaning and its Implementation in a Market Economy
}

\author{
Hermann Sautter
}

\section{On the unavoidability of a cumbersome notion}

The demand for social justice is ubiquitous. Thus, nobody who wants to participate in the ongoing discussion on political and economic issues can avoid this notion. This applies for European as well as for North- and South American countries. It is also one of the central topics in Africa and Asia, not to mention the East European nations in process of transformation. Let me give some examples.

At present, the leaders of the British and the German Social Democrats are pushing their parties towards „modernism". Their slogans -expressed in the Blair/Schröder-paper - are much the same as those being heard from the other side of the political spectrum: „self-responsibility", „competition", „lean government" etc. The criticism came promptly, and it was raised from within the Social Democratic Parties themselves. One of the prominent members of the German party said: „Our society suffers from a gap of justice; we strive for ,modernism' and for ,competitive strength', but the Blair/Schröder-paper is neglecting social justice, which is intolerable."

Supposedly people in the United States are less interested in „social justice” than Europeans are. The corresponding mentalities seem to be different: they are more competition-oriented, more individualistic and less government-minded. But the topic is far from being neglected in the public discussion within the States. Some years ago, the American catholic bishops edited a pastoral letter entitled: „Economic Justice for All”. (The United States Catholic Conference Inc., 1986) The message was clear: The economic system is not only to be evaluated in terms of efficiency, but also in terms of protection and promotion of human dignity; corresponding to this value, the American economy shows following the pastoral letter - serious deficiencies. The bishop's judgment was: For millions of people living in poverty the American dream of „freedom and justice" is far from being fulfilled; therefore, corrections in the economic and social system are inevitable.

Let us look at Latin America. Among social scientists, the image of this part of the world seems to be quite clear: Latin America's societies are „unjust” in an

Ibero-Amerika Institut für Wirtschaftsforschung der Universität Göttingen, Gosslerstr. 1B, 37073 Göttingen, uwia@gwdg.de 
extreme form; they are fragmented, broken, dualistic; substantial parts of the population - if not the majority - are excluded from political and social life; the distribution of income is extremely unequal; in short: Latin America seems to be the ,unjust society” as such (Mols, Ölschläger, 1997).

As we see, the concept of „social justice” occupies a prominent place in our public and academic discussions. No person who has only a minor sensitivity for public opinion can avoid using this term. Insofar it is "ubiquitous" and „unavoidable".

However, it is a highly cumbersome concept, especially for economists. They have in mind what Hayek told them: „In ... a system in which each individual is allowed to use his knowledge for his own purposes (that is a „liberal system”, governed by the principle of personal freedom, H.S.) the concept of ,social justice" is necessarily empty and meaningless, because nobody can determine the relative incomes in it, or prevent that they be partly dependent on accident. "Social justice" can be given a meaning only in a directed or "command" economy (such as an army) where the individuals are ordered what to do." (Hayek, 1976, p. 69) In other words: Those who ask for „social justice” are asking for an illiberal system, maybe unconsciously. Nevertheless, they move into the direction of totalitarism. Their well-intended strive for "social justice" puts them on "the road to serfdom" (the title of one of the famous books of Hayek, 1944).

Is this an unavoidable consequence? In order to answer this question, we have to clarify the concept of social justice in modern societies. One of their main characteristics, which is relevant in this context, is their structural and institutional differentiation. Among other sub-systems of modern societies we have to distinguish between the political and the economic one. In each of them the term ,justice" has its own meaning. The problem is, that ,justice" in the political field may be undermined by the outcome of ,justice" as it is exercised in the economic sphere. This is the topic of section 2 . The challenge, therefore, is to make the outcome of a ,just" economy compatible with the demand for political justice (section 3). Some measures are adequate in this context (section 4), others are not (section 5). Resulting from this discussion we can draw some conclusions (section 6).

1 Nobelprize winner Hayek summarizes his warnings against the usage of this unavoidable and ubiquitous term "social justice" in the strongest way conceivable: „If political discussion is to become honest it is necessary that people should recognize that the term is intellectually disreputable, the mark of demagogy or cheap journalism which responsible thinkers ought to be ashamed to use." (Hayek, 1976, p. 97). In a kind of personal legacy he continues: „I have come to feel strongly that the greatest service I can still render to my fellow men would be that I could make the speakers and writers among them thoroughly ashamed to employ the term 'social justice' ever again." (Hayek, 1976, p. 97). 


\section{Political and economic interactions: different spheres of ,justice6}

In its most general sense „social justice” relates to all kinds of interactions within society as well as to the results of these interactions. As modern societies are pluralistic in an ideological as well as in a structural sense, they are composed by various networks or spheres of interaction, e.g. the political, economic or religious ones. Each of these networks is being governed by specific rules, each of them has different kinds of organizations, and it is exactly this differentiation which makes the society a „modern" one.

It corresponds to this pluralistic character of modern societies, that also the notion of ,justice" has to be differentiated. There are various ,spheres of justice" as Michael Walzer described the phenomenon (Walzer, 1983). What is the meaning of ,justice" in the sphere of politics, in other words: justice related to everyone's role as a citizen?

Let me answer this question using the words of Rawls who gives the following statement of his „first principle of justice for institutions”: „Each person is to have an equal right to the most extensive total system of equal basic liberties compatible with a similar system of liberty for all." (Rawls, 1971, p. 302).

The emphasis Rawls puts on „equality” in this formulation is striking. Basic liberties should be equal to all, meaning that from an individual point of view each person is to have an equal personal right to these liberties. In fact „equality" is the basic value in Rawls' theory of justice. His first principle already quoted and his second (which I will refer to later) are to be interpreted as special cases of a more general conception of justice that he expresses as follows: „All social values... are to be distributed equally” (Rawls, 1971, p. 62). Rawls makes a restriction to this general conception, but this does not refer to the distribution of basic liberties. They are to be distributed equally without any retrenchment.

Which liberties does he think at? „The basic liberties of citizens are, roughly speaking, political liberty (the right to vote and to be eligible for public office) together with freedom of speech and assembly; liberty of conscience and freedom of thought; freedom of the person along with the right to hold (personal) property; and freedom from arbitrary arrest and seizure as defined by the concept of the rule of law. These liberties are all required to be equal..., since citizens of a just society are to have the same basic rights." (Rawls, 1971, p. 61, italicized by H.S.)

As it is well known, Rawls gives a theoretical foundation for this kind of justice. Under a hypothetical „veil of ignorance", all members of the society should decide upon the basic institutions governing personal interactions and individual positions. In this model of a constitutional process, people supposedly choose this principle of justice. If no one knows neither his own position in 
society nor his own capabilities, he opts for equal rights of liberty which means in a general sense „equal chances for all”.

This theoretical model corresponds to the historical experience of Western societies. „Equal rights for all” was the claim of the French Revolution; postulating that „each person is created equal” and therefore has to be granted the same rights of liberty was the great progress achieved by the founding fathers of the American Constitution; and the „Universal Declaration of Human Rights” (1948) begins with recognizing „equal and inalienable rights” of „all members of the human family". What Rawls re-constructed in a theoretical model corresponds to a large degree to the historical process which culminated in the „Universal Declaration of Human Rights". ${ }^{1}$

So far some remarks on "equality of rights" which is the relevant concept of justice in the sphere of politics. Let me now consider the sphere of economics. Here not equality, but efficiency is the primary goal. Scarce resources are to be allocated in such a way that no good can be produced in a higher amount without reducing the production of some other good; the trade of goods should be allowed to such a degree that no one can increase his „utility" by exchanging goods without decreasing someone else's ,utility". As to all theoretical knowledge and practical experience efficiency in this sense cannot be reached in a command-economy where some central authority decides on what, where and how to produce and controls the trade of goods. The best condition for an efficient economy is to establish the institutions of free markets in which every individual or firm is free to make his own decisions on what, where and how to produce.

In order to avoid any association with the "oikonomia", the self-supporting household, Hayek uses the term „catallaxy” to describe a market economy. Derived from the Greek word „katallatein” which meant not only „to exchange” but also "to admit into community" and "to change from enemy into friend" (Hayek, 1976, p. 108), the term is used to describe the ,special kind of spontaneous order produced by the market through people acting within rules of the law of property, tort and contract" (p. 109). The essential point is that these people do not have a common goal. They strive for quite different aims. There is no central authority which forces them to work for some "common good", and this exactly is the main characteristic of a liberal society.

The best way - following Hayek - to understand the market is to conceive it as a game. It is the "game of catallaxy" (Hayek, 1976, p. 115), essentially a ,positive-sum game" because of its efficiency-improving effect and its quality as a "discovery-procedure". By the spontaneous interaction of the economic players, solutions for many social and economic problems may be discovered. If

This is at least true in respect to Rawls' first principle of justice; referring to the second one - to be discussed later on - the analogy with real evolutions is not so obvious. 
the economy is organized as a "catallaxy-game" it is both efficient and innovative.

Now, which type of , justice" is valid in an economy organized like this? It is the same as in any other game. „Justice" relates to the behavior of players and simply means „keeping the rules”. It does not mean to have claims for certain results. Any game is a good one if its outcome is open. The same must be true for the market-game: Nobody has a guarantee to reach a specific result, e.g. a certain income level. The income earned on the market depends on many factors which are partly or totally outside the individual's control which are, for example, the capabilities of those she is cooperating with, innovations made by competitors, discoveries of new resources, changes of preferences, or pure accident. In sum: Everyone's outcome of participating in the market-game is open.

Therefore, the market cannot offer an equal distribution of results, it cannot offer a specific result at all, neither a „performance-oriented justice”. Someone who makes every effort may not earn enough to survive, the other who works little earns a lot. Our intuition says that this is "unjust". But saying so we measure the market against an „oikonomia”, a command-economy where someone is responsible for the distribution of goods. In the "game of catallaxy" nobody can be made responsible for the distribution of results. Hence, the term „distributive justice” (frequently used as equivalent to „social justice”) does not make any sense. We have to accept this when we opt for a market economy. It offers great advantages, but in cannot offer "distributive justice”.

This may come into conflict with the ideal of justice in the political field. Let me give some examples. Money may buy legal services that can obtain preferred treatment before the law; it may buy influence with elected officials and thus compromises the principle of "one person, one vote". The market with its unequal results may decide on life and death (in many countries e.g. infant mortality rates for the poor are much higher than those for high-income earners). What Okun states for his country is certainly true for any other country: „Some transgression of money on rights make a mockery of America's commitment to civil liberties and democracy. Some of our most cherished rights are auctioned off to the highest bidder. These transgressions may be as important a source of cynicism ... and alienation as the vast disparities in material living standards between rich and poor" (Okun, 1975, p. 30). The frictions between exercising ,just rules" in the economy and guaranteeing, justice" in the political field may get so intensive that the stability of economic as well as political institutions is being threatened. Therefore, something has to be done in order to moderate economic inequalities, in other words, to make the outcome of a ,just economy" compatible with the demand for political justice. Besides this argument for restraining economic inequalities there are some other ones. 


\section{Arguments for moderating economic inequalities}

Distributive inequality may go hand in hand with absolute poverty. In all nations, it corresponds to basic moral principles that the poor should be protected by some re-distributive measures against a life not worthy of a human being. As to this, there seems to be no difference between the moral teachings of the great world religions. Even the most ardent advocates of modern liberalism are in favour of the idea of a minimum-social assistance financed by the wealthy. Let us again take Hayek as an example. Warning against ,social justice", he has no difficulty to pledge at the same time for social aid: „There is no reason why in a free society government should not assure to all protection against severe deprivation in the form of an assured minimum income, or a floor below which nobody need to descend. To enter into such an insurance against extreme misfortune may well be in the interest of all; or it may be felt to be a clear moral duty of all to assist, within the organized community, those who cannot help themselves." (1976, p. 87).

The „assured minimum income" - which for practical purpose has to include basic health services - is not independent from a country's general level of welfare. It should increase, therefore, with the general growth of wealth, because it ,can hardly be denied that, as we grow richer, a minimum of sustenance which the community has always provided for those not able to look after themselves, and which can be provided outside the market, will gradually rise" (Hayek, 1960 , p. 257). Using the terminology of modern literature on poverty, the „poverty line" should move with the average income level.

The important point here is the following: Not all inequalities resulting from the market game are morally tolerated. If these inequalities find their expression in the absolute poverty of some parts of the population, measures which intend to correct them have to be taken.

Re-distributional measures may also be based on a different argument. Following the modern theory of "constitutional economics”, social policy with re-distributional elements may be considered as an „investment" into social capital, which consists of certain institutions in the political and in the economic field. These institutions can only function if they are accepted by all members of society (Homann/Pies, 1996). Especially the institutions of the market-game have to be tolerated by those who are going to lose in this game. Offering them a "safety-net" will help them to accept the rules. In other words: some kind of redistribution may be considered as a ,premium for tolerance"; in the constitutional process people are paid in order to make them "tolerant" towards economic institutions which typically lead to inequalities. By means of redistributive policies the whole institutional setting of a society may be 
considered ,just" or "fair" because it is accepted by the public. ${ }^{1}$ In this reasoning social policy with re-distributive elements is not a "grant" which can be withdrawn if resources are getting scarcer. It is an ,investment" which cannot be cancelled if a country's institutional framework is to be maintained.

This argument can be applied more specifically to a market-game itself. Players in the game need some flexibility and they have to bear some risks. Being „insured" in a general sense against severe poverty makes people more willing to take risks and to leave traditional positions. In other words, being protected against poverty can contribute to a higher structural flexibility and to higher rates of investments and innovations. Social policy must not be pushed through "against" the market, but it can be applied „in favor" of the market. The following metaphorical expression can illustrate this point: Social policy with re-distributive elements is not a "hammock" in which people relax, but a "safety-net" which mobilizes the talents of trapeze artists in the circus (Kleinhenz, 1992, p. 52). It goes without saying that this function depends on the specific form of social distributional measures. Certain forms may easily be used as „hammocks” (see section 5).

It is of special importance in this context to reach some equality in the distribution of income generating assets (land, physical capital, human capital). The empirical studies of Tabellini (1994), Perotti (1992), Deininger/Squire (1997), Squire (1999) and some others stress this point. They showed a positive relationship between economic growth-rates and distributive equality, and one of the explanations given by these authors is the following: Given a low incomeconcentration, there is no pressure for social policy measures which could reduce economic growth-rates. This implicitly means that some equality should be reached on the level of assets-distribution which allows every part of the labor force to participate with relative high labor productivities in the process of income generation. Squire stresses this point explicitly: Equal distribution of land (c.p.) has a positive effect on growth-rates.

So far we got to know a moral and a constitutional-economic argument for moderating economic inequalities. It is interesting how Rawls, following a different approach, also gets the result that social and economic inequalities should be restricted. They may be considered as "fair" or ,just" only in case they fulfill a social function. This is the content of his "second principle of justice”, the „difference principle” as he calls it: „Social and economic inequalities are to be arranged so that they are both (a) to the greatest benefit of the least advantaged and (b) attached to offices and positions open to all under

1 „Fairness" or ,justice" of an institution can be defined - following Buchanan - by its acceptance. „A „fair rule" is one that is agreed to by the players in advance of play itself, before the particularized positions of the players come to be identified. Note carefully what this definition says: a rule is fair if players agree to it. It does not say that players agree because a rule is fair. That is to say, fairness is defined by agreement, agreement does not converge at some objectively determined fairness." Buchanan, 1986, p. 126. 
conditions to fair equality of opportunity" (Rawls, 1971, p.83). For example, the stock of physical capital may be distributed in a very unequal way. However, the entrepreneur who owns a large amount of capital may be motivated to create new products and to open new production lines thus offering jobs to unskilled workers. In other words: Inequality has a social function. It ought to stimulate activities which can improve the situation of the poor. Those inequalities which do not fulfill this function are not „fair". Rawls is very rigorous in this context: „Those who have been favored by nature, whoever they are, may gain from their good fortune only on terms that improve the situation of those who have lost out. The naturally advantaged are not to gain merely because they are more gifted, but only to cover the costs of training and education and for using their endowments in ways that help the less-fortunate as well. No one deserves his greater natural capacity nor merits a more favorable starting place in society. There is another way to deal with them. The basic structure can be arranged so that these contingencies work for the good of the least fortunate." (Rawls, 1971, p. 101f.)

The second part of this „difference principle" refers to ,equality of opportunity”. Every society is structured in a hierarchical way. Positions and offices are unequal. This is just a functional necessity. However, difficult positions should be given to the most capable, and everyone should have a fair chance to compete for higher positions. Discrimination should not be allowed.

Following Rawls, people will opt for this ,second principle of justice” as well as for the first one as long as they are ignorant as to their own position at present and in the future. They will opt for ,equal opportunities" and for the acceptance of inequalities insofar as both fulfill a social function. This „difference principle" does not correspond as obviously to reality as Rawls' first principle does. However, considering the political programs of many countries it seems not completely mistaken to assume the following: The degree of social and economic inequality is accepted; severe poverty, however, is not; neither any form of discrimination which makes „equal opportunities” impossible.

Having discussed, now, some aspects of justice, we may summarize the last two sections. „Justice" referring to the position and interaction of persons within society means different things for different spheres of the social system. In politics, it basically means ,equal liberty rights for all”. In the economic system, organized in a competitive way, it stands for "keeping the rules the market game". However, this kind of behavioral justice in the economy may lead to social and economic inequalities which undermine the equality of liberty rights, which violate moral principles and weaken the stability of institutional arrangements in politics as well as in the market economy. Something, therefore, should be done in order to moderate these inequalities and to give them a social function. "Social justice", therefore, may be considered as that distributional pattern of assets and income which supports „equal rights" and stabilizes the 
institutions of a free society part of which is the competitively organized economic system.

The decisive question is, how the destabilizing consequences of economic inequalities, that are considered as immoral, can be avoided without suspending the competition rules which (at least partly) generate these inequalities. It is a question of „how to do", not the question "should it be done ". Every society must find some solution for the problem that practising the rules of the market game might lead to some consequences which make these rules less reliable and less efficient. In Germany, the solution has been named „social market economy"; Rösner gives some details on the corresponding institutional arrangements (see Chapter 3 in this volume). In other countries the labels are different. The basic challenge, however, is the same, and it is not easy to find an adequate answer and to avoid an inadequate one.

\section{Some measures to implement ,social justice" in a market economy}

It is self-evident that priority should be given to the initiatives of individuals and social groups. In other words: every instrument of re-distribution and social policy should respect the criterion of "subsidiarity". It should also respect a second criterion: interference with the market rules should be avoided as far as possible. There is a substantial scope for measures which correspond to this criterion. The following contributions in this volume will discuss some of them in detail. In this section only some general possibilities shall be presented: (a) the protection of equal rights, (b) the improved access to human capital formation, (c) public activities in the field of social insurance.

(a) Protection of equal rights. - Civil as well as economic human rights can be violated by an unequal distribution of wealth, as we have seen and - as we can add - by political authorities not disciplined by constitutional rules and susceptible to the pressure of private interest groups. Small-scale farmers for example may not find the needed legal protection for their property in case of conflict with big land owners; minority groups are excluded from certain economic activities and from the political process; workers may not be allowed to form and to join coalitions - one of the basic principles accepted by nearly all nations when they signed the „International Covenant of Economic, Social and Cultural Rights". In numerous cases this covenant has been violated.

Therefore, an elementary contribution to implement ,social justice” is to secure an impartial protection of civil and economic rights. Even the most libertarian social scientists would agree with this. Nozick (1974) is an example. In his „minimal state" the government offers „legal protection” as a kind of ,public good" to everyone. However, in the practice of many states, this minimum of governmental action is far from being fulfilled. Materializing „social justice”, 
therefore, urgently needs political action. Meanwhile this is recognized as a basic target of development cooperation. In a paper, published by the „German Ministry Development Cooperation" the ,protection of all human rights” within a reliable legal system is stated as "common goal" of industrialized and developing nations (BMZ, 1998, p.7).

The way to reach this goal includes various steps which can be ordered in a hierarchical way: the state gets a ,power-monopoly" within the country - it establishes individual liberty rights - it guarantees the right to form coalitions it tolerates a critical public - it promotes and protects participatory institutions its actions are restricted by constitutional rules and controlled by an independent judiciary (BMZ, 1992, p.10ff.). In short: the establishment and protection of equal rights needs a legal state and - as we may add - ,good governance”. This will contribute to ,social justice" without any violation of market rules. On the contrary: these rules are the more reliable the better individual rights are protected.

(b) Improved access to human capital formation. - A high income concentration combined with wide-spread poverty usually reflects an unequal distribution of assets, the most important of which is „human capital”. The challenge, therefore, is to make the chances more equal to participate in the process of human capital-formation.

The relevant arguments are discussed in the contribution of Gerlach (see Chapter 4): The rate of return to education is positive and it is higher for students from low-income families than for those from a high-income background. Therefore, improving the educational chances of the poor contributes to „social justice”. At the same time it stimulates economic growth. An educational policy, therefore, which equalizes the chances in the process of human capital-formation harmonizes ,equity” with ,growth”.

In its 1998-1999 „Report on Economic and Social Progress in Latin America”, the Inter-American Development Bank gives some details on educational inequalities in Latin American countries and the relevant measures of educational policy. For children from poor households (defined as households in the lower 40 percent in terms of consumption and standard of living (IDB, 1998, p.48)), the chances to complete primary education and to get a higher education are much lower than those for children from a wealthy background (defined as households in the upper 20 percent). Whereas on average 94 percent of the children in the first category in the South American countries considered (Bolivia, Brazil, Colombia and Peru) enroll in the first year of primary education, only 63 percent complete the $5^{\text {th }}$ and 15 percent the $9^{\text {th }}$ year. By contrast, in the second category, 93 percent of the children finish their $5^{\text {th }}$ year of school and 58 percent their $9^{\text {th }}$ year (IDB, 1998, p.49). The problem, therefore, is not an unequal access to the educational system (which differs Latin America from Africa), but the high dropout rates among the poor. The problem is 
aggravated by the quality-gap between public schools (which are mainly attended by children from poor families) and private schools (predominantly attended by children from the rich; IDB, 1998, p.54).

Given the average rates of return for different educational levels, the incomeratio between an individual with a complete university education and an uneducated worker is eight to one for Latin America as a whole (IDB, 1998, p.52). This income gap resulting from educational inequalities is replicated and amplified within the families, as the number of children is largely dependent on the mother's income generation potential and an increasing size of family worsens the chances to get a higher education.

In order to break the vicious circle between educational inequalities and high income concentration, the chances of children from a low-income background should be improved to get a qualified primary education and to reach higher educational levels. This is a financial issue, but it is also an organizational one.

For poor families, direct costs as well as the opportunity costs of sending children to school are relative high. These costs can be reduced by cash subsidies or by providing textbooks, school uniforms and transportation. School nutrition programs are another measure to stimulate the demand of poor families for regular and higher education. By using voucher programs, the scope of these families to make a choice between different schools can be amplified. If financed by taxes on income and wealth with progressive tax-rates, these measures are equivalent to an income-re-distribution. Supplemented by organizational reforms which give schools more autonomy, improve the transparency of the educational process and strengthen the right of parents, this re-distribution will not only stimulate growth, but also stabilize the institutional framework of democracy and of market systems, in other words: ,justice" in the economic sphere becomes more compatible with political justice.

(c) Public activities in the field of social insurance. - In section 3, an argument based on the modern theory of constitutional economics was presented. Social policy may be considered a "safety net" which encourages risky investments with high rates of return and helps to make the rules of competition more acceptable. One cannot expect that these functions are being fulfilled by market-systems alone even though competition may play a more important role as sometimes is acknowledged. In the context of social insurance we have typical forms of weaknesses and failures of private markets. Services may be delivered with increasing returns to scale, external effects may distort the result of markets, some services may be considered public or merit goods, asymmetric information can lead to adverse selection and to the breakdown of markets etc. (Barr, 1992). In every country, therefore, governments regulate in one way or the other insurance schemes which cover health risks, the risk of a substantial income reduction caused by unemployment, the risk of old-age 
poverty etc., and nearly all these schemes include some elements of income-redistribution.

The following contributions in this volume give an impression of the big variety of possible solutions and they discuss the respective advantages and disadvantages. As will be shown, several models are compatible with a market system, and which of them is practicable depends to a large degree on the effectiveness of public administration, the educational level and the cultural tradition of a country. There is no blueprint which could be transferred to every country.

This also holds true for Latin America. There are, however, some common problems for which solutions have to be found. One of them is the low coverage rate of the poor in social insurance schemes. In general, these schemes favor those who are employed in the formal sector, who are well trained and who earn wages well above the minimum wage-level (Mesa-Lago, 1991, Sautter/Schinke, 1996). In other words: social insurance protects those in a privileged position; the most vulnerable individuals are excluded (IDB, 1998, p.147). From this follows a second problem: the regressive distributional effect. The concentration of market incomes is aggravated, not moderated, by social insurance systems (IDB, 1998, p.149).

Taking serious the above mentioned argument based on the theory of constitutional economics, the ongoing social policy reforms in Latin America, therefore, have to be supplemented by a re-distributive element. These reforms tend to encourage self-help and to strengthen the link between contributions and benefits; but they are neither consequent enough in eliminating the inherent regressive distributional elements in traditional insurance systems nor do they expressively introduce re-distributive elements. Making insurance schemes more market-oriented, as currently is done, the challenge should not be neglected to make ,justice" as it is understood in the economic field more compatible with ,justice" as it is promised in the political sphere.

There are possibilities to do this without suspending the market rules: guaranteed minimum incomes by a social transfer-system, minimum pensions, sufficiently funded health-care systems accessible for the poor - to mention only a few examples. Elements like these do exist; what matters is to strengthen them.

The question underlying this section was: Which are the adequate measures to implement „social justice" in a market economy, the term being defined as that distributional pattern of assets and income stabilizes the institutions of a democratic society. Summarizing, we come to the conclusion that - besides the protection of individual liberty and property rights - improving the chances of the poor in the process of human capital formation, extending the coverage of social insurance schemes and introducing some re-distributive components into 
these schemes are some of the relevant measures. They are "adequate" in the sense of being compatible with the rules of the market game. Those who want to strengthen these rules are not hindered to accept these measures. What is not acceptable, however, from an economic point of view is applying inadequate measures.

\section{Policies to be avoided}

It may be tempting to change the rules of a game in order to get a certain outcome. This can be done once or twice; then the game will cease. What makes it interesting, namely its open result, has been destroyed. This is also true for the "market game". Manipulating the rules of the market - those of free competition - will diminish its positive effects. In case of repetition, the market breaks down.

This argument may be accepted on a theoretical level in which the society's general interest plays the decisive role. The problem is that each economic actor has his particular interests, and this can be realized, indeed, by suspending the rules of competition. Of course, it is not advisable to ask for such an intervention in the name of some particular purpose. The chances to change the rules are better if it can be shown that the change will help some "common purpose". More specifically: The best way to suspend competition rules in someone's own interest seems to be to demonstrate that the suspension is associated with more „social justice”. In this context the term means „distributive justice” or ,justice of results", which as we already know cannot be brought about in a market system. But the term has much political appeal, and thus is commonly used to make particular interests more acceptable.

The outcome of any manipulation of the market rules in the name of ,social justice" is obvious. The innovative dynamism and the efficiency of the market system suffers. The general public has to pay the price for these interventions, supposedly for the sake of ,social justice”, in reality in some groups' particular interest. Therefore, measures which intend to redistribute or protect incomes of particular groups by suspending the rules of competition should be avoided. They are not suitable for moderating economic and social inequalities.

The argument may be illustrated by some examples. The first relates to technical progress. Following Schumpeter, technical progress has always the character of „creative destruction”. Old products and production facilities are replaced; they are „destroyed" in an economic sense, and frequently also in a physical sense. Jobs are being eliminated, and from the perspective of people who loose their source of income and who cannot be re-trained, this is an "unjust" event brought about by the competition process. If workers threatened by unemployment are organized well enough, they can press to political authorities for introducing some protective measures. One of them may be to subject every innovation to a test of ,social compatibility”, whereby this test is considered to have failed in case of unemployment effects. The public has to pay 
the price in form of the foregone „social surplus” which could be brought about by such innovations. The government which applies such a test of "social compatibility" can do so in the name of "social justice" which really means „income protection for a particular group of workers". By suspending competition rules the real "social effect" is, of course, a negative one.

Let me mention a second example: Domestic jobs are being threatened by international competition. These jobs can be protected by introducing tariffs or non-tariff-barriers against imports. This is an obvious violation of the marketrules laid down in the "General Agreement on Tariffs and Trade". However, countries always find some ways to bypass these rules. Sometimes, the workers and entrepreneurs who benefit from these measures can convince the public that this policy corresponds to ,social justice". In reality it is a domestic redistribution of real incomes from consumers to producers (and possibly to the state), accompanied by a net welfare loss for the home country and a welfare loss for more competitive foreign countries.

There are many other examples which are not so obvious as those already mentioned. Sometimes the protective and redistributive motivations are complemented by others, e.g. intentions to correct market failures. In many cases it is not easy to distinguish between efficiency-improving and mere distributive effects. Without going into detail and without trying to make an evaluation, I will introduce some measures which play a prominent role in the ongoing discussion about the "mis-directed welfare-policy" in industrialized countries:

- Tenants of apartments are protected against an „unjustified" notice to quit (one of the consequences may be an unsatisfied demand for flats);

- Workers are protected against „unjustified” dismissal (employers hesitate to engage new workers);

- Farmers are protected against income losses through price-interventions and production-augmenting subsidies (domestic consumers and farmers in export countries bear the costs);

- High taxes and social contributions distort the signals of the labor market (factor supply moves to the shadow-economy causing diseconomies to scale);

- Wages for low-skilled labor are set above competition-level (possibly lowskilled workers cannot be employed).

In cases like these, competition on factor- and product markets is distorted, prices are manipulated, which leads to losses of efficiency and innovative power. From truly „social” point of view these measures should be avoided. There are better instruments to moderate income inequalities, as was shown in the last section. 


\section{Conclusions}

At the beginning Hayek's fierce protest against using the term „social justice” was mentioned. Following his criticism, every attempt to materialize this ideal will open a „road to serfdom”. „Is this an unavoidable consequence?” was the question raised.

Not at all. It is true that economic justice in the sense of „keeping the market rules" will generate unequal results which can undermine ,justice" in the sphere of politics defined as „equality of individual rights". But there are adequate means to moderate these inequalities and, therefore, economic justice can be made compatible with the political one. In other words: „Social justice” in the sense of an acceptable distributional pattern can be implemented without suspending the rules of a free society and a market system. On the contrary: Moderating distributional inequalities can strengthen and stabilize these rules. However, it is easy to use inadequate distributional measures which come into conflict with competition rules.

Every country is confronted with a specific challenge to find adequate measures and to avoid inadequate ones. For industrialized nations with their rich welfare-state tradition the challenge is a different one from that of semiindustrialized or developing countries. On one hand the task is to make welfare-institutions more compatible with a market-game in order to give them their innovative function. On the other hand the acceptance of the rules of the market-game has to be secured by intelligent safety-nets; „intelligent” in the sense of ,promoting innovations", avoiding the „hammock-fallacies".

Let me state a few main points on the challenges for a European country like Germany. Here

- people who are able to do so have to bear a higher amount of risk, thereby restoring the proper function of social insurance systems which never have been thought of as a substitute for private providence.

- Workers and entrepreneurs as well have to learn again that ,innovation” means „creative destruction" and that every progress pre-supposes the willingness to leave old positions.

- Owners of productive resources have to adjust their expectations and their actions to the rules of world-wide competition because the "game of catallaxy" cannot be played successfully if it is confined to the one nation or a regional group of nations.

Latin American countries seem to be confronted with some other priorities. These countries should (among other tasks)

- establish a non-corrupt legal system in order to materialize the promise of „equal liberty rights for all" which is the content of ,justice" in the political sphere; 
- improve the educational system in order to give substance to the promised ,justice of opportunity";

- reform social insurance systems so that they lose their regressive character and protect those who are truly in need;

- establish a safety-net for those who cannot make their living.

Implementing ,justice" in a society needs different instruments in correspondence to a country's specific situation. But the task is indeferrable, because ,justice" is the foundation of every civilized nation. 


\section{References}

BARR, N. (1992)

Economic Theory and the Welfare State: A Survey and Interpretation, „The Journal of Economic Literature", Vol. XXX, June 1992, No. 2, pp. 741-803.

BMZ (BUNDESMINISTERIUM FÜR WIRTSCHAFTLICHE ZUSAMMENARBEIT UND ENTWICKLUNG) (1998)

Förderung der Menschenrechte, eine Aufgabe der Entwicklungszusammenarbeit, BMZ aktuell 090, Bonn.

BMZ (BUNDESMINISTERIUM FÜR WIRTSCHAFTLICHE ZUSAMMENARBEIT UND ENTWICKLUNG) (1992)

Grundsätze und Schwerpunkte der deutschen Entwicklungszusammenarbeit in den 90er Jahren. Wissenschaftlicher Beirat beim Bundesminister für wirtschaftliche Zusammenarbeit, München usw.

BUCHANAN, J.M. (1986)

Liberty, Market and State. Political Economy in the 1980s, Brighton.

DEININGER, K. / SQUIRE, L. (1997)

Economic Growth and Income Inequality: Reexamining the Links. „Finance and Development", March, 97, pp. 38-41.

HAYEK, F.A. (1960)

The Constitution of Liberty, London.

HAYEk, F.A. (1976)

Law, Legislation and Liberty, Vol. II: The Mirage of Social Justice, London and Henley.

HAYEK, F.A. (1944)

The Road to Serfdom, London.

HOMANN, K. / PIES, I. (1996)

Sozialpolitik für den Markt: Theoretische Perspektiven konstitutioneller Ökonomik, in: Pies, I.; Leschke, M. (Hrsg.): James Buchanan's konstitutionelle Ökonomik, Tübingen, 1996, S. 203-239.

IDB (INTER-AMERICAN DEVELOPMENT BANK) (1998)

Facing up to Inequality in Latin America, Economic and Social Progress in Latin America, 1988-1999 Report, Washington D.C.

KLEINHENZ, G. (1992)

Die Zukunft des Sozialstaats. Spielraum für sozialen Fortschritt unter veränderten Rahmenbedingungen, in: Hamburger Jahrbuch für Wirtschafts- und Gesellschaftspolitik 37, S. 43-71.

MESA-LAGO, C. (1991)

Social Security in Latin America, in: Inter-American Development Bank, 
Economic and Social Progress in Latin America, 1991 Report, Washington D.C., pp. 179-215.

MOLS, M. / ÖLSCHLÄGER, R. (1997)

Lateinamerika: die ungerechte Gesellschaft, Stuttgart.

NOZICK, R. (1974)

Anarchy, State, and Utopia, Oxford.

OKUN, M. (1975)

Equality and Efficiency, The Big Tradeoff. Washington.

PEROTTI, R. (1992)

Income Distribution, Politics and Growth, „The American Economic Review”, papers and proceedings, Vol. 82, No. 2, May 1992, p. 311-316.

RAWLS, J. (1971) A Theory of Justice, Oxford etc.

SAUTTER, H. / SCHINKE, R. (1996)

The Social Dimension of the Latin American Reform Process, in: Sautter, H.; Schinke, R. (Eds.) (1996): Stabilization and Reforms in Latin America: Where do we stand? Frankfurt/M., S. 207-241.

SQUIRE, L. (1999)

Einkommensverteilung und Wirtschaftswachstum, in: Schubert, R. (Hrsg.) (1999): Neue Wachstums- und Außenhandelstheorie, Berlin, S. 157-176.

TABELLINI, G. / PERSSON, T. (1994)

Is Inequality Harmful for Growth? „The American Economic Review”, Vol. 84, No. 3, June 1994, p. 600-621.

THE UNITED STATE CATHOLIC CONFERENCE, INC. (1986)

Economic Justice for All: Catholic Social Teaching and the U.S. Economy (German translation: Wirtschaftliche Gerechtigkeit für alle, Sonderausgabe der Zeitschrift „Die neue Ordnung”, hrsg. vom Institut für Gesellschaftswissenschaften, Walberg, 1987).

WALZER, M. (1983)

Spheres of Justice. A Defense of Pluralism and Equality, New York. 


\title{
Indicators of Social Justice in Latin America: \\ A Matter of Concern?
}

\author{
Rolf Schinke*
}

\section{Introduction}

„Latin American societies are unjust in an extreme form; ... the distribution of income is extremely unequal... (Sautter, this volume, p. 1) and one may add that absolute poverty is relatively high. The aim of this paper is to give some empirical substance to these assertions, to analyze some of the causes and to discuss their possible consequences.

How can one determine empirically and what indicators do adequately reflect „social justice"? Recalling the results of the first session of this summer school we face a serious problem: We do not really know the exact meaning of social justice. All we know is that deviations cannot be tolerated when they become too large. But what are the deviations that are allowed? This is an unsolved question and it is not intended here to solve it.

The aim of this paper is more limited. What will be done is to describe the situation as it is found in different parts of the world using indicators that are usually tied to social justice: indicators of the distribution of income and of poverty prevailing in the countries to be observed. Admittedly, this is not a completely satisfying way of analysis. What can be said in its favor is its pragmatism.

Thus, I will look at absolute and relative income levels: absolute in the sense of looking at those whose income falls short of a certain specified level, usually defined as the poverty line and relative in the sense of analyzing the distribution of income within the countries or groups of countries concerned. Specifically, it will be asked if the distribution of income is relatively unequal or the levels of poverty are relatively high compared with countries that have a similar level of per capita income. This will be done in section 2. Next I will look at the causes of inequality and poverty (section 3) and its consequences (section 4). A summary is given in section 5 .

- Ibero-Amerika Institut für Wirtschaftsforschung der Universität Göttingen, Gosslerstr. 1B, 37073 Göttingen, uwia@gwdg.de 


\section{Indicators of social justice}

From Hermann Sautter's contribution in this volume one may conclude that the term „social justice" can be reduced to the notions of ,equal rights" in the political and to „equal rules" in the economic sphere provided a) that poverty is avoided defined as income including transfers that is insufficient to cover the expenses defined by the poverty line and $b$ ) that deviations from a socially accepted situation of the income distribution do not lead to disturbances of the market process and to less efficiency of the economic system. For those whose task is to illustrate indicators of social justice this definition is not extremely helpful. What is the socially accepted assured minimum income and what is the deviation from equality that is justified? The problem we face is that we do not know neither the exact range of the deviations that can be tolerated socially nor the border-line that forces politicians to initiate policy measures to reduce inequality and poverty. Therefore, much depends on value judgements of researchers or politicians or on conventions. A clearer picture is given of what social justice is not meant to be in market economies: an equal distribution of the results of the play of market forces. Nevertheless, economists typically use indicators of inequality and thus of lack of social justice that utilize equality as base for their measuring rod, i.e. the deviation of the outcome of the play of market forces from an equal distribution.

With these problems in mind a rather pragmatic position will be taken in this paper. A country's situation will be regarded as socially unjust if its indicators of social justice are substantially higher than those of other countries with a comparable income per capita. The indicators used in this analysis are the Gini coefficient as a comprehensive measure of the distribution and the headcount index as indicators for the non-fulfillment of the minimum assured income requirement. This procedure can be justified when a rather strong association exists between the respective indicators and per capita income. As will be explained later this is not an easy task. With respect to the distribution of income there are nearly as many studies refuting this hypothesis as are in favor of it. The situation is even worse with respect to poverty. All we know is that there is an asymmetric association between poverty and income: poverty moderately declines in times when incomes are rising (Fields, 1989) while it strongly increases when incomes are falling (de Janvry/Sadoulet, 1996).

\subsection{Income distribution}

The inequality of income distribution is usually illustrated with the aid of the 'Lorenz curve', which indicates what percentage of the population receives what percentage of income. Figure 1 shows that the Lorenz curve for Brazil in 1987 (plotted in bold) deviates further from the straight line of equal distribution than the Lorenz curves for Costa Rica in 1986 and Korea in 1988: Brazil shows a higher level of income inequality than Costa Rica and both have more unequal distributions than Korea. For reasons of data availability I will use the 'Gini 
coefficient' as a concise measure of inequality despite its well-known deficiencies. This coefficient is obtained as the percentage proportion of the area between the straight line of equal distribution and the Lorenz curve $A$ and the whole area below the straight line of equal distribution (A+B in Fig. 1).

\section{Figure 1: Lorenz curves for Brazil, Costa Rica, and Korea}
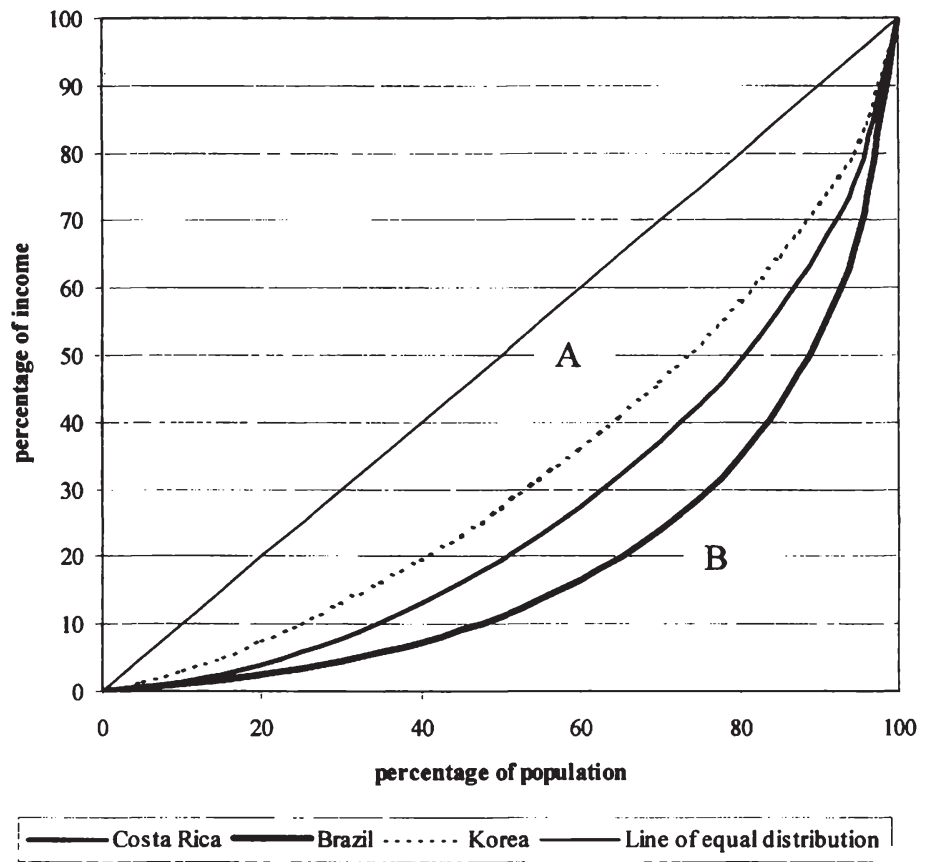

Data: Deininger/Squire (1996)

A serious problem associated with this measure of inequality is its inability to distinguish between distributions whose coefficient is roughly similar, but whose Lorenz curves intersect. Further, the Gini coefficient is insensitive to changes in income at the upper and lower end of the income distribution (Lüthi, 1981). Other measures of distribution such as quintile ratios (e.g. the ratio of the fifth to the first quintile), the income share of the first two quintiles, share the problem of using only a part of the information available. Theil's entropy measure is rarely used in the case of developing countries. The statistical association between these substitute measures and the Gini coefficient is regularly strong (Schinke, 1998). 
It is often stated that income distribution in Latin America is unequal to a high degree. Before any conclusions can be drawn the reference standard must be understood. Of course, this cannot be the equal distribution of all incomes, compared with which every empirically ascertainable income distribution is unequal. The income distribution of a country (region) will therefore be described as unequal if, on a comparison with countries in the same region (other regions) or with countries (regions) at a comparable level of development, it is characterized by a comparatively high Gini coefficient.

According to these criteria, the income distribution of Latin America as a region and its countries must be described as relatively unequal. ${ }^{1}$ Table 1 shows details of regional changes over the last four decades. Over the whole period and in each individual decade, of all regional groupings Latin America has the highest average value of the Gini coefficient, which after a slight fall between the 1960s and the 1970s has remained almost constant, whereas it has been falling in the Asian region since the $1960 \mathrm{~s}^{2}$

According to these criteria, the income distribution of Latin America as a region and its countries must be described as relatively unequal. ${ }^{3}$ Table 1 shows details of regional changes over the last four decades. Over the whole period and in each individual decade, of all regional groupings Latin America has the highest average value of the Gini coefficient, which after a slight fall between the 1960s

1 In the example above the respective Gini coefficients are $57 \%$ for Brazil, $42 \%$ for Costa Rica and $34 \%$ for Korea. Thus, income distribution in Korea is less unequal than that in Costa Rica which in turn is less unequal than that in Brazil.

2 The same result is obtained from quintile measures. With the exception of the $1960 \mathrm{~s}$, when the Sub-Saharan African countries disputed the lowest ranking with Latin America, measured in terms of the income shares of the individual quintiles Latin America had the worst values (Deininger/Squire, 1996). In the period average from the 1960s to the 1990s the first (lowest) quintile had an income share of less than four percent (and thus less than half of that of the Eastern European countries), whereas the top quintile had a share of 55 percent. Nevertheless, from decade to decade the group of the top 20 percent of income earners has a lower income share: it falls from just under 62 percent in the 1960s more or less continuously to 53 percent in the 1990 s and thus comes very close to the value for the African countries $(52.37 \%)$. In all other regions the share of the upper twenty percent of the population is considerably lower; it fluctuates between 45 and 36 percent. In this respect as well, the Eastern European countries occupy a special position; their share is the lowest and falls until into the 1980s, but subsequently rises considerably in the 1990s $(+9.1 \%)$.

3 In the example above the respective Gini coefficients are $57 \%$ for Brazil, $42 \%$ for Costa Rica and 34\% for Korea. Thus, income distribution in Korea is less unequal than that in Costa Rica which in turn is less unequal than that in Brazil. 
and the 1970s has remained almost constant, whereas it has been falling in the Asian region since the 1960 s. $^{1}$

Table 1: Decade averages of the regional Gini coefficients

\begin{tabular}{|l|c|c|c|c|c|}
\hline \multirow{2}{*}{ Region } & \multicolumn{5}{|c|}{ Average over } \\
\cline { 2 - 6 } & $\begin{array}{c}\text { all } \\
\text { decades }\end{array}$ & $1960 \mathrm{~s}$ & $\mathbf{1 9 7 0 s}$ & $\mathbf{1 9 8 0 s}$ & $1990 \mathrm{~s}$ \\
\hline Latin America and the Caribbean & 49.78 & 53.24 & 49.06 & 49.75 & 49.31 \\
\hline Sub-Saharan Africa & 46.05 & 49.90 & 48.19 & 43.46 & 46.95 \\
\hline Middle East and North Africa & 40.49 & 41.39 & 41.93 & 40.45 & 38.03 \\
\hline Eastern Asia and the Pacific & 38.75 & 37.43 & 39.88 & 38.70 & 38.09 \\
\hline Southern Asia & 35.08 & 36.23 & 33.95 & 35.01 & 31.88 \\
\hline $\begin{array}{l}\text { Industrialized and developing } \\
\text { Countries with high income }\end{array}$ & 34.31 & 35.03 & 34.76 & 33.23 & 33.75 \\
\hline Eastern Europe & 25.57 & 25.09 & 24.63 & 25.01 & 28.94 \\
\hline
\end{tabular}

Source: K. Deininger/L. Squire (1996), p. 584

The marked regional inequality of income distribution in Latin America is not due to the fact that a few individual countries have a particularly high Gini coefficient. It is rather the case that in this subcontinent many countries have a comparatively high Gini coefficient. This becomes particularly clear from the following comparisons on the basis of Tables 1 and 2 .

- The lowest average Gini coefficient of a Latin American country (Bolivia with a coefficient of $42 \%$ ) is higher than the mean value of all other world regions with the exception of Africa.

1 The same result is obtained from quintile measures. With the exception of the $1960 \mathrm{~s}$, when the Sub-Saharan African countries disputed the lowest ranking with Latin America, measured in terms of the income shares of the individual quintiles Latin America had the worst values (Deininger/Squire, 1996). In the period average from the 1960s to the 1990s the first (lowest) quintile had an income share of less than four percent (and thus less than half of that of the Eastern European countries), whereas the top quintile had a share of 55 percent. Nevertheless, from decade to decade the group of the top 20 percent of income earners has a lower income share: it falls from just under 62 percent in the 1960s more or less continuously to 53 percent in the 1990 s and thus comes very close to the value for the African countries $(52.37 \%)$. In all other regions the share of the upper twenty percent of the population is considerably lower; it fluctuates between 45 and 36 percent. In this respect as well, the Eastern European countries occupy a special position; their share is the lowest and falls until into the $1980 \mathrm{~s}$, but subsequently rises considerably in the $1990 \mathrm{~s}$ $(+9.1 \%)$. 
- The lowest annual value of the Gini coefficient of a Latin American country (Venezuela, 39.4\%) is still almost as high as the regional average over all decades in the Middle East and North Africa (40.5\%) and in some cases considerably higher than the average value for Asian regions;

- The maximum Gini coefficient in Latin America (Brazil, 61.9\%) is only exceeded worldwide by the maximum values for Gabon (63.2\%) and South Africa (62.3\%), and the highest average value for a country in Latin America (Brazil, 57.3\%) is only exceeded by Gabon.

- Compared with the countries of Eastern Asia, which have a similarly high per capita income, the countries of Latin America show clearly higher Gini coefficients.

Despite the overall high level of the Gini coefficients of Latin American countries, there are still considerable differences between them. Table 2 clarifies this. In this table the countries are classified according to their average Gini coefficient from the 1960s to the 1990s (column 1). As table 2 shows, the range of the average Gini coefficients for individual countries - about 15 percentage points - is considerable; in this respect this subcontinent is only exceeded by the Sub-Saharan African countries (Deininger/Squire, 1996). The country showing the greatest income inequality in Latin America is Brazil, whose average Gini coefficient is 57 percent. The Latin American leader in equality of income distribution is Bolivia, which is however only represented with one observation in the list, with a Gini of $42 \%$. Disregarding the African countries, the set of data provided by Deininger/Squire only shows five countries in the remaining world regions whose average income distribution is worse than the best in Latin America. From the countries in the Middle East and North Africa, these are Iran and Tunisia, and from the group of industrialized and developing countries with a high income, these are the Bahamas, France and Turkey. None of the Asian and Eastern European countries shows a Gini coefficient which is higher than that of Bolivia.

Columns 3 and 5 in Table 2, which indicate the minimum and maximum Gini coefficient for each country, show that even within the individual Latin American countries including the Caribbean, the Gini coefficients fluctuate considerably over the course of time. Accordingly, the least unequal, measured in terms of income distribution, is Jamaica (a country not necessarily typical for Latin America), with a Gini of 38 percent and the most unequal is Brazil with a Gini of almost 62 percent. The minimum value for Brazil (53\%) is still considerably above the Latin American average (50\%), and even in the column of maximum values, the minimum value for Brazil would be still in 11th position. The persistent unequal income distribution in Brazil is evident not only in the

1 The average Gini coefficient for Latin America over the whole period is entered on the first line. This average value deviates from that in Table 1 because there unadjusted raw data were used to calculate the average 
relatively high extreme values of its Gini coefficient, but also in the latter's relatively slight standard deviation over the period recorded by Deininger/Squire. Since Brazil accounts for around 35 percent of the whole population of Latin America, its inequality would characterize that of Latin America to a considerable extent if in Table 1 the averages weighted with the respective population shares had been used instead of the unweighted mean values.

Table 2: Income distribution in Latin American and Caribbean countries

\begin{tabular}{|l|l|r|r|r|r|r|r|r|r|r|}
\hline $\begin{array}{l}\text { Region/ } \\
\text { country }\end{array}$ & $\begin{array}{c}\text { Gini } \\
\text { average }\end{array}$ & Rank & $\begin{array}{l}\text { Gini } \\
\text { min. }\end{array}$ & Rank & $\begin{array}{c}\text { Gini } \\
\text { max. }\end{array}$ & Rank & $\begin{array}{c}\text { Std. } \\
\text { devia- } \\
\text { tion }\end{array}$ & Rank & $\begin{array}{c}\mathbf{5}^{\text {th }} \mathbf{1}^{\text {quintile }} \\
\text { Rank }\end{array}$ \\
\hline $\begin{array}{l}\text { Latin } \\
\text { Caribbean }\end{array}$ & 50.15 & & 37.92 & & 61.88 & & 6.05 & & 16.02 & \\
\hline Bolivia & 42.04 & 1 & 42.04 & 6 & 42.04 & 1 & & & 8.58 & 1 \\
\hline Jamaica & 42.90 & 2 & 37.92 & 1 & 54.31 & 11 & 4.81 & 11 & 8.75 & 2 \\
\hline Ecuador & 43.00 & 3 & 43.00 & 8 & 43.00 & 2 & & & 9.82 & 5 \\
\hline Venezuela & 44.42 & 4 & 39.42 & 2 & 53.84 & 10 & 4.27 & 10 & 10.93 & 7 \\
\hline Costa Rica & 46.00 & 5 & 42.00 & 5 & 50.00 & 5 & 2.97 & 5 & 13.13 & 10 \\
\hline Trinidad & 46.21 & 6 & 41.72 & 4 & 51.00 & 8 & 3.79 & 9 & 18.31 & 15 \\
\hline Dom. Rep. & 46.94 & 7 & 43.29 & 9 & 50.46 & 7 & 3.35 & 7 & 11.06 & 8 \\
\hline Barbados & 47.18 & 8 & 45.49 & 11 & 48.86 & 4 & 2.38 & 2 & 17.56 & 14 \\
\hline Peru & 47.99 & 9 & 42.76 & 7 & 55.00 & 13 & 5.42 & 14 & 9.21 & 4 \\
\hline Guyana & 48.19 & 10 & 40.22 & 2 & 56.16 & 14 & 11.27 & 16 & 9.15 & 3 \\
\hline El Salvador & 48.40 & 11 & 48.40 & 14 & 48.40 & 3 & & & 10.64 & 6 \\
\hline Nicaragua & 50.32 & 12 & 50.32 & 18 & 50.32 & 6 & & & 13.12 & 12 \\
\hline Puerto Rico & 51.11 & 13 & 50.15 & 17 & 52.32 & 9 & 1.11 & 1 & 22.20 & 17 \\
\hline Colombia & 51.51 & 14 & 46.00 & 12 & 54.50 & 12 & 2.68 & 3 & 13.94 & 11 \\
\hline Chile & 51.84 & 15 & 45.46 & 10 & 57.88 & 16 & 5.76 & 15 & 14.48 & 12 \\
\hline Panama & 52.43 & 16 & 47.47 & 13 & 57.00 & 15 & 5.01 & 12 & 22.64 & 18 \\
\hline Mexico & 53.85 & 17 & 50.00 & 16 & 57.90 & 17 & 3.09 & 6 & 17.12 & 13 \\
\hline Honduras & 54.49 & 18 & 50.00 & 16 & 61.88 & 20 & 3.63 & 8 & 27.74 & 20 \\
\hline Guatemala & 55.68 & 19 & 49.72 & 15 & 59.06 & 18 & 5.18 & 13 & 20.82 & 16 \\
\hline Brazil & 57.32 & 20 & 53.00 & 19 & 61.76 & 19 & 2.72 & 4 & 23.07 & 19 \\
\hline
\end{tabular}

Source: K. Deininger/L. Squire (1996), pp. 574 ff. 
In conclusion, it therefore remains to be emphasized that the inequality of income distribution in Latin America and its countries is considerable taking a worldwide comparison with other countries, and particularly with countries which have a roughly equally high per capita income although there are significant differences in the Gini coefficients within Latin America. ${ }^{1}$ Amongst the Latin American countries Brazil stands out with an extremely unequal distribution.

\subsection{Poverty}

Frequently, poverty is measured by the headcount index which is calculated as percentage of the poor in total population. Poor are those whose income falls short of a minimum expenditure - the poverty line - needed to cover the expenses for subsistence. For international comparisons very familiar poverty lines are one or two dollar(s) a day, measured at purchasing power parities of 1985 (\$PPP1985). ${ }^{2}$ Besides there are numerous national poverty lines used by national authorities or individual researchers. A common feature is that they increase with national aggregates (income or consumption) per capita (Ravallion/Datt/van de Walle, 1991). At given incomes and their distributions the higher the poverty line is the higher is the headcount index. Headcount indexes are now available for a multitude of countries however most of them calculated with different poverty lines which make it difficult to compare poverty indexes between countries (Tabatabai, 1996).

The headcount index is a rather crude measure of poverty which is completely insensitive to transfers between the poor provided their incomes do not pass the poverty line in the post transfer situation. To be more precise: The headcount index fails to fulfill axioms usually thought to be important for measures of poverty. ${ }^{3}$

This criticism is partly overcome with the help of group of poverty measures developed by Foster/Greer/Thorbecke (1984). These measures are given by the following poverty index $\left(\mathrm{PV}_{\alpha}\right)$

1 Table 1 leads one to conclude that there was practically no change in the Latin American income distribution since the seventies. This is partly a result of the method used by Deininger/Squire to calculate regional averages as unweighted means. Based on their estimation of annual Latin American Lorenz curves Londoño/Székely showed firstly that the level of inequality (represented by a Gini coefficient of 58 percent in 1970) was usually much higher and secondly that there was a more or less steady decline of the Gini coefficient by four percentage points from 1970 - the first year of their analysis - until the outbreak of the debt crisis in 1982. Since then the Gini coefficient went up again until 1984/85, falling in 1986 and gaining again the 1970 level in 1990. Since then it oscillated around that value.

2 The lower line of 1 dollar a day coincides with national poverty lines of poor countries (Ravallion/ Datt/van de Walle, 1991).

3 These are the axioms of monotonicity, of transfer, of transfer sensitivity and that of level sensitivity. 


$$
P V_{\alpha}=\frac{1}{n} \sum_{i=1}^{q}\left(\frac{z-y_{i}}{z}\right)^{\alpha}
$$

where $\mathrm{n}$ is the population, $\mathrm{q}$ the number of those whose income is below the poverty line $z, y_{i}(i=1 \ldots q)$ the income of the poor and $\alpha$ a parameter of poverty aversion. Setting $\alpha$ equal to zero equation (1) is equivalent to the headcount index. With $\alpha=1 \mathrm{PV}_{\alpha}$ results in the poverty gap which indicates the relative average income shortfall of the poor across the whole population while with $\alpha=2 \mathrm{PV}_{\alpha}$ results in a measure of poverty intensity which is sensitive to transfers between the poor.

The headcount index is determined by mean income, the level of the poverty line and the distribution of individual incomes around the latter. Thus, under cet. par. assumptions the lower is mean income or the worse is the distribution of income or the higher is the poverty line the higher is the headcount index. Therefore, in an international context, the same headcount index for different countries or groups of countries can be the result of widely diverging poverty lines, mean incomes and income distributions.

The following analysis uses two data sets, but both with serious disadvantages. The first is from Londoño/Székely (2000). This set only contains data for Latin America. Their advantage is the use of a common poverty line and the presentation of annual data on poverty. The other set is my own data set. It consists of a sample of 25 countries, 13 of them from Latin America. The rest besides Egypt and Tunisia is from Asia. The disadvantages of this set are a) the use of countryspecific poverty lines converted into dollars at purchasing powers of 1985 and b) the relatively small sample size (25 countries in the period from 1970 to 1990).

The headcount index is determined by mean income, the level of the poverty line and the distribution of individual incomes around the latter. Thus, under cet. par. assumptions the lower is mean income or the worse is the distribution of income or the higher is the poverty line the higher is the headcount index. Therefore, in an international context, the same headcount index for different countries or groups of countries can be the result of widely diverging poverty lines, mean incomes and income distributions.

The following analysis uses two data sets, but both with serious disadvantages. The first is from Londoño/Székely (2000). This set only contains data for Latin America. Their advantage is the use of a common poverty line and the presentation of annual data on poverty. The other set is my own data set. It consists of a sample of 25 countries, 13 of them from Latin America. The rest besides Egypt and Tunisia is from Asia. The disadvantages of this set are a) the use of countryspecific poverty lines converted into dollars at purchasing powers of 1985 and b) the relatively small sample size (25 countries in the period from 1970 to 1990). 
I begin with my own data set. In the light of the results from regional averages of the Gini coefficients one would expect higher poverty ratios for the group of Latin American countries when incomes and poverty lines elsewhere are at comparable levels. However, in this sample of countries real GDP per capita (in \$PPP1985) of the Latin American group of countries was 136 percent higher than that of the rest of the sample which are mostly Asian countries while the average Latin American poverty line was only 108 percent higher than that of the rest of the sample. However, comparing the regional averages of the headcount indexes one is impressed to observe that poverty rates in the rest of the sample (29.9 percent) are nearly the same as in Latin America (30.1 percent). ${ }^{1}$ Thus, according to the assured minimum income criterion Latin America does not seem to be more „unjust" than the countries in the rest of the sample which are mostly Asian.

This, however, is not the whole truth. As shown by Ravallion/Datt/van de Walle (1991) national poverty lines increase with respect to consumption or GDP per capita. In their sample the elasticity of the poverty line with respect to mean consumption was 0.66 . Using my own sample I calculated an elasticity of the poverty line with respect to per capita GDP of 0.83 . These results show that the poverty line increases with income or consumption. But it does so to a lesser extent. Therefore, in this situation one would expect a decline of the headcount index in countries with higher per capita incomes if the distribution of income is roughly similar in both groups of countries. As shown in section 2.1 this was not the case. Once again this result demonstrates that the inequality of the income distribution in Latin American countries is a serious matter of concern.

Although this is obvious from the data it is still not the whole truth. The averages hide developments through time. As already the scant data in the World Development Report of 1990 suggested Latin American countries experienced a declining headcount index during the years until the outbreak of the debt crisis in 1982 (World Bank, 1990). The same tendency was also observed for many Asian countries during this period, but while in many of the latter the decline continued many of the Latin American countries experienced - at least temporarily - an increase of their headcount indexes during the eighties.

For Latin American countries the same pattern is obtained from the data from the Londoño/Székely data set (Londoño/Székely 2000). ${ }^{2}$ Using a common poverty line of 1 (2) \$PPP1985 they measure extreme (moderate) poverty by the headcount, the poverty gap and the poverty intensity indexes as regional averages. ${ }^{3}$ Figure 2 shows these measures for moderate and extreme poverty

\footnotetext{
${ }^{1}$ The headcount index for the Asian countries alone is 30.2 percent.

2 They report nearly the same regional average headcount index (32\%) as I calculated from my data set for the period 1970-1990. However, they included regional poverty data until 1995.

3 According to the Foster/Greer/Thorbecke measures of poverty the calculate indexes using $\alpha=0,1$, and 2 .
} 
respectively. ${ }^{1}$ In the case of the headcount indexes for moderate and extreme poverty there is a steady decline for both indexes until the outbreak of the Latin American debt crisis in 1982. After a sudden surge there is again another local minimum of both headcount indexes in 1986. Since then these indexes increase substantially until 1990 . For both poverty lines 1990 marks the maximum. After that there is a slight decline which is far less pronounced than that occurring during the seventies and beginning eighties in spite of the fact that per capita incomes increased on a regional scale. In terms of poverty prevailing in 1970 moderate poverty nearly halved until 1982 while extreme poverty decreased only to 58 percent during the same period. Since then extreme poverty approached 91 percent and moderate poverty 81 percent of their respective levels in 1970. Measured by the headcount index this shows that in both periods it is more difficult to eradicate extreme poverty by income growth.

Figure 2: Measures of moderate $(M)$ and extreme $(X)$ poverty in Latin America

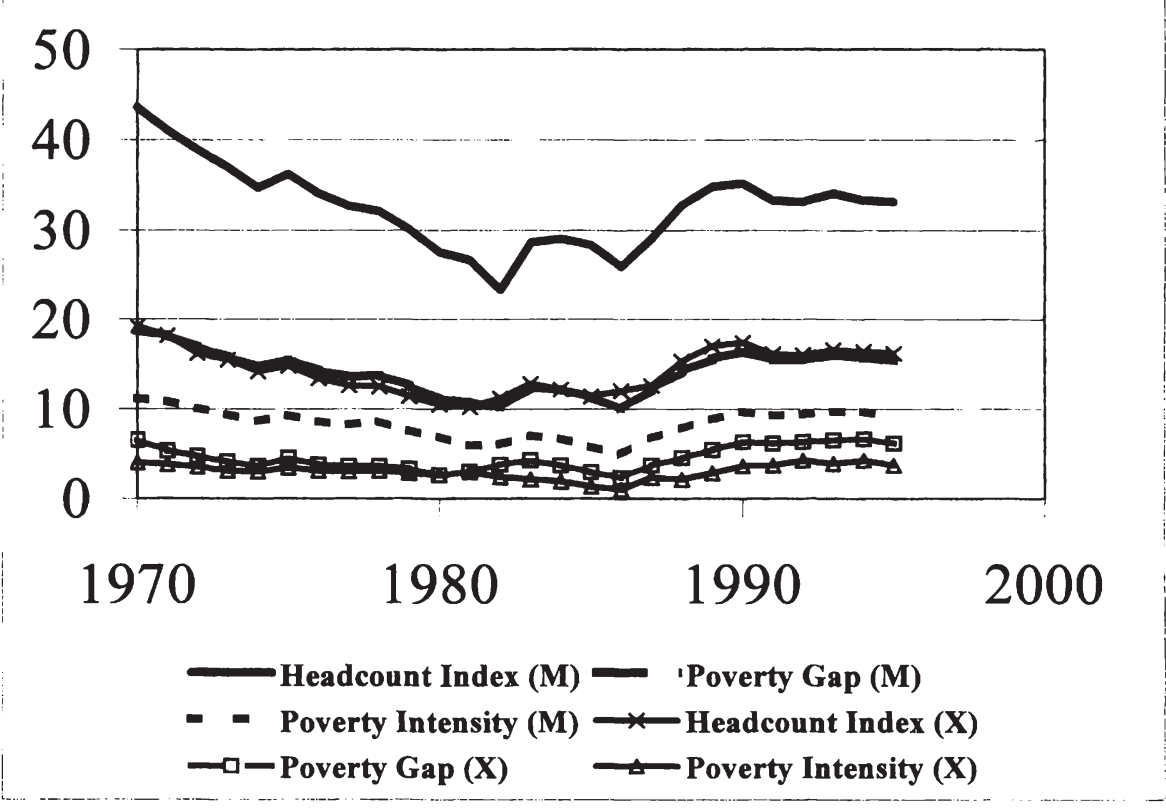

Data: Londoño/Székely (1997)

1 Moderate poverty is obtained from using a poverty line of 2 \$PPP1985 a day while for extreme poverty a line of 1 \$PPP1985 applies. 
With only minor changes the same pattern is obtained from the other two poverty measures. It is interesting to note that for both poverty lines the poverty gap and the intensity have their minimum in 1986, four years later than that of the headcount indexes. This shows that those who stayed poor became less severe poor on average until 1986 when the percentage of the poor was already increasing. New poverty created since 1982 involved individuals with incomes below but near to the poverty line. Only since 1986 poverty really worsened. In the case of moderate poverty while the headcount index increased by 36 percent from 1986 to 1990 , the poverty gap and the poverty intensity were raised by 64 and 98 percent respectively. Even more pronounced was the increase in extreme poverty. Between 1986 and 1990 the headcount index grew by 45 percent, but the poverty gap and the intensity of poverty increased by 174 and 260 percent respectively. In some years at the beginning of the nineties extreme poverty was even higher than twenty years ago. This increase in all poverty measures during the eighties was a phenomenon that was only attributable to Latin America (Chen et al., 1994).

In the appendix of their working paper Londoño/Székely (1997) report headcount indexes for 13 Latin American countries in the years 1970, 1980, 1989 and from the nineties. These data are reproduced in Table 3. In each column countries are ranked from highest to lowest headcount index. Although there are some remarkable changes in the poverty ranks for some countries, the rank of the majority of them is relatively stable. Always top on the poverty ranking is Honduras with an average headcount index of 68 percent, followed by Panama with 48 percent. On the other side of the ranking are Venezuela and the Bahamas with 16 and 7 percent respectively. Colombia, Mexico, and Guatemala experienced major changes in their ranks. Since 1970 Colombia succeeded in progressing to six higher ranks. This was the largest positive change over the whole period. Next to Colombia is Mexico which changed its ranks positively by five during the seventies when the oil bonanza contributed much to the income increase in that country. On the other side there is the remarkable deterioration of Guatemala's ranking. Since the seventies there was a decline by six ranks. In all cases these changes are paralleled by movements in the respective Gini coefficients.

Summarizing, the seventies witnessed a decline in poverty throughout Latin America, although not all countries participated in the same proportion. This process ended in the early eighties and definitely so in 1986. Since then social conditions worsened considerably reflecting the low growth episode of the lost decade. But even since the beginning of the nineties when growth set in again there was no clear tendency in the development of inequality and poverty for the subcontinent as a whole. A very striking feature of the Latin American situation is the strong impact of the distribution on the development of poverty. 
Table 3: Moderate poverty in 13 Latin American Countries

\begin{tabular}{|l|c|l|c|}
\hline & 1970 & & 1980 \\
\hline 1 Honduras & 70.3 & 1 Honduras & 65.5 \\
\hline 2 Colombia & 53.5 & 2 Panama & 40.6 \\
\hline 3 Panama & 52.7 & 3 Dominican R. & 37.3 \\
\hline 4 Dominican R. & 49.9 & 4 Costa Rica & 29.6 \\
\hline 5 Brazil & 49.4 & 5 Jamaica & 29.1 \\
\hline 6 Mexico & 40.5 & 6 Brazil & 28.2 \\
\hline 7 Jamaica & 36.3 & 7 Colombia & 27.9 \\
\hline 8 Peru & 29.9 & 8 Guatemala & 26.0 \\
\hline 9 Costa Rica & 26.0 & 9 Peru & 24.2 \\
\hline 10 Guatemala & 26.0 & 10 Chile & 23.5 \\
\hline 11 Venezuela & 24.0 & 11 Mexico & 18.8 \\
\hline 12 Chile & 20.6 & 12 Venezuela & 11.1 \\
\hline 13 Bahamas & 10.3 & 13 Bahamas & 3.3 \\
\hline
\end{tabular}

\begin{tabular}{|l|c|l|c|}
\hline & 1989 & & $1990 s$ \\
\hline 1 Honduras & 69.2 & 1 Honduras & 65.6 \\
\hline 2 Panama & 50.0 & 2 Panama & 48.4 \\
\hline 3 Brazil & 45.4 & 3 Brazil & 43.5 \\
\hline 4 Guatemala & 45.0 & 4 Guatemala & 42.5 \\
\hline 5 Peru & 37.6 & 5 Dominican R. & 39.5 \\
\hline 6 Dominican R. & 35.7 & 6 Peru & 35.0 \\
\hline 7 Chile & 31.3 & 7 Jamaica & 25.1 \\
\hline 8 Jamaica & 28.9 & 8 Colombia & 23.8 \\
\hline 9 Costa Rica & 25.3 & 9 Chile & 23.5 \\
\hline 10 Colombia & 23.5 & 10 Mexico & 22.3 \\
\hline 11 Mexico & 21.4 & 11 Costa Rica & 22.1 \\
\hline 12 Venezuela & 14.3 & 12 Venezuela & 13.4 \\
\hline 13 Bahamas & 6.8 & 13 Bahamas & 8.9 \\
\hline
\end{tabular}

Data: Londoño/Székely 1997 


\section{Causes of inequality}

Incomes ultimately originate from the ownership of assets, i.e. the ownership of labor, land and physical as well as individual human capital. Where human capital is extremely scarce, i.e. an untrained labor force is plentiful available in proportion to the stock of physical capital, a large part of the population receives relatively low incomes, and where there is a strong concentration of ownership of land and capital, a small part of the population earns relatively high incomes from land and capital assets. In the medium to longer term, income distribution therefore depends on the distribution of assets and human capital. By contrast, short-term fluctuations of the Gini coefficient may be the result of variations in the level of economic activity.

Income distribution in Latin America has therefore since long been explained in terms of concentration of land ownership. As shown by Deininger/Squire (1998) Latin America has had the highest land Gini coefficients in every decade with the exception of Eastern Europe where the tremendous increase of the land Gini over time reflects the doctrine of the former socialist regimes. Three versions of the land ownership argument can be found in the literature. According to the first, ownership of land directly influences income distribution by the incomes and rents received from land (Nelson et al. 1971, Cline 1975, Di Filipo 1977, Cardoso/Fishlow 1989).

Another line of argumentation takes the persistence of inequality into account and uses of arguments of political economy and capital market imperfections (Li/Squire/Zou 1998). In particular $\mathrm{Li}$ et al. argue that the rich have the power to influence policy to their own interest to protect their wealth. Further, land is a preferred asset to be used as collateral. As financial markets are imperfect, only those can obtain credit who own land or other assets that can be used as collateral in credit contracts. As the poor usually lack assets they are excluded from the credit market and from realizing productive, lumpy investments, especially in human capital. Thus the poor stay poor when the distribution of land is unequal. Li/Squire/Zou (1998) find ample evidence for this in their regression analysis.

In the third argument, a high land Gini is equivalent to a low level of human capital. This result is obtained when two different lines of arguments are combined. The first of them relates a high concentration of land to an intensive use of natural resources (Birdsall/Londoño, 1997). ${ }^{1}$ In a second line of argument Leamer et al. (1999) maintain that low levels of human capital result from the intensity of resource use. Thus, they explain the low level of human capital which one usually assumes to exist in Latin America, by its endowment with natural resources. Combining both arguments, one may conclude that a low level of human capital results from a high land concentration.

1 Unfortunately, Birdsall/Londoño do not explain the channel of this relation. 
All these explanations are not totally convincing. With respect to the first argument, nowadays the concentration of land ownership in Latin America no longer has the explanatory power which it had earlier been credited with. On the one hand, it should be pointed out that in the industrialization process the relative significance of industrial assets has risen and thus that of land ownership has fallen. At the same time the agricultural share in the gross domestic product has decreased considerably in the past 30 years. In 14 Latin American countries the unweighted average of the share of the agricultural sector in the gross domestic product fell from $22.6 \%$ in 1965 to $13.4 \%$ in 1993 , and in the largest countries (Argentina, Brazil, Colombia, Mexico, Peru and Venezuela) from 17\% to below $10 \%$ (World Bank 1995). If the concentration of land had had such a great direct influence on income distribution over the whole period, this development would necessarily have found expression in the level of the Gini coefficient. Instead of this the income Gini coefficient of the individual countries in Latin America has scarcely changed over the course of time, if the short-term fluctuations are disregarded (Deininger/Squire, 1998).

The second argumentation implies that there is considerable persistence in the constancy of the Gini coefficient at least in Latin America. Two contradictory results are to be found in the empirical literature. The first of them are the findings from Li/Squire/Zou (1998). They found that differences in the Gini coefficients are mostly between countries, not within them. ${ }^{1}$ The second is from the analysis of Londoño/Székely (1997) who show that based on the hypothetical income distribution for Latin America the overall Gini coefficient changed to a considerable extent over time (see note 4 in section 2.1 above). From the latter one may conclude that the assumption of constant Gini coefficients is not well established.

The third argument is based on the assumption that the level of human capital is low in Latin America compared with other regions (Londoño, 1996). Briefly, the hypothesis of inadequate formation of human capital runs as follows: Compared with countries at a comparable level of development, the formation of human capital in Latin America is insufficient. This view expressed by Londoño (1996) seems to be supported by his findings of the cross sectional analysis in which per capita income and its square were regressed on an educational index from the Human Development Report of 1994. On the basis of these regression

1 In 32 out of 49 countries in their sample the Gini coefficient does not follow a time trend. In the remaining 17 cases 7 countries show a negative and 10 countries a positive trend. Further, they demonstrate in an analysis of variance that in their whole sample $92 \%$ of total variance is explained by country effects. The time effect is insignificant. In their sample only 5 out of 12 Latin American countries (Bahamas, Chile, Honduras, Jamaica and Venezuela) had a significant time trend, two of them with a positive sign (Chile and Venezuela). At the regional level the weight of each of the latter two groups with significant time trends is low, however. 
results he demonstrates that for Latin America's per capita income a higher education index than that actually realized would have to be achieved.

A critical objection to Londoño's regression result is that education is determined by the per capita income. If a country's educational index is below the standard according to its per capita income, the country has formed too little human capital. In order to justify this proposition the causality must run from income to education. This contradicts the conclusions of the more recent growth theory, that shows that human capital is for its part an important variable for explaining economic growth (Barro 1991; Mankiw/Romer/Weil 1992; Barro/Sala-i-Martin 1995). From this perspective, the causality which Londoño takes as a base is completely reversed. It would therefore make more sense to assume that both variables (income and education) are simultaneously determined by other exogenous variables. So it must be presumed that Londoño's result is biased and that his proposition of an inadequate formation of human capital in Latin America lacks empirical evidence.

Another demonstration of the lack of human capital in Latin America is more indirect. As pointed out in the 1998-1999 report of the Inter-American Development Bank (1998) the population in Latin America aged 25 to 65 years has 4.8 years of schooling on average while that in industrial countries has about 8.4 years. The principal objection against this argument is that mean years of schooling are input indicators and nothing can be said about the productivity of human capital formation in both types of countries. The same would be true when comparing Latin American with Asian countries. Thus, this third argument rests on preconditions that are not well founded empirically.

Finally, the equivalence of high levels of land concentration and low levels of human capital is questionable for two reasons at least. First, the data do not seem to support this thesis. In the Deininger/Squire (1998) calculation of decade means of the Gini coefficient for the land distribution the Sub-Saharan African countries show nearly the same low land concentration as East Asia and the Pacific. It is hard to believe that both regions should have the same level of human capital. Second, in a regression analysis that includes both the land Gini and a human capital variable one would expect that one of them looses significance when the other is included in the equation. Using the results from Birdsall/Londoño (1997) in which both variables entered the same regression as values for the initial years both variables are significant at the $5 \%$ level. Thus, none of the three human capital arguments seems to be well founded on empirical grounds.

Therefore, one must look for other explanations of the apparently high income concentration in Latin America. In this respect, reference must be made to two not mutually exclusive explanations: a) the cost of economic reforms and adjustment measures which primarily adversely effect low income earners (Bulmer/Thomas 1996; Sautter/Schinke 1994) and b) the multi-argument 
reasoning in the BID-Report of 1998-99 (Inter-American Development Bank 1999).

The first argument only refers to the post-reform years in Latin America. Therefore, it can only be used as an explanation of the high Gini coefficients in the late eighties and in the nineties. Adjustment measures and economic reforms which became necessary to overcome the stagnation of the $1980 \mathrm{~s}$, involve considerable social costs (Sautter/Schinke 1994) which often affect the lower population quintiles more than the upper ones (Bulmer-Thomas 1996). This is at least true in the short run; whether over the longer term the reform-induced trend rates of economic growth will increase, thereby over-compensating for the resulting losses in income, is still a widely open question, although a study by Kakwani (1996) shows that in a sample of countries reform-induced positive growth effects were apparent. In any event, economic reforms and adjustment measures influence key variables of the economy such as real wages, employment, inflation rates and interest rates (Bulmer-Thomas 1996). The distribution effects of these measures are not neutral, but primarily adversely affect low (labor) income earners. Thus, for example, the liberalization of foreign trade as well as fiscal and labor market reforms regularly lead to a reduction of the real wage rate. A real devaluation which is usually a part of the trade liberalization policy package raises the prices of tradable goods compared with those of nontradables. In the case of very open economies, a devaluation will lead to an increase in the price level and thus, other things being equal, to a fall in real wages. If, in addition, non-tradable goods are used as inputs in the production of import substitutes, despite the devaluation-induced price advantage, their competitiveness will be considerably reduced by this rise of the price level and by the reduction of Tariff protection. This will result in unemployment, since experience shows that business closures occur more rapidly than the building-up of new production plants in the export sector. Likewise, the compulsion to reform the national budget and reduce the budget deficit will lead to a fall in employment in the public sector and to a pressure on real wages. The lower quintiles will mainly be affected by all these measures, although they will benefit from the lowering of the inflation rate through the associated reduction of the inflation tax. However, this is subject to the individuals being on the „right” side of the inflation tax Laffer curve (Agenor/Montiel 1996). As a rule, the reform of the domestic capital market involves a rise in real interest rates and share quotations. Both primarily benefit higher income earners. The relevance of these considerations would have to be tested in each specific individual case. Nevertheless, a glance at the statistics shows that in many countries which have introduced adjustment programs the Gini coefficient rose toward the end of the eighties and sometimes in the early nineties as well.

The principal idea behind the explanation of Latin American inequality given in the BID-Report 1998-99 is the abandonment of a mono-causal explanation of the income distribution (Inter-American Development Bank, 1998). In that 
report the authors detect two different types of causes that have lead to the unequal distribution of income in Latin America. The first of them is related to the stage of development, the other is of structural origin. With respect to the stages approach the authors of the report have identified five development trends that tend to foster inequality during early stages of economic development while leading to more equality later on: the accumulation of capital, urbanization and formalization of the economy, education and the demographic process.

In the early process of capital accumulation, capital is scarce and its marginal product high. With still high returns on capital the share of capital income in total income will rise with the accumulation of capital. At later stages profit shares tend to decline. The report identifies the Latin American situation as one where returns to capital are still high but where in the not too distant future the share of capital income will decline.

With respect to urbanization the argumentation in the report follows the lines usually put forward in the explanation of the Kuznets curve. The economy exists of two sectors: a low income-low inequality rural sector and an urban sector with higher income levels and higher inequality. At the beginning of its development process migration to the cities involves a process of increasing inequality. During this stage the income distribution is mainly characterized by the distribution of rural incomes. When more and more workers migrate the rural-urban wage gap increases and the distribution of income will be determined more and more by the relatively unequal distribution in the urban sector and the inequality between both sectors. Later on when most workers have migrated to the urban sector the rural-urban wage gap looses significance for the whole distribution which is then mainly determined by the inequality existing within the urban sector. For Latin America this process is already advanced. As most Latin Americans live in cities today it can be expected that inequality stops rising as migration looses importance. In the same manner the formal-informal sector wage gap increases first and looses importance later in the development process with the decline of the informal sector where wages for jobs with similar characteristics differ much more than in the formal sector.

At low levels of development the educational level is low, too, and the resulting inequality as well. Expansion of the educational system over time leads to better educated cohorts. Within these cohorts inequality may still be strong. But as time goes by expansion of the educational system to less privileged areas leads to a reduction of intra-cohort inequality. According to the BID-Report, in Latin America inequality between cohorts is still high while intra-cohort inequality is already declining.

During the process of demographic transition in which fertility declines follow the decline in mortality with a time-lag, the early phases are characterized by a low age of the population and high numbers of children that need to be fed thus reducing per capita income as the number of wage earners in the families is low. 
In that stage educational attainment is low and distributed unevenly as society lacks the resources for quick improvements in the educational system thus leading to a high degree of inequality. In Latin America fertility rates are declining and the participation rate of women increases. This leads to a smaller family size with less children who will be better educated. Again this will lead to lower inequality in the future. According to the BID-Report these five trends explain one third of the difference in income inequality between industrialized countries and Latin America.

Another group of factors that leads to inequality is structural: (1) the endowment with natural resources and above all with land and its unequal distribution and (2) the exposure to external shocks. In contrast to the land distribution arguments above this time the argument is more refined: It applies most to the tropical plantations with economies to scale. There, adverse climatic conditions and less technological innovations lead to depressed wages of unskilled labor. This type of economy has also „... promoted vertical relationships, hierarchies and class divisions rather than the horizontal linkages that build social capital and contribute to development and equity" (p.4).

Further, the Report mentions the capital intensive nature of the exploitation of the region's resources together with its low capacity to absorb labor thereby raising the price of capital utilization and reducing the availability of capital in the manufacturing sector and increasing the abundance of labor. This reinforces the pressure on wages and leads to inequality.

External shocks tend to increase the Gini coefficient and to reduce growth.. Those who cannot afford the means to protect themselves against volatility may therefore be hit twice if one accepts a Kuznets-type of association between income and inequality. An important channel by which a volatile environment exerts its influence on distribution is that the formation of human capital maybe seriously damaged in periods of economic crisis. In developing countries the drop-out rate dramatically increases when economic activity slows down. This is in contrast to the experience made in developing countries. Even more important is the fact that those who left school nearly never go back to school when incomes are rising again.

Although the authors find ample support for their hypotheses in their regressions it is sometimes difficult to interpret some of the results. This is mainly due to their eclectic approach. Their basic equation which is the starting point for all other regressions is of the Kuznets type where the Gini coefficient is explained by GDP per capita, its square and a dummy variable for Latin American countries. Both income coefficients have the expected signs and are highly significant. The dummy variable shows that the Gini coefficient is ten percentage points higher in Latin America than elsewhere. In Latin America maximum inequality is achieved with a per capita income of 1100 \$PPP1985 and a Gini coefficient of about 53 percent. In most of the other regressions 
((2) - (7)) this Kuznets type relationship is abandoned. Instead the authors of the BID Report rely on environmental factors and some developmental variables that are correlated with income per capita. There remains a suspicion that the Kuznets relationship ceases to be robust after the inclusion of other explanatory variables. A similar result has been obtained by Deininger/Squire (1998). Further, it is not clear what their results would be had they included country specific effects. Using nearly the same data set as that used by the IDB researchers, Deininger/Squire (1998) get results that lead them to reject the Kuznets relationship. In all, the IDB approach is a promising one, but it is only a first step to be pursued with more scrutiny in the future.

\section{Consequences of inequality}

\subsection{Distribution and development}

The consequences of unequal income distribution in Latin America and elsewhere could be eased if a systematic connection between economic development and an improvement of income distribution could be established. In this respect it should be borne in mind that more or less every government adopts measures in some form or another to improve income distribution. The connection between distribution and development is thus always the product of these measures, which have often been taken after public pressure because the prevailing inequality was untenable. In a narrower sense it is therefore difficult, if not completely impossible, to discern from international or national statistics a systematic connection between the development of income distribution and per capita incomes (Hesse/Sautter, 1977). However, the political pressure to adopt measures to improve income distribution, based on political and economic considerations, can also be regarded as a systematic connection between distribution and development, on which the following comments will focus.

In 1955 Kuznets published the hypothesis that in the development process income distribution initially worsened and in the later stages of economic development improved again (the 'hypothesis of the inverse $U$ ', or more briefly the 'U hypothesis'). Although his expositions are based on insufficient statistical material, they have considerably stimulated the discussion. The examination of this hypothesis is still continuing. If, when the discussion began, it was primarily considerations of sectoral differences in the level and distribution of income which formed the basis of the hypothesis, it is now capital market imperfections which lead to differences in the formation of human capital (Banerjee/Newman, 1993; Aghion/Bolton 1994; Perotti, 1993) amongst higher and lower income earners and thus to variations in wage rates in the development process, or the varying supply of human capital in the early stage of economic development which is necessary to initiate the growth process (Galor/Tsiddon, 1996). The studies published until recently seemed to approach a conclusion: In cross- 
sectional analyses the results were mixed. Some seemed to confirm the $\mathrm{U}$ hypothesis (Ahluwalia, 1976; Lindert/Williamson, 1985; Adelman/Robinson, 1989), and others to refute it (Anand/Kanbur, 1993; Fields, 1989; Fields/Jacubson, 1993). On the other hand, longitudinal studies of industrialized countries were largely in conformity with the $\mathrm{U}$ hypothesis (cf. in this connection the literature cited in Galor/Tsiddon (1996)). Finally, the report of the Inter-American Development Bank (1998) seems to lend support to the Kuznets hypothesis in its first two regressions. Since from the available findings it can in no way be deduced with certainty that in the development process mechanisms develop which lead to more income equality it is important to discuss the consequences of inequality in greater detail. Because of its particular significance for poverty, the effect of an unequal distribution on growth should be discussed.

\subsection{Effects of inequality on economic growth}

In the discussion of to what extent development influences income distribution, the causality ran from the level of development to distribution. In the question now to be investigated, the causality is reversed: It will be investigated to what extent inequality can influence economic growth. This question has been the subject of several studies in recent years (Alesina/Rodrik, 1993; 1994; Persson/Tabellini, 1994). The core hypothesis of these studies is that in societies with considerable inequality the demand for redistribution through taxation of capital is great. This leads to distortions in the economy and is reflected in a low growth rate. The cited studies contain empirical evidence for the hypothesis put forward. In a further study Alesina/Perotti (1996) investigated the question of whether political instability, measured as an index based on indicators of social unrest and political violence, can explain the connection between inequality and lack of investment activity. Specifically, their hypothesis is that income inequality fosters socio-political instability, which in turn negatively influences the willingness to invest. An impoverished class which is confronted with a small group of prosperous people will demand radical changes in the distribution of income. Capital flight, production stoppages and the violation of property rights will be the consequence. The analysis of this connection is important because in earlier studies on the relationship between income inequality and economic development it had been assumed that inequality had been conducive to economic growth. Since the rich save more than the poor, the more unequal distribution is the higher the savings in the overall economy. From this perspective, every economic policy initiative aimed at an improved distribution of income will go awry, since savings in the overall economy will fall. The consequence is lower investments than would otherwise be possible and thus a lower rate of economic growth. In an empirical study both effects can overlap. It is therefore important to introduce an additional link - in this case ,political instability" - and isolate its effect in the overall relationship. 
According to the empirical conclusion arrived at by Alesina/Perotti, the hypothesis of the connection between inequality and investment activity via political instability cannot be rejected. Their index of political instability is negatively correlated with investment activity and the income of the middle class - defined as the third and fourth quintiles - which for its part has a negative correlation with the income of the upper class (fifth quintile). From the significance of the dummy variables for Latin America in their regression analysis it is evident that this connection is particularly applicable to the countries of Latin America.

This conclusion is of great significance for economic and social policy: Should the state pursue an active redistribution policy which has to be financed through higher taxes, which is ultimately detrimental to investment activity, or is it better to accept these disadvantages in order to provide a positive incentive for investment activity via the increased political stability? Alesina and Perotti have shown that, despite its inherent costs, a redistribution policy can improve economic growth.

In the context of the present analysis the conclusion from this section is even more important for another reason: Income distribution and economic growth are of extraordinarily great importance for the explanation and alleviation of poverty. They determine the extent of poverty in a country. However, if over the longer term growth is dependent on distribution, income distribution will become the predominant determinant of poverty. On the other hand: if it is correct to assume the existence of a Kuznets-type association between income and distribution it is income that is ultimately the main determinant of poverty. This is still an unsolved question as the results from the research work that establishes the "distribution causes growth" nexus seems to rely on data of a doubtful quality (Deininger/Squire, 1996). Therefore, it is necessary to investigate the poverty - per capita income relation in more detail. Unfortunately, up to this moment the data do not permit a test which of the relations (Kuznets vs. political economy types) between income or growth and distribution is of greater relevance. But what can be done with my own data set is to investigate the influence that income and its determinants have on poverty without using distributional data as they are of doubtful quality. If it can be demonstrated that per capita income and/or its determinants have a significant influence on poverty this may be seen as a weak test in favor of the existence of a Kuznetstype relation between income and distribution.

\subsection{Determinants of poverty}

Poverty measured by the headcount index is mainly determined by the poverty line, the distribution of income (for which the Gini coefficient is only an approximation), and per capita income. Thus, under cet. par. assumptions we can assume that poverty is high when the distribution of income is unequal. In their analysis Londoño/Székely (1997) calculated an elasticity of the headcount 
index with the respect to the Gini coefficient of 1.9. ${ }^{1}$ Therefore, many of the causes underlying an unequal distribution of income are responsible for poverty as well: the lack of human and physical capital, bad health and working conditions, high fertility rates etc..

However, if one accepts the reasoning of the Inter-American Development Bank (1998) that income causes distribution and the argument that reforms have had an adverse effect in the short run then other determinants must be taken into account as well. In that case variables that capture the effect of income distribution on poverty are not really exogenous. At first sight the relation between poverty and growth seems to be simple. Higher incomes lead to lower poverty if the income distribution remains unchanged or if the poverty augmenting effect of a more unequal distribution is more than neutralized by the positive effect of higher incomes. Since the late eighties the poverty-reducing effect of income growth episodes has been identified (Fields, 1989). There is empirical evidence that poverty is negatively associated with higher incomes (Ravallion 1995; Sautter/Schinke 1995). The elasticity of poverty with respect to income or consumption is usually found to be negative and relatively high in absolute terms. Using a poverty line of 1\$ PPP1985 per day and per capita Ravallion (1995) calculated an elasticity of the headcount index with respect to consumption of -2.4 . Similar results were obtained in a study by Sautter/Schinke (1995) where the mean of the poverty elasticity with respect to income for seven countries was -2 , ranging from -0.45 for India to -3.5 for Bangladesh. In a case study for Costa Rica the respective elasticity was between -2 and -2.7 depending on the specification of the estimated equation (Schinke, 1997).

Taking the inverse relationship between poverty and income as given, one can estimate the effects, that the determinants of income exert on poverty. Using a neoclassical production function with both physical and human capital and labor as arguments in the simplest case the equation to be estimated is given by ${ }^{2}$

$$
\mathrm{HCI}=\mathrm{c}_{0}+\mathrm{c}_{1} \mathrm{NV}+\mathrm{c}_{2} \mathrm{SEC}+\mathrm{c}_{3} \mathrm{GEMPL}+\mu
$$

1 An even higher elasticity has been identified by Schinke (1997) in a time series analysis of the determinants of poverty in Costa Rica. Here, the Gini elasticity was between 2 and $4.6 \%$.

2 An equation similar to (2) is obtained by Mankiw/Romer/Weil (1992) using a CobbDouglas production function $\quad \mathrm{Y}_{\mathrm{t}}=\mathrm{K}_{\mathrm{t}}^{\alpha} \mathrm{H}_{\mathrm{t}}{ }^{\beta}\left(\mathrm{A}_{\mathrm{t}} \mathrm{L}_{\mathrm{t}}\right)^{1-\alpha-\beta} \quad$ where $\mathrm{K}$ is physical capital, $H$ human capital, $A$ the level of technology, $L$ labor, $\alpha, \beta$ fixed coefficients and $Y_{t}$ is output in period t. $\mathrm{L}$ and $\mathrm{A}$ grow at exogenously given rates $\mathrm{n}$ and $\mathrm{g}$. Further, it is assumed that saving rates $\mathrm{s}_{\mathrm{i}}$ and deprecation rates $\delta_{\mathrm{i}}$ are constant and the same for both types of capital $\mathrm{k}$ and $\mathrm{h}$ expressed in effective units of labor. Mankiw et al. showed that the log of per capita income is given by

$$
\ln \left(\frac{Y_{t}}{L_{t}}\right)=\ln A_{0}+g t+\frac{\alpha}{1-\alpha} \ln s_{k}-\frac{\alpha}{1-\alpha} \ln (n+g+\delta)+\frac{\beta}{1-\alpha} \ln h
$$


where $\mathrm{HCI}$ is the headcount index, INV the investment ratio, SEC human capital, GEMPL the growth rate of population in the age of 14 to 65 years and $\mu$ the respective error term with the usual properties. The expectation is that the signs of $c_{1}$ and $c_{2}$ are negative and that of $c_{3}$ positive.

This equation was estimated with a common intercept using the data of the sample described above. The results are in column (1) of Table 4. Rural and urban dummies were used respectively when the headcount indexes were available for these sectors only. Further, the poverty line (Z) expressed in \$PPP1985 per year and per person was included as independent variable. It is assumed that $\mathrm{Z}$ is exogenously determined by politicians or researchers. Usually the urban and rural dummies are highly significant and they indicate that rural poverty is higher and urban poverty lower than the national level. The coefficient of $Z$ is always positive and highly significant. With respect to the growth determinants (INV, SEC, and GEMPL) the table shows that they have the expected sign and are usually significant in all estimates (columns (1) to (8)).

Inclusion of per capita income (RGDPL) in the estimated equation should result in insignificant coefficients for INV, SEC, and GEMPL when these variables affect poverty only through their effect on income. If on the other hand they as well as income per capita show significant coefficients one can infer that they have effects that are not accounted for so far. In this sense it seems plausible to suggest that the investment ratio INV does not only reduce poverty by its positive effect on mean income but by increasing especially the incomes of the lower deciles. Higher investment may reduce poverty when the poor gain via positive external effects of investments in infrastructure. On the other hand they can raise the headcount index when investments mainly result in an increase of income of the upper segments of the income distribution. In the latter case one should expect a positive sign of the investment ratio in the poverty equation when per capita income is included. By the same token one should expect a negative sign of the human capital variable (SEC) when per capita income (RGDPL) is included, as an increase in human capital not only raises income but also allows a better use of available information on health and sanitation. With respect to the growth rate of the population (GEMPL) one may expect that it increases poverty apart from its effect on the reduction of the steady state capital stock. Persistently high rates of population growth lead to relatively high shares of children in the total population. These children must be fed, educated etc. For this group of the population it may be assumed that their marginal productivity is less than their real per capita consumption. Accordingly a positive sign can be expected in the income-per-capita-augmented poverty function. Column (2) shows that the inclusion of per capita income alters the values of the estimated coefficients only marginally leaving their significance levels unchanged. Further, the hypotheses that the coefficients of LINV, LSEC, and LGEMPL are jointly zero can be rejected at the $1 \%$ level. This can be regarded as proof that these variables exert positive (in the case of the investment and human capital variables) and negative (in the case of the population growth rate) effects besides those on per capita income. 
Table 4: Determinants of Poverty (HCI) (Panel Analysis with Common Intercept) ${ }^{1)}$

\begin{tabular}{|c|c|c|c|c|c|c|c|c|c|}
\hline independent variables & (1) & (2) & (3) & (4) & (5) & (6) & (7) & (8) & (9) \\
\hline Rural & $12.96 * * *$ & $8.14 * * *$ & $7.73 * * *$ & $8.82 * * *$ & $8.51 * * *$ & $8.10 * * *$ & $7.14 * * *$ & $8.60 * * *$ & $5.86 * * *$ \\
\hline Urban & 0.69 & $-5.27 * * *$ & $-5.69 * * *$ & $-3.74 * * *$ & $-4.33^{* * *}$ & $-4.74 * * *$ & $-6.16^{* * * *}$ & $-400 * *$ & $-3.98 * *$ \\
\hline $\mathrm{Z}$ & $0.006^{* * *}$ & $0.02^{* * *}$ & $0.02^{* * *}$ & $0.016^{* * *}$ & $0.017^{* * *}$ & $0.017^{* * *}$ & $0.019 * * *$ & $0.015^{* * *}$ & $0.017^{* * *}$ \\
\hline $\log$ INV & $-15.96^{* * *}$ & $-13.39 * * *$ & $-13.35^{* * *}$ & $-9.64 * * *$ & $-10.35^{* * *}$ & $-9.27 * * *$ & $-9.66^{* * *}$ & $-7.69 * * *$ & $-7.91 * * *$ \\
\hline $\log$ SEC & $-6.69 * * *$ & $-6.40 * * *$ & $-6.01 * * *$ & -1.37 & -1.89 & $-2.95 * *$ & $-8.28 * * *$ & $-4.16 * *$ & $-4.02 * *$ \\
\hline $\log$ GEMPL & $6.66 * * *$ & $4.36^{* * *}$ & $4.71^{* * *}$ & $6.46 * * *$ & $5.55 * * *$ & $4.58 * * *$ & $3.45^{* *}$ & $4.86 * * *$ & $4.34^{* *}$ \\
\hline $\log$ OPEN & & & $-1.91 * *$ & $-6.16^{* * *}$ & $-4.74 * * *$ & $-5.12 * * *$ & $-1.64^{*}$ & & \\
\hline Dlog OPEN & & & & & & 2.13 & 0.64 & & \\
\hline Dtlog OPEN & & & & & & & $-0.84^{*}$ & & \\
\hline DtDlog OPEN & & & & & & & $1.51^{* *}$ & & \\
\hline $\log$ Tariff1 & & & & $-3.35 * *$ & & & & 0.72 & \\
\hline Dlog Tariff 1 & & & & & & & & $-1.52^{*}$ & \\
\hline Dtlog Tariff1 & & & & & & & & 0.90 & \\
\hline DtDlog Tariff1 & & & & & & & & $-2.90^{* *}$ & \\
\hline $\log$ Tariff2 & & & & & $-3.01^{* * *}$ & $-4.07 * * *$ & & & -1.35 \\
\hline Dlog Tariff2 & & & & & & 2.09 & & & $-1.47^{*}$ \\
\hline Dtlog Tariff2 & & & & & & & & & 0.80 \\
\hline DtDlog Tariff2 & & & & & & & & & $-1.98^{*}$ \\
\hline $\log$ GOV & & & & & & $4.08^{*}$ & $9.84 * * *$ & 2.98 & $4.42^{*}$ \\
\hline $\log$ RGDPL & & $-13.26 * * *$ & $-12.13^{* * *}$ & -13.23 & $-14.34 * * *$ & $-15.01 * * *$ & $-11.78 * * *$ & $-15.77 * * *$ & $-17.52^{* * *}$ \\
\hline $\mathrm{R}^{2}$ (adj.) & 0.40 & 0.50 & 0.50 & 0.50 & 0.51 & 0.52 & 0.53 & 0.50 & 0.51 \\
\hline S.E. & 13.88 & 12.65 & 12.62 & 12.15 & 12.10 & 12.02 & 12.31 & 12.24 & 12.17 \\
\hline $\mathbf{F}$ & 71.77 & 92.6 & 82.1 & 55.02 & 58.1 & 44.9 & 60.40 & 40.38 & 41.80 \\
\hline obs & 323 & 323 & 323 & 259 & 259 & 259 & 323 & 259 & 259 \\
\hline
\end{tabular}

1) Levels of significance: * 10 percent, ** 5 percent, *** 1 percent 
Table 4 further reveals certain aspects of the reform arguments. A very important aspect of the economic reforms in Latin America that took place in the late eighties and beginning nineties was the liberalization of their foreign trade: the countries became more open. As explained above a well-known property of the reform process is that it exerts social costs which primarily affect the lower income strata. This may lead to an increase in poverty. On the other hand it is known from recent research (Edwards, 1998) that openness has positive effects on economic growth. Taking into account the inverse relationship between poverty and income one should expect a reduction of poverty when countries liberalize their foreign trade.

To test these hypotheses three variables of openness were used: the percentage of imports and exports in GDP (OPEN), the percentage of import duties in the value of imports (TARIFF1) and the percentage of government revenue from total trade in GDP (TARIFF2).

As column (3) shows openness defined as the relative volume of foreign trade reduces poverty. The estimated coefficient is significant at the 5 percent level ${ }^{1}$. But openness may have different facets. Besides the volume effect of the OPEN variable there may be structural or micro-economic effects that may be better captured by the tariff variables (TARIFF1 and TARIFF2). Inclusion of TARIFF1 shows that OPEN has a significant poverty reducing effect (column (4)). The same result is obtained when TARIFF2 is substituted for TARIFF1 (column (5)).

An important result, however, is that lower tariffs increase poverty. Thus, openness has at least two different facets with respect to its effect on poverty. Higher openness in the sense of a larger share of trade in GDP reduces poverty while the abolition of trade restrictions leads to more poverty.

It is often stated that Latin America differs from the rest of the world in several respects. Therefore, a regional dummy with Latin American countries equal to 1 and zero else was introduced. Multiplying this dummy by the respective openness variables results in the new variables in Dlog OPEN and Dlog TARIFF2 (column (6)). Both variables are insignificant at conventional levels. Thus, Latin America is not different from the rest of the countries in the sample over the whole period. ${ }^{2}$

In columns (7), (8) and (9) I tested for effects of openness with respect to country groups, to time periods and to both. A time dummy Dt was used being

1 Test of the hypothesis that the coefficients of the logs of INV, SEC, GEMPL, and OPEN are jointly zero can be rejected at the 1 percent level.

2 In the same regression we tested the influence of macro-economic effects by introducing the share of government consumption in GDP (GOV). Insignificance of this or the OPEN variable would indicate that OPEN is heavily influenced by macro-economic factors. As the results in column (6) show this does not seem to be important. Besides, it demonstrates the adverse effect of public consumption on poverty. 
one in the period since 1987 and zero else. ${ }^{1}$ Multiplying this dummy by the openness variables results in DtlogOPEN, Dtlog TARIFF1 and Dtlog TARIFF2. These variables should account for the effect of liberalization effects in the whole sample. Multiplying the regional dummies by the period dummies results in DtDlog OPEN, DtDlog TARIFF1 and DtDlog TARIFF2. They take on the values of the respective openness variables for Latin American countries since 1987 and are zero else and should indicate whether Latin America differed from the rest of the sample during the period of reforms. The results in these columns show:

- Overall openness as a fraction of trade in GDP reduces poverty.

- Latin America does not differ from the rest of the sample during the whole sample period: As in column (6) the dummy variable DlogOpen is insignificant.

- Liberalization of trade per se reduces poverty (the coefficient of DtLogOpen is negative and significant at the 10 percent level) but

- in Latin America openness increases poverty during the liberalization period. Both, a reduction of trade barriers and higher trade shares lead to higher headcount indexes in that period.

\section{Summary}

The present study has demonstrated that the indicators of social justice used in this research work exhibit certain peculiarities with regard to Latin American countries. Inequality and poverty should be regarded as a matter of concern for politicians and economists alike. Specifically, it has been shown that over the period from the 1950s to the present day income distribution in Latin America has been extraordinarily unequal although there have been changes since 1970 . Inequality applies both to the whole subcontinent compared with other world regions, as well as to the individual countries, if they are compared with countries at a similar level of development. Even within Latin America there are considerable differences in the degree of inequality.

Different approaches which can explain the extent and/or the permanence of inequality have been discussed:

1. The land ownership structure is often regarded as the classical explanation of inequality. However, since in past decades the proportion of income from land ownership in the total income of the economy has fallen considerably, this should be reflected in a reduction of the Gini coefficient. This is, however, scarcely discernible, if the development of this coefficient is compared with those of other regions.

1987 marks the beginning of the period of intense reforms in Latin America. 
2. The second argument referred to the persistence of inequality. Land is important for income distribution in as much as it can be used as collateral in credit contracts thus allowing to realize large indivisible investments especially in human capital. Combining this argument with those from the political economy school of thought an unequal land distribution can lead to a poverty trap where the poor stay poor. It has been argued in this paper that on closer inspection the Gini coefficient changed a lot during the period under analysis.

3. Concentration of land ownership may serve as a further explanation for a high inequality of income. This time a high concentration of land is correlated with the intensity of resource use, which leads to an inadequate formation of human capital in Latin America. Although the evidence produced thus far to support this hypothesis must be regarded as insufficient, some significance can be attached to this explanatory approach. Further studies are required here.

4. Changes in the distribution during the period after the outbreak of the debt crisis may also be attributable to the adjustment endeavors and economic reforms in Latin American countries, which these have adopted since the mid1980s. Studies of the social effects of the adjustment measures in individual Latin American countries have shown that the negative income effects primarily affect lower income earners and thus have an adverse effect on distribution. This argument, however, is only valid for the more recent years since the beginning of the reform process in Latin America. It cannot explain the long-lasting inequality of its distribution.

5. Finally, the arguments put forward by the Inter-American Development Bank (1998) are not completely convincing. Some results seem to establish a Kuznetstype association between the distribution of income and economic development while other seem to refute it.

6. The consequences of an unequal distribution for growth and poverty are important simply because it has not been possible to clearly answer the question of whether in the course of economic development a tendency to improve distribution will emerge (Kuznets' $U$ hypothesis) or not. In the latter case it may happen that high inequality causes low growth rates implying that poverty will remain high in the foreseeable future. On the contrary, if a Kuznets-type association between inequality and development can be established, income is the main determinant of poverty. In this case a policy of poverty alleviation should care for the determinants of income growth. Formation of human capital, a high investment rate, a low population growth rate and openness of the economy are to be seen as important for poverty reduction, although the latter can have negative effects in the short run. 


\section{References}

AGENOR, Pierre-Richard / MONTIEL, Peter J. (1996)

Development Macroeconomics. Princeton.

BARRO, Robert J. (1991)

Economic Growth in a Cross Section of Countries. In: Quarterly Journal of Economics 106, 407-443.

BARRO, Robert J. / SALA-I-MARTIN, Xavier (1995)

Economic Growth. New York etc.

BIRDSALL, Nancy / LONDOÑO, Juan Luis (1997)

Asset Inequality Does Matter: Lessons from Latin America. Inter-American Development Bank. Working Paper Series 344.

\section{BULMER-THOMAS, Victor (1996)}

The New Economic Model in Latin America and its Impact on Income Distribution and Poverty. Houndsmill and London.

CARDOSO, Eliana A. / FISHLOW, Albert (1989)

Latin American Development 1950-1980. NBER Working Paper 161.

CHEN, Shaohua / DATT, Gaurav / RAVALLION, Martin (1994)

Is Poverty Increasing in the Developing World? In: Review of Income and Wealth. Series 40, 359-376.

CLINE, William (1975)

Distribution of Income and Development: A Survey of Literature. In: Journal of Development Economics 1, 359-400.

DEININGER, Klaus / SQUIRE, Lyn (1996)

A New Data Set Measuring Income Inequality, in: The World Bank Economic Review 10 (3), 565-591.

DEININGER, Klaus / SQUIRE, Lyn (1998)

New Ways of Looking at Old Issues: Inequality and Growth. In: Journal of Development Economics 57, 259-287.

EDWARDS, Sebastian (1998)

Openness, Productivity and Growth: What Do We Really Know? The Economic Journal 108. 383-398.

FIELDS, Gary S. (1989)

Changes in Poverty and Inequality in Developing Countries. In: The World Bank Research Observer 4, 167-185.

FIELDS, Gary, S. (1992)

Changing Poverty and Inequality in Latin America, in: Public Finance 47, 59-76. 
FILIPO, Armando di (1977)

Raíces históricos de las estructuras distributivas de América Latina. In: Cuadernos de la CEPAL.

FOSTER, James / GREER, Joel / THORBECKE, Erik (1984)

A Class of Decomposable Poverty Measures, in: Econometrica 52, 761-766.

HESSE, Helmut / SAUTTER, Hermann (1977)

Entwicklungstheorie und -politik. Band I. Tuebingen, Duesseldorf.

INTER-AMERICAN DEVELOPMENT BANK (1998)

Facing up to Inequality in Latin America. 1998-1999 Report, Washington.

KAKWANI, N. (1996)

Structural Adjustment and Performance in Living Standards in Developing Countries. In: Development and Change 26, 469-502.

LEAMER, Edward E. / MAUL, Hugo / RODRIGUEZ, Sergio / SCHOTT, Peter K. (1999)

Does Natural Resource Abundance Increase Latin American Income Inequality? In: Journal of Development Economics 59, 3-42.

LI, Hongyi / SQUIRE, Lyn / ZOU, Heng-fu (1998)

Explaining International and Intertemporal Variations in Income, in: The Economic Journal 108, 26-43.

LONDOÑO, Juan Luis (1996)

Poverty, Inequality, and Human Capital Development in Latin America, 19502025. World Bank Latin American and Caribbean Studies. Washington.

LONDOÑO, Juan Luis / SZEKELY, Miguel (1997)

Persistent Poverty and Excess Inequality: Latin America, 1970-1995. InterAmerican Development Bank. Working Paper Series 357.

LONDOÑO, Juan Luis / SZEKELY, Miguel (2000)

Persistent Poverty and Excess Inequality: Latin America, 1970-1995, in: Journal of Applied Economics, Vol. III; 93 - 134.

LÜTHI, Ambros P. (1981)

Messung wirtschaftlicher Ungleichheit. Lecture Notes in Economics and Mathematical Systems. Economic Theory. No. 189. Berlin, Heidelberg, New York.

MANKIW, N. Gregory / ROMER, David / WEIL, David N. (1992)

A Contribution to the Empirics of Economic Growth. In: Quarterly Journal of Economics 107, 407-437. 
NELSON, RICHARD R. / SCHULTZ, T. PAUL / SLIGHTON, ROBERT L. (1971)

Structural Change in a Developing Economy. Colombia's Problems and Prospects. Princeton.

RAVALLION, Martin (1995)

Growth and Poverty: Evidence for Developing Countries in the 1980s. Economics Letters, Vol. 48, 411-417.

RAVALLION, Martin / DATT, Gaurav / VAN DE WALLE, Dominique (1991) Quantifying Absolute Poverty in the Developing World, in: Review of Income and Wealth, $37 \mathrm{Nr}$. 4, 345-361.

SAUTTER, Hermann / SCHINKE, Rolf (1994)

Los costos sociales de las reformas económicas. In: Contribuciones 1, 7-29.

SAUTTER, Hermann / SCHINKE, Rolf (1996)

The Social Dimension of the Latin American Reform Process. In: SAUTTER, Hermann / SCHINKE, Rolf (eds.): Stabilization and Reforms in Latin America: Where Do We Stand? Göttinger Studien zur Entwicklungsökonomik 3, Frankfurt, Madrid, 207-241.

SCHINKE, Rolf (1997)

Poverty and Growth: The Costa Rican Example. In: The Journal of Management and Economics.

http://www.econ.uba.ar/www/servicios/publicaciones/journall/index.html

SCHINKE, Rolf (1999)

Growth Determinants and Poverty (mimeo).

STRÜVER, Andreas (1991)

Das Arbeitsangebotsverhalten von Frauen in urbanen Zentren der Enwicklungsländer. Arbeitsberichte des Ibero-Amerika Instituts für Wirtschaftsforschung Bd. 30.

TABATABAI, Hamid (1996)

Statistics on Poverty and Income Distribution. An ILO Compendium of Data. International Labour Office, Geneva.

WORLD BANK (1990)

World Development Report. Washington.

WORLD BANK (1995)

World Data 1995. CD-ROM. 
Hermann Sautter and Rolf Schinke - 978-3-631-75369-9

Downloaded from PubFactory at 01/11/2019 05:49:21AM

via free access 


\title{
The Institutional Framework of a Social Market Economy
}

\author{
Hans Jürgen Rösner*
}

\section{The historic roots of the Social Market Economy}

\subsection{The postwar situation}

When in 1948 Ludwig Erhard abolished the general rationing system and implemented the Deutsche Mark via currency reform, he simultaneously created the basis for the introduction of a new economic order which later would be called „Social Market Economy” (SME). The theoretical foundations of this concept had already been laid in secret meetings of German economists during World War II and its name was introduced in 1946 already by the German economist Alfred Müller-Armack (1901-1978). The main idea and conceptual guideline was to design the institutional frame for an economic and social order in postwar Germany that would combine personal freedom and social justice. The economists who so-to-say invented the SME concept have been influenced by two schools of economic teaching namely the neoliberals and the ordoliberals. Confronted with the chaotic reality in the defeated and economically devastated postwar Germany, it deamed them quite out of way to revert to the ideal of neo-classical economics. In absence of a reliable and competitive national currency, the removal of price freezing and the dismantling of wage controls was regarded as hazardous (Gutmann,1991, pp. 13-15). Even among economists, many were convinced that still for many years rationing laws and the allocation of scarce resources would have to remain in the hands of public administration. After the sad experiences with the World Economic Crisis of 1929-1931 also public opinion was strictly against any return to market regulation not to speak of laissez-faire liberalism. Much more, many Germans would have favoured a more leftist political regime with strong corporatist elements as it has been the case during the short period of the Weimar Republic. The political outcome of the first postwar elections revealed the precarious situation advocates of market regulation, like Ludwig Erhard, would have to face and it was by no means certain that they would keep the uphand against strong socialist wings within nearly all political parties of that time (Rösner, 1990, pp. 103-133). In front of these political and economic adversities, it was probably more opportune not to refer too openly to neoliberal thinking but more to the ordoliberal tradition.

* Seminar für Sozialpolitik, Universität zu Köln, Albertus-Magnus-Platz, 50931 Köln. 


\subsection{The German school of Ordoliberalism}

Ordoliberalism is deeply rooted in a particular perception of Germany's economic and political history. Economic liberalism of laissez faire during the German Reich of 1871 has led to a concentration of private economic power which had gradually transformed the political arena into a corporatist system dominated by huge conglomerate companies mainly of the steel and mining industry. After the defeat in World War I, the weak governments of the Weimar Republic (1918-1933) were not able to contain sectional interests and political radicalization resulting in growing interventions, often leading to self-perpetuating spirals of intervention which destroyed by and by the functioning of the market mechanism. Thus, the state fell prey increasingly to different interest groups. The inefficiencies and inflexibilities resulting from the often difficult decision making under corporatist preconditions delayed Germany's recovery from the Great Depression of the years 1929 to 1932. And this prepared the ground for the final and ultimately fatal concentration of all economic and political power in the hands of the totalitarian Nazi regime (Watrin, 1979, pp. 406-409).

The full employment policy of public works and monetary expansion which the Nazis adopted from 1933 onwards was initially quite successful in bringing down mass unemployment and hence very popular, but already in the year 1936 a general wage and price freeze had to follow to prevent a surge in inflation. These measures were only a harbinger of the restrictive system of central administration that was soon to follow. In the eyes of the ordoliberals, it was both the lack of adequate safeguards against the power of interest groups and the weakness of the state which had caused the replacement of economic and political freedom by an unrestrained dictatorship.

Being liberals in the classical European meaning of a political philosophy which confides in the superiority of decentralized coordination of economic and social activity; the ordoliberals emphasized individual freedom as the overriding principle for societal organization. For them, the key to the preservation of personal liberty was to prevent any concentration of political or economic power. In the political sphere, the classical separation of power in legislature, executive and judiciary was meant to serve this purpose; and in the economic sphere, to secure intense competition of free markets was considered as the assigned task of the government. Hence, the German ordoliberals demanded more than the minimal state of laissez-faire liberalism. They explicitly advocated a strong state as impartial and incorruptible arbiter against short-term interventionism and capable of establishing and maintaining a competitive economic order without trying to centrally administer the complexity of a modern economy. 


\subsection{Constitutive and regulative principles}

The ordoliberals argument against interventionism and for general and durable rules is based on the insight and experience that selective and arbitrary interventions provoke distortions which tend to undermine the entire economic order. This thinking in terms of institutional settings or frameworks, this emphasis on the question of how any measure affects the entire interdependent order system is one of the characteristic hallmarks of ordoliberalism. Ordoliberals were also profoundly sceptical of unrestrained evolutionary processes of any kind and advocated safeguards to ensure unrestrained competition. For Walter Eucken (1891-1950), one of the leading protagonists of ordoliberal thinking, the economic order was a morphological formation characterized by constitutive and regulative principles which the state should put into action (Eucken, 1952, pp. 124-126). To maintain a well-functioning price mechanism based on the highest possible degree of competition was considered as the most important and basic task of government action. All other constitutive principles of the competitive order are no more than an outflow of this general requirement. In so far as one can say that at least some of these principles shape and distribute rights of disposal, their implementation come near modern property rights theory if interpreted as decision making rights.

1. Monetary stability is to ensure that price signals are not affected by inflationary distortions.

2. Open markets to increase competitive pressure and to thwart attempts to rent-seeking by closing markets.

3. Private ownership of the means of production to stimulate efficient use of resources.

4. Freedom of contract to give economic agents the opportunity of choice.

5. Unrestricted liability for the consequences of economic decisions to promote economic responsibility and also to internalize external effects of production and to link individual self-interest to the common welfare.

6. Continuity of economic policy to render government behaviour more predictable and to reduce the margin of error as well as the cost of uncertainty in the decisions of private economic agents.

In accordance with the role of government as arbiter of competitiveness, the ordoliberals advocated interventions or regulative principles to correct unwarranted developments of market coordination. Besides the task to ensure competition and to regulate monopolies where they are unavoidable, Eucken pleaded for progressive income taxation as an acceptable and to some extent desirable means of social policy and for minimum wages set by the government in times of recession if the labour supply reacted reverse, what means that after a decline of wages the supply of labour rises. And, finally, principles of social 
compensation for eventual failures and functional deficits of the market mechanism.

According to Eucken, the state should also, to some extent, go beyond a ruleorientated policy and interfere with the market process to affect outcomes. As was specified by Wilhelm Röpke, interventions should correct the outcomes of the market process, for example through direct transfers or subsidies, but government should not interfere with the market mechanism itself by fixing prices or quantities. Thus, all possible kinds of intervention should follow the principle of conformality, meaning that they should be handled in a way of least interference in the market process.

\subsection{The main characteristics of SME}

While ordoliberalism is the commonly used expression for the underlying set of ideas, the term Social Market Economy became the brandname for the actual economic order of West Germany after monetary reform in June 1948. The meaning behind the attribute 'social' to a market economy remained somewhat obscure, however, and drew a lot of criticism from the side of the ordoliberals and neoliberals as well. While Eucken and most other neoliberals of the Freiburg Group saw little need for a social policy that went beyond establishing a competitive order with a limited redistribution of income by progressive taxation and some basic welfare provisions, Müller-Armack and others called for a much more comprehensive and outcomeoriented approach to the 'new social question', arising from the aftermath of the lost war. So while SME certainly adopts main elements of neoliberal thinking in so far as market coordination of economic activities is considered superior to central planning from the side of the state, it distinctively diverges in two important restrictions applied to the free play of market forces:

The first fundamental divergence from neoliberal convictions consists in its different understanding of the role of the state. While neoliberals insist that the state has not to interfere in the interplay and outcome of the free market economy, in a SME the state has to perform the strategic task to provide and maintain the institutional framework between the economic and social order and the political order of the state. And the second fundamental divergence from neoliberal thinking stems from the firm conviction that the forces of free market capitalism alone are not considered appropriate to perform a distribution of production results and income that can meet the criteria of social justice. In that the market mechanism follows the biblical principle that those, who have, should be given, it is in need of corrective measures to overcome the imperfections of a competitive order which in reality is often not based on equal opportunities of participation. It is the Achilles' heel of neoliberalism that considerations of social justice apart - it is not even capable of guaranteeing the commensurability of reward and merit, as its protagonists so often maintain (Rösner, 1995, 41). The dominance of the principle of individual freedom in a 
liberal economic order therefore requires corrective countermeasures against undesirable outcomes like, for instance, a concentration of income or income disparities which are not result of personal achievement or entrepreneurial initiative alone. But what does ,social justice“" really mean and what are its implications?

Friedrich von Hayek once called it a weasel word of no identifiable meaning or practical use. This criticism is correct in so far as the market mechanism itself is blind to values and consequently incapable of distinguishing between the societally desirable and the undesirable consequences of distribution. Therefore, any decided advocate of economic liberalism, as von Hayek had been, would reject demands to chain the market to other than egoistic goals. In their eyes, just as ethics and economics are difficult to reconcile, the amalgamation of market economy and the adjective 'social' seems to represent a contradiction that is impossible to resolve. However, the intellectual fathers of SME had no intention to interfere directly with market coordination because they were strongly convinced that its superior functional efficiency would then suffer. Their solution lies in the differentiation between intervention in the market process and intervention in the market results. For this, they followed two assumptions: first, that distributive results can be corrected to conform social requirements; and second, that institutional frames and restrictions can be created to keep the market's destructive influences on society and ecology in check. This was to be achieved, for example, by confronting the economic order with a social order and institutional constraints that keep them both in balance. The application of the principle of subsidiarity should ensure that individual freedom conforms to the requirements of societal solidarity (Rösner, 1995, 45).

Following the postulate of social justice requires, therefore first, to treat equal things equally and unequal things according to their specific nature and character. And secondly that in order to promote equal opportunities of participation, excessive social inequality should be avoided. Consequently, the model of SME demands for a social security system complementary to the market process in order to encourage individuals to develop creative abilities and to take over financial risks instead of suffocating productive initiatives. By ways and means of social policy a reasonable middle path should be defined between individual risk provisions and its limitations, as for instance, in the case of illness or unemployment, where subsidiary assistance by societal security institutions must be given. A SME may be described as permanent search for the appropriate design of institutions and policies to encourage both an efficient production of means of material well-being and personal freedom in a socially-balanced order (Watrin, 1979, 419). 


\section{Differences between Welfare State and Social State}

It is useful, in this context, to note the not only semantical differentiation between the Anglo-American term „Welfare State” and the German term „Sozialstaat" or, respectively, „Social State”. Behind this lies a different concept of the role of the state in relation to the procurement of individual means of subsistence as well as a diverging perception of the scale and scope of the individual's responsibility to undertake necessary provisions against social risks.

Following the well-known definition of Asa Briggs, the Welfare State is characterized as a state, ,in which organized power is deliberately used (through politics and administration) in an effort to modify the play of market forces in at least three directions - first, by guaranteeing individuals and families a minimum income irrespective of the market value of their work or their property; second, by narrowing the extent of insecurity by enabling individuals and families to meet certain "social contingencies” (for example, sickness, old age and unemployment) which lead otherwise to individual and family crisis; and third, by ensuring that all citizens without distinction of status or class are offered the best standards available in relation to a certain agreed range of social services" (Briggs, 1961, 228). In distinctive contrast to this perception of the role of the state, „the German social state was not set up originally to realize welfare but to secure social insurance against the definable risks of illness, work accidents and unemployment as well as for old age pensions. It was not designed to provide for „general social welfare” (Koslowski 1997a, 337).

The genesis of state-organised social security institutions in Germany as in many other European countries was triggered by industrialisation and urbanisation, accompanied by acontinuous growth of citizens depending on the labour market. In addition to that, the changing family profile increased the need for new social security measures. In Germany, the state Prussia tried already in the middle of the 19th century to stabilise and to extend industrial workers' organisations for mutual help in case of sickness. Occupational schemes, mostly for white collar workers but also for miners, were formed and many voluntary self-help organisations but they never reached a general coverage. The most important step in the worldwide history of state-organised social insurance was triggered by the intention to politically pacify the labour movement when the chancellor of the German Reich Bismarck introduced compulsory social insurance with his famous legislation of the year 1881. The Workers' Health Insurance Act was introduced in 1883, the Work Accidents Insurance Act followed one year later and in 1889 the Disablement and Pension Insurance Act passed the German Reichstag. In the year 1911 the three legislations were amalgamated and laid down in the Reich Insurance Code. Thus the worldwide first system of compulsory social insurance with general coverage for all blue collar workers was established. Unemployment was not included in this legislation, as in that time unemployment benefits were paid by the trade unions 
for their members. It was not before the year 1927 that a public labour market administration was established which integrated public works programs and compulsory unemployment insurance. All these fundamental decisions concerning social insurance were made by state legislation, but the principle of self-administration was taken over from the much older mutual help organisations and applied in an altered form to the state-organised system (Ritter, 1991, pp.61-102). The Bismarckian Model was never intended as one to achieve a general redistribution of income or to introduce socialist welfare but meant the implementation of a still very modest and limited system of statutory social insurance for workers based on individual contributions. It aimed at an indispensable degree of solidarity in times of need to finance minimal insuredness against the new risks arising from the industrial society and of the industrial mode of production, and its goal was the social integration of the „working class" (Koslowski, 1997b, pp. 126-131). The fundamental principle of the Social State is subsidiarity, meaning that the priority of who has to care for the prevention of existential risks is that first the individual has to take care of himself and his family and only if this is for whatever reasons not possible, then social assistance will set in - not to replace private provisions for social security but to complement them (Rösner, 1995, pp. 39). In the following section will be discussed how the design of societal institutions can help to make the principle of subsidiarity effective.

\section{About the strategic role of institutions}

\subsection{What institutions are like}

Following Douglass North, institutions can be defined as „humanly devised constraints that structure political, economic and social interaction and they exist to reduce the ubiquitious uncertainty arising from that interaction" (North, 1991, 97). Institutions are, therefore, in first place, constraints in the form of rules like for instance laws and other regulations, and in the form of organisations like for instance law courts or administration bodies of the state. And institutions are being introduced to shape the interactions between the different members of society, or, in economic theory, between economic agents, with the general aim to reduce uncertainty in order to minimize transaction costs arising from unperfect information. The German term Ordnungspolitik, which can roughly be transcribed with the term ,institutional policy", is essentially a matter of formulating and carrying into effect basic principles for the imposition of such constraints on economically relevant disposition rights.

This leads us to the question of what do we want and expect from the institutional arrangements of our society or, put in other words, to the tasks and challenges of constitutional constructivism. If we accept that the deliberate agreement among all parties concerned should be the relevant normative 
criterion for the invention and implementaton of the institutional rules of society, it is quite obvious that only behind a veil of uncertainty (John Rawls) over the precise distributional setting, an unanimous agreement on general and durable rules is conceivable. In a given situation, however, in which the major distributional consequences of any such a decision are known, it is not. So we have to find a compromise between the different interests and power groups within society. Furthermore, ordoliberal thinking reminds us to observe the postulate of order conformity in the construction of the institutional framework of the political (or resp. legal), social and economic order of our society. Order conformity is a necessary precondition of successful societal designs because these orders are not only interdependent of each other, but are also inextricably linked by a feedback loop. The effects of these feedbacks can be positive or negative. If positive, they may give rise to synergetic interaction which enhance the level of political, economic and social performance that is attainable; if negative, such feedbacks may cause internal contradictions which may eventually lead to functional self-incapacitation or even self-destruction. This being so, societal orders will be all the more successful as they progressively eliminate incompatibilities from the functional interaction of their constituent orders. Accordingly, order conformity demands that societal institutions should be designed so as to ensure that firstly, positive feedback is generated within each constituent order to enhance the efficiency and effectiveness of the whole, and that secondly, negative feedback caused by the incompatibility of single elements between the various constituent orders is avoided. One example of such incompatibilities would be an attempt to integrate elements of a command economy, like for instance wage or price controls, in a market economy order. Conversely, the example of the former Soviet Union shows quite clearly that any attempt to install isolated market economy elements in an essentially centrally administered economy is doomed to failure as well. Instead of positive feedbacks and synergetic interaction, what we get is order components functioning according to either market or command principles and creating a great deal of friction. 
Figure 1: The magic triangle of societal designs

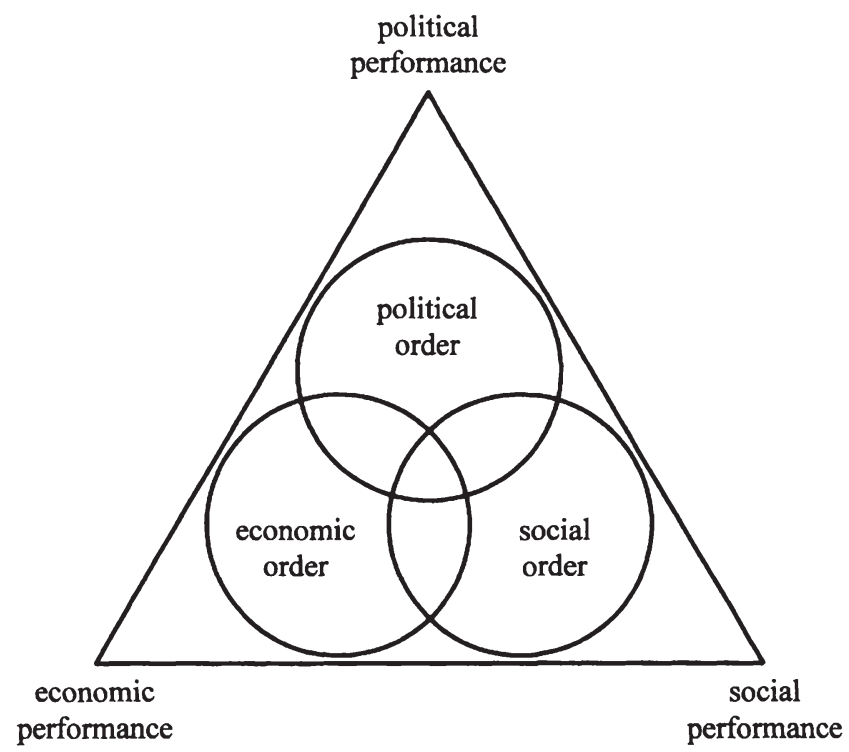

\subsection{The institutional framework of societal designs}

Therefore, in a successful societal design (see the graph), the institutional framework of orders must obey the same rules. The guiding maxims and procedural principles must be compatible with those of the other constituent orders to avoid negative feedback. The success of societal order designs can be characterized and measured by criteria of political, economic and social performance. Examples of such criteria are political stability and democratic participation, levels of employment and social security, living and education standards, social cohesion and non-marginalization as well as ecological sustainability. Though, following different priorities given to societal values like freedom, solidarity and equality, a wide range of designs seems possible, contemporary experiences show that as a common precondition institutional arrangements based on market economy and constitutional democracy obviously produce more favourable results than others. In accordance with the predominant value orientation within the society, the scale of options in this reaches from American market economy liberalism via Western European social state concepts right down to Scandinavian welfare models. 
Over time and specific historical backgrounds, institutions have been created and employed together with other mechanisms for coordination and communication between the different political, economic, and social actors for the allocation of resources, and for solving societal problems. Degrees and styles of state intervention in society and economy may differ, as does the role of interest associations in public policy and market ordering. Not to forget that in this, as Douglass North once remarked, also „history matters. It matters not just because we can learn from the past, but because the present and the future are connected with the past by the continuity of a society's institutions" (North, 1990 , VII). Typical is that most countries have combined various coordination principles and that this diversity has increased the variety of structures of socioeconomic coordination. Whereas the American economy is dominated by the principle of market individualism and the Japanese by that of communitarian collectivism, European nation-states have during their long histories developed a combination of principles which fits in between these extremes. These mixtures reflect both the opposing values of individualism and collectivism, of universalism and particularism, of hierarchy and equality and of differentiation and integration. Common is also an emphasis on concertation, cooperation and consensualism in interaction among political, economic and social actors, as against the adversarialism dominant in the US. At the same time, consensualism has not gone so far as in Japan where public debate or conflict is hardly legitimate.

In Germany, the SME understands itself as an ,irenic" or peace giving order (Müller-Armack) and has often produced balance and moderation in public and private policies and regulations in between extremes of adversarialism as well as consensualism. And what is perhaps even more important, following the principles of SME has also allowed the German society to respond - for many years - in a rich variety of ways and means to new challenges and it has provided possibilities for mutual learning and experimenting in socio-economic decision making. While the coordination of economic activity and allocation of resources is primarily done through the market in this conception, many institutional forms of coordination exist at the intersections between all three different orders of society and also at different vertical levels of aggregation as well. All together, they mean rules and restraints for the exercise of power as well as voice and partnership in political decision-making to promote effective and good governance.

\subsection{Horizontal and vertical power-sharing}

The principle of separation of power, for example, materializes not only in the traditional horizontal segregation of juridical, legislative and executive power but also in the separate jurisdiction of the federal social court, the federal labour court, the federal administrative court and, finally, the federal constitutional court. A vertical segregation takes place between federal government, the 
goverments on the level of the federal states and municipal self-administration as well as in a multitude of autonomous opinion building and decision making institutions at the micro-level of enterprises or workplaces or families; at the meso-level of associations, sectors or regions; and finally at the macro-level of the national economy and the overall state administration and they are located in between all intersections of the political, the economic and the social order. The main task of all of these institutions is to function as an arbiter of government policies but also to promote societal cohesion by strengthening the feeling of solidarity and community responsibility amongst different groups and sectors of the population. One example for this consists in the municipal self-administration of the German system of social assistance and social work in which also voluntary social welfare organisations play an important part in that they exercise public functions on their own responsibility and self-determination. Voluntary organisations have even been given constitutional priority over public institutions in the case of social welfare and youth welfare in order to ensure a partnership-like collaboration between public and private institutions for the benefit of persons in need of social assistance (Jarré, 1995, 183). With this kind of functional decentralization not only the principle of subsidiarity is put into practice but it manifests also a living example for the commitment of individual citizens to participate in self-help and self-responsibility social activities.

Another example for institutionalized power-sharing lies in the important role that employer organizations and trade unions play in state-free collective bargaining. In the concept of SME, both parties are supposed to act as so-called social partners meaning they should cooperate in a way that social peace in labour relations is assured. Though the social partners can be integrated as mediators of labour and capital interests in the formulation and implementation of government policies, this 'concertation' should not be misinterpreted as corporatism as it is not firmly institutionalized but takes place only in the form of casual meetings and round table discussions. Furthermore, the social partners form part of the self-administration bodies of the institutions of statutory social insurance, which are organized as public law corporations independent of the state and are managed jointly by freely-elected employer and employee representatives cooperating with representatives of public authority.

\section{Lessons from the German experiment}

When it was said before that the German system of mandatory social insurance for blue collar workers was established more than a hundred years ago, it should also be quite obvious that there have been no historical links with the SME which was introduced nearly 70 years later. As there are many ways and means to organize social security, the intellectual fathers of this concept probably would have liked to have greater choice in this but a system which has grown over so many years is resilient to fundamental change. It has become part of the German cultural heritage. Nevertheless, meanwhile profound structural changes 
in the economic and societal environment have taken place. Technological progress and a changing perception of the family model have led to different lifestyles and working conditions.

Making choices about the structure and level of safety net programs is always a tough choice in that it inevitably involves both trade-offs among conflicting values and a great deal of uncertainty. Furthermore, expectations among the population concerning the scale and the scope of social provisions have become more and more demanding making it very difficult for any politician to introduce cutbacks. One can say that the expansion of public social benefits is like squeezing out toothpaste: it is rather easy to get out more but nearly impossible to get it back in. What was originally designed to bridge temporary spells of missing income, over time has become the mainstay over many years for a growing number of people and sometimes the basis for an unemployed lifestyle. So while personality, subsidiarity and solidarity as fundamental guidelines of the social dimension of SME have stood the test of time, one also has to admit that the nets of social security have quite often been knit together more or less erratically and are far from being logical consistent.

Besides the problem that efficiency, effectiveness and transparency in the implementation of social provisions are often missing, according to the concept of SME, social policy and economic policy should be viewed as complementary to each other. Complementarity means that economic policy measures should also serve social goals as, for instance, in that they create income and access to social insurance. On the other side, social policy measures should also serve economic goals in that, for instance, they promote health, education and employability. But, regrettably, this is not always the case in the German social security system as it presents itself today.

The phenomenon of persistent mass unemployment presents a clear case that something must have gone wrong with the German model. The application of the SME concept, for so many years synonymous for economic growth and full employment, has lost some of its fame as other countries seem to be more successful in tackling present economic challenges. Many (mostly neoliberal) economists strongly believe that the German net of social provisions is overextended and that overly generous rates of income replacement have raised reservation wages to levels reducing the incentives to work. As well, strong trade unions have made it impossible to lower wages in accordance to changes of individual productivity levels, so that many blue collar workers with lower skills have lost their jobs. And, finally, another reason for the unemployment syndrome lies in the very roots of the Bismarckian model of social insurance which was originally constructed for the single male breadwinner who had to support his family through continuous full-time work. It so-to-say followed the family principle of social insurance. The orientation on a very traditional bread winner model of family made it necessary to concentrate the whole burden of contributions for social insurance on working income. Today, 74 percent of total 
social expenditures are financed through workers' and employers' contributions, and these contributions presently amount to about 42 percent of nominal wages. This „wedge" of social contributions (besides taxes) is not only driving nominal wages and net income more and more apart but makes regulated employment often too costly.

At the lower end of the pay scale, however, things are very different. Here, relatively generous and continuous social assistance payments define the floor below which net wages cannot be reduced. Thus, certain types of "bad jobs" which may be socially tolerated in the United States or in Great Britain, would not be accepted in Germany. The reason for this lies in the fact that - contrary to the family principle of social insurance - the current provisions for social assistance are granted as a general human right and consequently in form of individual entitlements. This means that larger families, at least in some cases, can get more net income from the accumulation of their personal entitlements for social assistance than they would get from breadwinner's regular work alone.

Another corroding factor for the family principle lies in the simple fact that more and more families are falling apart what creates additional reasons but also incentives to claim social assistance benefits, often as a supplement to income from part-time work. The ongoing decomposition of the traditional model of industrial work, i.e. continuous and full-time employment into a great variety of part-time jobs, contingent work, self-employment and many other atypical forms of labour will lead to a growing individualization of working lifes which could render the family principle of social insurance obsolete.

It is therefore necessary, on the one side, to shelter families from falling into poverty. Probably, a combination of wage and tax policies should be used to ensure that also low-paid full-time workers earn enough to keep their families out of the dependency from social assistance. On the other side, social policy as a whole should not exhaust itself in the passive role of handing out benefits but should play a more activating role. To face the new challenges from atypical employment, better adapted forms and provisions of social security should be developed in order to encourage work and support self-reliance to get people in a situation where they can help themselves.

What should be kept in mind, however, is that present functional deficits are not due to the malfunction of principles or deficiencies in the institutional framework of SME but to the negligence of politicians. 


\section{References}

BRIGGS, A. (1961)

The Welfare State in Historical Perspective, Archives Européennes de Sociologie, II, 2, 221-258.

EUCKEN, W. (1952)

Grundsätze der Wirtschaftspolitik; Bern/Tübingen.

GUTMANN, G. (1991)

The Intellectual Basis and Historical development of Social Market Economy, in: Jung, W. (ed.), Social Market Economy: an economic system for developing countries. Sankt Augustin.

JARRÉ, D. (1995)

Decentralisation and Subsidiarity in Welfare and Social Work - The Case of the Federal Republic of Germany, in: Lachmann / Rösner (eds.), Social Security in Social Market Economy. Conceptual Foundations and Procedural Principles, Sankt Augustin 1995, p. 179-191.

KOSLOWSKI, P. (1997a)

The Social State in the Post-Modern, in: P. Koslowski / A. Føllesdal (Hg.), Restructuring the Welfare State. Theory and Reform of Social Policy. Berlin, 337-379.

KOSLOWSKI, S. (1997b)

Origins of the "Social State" in German Philosophy and "Staatswissenschaft”, in: P. Koslowski / A. Føllesdal (Hg.), Restructuring the Welfare State. Theory and Reform of Social Policy. Berlin, 119-144.

LACHMANN, W. (1995)

The Genesis and Principles of Social Market Economy, in: Lachmann / Rösner (eds.), Social Security in Social Market Economy. Conceptual Foundations and Procedural Principles, Sankt Augustin 1995, p. 18-33.

MÜLLER-ARMACK, A. (1956)

Soziale Marktwirtschaft, in: Handwörterbuch der Sozialwissenschaften, Stuttgart/Tübingen/Göttingen, Vol. 9.

NORTH, D. C. (1990)

Institutions, Institutional Change and Economic Performance; Cambridge.

NORTH, D. C. (1991)

Institutions; in: Journal of Economic Perspectives, Vol. 5, No. 1, pp. 97-112.

RITTER, G.A. (1991)

Der Sozialstaat. Entstehung und Entwicklung im internationalen Vergleich. München. 
RÖSNER, H. J. (1990)

Grundlagen der marktwirtschaftlichen Orientierung in der Bundesrepublik Deutschland und ihre Bedeutung für Sozialpartnerschaft und Gemeinwohlbindung. Berlin.

RÖSNER, H. J. (1995)

Social Market Economy as a Normative Model of Governmental Social Policy, in: Lachmann / Rösner (eds.), Social Security in Social Market Economy. Conceptual Foundations and Procedural Principles, Sankt Augustin 1995, p. 34-53.

WATRIN, C. (1979)

The Principles of the Social Market Economy - its Origins and Early History, in: Zeitschrift für die gesamte Staatswissenschaft, Heft 3, Jg. 135, S. 405-425. 
Hermann Sautter and Rolf Schinke - 978-3-631-75369-9

Downloaded from PubFactory at 01/11/2019 05:49:21AM

via free access 


\title{
Harmonizing Equity with Growth: The Role of Educational Policy
}

\begin{abstract}
Knut Gerlach*
"The universality of this positive association between education and earnings (and between age and earnings) in one of the most striking findings of modern social science"
\end{abstract}

(Blaug 1973, 27).

\section{Introduction}

This paper, firstly, presents evidence on the effect of education on earnings and on the growth of Gross Domestic Income (GDP) from an empirical microeconomic and macroeconomic perspective. It analyzes why the returns to education might be higher for less advantaged individuals than for those from advantaged families. Secondly, and as an example of on-the-job training (OJT) the German apprenticeship system is investigated. The paper concludes with a brief summary.

\section{Microeconomic aspects of the private return to education}

\subsection{Mincer's Wage Equation}

In his seminal study Mincer (1974) showed that if the only cost of attending school an additional year is the forgone income, i.e. the opportunity cost of the students' time, and if the growth in earnings due to the additional schooling remains constant during the work life, then the log of earnings is linearly related to the years of schooling of an individual.

\section{(1) $\ln Y_{s}=\ln Y_{o}+r \cdot s$}

with: $Y_{0}$ - earnings after compulsory years of school

$\mathrm{Y}_{\mathrm{s}}$ - earnings after $\mathrm{s}$ - additional years of school

$\mathrm{s}$ - additional years of school

\footnotetext{
* Institut für Quantitative Wirtschaftsforschung, Fachbereich Wirtschaftswissenschaften, Universität Hannover, Königsworther Platz 1, 30167 Hannover.
} 
$\mathrm{r}$ - rate of return to investment in schooling.

In empirical investigations equation (1) is usually formulated as:

$$
\ln Y=\beta_{o}+\beta_{1} \cdot s+u
$$

with a disturbance term $\mathrm{u}$. The coefficients $\beta_{o}, \beta_{1}$ are determined by techniques of regression analysis.

Subsequently, Mincer augmented his model to incorporate returns to OJT:

$$
\ln Y=\beta_{0}+\beta_{1} S+\beta_{2} X+\beta_{3} X^{2}+u
$$

with $\mathrm{X}$ as work experience, which is usually measured as age minus education minus 6 , and $X^{2}$ as experience squared.

Mincer's formulation emphasizes that years spent in school and not degrees or certificates are the key determinants of earnings. Consequently, years of schooling in countries with different systems of education can be used to estimate and compare returns to education. Equations (2) and (3) have been estimated for a large number of countries using OLS and the estimate of $\beta_{1}$, the rate of return to education, has usually been found to be in the range from 0.05 to 0.15 (Psacharopoulos 1994). A coefficient of 0.10 means that ceteris paribus an additional year of schooling is correlated with 10 percent higher earnings.

Since the formulation of Mincer's earnings equations an enormous amount of research has tackled the question of the interpretation of the slope of the education variable (S) in equations (2) and (3).

- Does education have a positive impact on knowledge and capabilities which are relevant for jobs and are, consequently, rewarded by the labor market?

- Does the positive slope of the education variable mainly reflect the unobserved and unobservable ability and other characteristics of individuals which are strongly correlated with education?

- Is education valued in the labor market because it signals high ability of individuals (Spence 1973)?

- Would an additional year of schooling provide all individuals with the same rate of return to schooling or does the proportionate growth of earnings vary in a systematic way with individual and employment characteristics (gender, race, occupation, region, sector of economic activity, size of firms)?

Conclusive and definite answers to these questions are not yet available. The findings, however, suggest that education is not a proxy variable capturing the unobserved abilities of individuals with different amounts of schooling. This important finding is corroborated by the recent evidence from natural experi- 
ments (Angrist and Krueger 1991, Card 1995). In these studies the variations in time spent in schools, which are used to estimate the rate of return to education, are due to a known and probably exogenous source. Interestingly, these investigations show that a restriction of the variability of schooling to exogenous sources, i.e. excluding the variance which stems from individual decisions, leads to higher estimates of the return to education.

\subsection{Differences in the rate of return to human capital across groups}

An important consequence of the arguments of the previous section is that the rate of return of an additional year of schooling, which is introduced by raising the compulsory schooling level, is probably greater than the usually estimated return to education. Thus, interventions like raising compulsory schooling are especially beneficial for students from disadvantaged households, who might not voluntarily choose extra years of schooling.

There is additional evidence suggesting that the rate of return to investments in schooling is higher for young individuals from disadvantaged backgrounds:

- An increase of resources spent for schooling tends to have more beneficial effects on disadvantaged students than on students from families with higher income (Summers and Wolfe 1977).

- Pre-school programs seem to have strong, positive effects for disadvantaged children in terms of raising their earnings in the future (Barnett 1992).

- There is some evidence that students from both advantaged and disadvantaged family backgrounds make equivalent progress on standardized tests during the academic year, the latter group, however, looses ground during the summer while the first group moves ahead (Entwisle, Alexander, and Olson 1997).

- Psacharopoulos (1994) finds that the rate of return to primary schooling exceeds the pay off to secondary and tertiary education in all regions of the world. This can be interpreted in the sense that disadvantaged children obtain higher benefits from human capital investments.

- Since in many countries educational problems seem to be most acute in urban schools serving the students from low-income families, providing greater choice between schools for these families could improve educational outcomes (Murnane and Levy 1998).

Basically, the finding that returns to investment in education is higher for students from low-income families can be explained by several arguments. First, individuals from households with lower incomes might have higher discount rates (Card 1995a). Since the decision rule for choosing a level of schooling is given by equating the rate of return to education to the discount rate, disadvantaged individuals should reap higher payoffs to schooling in 
economic models. Second, lower income families find it more difficult to substitute their own resources for poor schooling resources than wealthier families in helping their children to attain, for example, an adequate level in reading. Third, it is obvious that these explanations are based on imperfect capital markets. If capital markets were perfect, lower income families could borrow the funds for investments in human capital at the market rate and the difference in rates of return to education between the two groups would tend to disappear. There is, however, a broad consensus in the literature that future human capital is not an adequate collateral for loans because of moral hazard problems. Additionally, poorer families may systematically underestimate the economic benefits of education, since one important objective of acquiring education is the improvement of information and decision making. Families with poor endowments of education and earnings capacities might be more likely to make suboptimal investment decisions concerning education.

\subsection{Social and private returns to education}

Social returns to education can exceed the private payoff. It is often assented that education, especially higher education, generates positive externalities which contribute to economic growth. Education might lead to technological progress which is not captured by private educational investment. It can increase the productivity of less educated workers collaborating with highly educated colleagues. Education might lead to positive externalities by reducing crime and welfare dependence and by stimulating more informed political decisions and political participation. Interestingly, the former positive externalities are strengthened if higher education is expanded, while the latter rely move on an expansion of lower levels of education.

Social returns to education can be lower than the private payoff, too. If education just certifies the unobservable abilities of individuals, it does not raise their productivity (Spence 1973). In addition, the extra tax revenue resulting from the increase in the number of individuals investing in higher education with subsequent higher earnings is usually not sufficient to compensate for the investment expenditure and subsidies of the state. There is evidence that in some developing countries higher education is associated with a greater incidence of unemployment and that in those circumstances the return to physical capital may exceed the return to higher education (Freeman and Lindauer 1999).

Externalities from education are important because of their role for the educational investment decisions of the state and for the question concerning the impact of human capital investments on economic growth. 


\section{Macroeconomic aspects of human capital}

\subsection{Growth and education}

Most growth theories postulate that the accumulation of factors of production, basically physical and human capital, in conjunction with the increasing productivity of these factors, determine the growth rate of an economy. Starting with pioneering work of Denison (1967) to the more recent analyses of Benhabib and Spiegel (1994) and Topel (1998) economists have investigated the role of education as an important determinant of aggregate economic growth. However, regressions associating human capital with growth across countries do not lead to unequivocal results (Barro 1997). Differences in regression results stem from the choice of the functional form of the equation relating education to aggregate growth, the incorporation or exclusion of other variables which are potential sources of growth, and especially from the inclusion of the level of human capital or its changes as regressors.

In one of the most recent studies Topel (1998) regresses growth rates on absolute, not relative changes in schooling. He finds that both the level and the absolute growth of schooling have a positive effect on growth. In addition, countries with a high initial stock of human capital seem to grow faster than other economies. It is fair to state that in most investigations investments in physical capital have a stronger and more robust impact on economic growth than investments in education.

The conclusion seems to be warranted that on the macroeconomic level investments in human capital are not a sufficient condition for achieving economic growth. Conversely, a slow development of the educational system is not an absolute impediment to economic growth. Freeman and Lindauer (1999) hypothesize "that there is a lexicographic ordering to the determinants of growth and that first and foremost is political stability and the security of property. Without this base, investments in education, openness (of the economy, K.G.), and levels of income equality have little effect on growth".

\subsection{Inequality, education and growth}

Half a century ago macroeconomists argued that inequality of income contributed to growth. In the model of Kaldor (1955-56) income inequality raised savings which stimulated investment and growth. Consequently, in the initial phases of growth an economy is coerced to accept a rising inequality.

During the past decade the academic debate has started to focus again on the relationship between growth and equity (Inter-American Development Bank 1999). According to the recent debate, a very unequal income distribution might adversely affect the rate of physical and human capital accumulation and productivity growth. In these models the role of human capital is stressed, since 
poor families are unable to finance education and, thus, future economic and social benefits are foregone.

There is some empirical evidence supporting the recent debate and contradicting the traditional view point of growth economists. Empirical macroeconomists have started to include measures of income inequality in growth regressions and found a negative impact on growth rates (Alesina and Rodrik 1994, Persson and Tabellini 1994). On the basis of a survey of twenty-three investigations analyzing the relationship between inequality and growth of GDP per capita or investment, Benabou (1996) concludes that low levels of income inequality persistently improve growth. These results reflect the divergences of growth performance between countries with high levels of inequality (Philippines and many Latin American countries) and low inequality (Korea and many East Asian countries). In addition to education as a link between inequality and growth, other factors explaining this result presumably are the increase in political and macroeconomic stability with concomitant higher growth rates of investment and GDP. Lower levels of inequality are assumed to strengthen political and macroeconomic stability and to make more feasible an economic and social policy which avoids unpredictable oscillations caused by attempts to cater to the preferences of groups with incompatible positions in the income distribution.

\section{The German apprenticeship system}

\subsection{Institutions, facts and trends}

One recurrent theme of the previous two sections was the view shared by most economists that the skills of the labor force, their human capital, is an important determinant of earnings and growth. In addition to the human capital measured by the amount of formal schooling, worker training and OJT is a second significant source of productivity, earnings and growth.

Table 1 shows that in 1995 about two thirds of all West Germans in the agegroup 30 to 35 years had an apprenticeship degree. This proportion increased from $60.4 \%$ (1976) to $68,9 \%(1991)$ and decreased slightly in subsequent years. During the same period (1976-1995) the percentage of West Germans with a university diploma rose from $9.6 \%$ (1976) to 15.6 (1995). In comparison with education in the university system apprenticeship training is losing some of its importance (Blechinger and Pfeiffer 1999).

In 1997 about 493000 young persons were seeking a training place while firms offered 487000 apprenticeship jobs and the number of new apprenticeship contracts amounted to 461000 (Table 2). It is evident from Table 2 that since 1977 the market for apprenticeship places was characterized by constellations of excess demand $(1982-1986,1997)$ and excess supply (1988-1995). The reduction of the number of new contracts can be attributed to various determi- 
nants like demographic change, the increasing enrollment rates in universities and the strong decline of the number of apprenticeship places since the severe recession after German reunification in 1992. In this period large firms, in particular, have reduced the size of their workforce and the number of apprentices (Pfeiffer 1996). About 33\% of all 1.6 Mill. West German firms were involved in apprenticeship training and approximately $90 \%$ of large firms (more than 500 employees) offered training places. The retention rates of apprentices who completed the training with success varies between $45 \%$ (small firms) and $72 \%$ (large firms) (Pfeiffer 1996).

Since most young people participate in apprenticeship training while they are 16-20 years old, youth unemployment in Germany is a more severe problem for the labor force aged 20 to 25 . In the period 1993 to 1997 the unemployment rate of young people (20-25 years) amounted to approximately $10 \%$ and was lower than in the majority of comparable countries (Table 3).

It is rather complicated to compute the costs and benefits of apprenticeship training. On average, in 1997 apprentices received a monthly remuneration of DM 1055 (West Germany) and DM 936 (East Germany) (Table 4). This payment amounts to about 25 percent of the wages of a skilled worker and it increases moderately from the first to the third and final year of training. It is considerably lower than the remuneration paid to apprentices in France and England (Table 5) and indicates that German apprentices share the costs of training with firms by foregone income.

In spite of this cost sharing apprenticeship training is expensive for firms (Table 6). Firms incurred average total gross costs per apprentice per year of about DM 30000 in 1991. Costs increase strongly with firms size. If the time and wages of part-time instructors in the firms are excluded the variable costs amount to DM 18000 . The productivity of an apprentice, valued at the wages of a skilled worker, yields on average DM 12000 . Assuming perfect markets and using full (variable) costs, the net cost of training amounts to DM 18000 (DM 6 000). If the assumption is made that wages of skilled workers are not determined in perfect markets and that their marginal productivity is two times larger than their wage, net training full (variable) costs would be about DM 6000 (- DM $5000)$. Even on the basis of this unrealistic assumption large firms would have positive training costs of about DM 7500 per apprentice per year. These computations suggest that many firms, in particular large firms, incur substantial financial costs in providing general training to apprentices (Acemoglu and Pischke 1999). The question of why they do this will be addressed in the next section.

The Vocational Training Act (1969) allows firms to train apprentices in about 400 clearly defined and recognized trades and occupations (for example auto mechanic, doctor's receptionist). For each occupation a specific training curriculum and detailed educational standards are defined. Only training in a 
defined occupation leads to an accepted occupational degree (Blechinger and Pfeiffer 1999). Perhaps the most important feature of the dual system of vocational training is that apprentices are educated as part-time students at special vocational schools and trained in the firms. Teaching at a vocational school is offered either once a week for eight hours or by forming blocks of six or seven weeks twice a year. Local authorities are in charge of vocational schools, the teachers, however, are employed by the ministries of education of the respective federal state and the ministries supervise the schools.

Firms offering apprenticeship training must fulfill several requirements, which are supervised by the chambers of industry and trade and the guilds. Instructors have to meet special qualifications obtained during an education as a master craftsman. The organization of training within firms depends strongly on the size of the firm. On-the-job training prevails at small firms and in the craft sector. Large firms have established training centers which are exclusively used for training. Smaller firms frequently send apprentices to training centers which are established and funded by the local chambers and the Federal Ministry of Education and Science. At the end of the apprenticeship an external examination in both theoretical and practical knowledge must be passed to obtain a skilled worker's certificate. The failure rate is about 10 percent. A large majority of all apprentices, about 85 percent, is trained in the industry and trade and craft sector. Although the industry and trade sector trains more apprentices than the craft sector, the latter educates young people in excess. After obtaining a degree as a skilled worker, the workers who are trained in excess in the craft sector are usually employed as semi-skilled workers in industry or other sectors of the economy.

Apprenticeship training is more attractive in the industrial and trade sector, in particular in the larger firms of that sector, than in the craft sector. Graduates, their parents and school teachers rank apprenticeships across sectors and companies and the best graduates tend to find training places in the companies offering the most attractive training, usually the larger firms. In these companies apprenticeship training is the main port of entry to an internal labor market for skilled workers. Significant advantages are associated with this route into the labor market: Employment security, wage differentials compared to employees in smaller firms (Gerlach and Hübler 1998) or to semi-skilled workers and a range of additional fringe benefits. This sorting of apprentices on the basis of their educational attainment is of great importance for their future work careers. In addition, there is strong evidence that further training, i.e. training taking place after a worker has acquired an initial occupational qualification, is offered more frequently in larger than in smaller firms and that further training correlates positively with the employees' level of qualification (Gerlach and Jirjahn 1999). Although the German apprenticeship system provides training for a substantial part of a youth cohort, it distinguishes between young people with different abilities and family backgrounds. 
Table 7 summarizes the most important institutional characteristics of the German apprenticeship system. The federal government determines the minimum standards of qualification in training and the individual federal states are in charge of the vocational education offered in schools. Employers, associations of employers, unions, teachers and state officials are involved in the design and development of apprenticeship training. This complex network, which reflects cooperative labor market institutions, encompasses the interests of most participants to vocational education. Modifications of the system, which take into account changing working conditions and skills, however, are difficult to introduce, since they require coordination and consensus of several institutions and persons. Coordinating activities are performed by the federal institute for vocational training (Bundesinstitut für Berufsbildung).

\subsection{Theoretical considerations}

Becker (1964) distinguishes two forms of OJT in human capital, namely general and firm-specific training. General training provides transferable skills which can be used in many firms, while firm-specific training leads to non-marketable skills that can only be applied in the training firm. In a competitive market firms cannot invest in general training, since they will not be able to recoup the returns to education by paying the worker less than his increased productivity. The worker can always opt for employment at a rival firm which will pay a wage equivalent to his enhanced productivity. Consequently, workers must pay for general OJT themselves through reduced wages during the period of training. Conversely, it is widely accepted in the literature that in case of firmspecific training workers and firms maximize their utilities and profits by sharing the costs and benefits of training. This reduces turnover and provides incentives for both parties to make the appropriate investment decisions in training.

It is evident that the German apprenticeship system basically promotes investment in general training. The training is occupation-specific, vocational schools teach mathematics and additional general courses, and apprentices are trained in key qualifications which can be applied in many firms (Blechinger and Pfeiffer 1999). The crucial questions, therefore, is why firms may invest in the general skills of their trainees and employees and incur substantial costs for these investments. In the literature (Harhoff and Kane 1997, Acemoglu and Pischke 1999, Soskice 1994, Franz and Soskice 1995) several answers can be found which stress imperfections in labor markets and characteristics of German labor market institutions leading firms to provide general training which is not financed by reduced wages during the training period.

German firms face high firing costs and binding wages set in collective contracts. After completion of a training program the firm can decide not to retain an apprentice without incurring dismissal costs. Apprenticeships may serve as an expensive selection and probation test for which firms are willing to 
pay. The observation of an apprentice provides information on his productivity and his ability to learn new skills (Harhoff and Kane 1997). The latter information seems to be especially valuable since the skill-biased technological progress and the diffusion of microelectronics have increased the flexibility of production and the quality of products. More complex tasks require multiple and changing skills of workers (Gerlach and Jirjahn 1999). "Since wage bargaining in Germany often regulates not only the level of earnings, but returns to tenure as well, this information on an employee's human capital production function (i.e. how an employee transforms inputs into human capital) would have value" (Harhoff and Kane 1997).

If employers can exert some degree of monopsony on their employees they will be able to recoup the expenses for general training. One form of monopsony power is due to a regional or local immobility of workers. This residential immobility is much stronger in Germany than, for example, in the US. Although the apprenticeship training conveys general skills, workers cannot apply them in rival firms, since few employment opportunities are available at an acceptable distance. In an empirical investigation Harhoff and Kane (1997) find that the number of other firms in the same county and industry has a negative effect on apprenticeship training. The willingness of firms to engage in training increases if rival firms cannot poach their apprentices.

Acemoglu and Pischke (1999) argue that asymmetric information between current and potential firms concerning the ability of young workers can explain the firm's investment in general training. Workers who are not retained after the apprenticeship have, on average, lower ability, assuming that ability and training are complements. Since it is difficult for a high ability worker trained in a larger firm to quit and signal his ability - he might then wrongly be considered as a low ability worker - the firm can retain him and pay him less than his marginal product. This difference between the wage and the marginal product enables the firm to obtain a rate of return on its general training expenses.

While the Acemoglu's and Pischke's arguments are valid for many types of labor markets, Soskice (1994) focuses on German labor market institutions. He differentiates between large and medium-sized firms and the craft sector. The explanation of apprenticeship training in the latter sector is straightforward. Soskice draws attention to the fact that for these firms the net costs of training are either zero or minimal. These overwhelmingly small companies seem to behave in a profit-maximizing way concerning their training decisions.

The large and medium-sized firms are confronted with two important restrictions of the industrial relations system. Comprehensive wage bargaining, unions pressure for wage hikes and the existence of works councils ensure that firms cannot pursue a low cost labor strategy and that management and the work force, represented by the works council, cooperate. The firm's investment costs for general training are kept low for several reasons: 
- selection of apprentices with a good educational attainment,

- relatively low remuneration of trainees,

- sharing of expenses between the state responsible for vocational schools, the chambers implementing the external examinations and the firm,

- provision of technical and organizational expertise by the chambers,

- complementarities between general and firm-specific training.

Although wages are set by region and industry through collective bargaining between unions and employers' associations, works councils and individual employers have some latitude in setting internal pay scales and in raising wages above the minimum standards stipulated in collective contracts. The wage supplements amount to approximately 10 percent of wages set by unions and employer's associations (Meyer 1995, Bellmann and Kohaut 1995). Works councils typically maintain strong informal ties to unions. Soskice (1994) argues that works councils use their impact on the internal wage structure and the level of the firm's wage to promote the employment of workers trained by the firm and they make it difficult for firms to devise "individually tailored packages to persuade workers to leave companies". This argument is plausible due to the involvement of unions in the institutional set-up of apprenticeship training, their strong links with works councils and their emphasis on a sufficient supply of training places.

\subsection{Problems}

In a recent paper Blechinger and Pfeiffer (1999) analyze the applicability of the knowledge and capabilities conveyed by apprenticeship training using three data sets from 1979, 1985/86 and 1991/92. They find that the applicability of vocational training has decreased between 1979 and 1991/92, i.e. the discrepancies between apprenticeship training and the skills required by firms are growing. The rapid introduction of computers and information and communication technologies seem to be the major determinant of the increasing skill obsolescence. Applicability, apparently, is a more acute problem for training provided by small firms and the craft sector. In addition, on-the-job investment in human capital provided by further training has increased in importance with respect to apprenticeship training.

One reason for the increasing skill obsolescence of apprenticeship training and the rising significance of further training can be found in the organizational inertia of the system. The intervals for updating apprenticeship regulations are too long and modern occupations are seldom integrated into the system. However, in the period since 1991/92 some remarkable policy changes have taken place. 14 new apprenticeship occupations were integrated into the vocational training system, four of them pertaining to the area of information and communication (Blechinger and Pfeiffer 1999) and 60 training occupations have been reformed. 
Foreign young people, most of them were born in Germany, find it much more difficult to graduate from school than their German counterparts. Consequently, they have problems to find an apprenticeship training and if they are successful, they are usually not trained in occupations and firms with above-average career prospects. About 30 percent of foreign young people do not complete successfully an apprenticeship training (Jeschek and Schulz 1999, Berufsbildungsbericht 1998).

Firms owned and managed by non-nationals participate less in apprenticeship training than their German counterparts. Only 6 percent of the companies owned by Greeks, Italians, Portuguese, Spaniards and Turks, who could be involved in vocational training, actually train young people (Berufsbildungsbericht 1998).

Finally, high unemployment and severe economic problems in East Germany have led to imbalances in the market for vocational training in the Eastern states. In 1997, about 15 percent of the young people were unable to find an apprenticeship training. The excess demand for training would have been larger without subsidies of the federal government and the Eastern federal states. The training subsidies were offered to firms and were used to establish training centers.

\section{Conclusions}

On the basis of the political stability and security of property it is likely that investments in education, in schooling and OJT, and levels of income inequality affect economic growth. Private and social returns to schooling and OJT are high, the first typically exceed the latter and the effects of primary education seem to be particularly beneficial. Comparing the micro- and macroeconomics effects of educational investments it is evident that the former have been established much more firmly than the latter. This difference can be explained by the fact that microeconomic data sets usually contain more information, a larger number of observations and are frequently available as panel data.

Interestingly, there is increasing evidence that extreme levels of inequality impede economic growth. Simple or single recipes for stimulating growth are not available, political instability and deficient or lacking property rights prevent growth. The microeconomics studies of schooling and OJT show that, first, young people from disadvantaged or minority households accumulate less human capital than their counterparts from other sections of the society and that, second, even from an economic perspective it might be beneficial to spend additional resources on their educational investments. The discrepancy between economic efficiency and growth on the one hand and equity on the other might not be as large as usually assumed. 


\section{References}

ACEMOGLU, Daron / PISCHKE, Jörn-Steffen (1999)

Beyond Becker: Training in Imperfect Labour Markets, in: Economic Journal 109, F112-F142.

ALESINA, Alberto / RODRIK, Dani (1994)

Distributive Politics and Economic Growth, in: Quarterly Journal of Economics 109, 465-490.

ANGRIST, Joshua / KRUEGER, Alan (1991)

Does Compulsory School Attendance Affect Schooling and Earnings?, in: Quarterly Journal of Economics 106, 979-1014.

BACKES-GELLNER, Uschi (1999)

Betriebliche Aus- und Weiterbildung im internationalen Vergleich, in: Timmermann, D. (ed.): Berufliche Weiterbildung in europäischer Perspektive, Schriften des Vereins für Socialpolitik, N.F. Band 267, Berlin.

BARNETT, W. Stephen (1992)

Benefits of Compensatory Preschool Education, in: Journal of Human Resources 27, 279-312.

BARRO, Robert (1997)

Determinants of Economic Growth: A Cross-Country Empirical Study, Cambridge, Mass.

BECKER, Gary (1964)

Human Capital: A Theoretical and Empirical Analysis with Special Reference to Education, New York.

BELLMANN, Lutz / KOHAUT, Susanne (1995)

Effektiv- und Tariflöhne in der Bundesrepublik Deutschland: Eine empirische Analyse auf der Basis des IAB- Betriebspanels, in: Gerlach, K. / Schettkat, R. (eds.): Determinanten der Lohnbildung, Berlin.

BENABOU, Roland (1996)

Inequality and Growth, in: Bernanke, B. / Rotemberg, J. (eds.): NBER Macroeconomics Journal, Cambridge, Mass.

BENHABIB, Jess / SPIEGEL, Mark (1994)

The Role of Human Capital and Political Instability in Economic Development, in: Baldessari, M. et al. (eds.): International Differences in Growth Rates, New York.

BLAUG, Mark (1973)

Education and the Employment Problem in Developing Countries, ILO, Geneva. 
BLECHINGER, Doris / PFEIFFER, Friedhelm (1999)

Technological Change and Skill Obsolescence: The Case of German Apprenticeship Training, in: Heijke, H. / Muysken, J. (eds.): Education and Training in a Knowledge based Economy.

BUNDESMINISTER FÜR BILDUNG UND WISSENSCHAFT (1998)

Berufsbildungsbericht, Bonn.

CARD, David (1995)

Using Geographic Variation in College Proximity to Estimate the Returns to Schooling, in: Christofides et al. (eds.): Aspects of Labor Market Behavior: Essays in Honour of John Vanderkamp, Toronto.

CARD, David (1995a)

Earnings, Schooling and Ability Revisited, in: Polachek, S. (ed.): Research in Labor Economics, Greenwich.

DENISON, Edward (1967)

Why Growth Rates Differ, Washington.

ENTWISLE, Doris / ALEXANDER, Karl / OLSON, Linda (1997)

Children, Schools and Inequality, Boulder.

FRANZ, Wolfgang / SOSKICE, David (1995)

The German Apprenticeship System, in: Buttler, F. et al. (eds.): Institutional Frameworks and Labor Market Performance, London and New York.

FREEMAN, Richard / LINDAUER, David (1999)

Why Not Africa?, National Bureau of Economic Research, Working Paper 6942 .

GERLACH, Knut / HÜBLER, Olaf (1998)

Firm Size and Wages in Germany - Trends and Impacts on Mobility, in: Empirica 25, 245-261.

GERLACH, Knut / JIRJAHN, Uwe (1999)

Employer Provided Further Training: Evidence from German Establishment Data, Paper prepared for the eleventh annual EALE conference, Regensburg.

HARHOFF, Dietmar / KANE, Thomas (1997)

Is the German apprenticeship system a panacea for the U.S. labor market?, in: Journal of Population Economics 10, 171-196.

INTER - AMERICAN DEVELOPMENT BANK (1998)

Facing Up to Inequality in Latin America, Washington.

JESCHEK, Wolfgang / SCHULZ, Erika (1999)

Schul- und Berufsabschlüsse von Ausländern: Nur langsame Annäherung an die Abschlüsse von Deutschen, in: DIW - Wochenbericht 26. 
KALDOR, Nicholas (1955-56)

Alternative Theories of Distribution, in: Review of Economic Studies 23, 83100.

MEYER, Wolfgang (1995)

Analyse der Bestimmungsfaktoren der "übertariflichen" Entlohnung auf der Basis von Firmendaten, in: Gerlach, K. / Schettkat, R. (eds.): Determinanten der Lohnbildung, Berlin.

MINCER, Jacob (1974)

Schooling, Earnings, and Experience, New York.

MURNANE, Richard / LEVY, Frank (1998)

Standards, Information, and the Demand for Student Achievement, in: Federal Reserve Bank of New York Economic Policy Review, March.

OECD (1998)

Human Capital Investment, Paris.

PERSSON, Torsten / TABELLINI, Guido (1994)

Is Inequality Harmful for Growth?, in: American Economic Review 84, 600621.

PFEIFFER, Barbara (1996)

Das Ausbildungsverhalten der westdeutschen Betriebe 1995. Ergebnisse des IAB - Betriebspanels, in: Mitteilungen aus der Arbeitsmarkt- und Berufsforschung 29, 589-606.

SACHVERSTÄNDIGENRAT ZUR BEGUTACHTUNG DER GESAMTWIRTSCHAFTLICHEN ENTWICKLUNG (1998)

Jahresgutachten 1998/99, Bundestags - Drucksache 14/73, Bonn.

SOSKICE, David (1994)

Reconciling Markets and Institutions: The German Apprenticeship System, in: Lynch, L. (ed.): Training and the Private Sector: International Comparisons, Chicago.

SPENCE, A. Michael (1973)

Job Market Signaling, in: Quarterly Journal of Economics 87, 355-374.

SUMMERS, Anita / WOLFE, Barbara (1977)

Do Schools Make a Difference, in: American Economic Review 67, 639-652.

TOPEL, Robert (1999)

Labor Markets and Economic Growth, in: Ashenfelter, O. / Card, D. (eds.): Handbook of Labor Economics, Amsterdam. 


\section{Appendix}

Table 1: Percentage of persons aged 30 to 35 with apprenticeship training or university degree in West Germany, 1976 - 1995

\begin{tabular}{|l|r|r|r|r|r|r|r|r|}
\hline year & $\mathbf{1 9 7 6}$ & $\mathbf{1 9 7 8}$ & $\mathbf{1 9 8 2}$ & $\mathbf{1 9 8 5}$ & $\mathbf{1 9 8 9}$ & $\mathbf{1 9 9 1}$ & $\mathbf{1 9 9 3}$ & $\mathbf{1 9 9 5}$ \\
\hline university degree & 9.60 & 9.82 & 12.03 & 14.01 & 15.13 & 15.16 & 15.59 & 15.63 \\
\hline $\begin{array}{l}\text { apprenticeship } \\
\text { training }\end{array}$ & 60.44 & 61.36 & 63.15 & 63.74 & 66.28 & 68.94 & 67.75 & 67.43 \\
\hline $\begin{array}{l}\text { without } \\
\text { professional } \\
\text { training }\end{array}$ & 29.96 & 28.82 & 24.82 & 22.25 & 18.59 & 15.90 & 16.66 & 16.94 \\
\hline
\end{tabular}

Source: Blechinger and Pfeiffer (1999) 
Table 2: Supply, demand and number of new apprenticeship contracts in (West) Germany, 1977 - 1997

\begin{tabular}{|c|c|c|c|}
\hline Year & New Contracts & Supply & Demand \\
\hline \multicolumn{4}{|l|}{ West } \\
\hline 1977 & 558,400 & 583,900 & 585,400 \\
\hline 1978 & 601,700 & 624,000 & 625,500 \\
\hline 1979 & 640,300 & 677,200 & 660,000 \\
\hline 1980 & 650,000 & 694,600 & 667,300 \\
\hline 1981 & 605,636 & 642,984 & 627,776 \\
\hline 1982 & 630,990 & 650,985 & 665,170 \\
\hline 1983 & 676,734 & 696,375 & 724,142 \\
\hline 1984 & 705,652 & 726,786 & 764,078 \\
\hline 1985 & 697,089 & 719,110 & 755,994 \\
\hline 1986 & 684,710 & 715,880 & 730,980 \\
\hline 1987 & 645,746 & 690,287 & 679,626 \\
\hline 1988 & 604,002 & 665,964 & 628,793 \\
\hline 1989 & 583,736 & 668,649 & 602,104 \\
\hline 1990 & 545,562 & 659,435 & 559,531 \\
\hline 1991 & 539,466 & 668,000 & 550,671 \\
\hline 1992 & 499,985 & 623,363 & 511,741 \\
\hline 1993 & 471,169 & 554,824 & 486,010 \\
\hline 1994 & 450,210 & 502,977 & 467,666 \\
\hline 1995 & 450,128 & 493,359 & 469,524 \\
\hline 1996 & 449,299 & 483,165 & 473,936 \\
\hline 1997 & 461,800 & 487,017 & 493,990 \\
\hline
\end{tabular}


Table 2 (continued): Supply, demand and number of new apprenticeship contracts in (West) Germany, 1977 - 1997

\begin{tabular}{|c|c|r|r|}
\hline Year & New Contracts & Supply & Demand \\
\hline East & & & \\
\hline 1992 & 95,230 & 98,462 & 96,449 \\
\hline 1993 & 98,951 & 101,033 & 101,869 \\
\hline 1994 & 117,872 & 119,257 & 119,386 \\
\hline 1995 & 122,646 & 123,629 & 128,212 \\
\hline 1996 & 125,028 & 126,109 & 138,849 \\
\hline 1997 & 125,689 & 126,336 & 140,920 \\
\hline \multicolumn{4}{|l}{} \\
\hline Total & \multicolumn{3}{|}{} \\
\hline 1992 & 595,215 & 721,825 & 608,190 \\
\hline 1993 & 570,120 & 655,857 & 587,879 \\
\hline 1994 & 568,082 & 622,234 & 587,052 \\
\hline 1995 & 572,774 & 616,988 & 597,736 \\
\hline 1996 & 574,327 & 609,274 & 612,785 \\
\hline 1997 & 587,489 & 613,353 & 634,910 \\
\hline
\end{tabular}

Source: Berufsbildungsbericht (1998) 
Table 3: Youth unemployment in selected countries (in \%)

\begin{tabular}{|l|c|c|c|}
\hline Country & $\mathbf{1 9 8 3 - 1 9 8 7}$ & $\mathbf{1 9 8 8 - 1 9 9 2}$ & $\mathbf{1 9 9 3 - 1 9 9 7}$ \\
\hline Denmark & $\cdot$ & 11.1 & 10.9 \\
\hline Germany & $\cdot$ & $\cdot$ & 9.3 \\
-West Germany & 9.6 & 5.1 & 8.5 \\
\hline France & 24.0 & 21.2 & 28.4 \\
\hline Italy & 28.9 & 27.9 & 32.5 \\
\hline Netherlands & 14.2 & 9.2 & 11.1 \\
\hline Spain & 45.1 & 34.4 & 42.4 \\
\hline United Kingdom & 18.4 & 13.0 & 16.1 \\
\hline United States & 14.0 & 12.1 & 12.2 \\
\hline
\end{tabular}

Source: Sachverständigenrat (1998)

Table 4: Average monthly wages of apprentices, 1992 - 1997

\begin{tabular}{|c|c|c|}
\hline Year & West Germany & East Germany \\
\hline 1992 & 924 & 628 \\
\hline 1993 & 937 & 792 \\
\hline 1994 & 1,002 & 853 \\
\hline 1995 & 1,036 & 924 \\
\hline 1996 & 1,055 & 952 \\
\hline 1997 & 1,055 & 936 \\
\hline
\end{tabular}

Source: Berufsbildungsbericht (1998) 
Table 5: Monthly wages in the first, second and third year of apprenticeship training, 1992

(in DM and as a percentage of the wages of skilled workers)

\begin{tabular}{|l|c|c|c|}
\hline \multirow{2}{*}{} & France & England & Germany \\
\cline { 2 - 4 } & \multicolumn{3}{|c|}{$1^{\text {st }}$ year } \\
\hline - in DM & 1,616 & 1,276 & 871 \\
\hline - in \% of the wage of skilled workers & 52.9 & 38.8 & 23.4 \\
\hline & \multicolumn{3}{|c|}{$2^{\text {nd }}$ year } \\
\hline - in DM & 1,785 & 1,765 & 931 \\
\hline - in \% of the wage of skilled workers & 58.5 & 43.6 & 24.9 \\
\hline & \multicolumn{3}{|c|}{$3^{\text {rd }}$ year } \\
\hline- in DM & - & - & 1,018 \\
\hline- in \% of the wage of skilled workers & - & - & 27.2 \\
\hline
\end{tabular}

Source: Backes-Gellner (1999)

Table 6: Costs of apprenticeship training in Germany 1991 (in DM per year)

\begin{tabular}{|l|c|c|c|c|c|}
\hline \multirow{2}{*}{} & \multicolumn{5}{|c|}{ by firm size (number of employees) } \\
\cline { 2 - 6 } & $\begin{array}{c}\text { all } \\
\text { firms }\end{array}$ & $0-9$ & $10-49$ & $50-499$ & $500+$ \\
\hline (A) total gross costs & 29,573 & 27,473 & 28,176 & 30,344 & 35,692 \\
\hline (B) variable gross costs & 18,051 & 13,867 & 15,074 & 20,283 & 28,197 \\
\hline (C) apprentice productivity & 11,711 & 12,221 & 11,465 & 12,099 & 10,311 \\
\hline perfect markets & \multicolumn{5}{|c|}{} \\
\hline total net costs (A - C) & 17,862 & 15,252 & 16,711 & 18,245 & 25,381 \\
\hline variable net costs (B-C) & 6,340 & 1,646 & 3,609 & 8,184 & 17,886 \\
\hline $\begin{array}{l}\text { imperfect markets } \\
\text { (50\% markdown) }\end{array}$ & \multicolumn{5}{|l|}{} \\
\hline total net costs (A- 2C) & 6,151 & 3,031 & 5,246 & 6,146 & 15,070 \\
\hline total variable costs (B - 2C) & $-5,371$ & $-10,575$ & $-7,856$ & $-3,915$ & 7,575 \\
\hline
\end{tabular}

Source: Acemoglu and Pischke (1999) 
Table 7: The dual vocational system of training in Germany

\begin{tabular}{|l|l|l|}
\hline \multirow{2}{*}{ Aim } & skilled labour force below the university degree \\
\hline component of training & \multicolumn{2}{|c|}{ Duality } \\
\hline place of schooling & apprenticeship school & vocational school \\
\hline educator & vocational trainer & college teacher \\
\hline $\begin{array}{l}\text { primary didactic } \\
\text { principle }\end{array}$ & job-oriented approach & theoretical approach \\
\hline apprenticeship rule & $\begin{array}{l}\text { training curriculum } \\
\text { (Ausbildungsordnung) }\end{array}$ & $\begin{array}{l}\text { curriculum } \\
\text { (Lehrplan) }\end{array}$ \\
\hline $\begin{array}{l}\text { constitutional } \\
\text { regulation }\end{array}$ & $\begin{array}{l}\text { Federal Government; } \\
\S 74 \text { Constitution } \\
\text { (Grundgesetz) }\end{array}$ & $\begin{array}{l}\text { Federal States (Länder) } \\
\text { §§ 30, 70 Constitution }\end{array}$ \\
\hline finance (explicit cost) & firm & public sector \\
\hline supervision & $\begin{array}{l}\text { Guilds } \\
\text { (Handwerkskammer) } \\
\text { and chambers of } \\
\text { commerce }\end{array}$ & Federal States \\
\hline Coordination & $\begin{array}{l}\text { Coordination Committee } \\
\text { (Koordinierungsausschu } \beta)\end{array}$ \\
\hline
\end{tabular}

Source: Blechinger and Pfeiffer (1999)

Table 8: Youth unemployment in selected countries (in \%)

\begin{tabular}{|l|c|c|c|}
\hline \multicolumn{1}{|c|}{ Country } & $\mathbf{1 9 8 3 - 1 9 8 7}$ & $\mathbf{1 9 8 8 - 1 9 9 2}$ & $\mathbf{1 9 9 3 - 1 9 9 7}$ \\
\hline Denmark &. & 11.1 & 10.9 \\
\hline Germany &. &. & 9.3 \\
-West Germany & 9.6 & 5.1 & 8.5 \\
\hline France & 24.0 & 21.2 & 28.4 \\
\hline Italy & 28.9 & 27.9 & 32.5 \\
\hline Netherlands & 14.2 & 9.2 & 11.1 \\
\hline Spain & 45.1 & 34.4 & 42.4 \\
\hline United Kingdom & 18.4 & 13.0 & 16.1 \\
\hline United States & 14.0 & 12.1 & 12.2 \\
\hline
\end{tabular}

Source: Sachverständigenrat (1998) 
Hermann Sautter and Rolf Schinke - 978-3-631-75369-9

Downloaded from PubFactory at 01/11/2019 05:49:21AM

via free access 


\title{
Harmonization Equity with Growth: The Role of Health Policy
}

\author{
J.-Matthias Graf v.d. Schulenburg*
}

\section{Countries have chosen different ways in financing medical care}

In most countries and societies of the world health care is considered as a special good which allocation and distribution has to meet specific regulations. Those regulations should guarantee that everybody as access to appropriate health care. The willingness and ability to pay of patients should not dictate how much and which services they receive in the case of illness. The following objectives are common for health care systems around the world:

- Equal access to health care for everyone;

- Cost-efficient production of health services;

- Effective medical care and patient management;

- Cost-control of public expenditures for medical services.

The different nations have found different solutions how to organize the financing of medical care (Table 1). Some nations employ a national health service financed by taxes, others base their health care system on social health insurance. The latter is financed by contributions of the insured and their employers. Most typical for national health service is the British system, while social health insurance schemes are sometimes called Bismarckian type systems The U.S. system is called in this overview a "muddle through (non) system". It is characterized by a health care policy which identifies certain groups in society which are under compensated or under served. For those groups special isolated programs are then created and financed by tax money. In the U.S. for instance, the Medicare program takes care for the health care of the elderly and the Medicaid program for the health care of the poor, disabled and blind. Additional programs are enacted for unmarried mothers with dependent children and for children. The risk of such a policy is the overlap of those programs and the under compensated health care for parts of the population.

Institut für Versicherungsbetriebslehre, Universität Hannover, Königsworther Platz 1, 30167 Hannover. 
Table 1: Types of health care systems

\begin{tabular}{|l|l|l|l|}
\hline & $\begin{array}{l}\text { National Health } \\
\text { Service (NHS) }\end{array}$ & $\begin{array}{c}\text { Social Health } \\
\text { Insurance } \\
\text { (Bismarckian } \\
\text { System) }\end{array}$ & $\begin{array}{l}\text { Muddle Through } \\
\text { (Non) System }\end{array}$ \\
\hline $\begin{array}{l}\text { Countries (for } \\
\text { Europe car } \\
\text { plates) }\end{array}$ & $\begin{array}{l}\text { DK, E, GB, I, IRL, } \\
\text { P, S, D (for civil } \\
\text { servants) \& most } \\
\text { DCs }\end{array}$ & $\begin{array}{l}\text { B, D, F, L, NL \& } \\
\text { Japan and Israel }\end{array}$ & $\begin{array}{l}\text { USA \& South } \\
\text { Africa }\end{array}$ \\
\hline Financing & Taxes & Contributions & $\begin{array}{l}\text { Taxes and other } \\
\text { sources }\end{array}$ \\
\hline Decision maker & Government & Decentralized & $\begin{array}{l}\text { Government and } \\
\text { others }\end{array}$ \\
\hline $\begin{array}{l}\text { Cost reimburse- } \\
\text { ment }\end{array}$ & $\begin{array}{l}\text { D (for civil } \\
\text { servants) }\end{array}$ & B, F, L, NL & $\begin{array}{l}\text { USA (most } \\
\text { programs) }\end{array}$ \\
\hline Benefits in kind & $\begin{array}{l}\text { DK, E, GB, I, IRL, } \\
\text { P, S \& most DCs }\end{array}$ & D & $\begin{array}{l}\text { USA (managed } \\
\text { care organizations) }\end{array}$ \\
\hline $\begin{array}{l}\text { Out of pocket } \\
\text { payments }\end{array}$ & Low & Moderate & High \\
\hline Cost control & Strong & Complicated & Difficult \\
\hline
\end{tabular}

The problems of equitable, efficacy and efficiency are discussed around the world. They are not singular for a certain type of system. Identical problems exist in many developing and developed countries. The financing system of health care has to take into account these goals. However rationing medical care is necessary, too. Otherwise health care cost will explode. Various measures have to be taken irrespective of the type of financing system (i.e. taxfinanced or insurance-based) to contain cost escalation and improve productivity.

In this paper a general description of several basic options for modeling a health insurance scheme is provided. Furthermore I will present an analysis of key factors influencing the choice of financing system for health care and its organization. Some factors will be explained which relate to the provision of health services and potential financial arrangements. Cost-containment or other methods of limiting the consumption of health services are particularly necessary in health systems which are based on third-party financing (see figure 1). This is regardless of whether the third-party payer is a public institution or a private body. As a result, we have a triangle consisting of patient (consumer), provider (producer) and payer (either insurance or a state institution). 


\section{Figure 1: Third party financing}

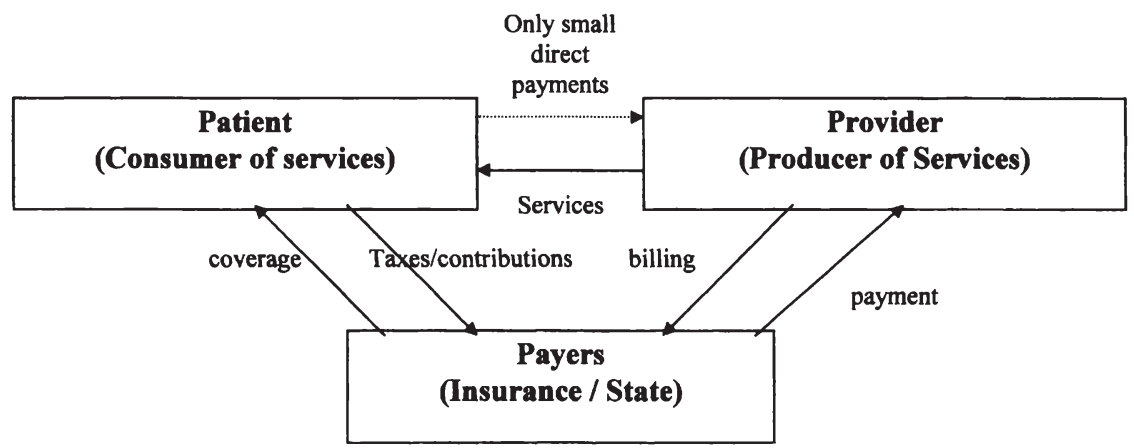

Such a system leads to the indifference of either consumer and/or producer towards the cost of treatment and the number of services provided to the patient. This phenomenon, i.e. overcompensation for treatment due to the existence of insurance and/or other third party coverage, is well known as "moral hazard".

To limit "moral hazard" out of pocket payments are introduced; that means the patient has to cover a small part of the cost of treatment (for example with copayments). Other measures include regulations directed at the providers (e.g. treatment guidelines, budgeting). The reimbursement system (the system by which payments from the payer to the provider are organized and calculated) in particular sets economic incentives for the provider to control costs.

Another important question is the respective level of centralization or decentralization in a health care system. This issue examines how the power to make decisions and delegate responsibility is distributed between various levels, i.e. national level, regional level (districts) and local level (community). In international comparison, a trend towards decentralization is to be perceived.

\section{Basic models of health care financing}

In this section, basic models of health financing systems (shown in figure 2) are explained. Whether it would be possible to establish them in specific countries and if so, how, has to be discussed.

\subsection{Private provision}

Health services can be seen as goods which are traded on more or less free markets. In this case consumers pay the provider for the full cost of the service. No special market regulations are needed for health services. However, health services have various special characteristics: 


\section{Figure 2: Basic models of health financing systems}

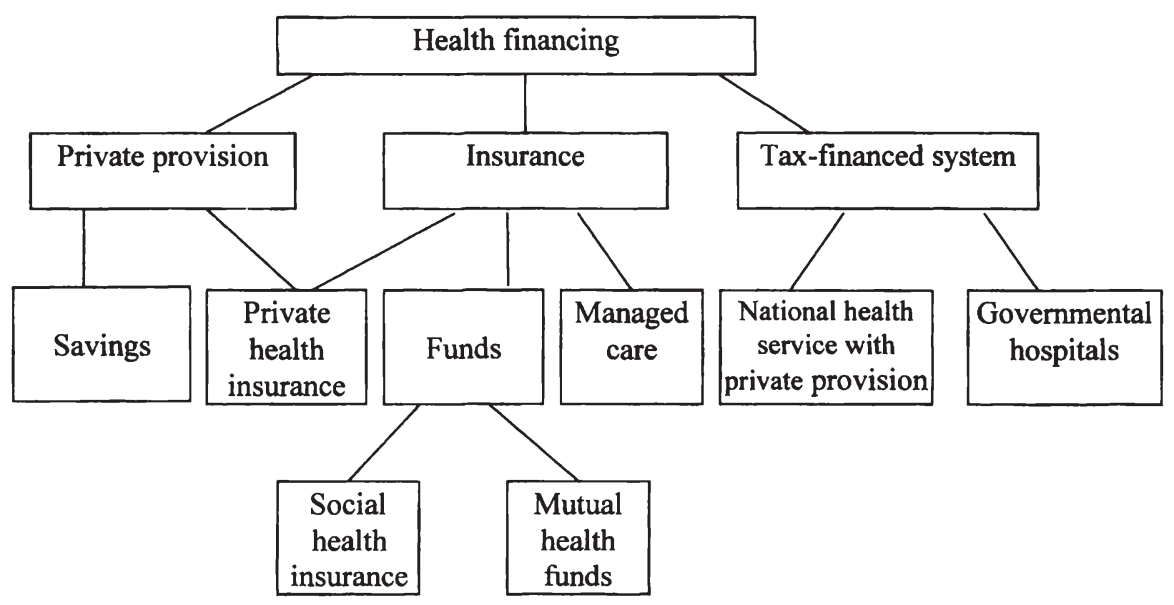

- Health services are consumed relatively seldom and therefore consumers are not very well-informed about the available alternatives or adequacy of a service for a particular problem. Their consumer sovereignty is therefore limited. They depend on the opinion of specialists such as physicians and other health care providers.

- The cost of illness is often quite high, and it is uncertain as to when health services will need to be consumed. That means that it is in the interest of most people to insure themselves to cover this uncertainty.

- Health care services are not consumed at an equal rate over lifetime or among different population groups. For this reason it might be desirable to redistribute resources across generations and social groups.

For these and other reasons (e.g. ethical reasons of equal access to essential goods like health care) the market model, where consumers pay fees to the providers which amount to the full cost of the services, is very rare and appears only on partial markets (e.g. for luxury services like beauty surgery) or on informal markets (i.e. under corruptive circumstances).

Uncertainty and ignorance about the need for health care, combined with the high cost of particular health care services often result in so-called market failure. This expression is used by economists to describe circumstances in which there are constraints on the regular order of a market. Under these conditions, private provision does not work fully and some elements of government regulation are needed.

However, the introduction of user charges can help to improve the referral system by the creation of price signals, and to increase incentives to providers. It is also the pre-requisite for the implementation of a pre-payment system, as people would not be willing to pay insurance premiums to cover the cost of 
services they previously received free. This price mechanism also limits the tendency of health insurance systems to extend the number of health services provided. Some demand is also created by suppliers of care, drugs and other medical technology. Such expenditure does not necessarily ensure that the wishes of the population for better health services are met or that political goals such as longer life expectancy or better overall health status of the population are reached.

Another type of private provision of health financing is the purchase of private health insurance with actuarial premiums (see figure 3 ). Usually this option is voluntary, but it is also possible for coverage with a private insurance company to be compulsory, but with the choice of insurer left to the consumer (such as the regulation for automobile liability insurance in many countries). Private health insurers often have only limited opportunities to contain costs and are characterized by high administrative costs (due to promotion and control costs). On the other hand, these suppliers of health coverage can usually offer highquality health care providers and a benefits package tailored to the individual needs of the citizen. These advantages are often bought with comparatively high premiums which exclude low income classes from joining the scheme.

\subsection{Tax-financed national health service}

In purely tax-financed national health services, all revenue for financing the health system is provided by the state as part of the public budget (see figure 4). Although it is not essential to this type of health financing system, all services are usually provided by public institutions such as state hospitals and health centers with employed physicians, nurses and technical staff. Private clinics or office-based physicians with their own practice are relatively rare. However, the British and Swedish national health services have stimulated private provision of outpatient services and have adopted a more decentralized structure of financing and management.

In a state-financed health system, the government or parliament can determine the balance between the amount of money allocated to the health care sector and that allocated to other essential public tasks such as defense, education and science. This leads to discussion about alternatives to health care services such as traffic safety or additional pollution control, which may also have a medical impact.

In practice it is often found that tax-financed systems are comparatively successful in controlling expenditure by powerful public control and costcontainment. On the other hand, competition in a state-financed system with public provision of services is obviously quite small. Therefore the efficiency of the system in terms of quality of care is relatively low, and efforts to assess the needs of consumers are not rewarded. On the contrary, providers who attempt to make procedures more effective risk being punished by having their budgets for the next period cut by the amount saved. 
Figure 3: Private health insurance schemes

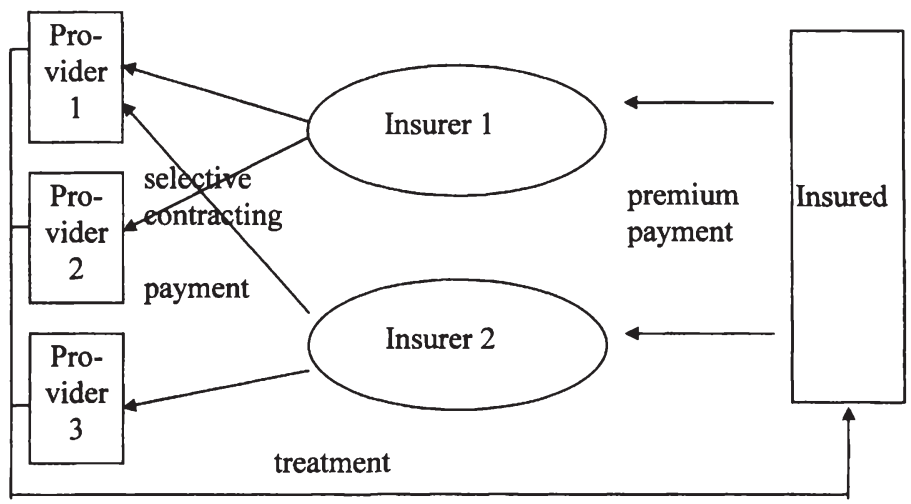

Figure 4: Tax financed health financing schemes

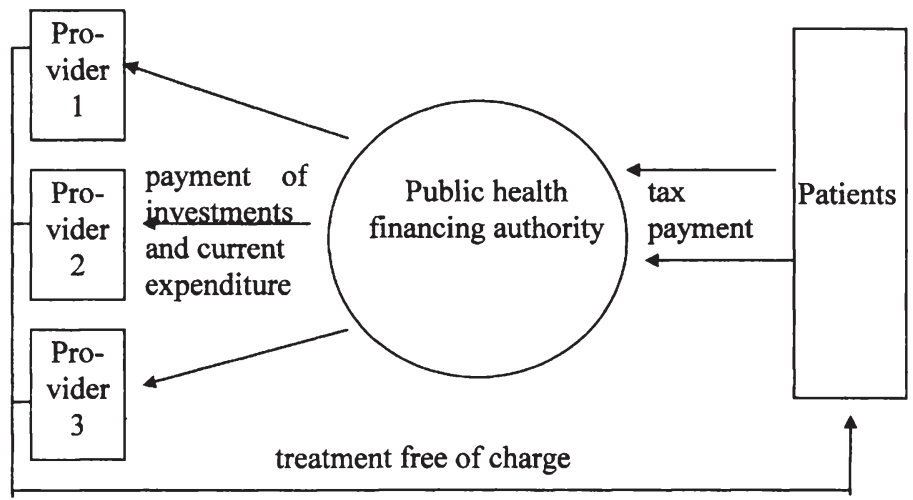

Such systems always run the risk of under funding, as the health sector is subject to political debate on its budget each year. It is highly possible that other political goals might crowd out the allocation of an adequate share for health care. As the optimal proportion of the public budget to be allocated to the health sector is not known and cannot be calculated, it has to be set as a democratic decision following public debate. But this procedure may lead to under funding and unreasonably low resources for the health system. Thus waiting lists, e.g. for elective surgery, and frustrated staff (due to low income) are quite common in such systems. 


\subsection{Statutory social health insurance fund}

The health insurance fund pools the financial contributions of its members to protect the welfare of its members should they fall ill. Without access to insurance, many people are unable to obtain treatment, or must take up loans to pay for the required medical services. Health insurance also has the potential to increase the revenue available for health care and to redistribute the burden of illness between age groups, between healthy and ill people, and between groups of different income level.

\section{Figure 5: Social health insurance fund}

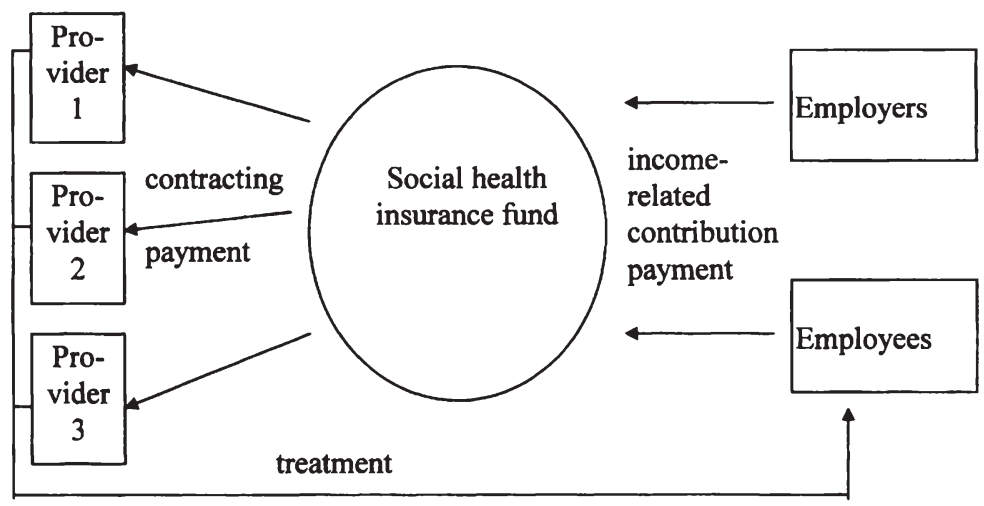

As shown in figure 5, statutory social health insurance is financed by incomerelated contributions from employer and employee. Thus the contributions are not based on risk (as the premiums of private insurance companies are), but on the ability to pay. Social health insurance systems are generally tightly regulated, but not a governmental institution. Regulation includes description of the beneficiaries, the benefit scheme, the internal organization of the fund (including responsibilities and decision-making authority), terms of financing by the contributors and payment to the providers. The benefits are usually set on a national level and the contributions are calculated to finance the total cost of these benefits.

The payroll deductions are split between employer and employee in a certain percentage (for example $50 \%$ from both as in Germany or one-third from employee and two-thirds from employer). It is intended that by this means employers will take encouraged to take some responsibility for cost-containment. One problem with this type of payroll tax is that deductions may discourage employers from hiring more employees (which would increase unemployment) and that they decrease the available income of the employee 
(which would reduce the demand for other goods in the economy). On the other hand it is often more acceptable for people to pay for health services when they discern a direct relationship between their pre-payment and the insurance benefits, rather than paying higher taxes for a national health service or a welfare program.

The division of contributions between employees and employers is a political question. It is possible for both groups to pay proportional, income-related contributions, or flat contributions which need to be adjusted periodically, or a mixed system of proportional and flat contributions as shown in table 2:

Table 2: Proportional versus flat contributions

\begin{tabular}{|l|l|l|}
\hline & proportional contribution & flat contribution \\
\hline employer & A & C \\
\hline employee & B & D \\
\hline
\end{tabular}

Proportional contributions are not necessarily superior to flat contributions and vice versa. The evaluation depends on the circumstances and the point of view of the decision maker. Pros and Cons are listed in table 3:

Table 3: Pros and cons of different types of contributions

\begin{tabular}{|l|l|l|}
\hline & proportional contribution & flat contribution \\
\hline pros & $\begin{array}{l}\text { redistribution according to } \\
\text { solidarity principle }\end{array}$ & $\begin{array}{l}\text { equal distribution of burden to } \\
\text { finance health care costs }\end{array}$ \\
\cline { 2 - 3 } & $\begin{array}{l}\text { more acceptable for lower } \\
\text { income classes }\end{array}$ & $\begin{array}{l}\text { less excess burden on wages for } \\
\text { higher income classes }\end{array}$ \\
\hline \multirow{5}{*}{ cons } & $\begin{array}{l}\text { revenues of health care plan } \\
\text { increases automatically with } \\
\text { development of wages }\end{array}$ & $\begin{array}{l}\text { strong incentive for cost } \\
\text { containment as rates have to be } \\
\text { adjusted to cover inflation }\end{array}$ \\
\cline { 2 - 3 } & $\begin{array}{l}\text { less acceptable for higher } \\
\text { income classes }\end{array}$ & $\begin{array}{l}\text { increases cost of low wage labor } \\
\text { at a higher rate than high wage } \\
\text { labor }\end{array}$ \\
\cline { 2 - 3 } & $\begin{array}{l}\text { the higher the dispersion of } \\
\text { labor the less it will be } \\
\text { acceptable }\end{array}$ & $\begin{array}{l}\text { causes problems for part-time } \\
\text { workers }\end{array}$ \\
\hline
\end{tabular}


Another disadvantage of a nation-wide social security fund is the lack of competition between various funds, which would lead to efficiency and more flexibility of administration of the social insurance. It is also unlikely that a monopoly will be able to make selective provider contracts. Instead, all providers of health care have to be offered financing from the national fund, as there is no alternative scheme. Furthermore, a deduction-financed system can only cover persons who are formally employed, i.e. the population of informal rural areas cannot be reached by this type of scheme. Furthermore, it is likely that the fund will be subjected to political pressure.

Another problem with a payment system like this one is that of volume control. As the price mechanism is interrupted (when services for members are free) or weakened (when only co-payments have to be paid) so the demand for services is likely to rise. Payment arrangements thus have to be found to establish incentives for providers and consumers to control costs.

\subsection{Mutual health funds}

In comparison with a social health insurance fund a mutual health fund is not a monopoly, but rather the citizens can choose between various public or privately administrated funds. These may be established by large industrial companies, branches of industries, trade unions or local government. As with the social health insurance fund, mutual health funds are financed by incomerelated contributions which redistribute monetary resources between the fund members according to their health service needs and ability support the fund. If necessary or desired the government may subsidize the contribution payments of low-income citizens.

The mutual health fund is a non-profit organization which can be joined by every citizen who meets the admission conditions (e.g. a certain occupation or membership of a trade union). Thus risk selection by the fund is prohibited. To avoid adverse selection in one fund it might be necessary to establish a risksharing institution (working like reinsurer) which compensates funds with a relatively bad risk structure (e.g. in terms of age, disease structure or gender) and provides services for the funds such as health fund staff-training. This organization can teach mutual health funds managers basic skills such as accounting, statistics and marketing, and can also work as a supervising agency. In order to avoid risk selection the government can also set regulations which force employees to join the employers' health fund. 


\section{Figure 6: Mutual health fund}

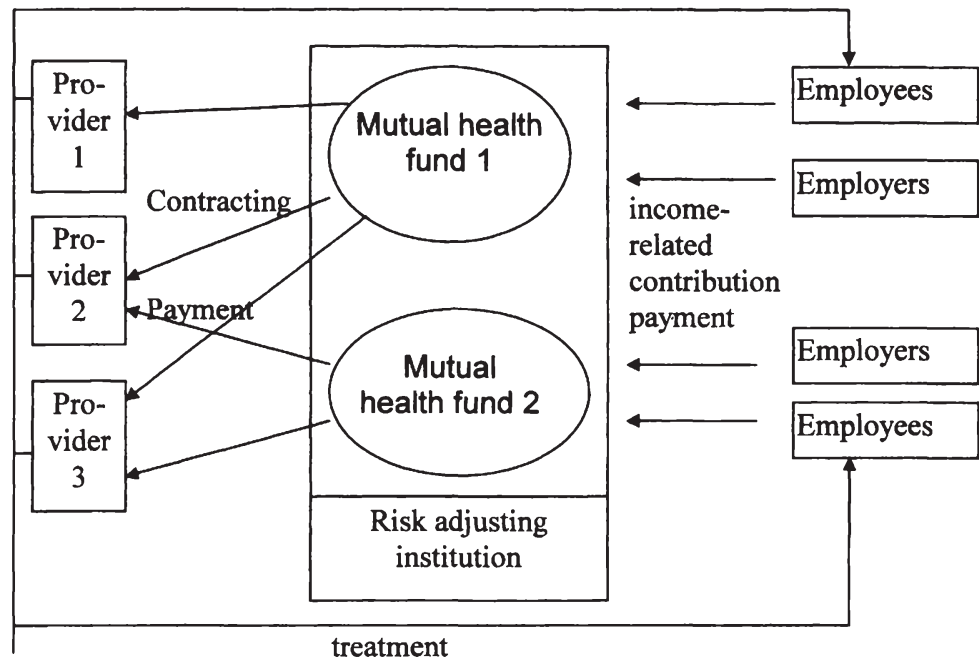

As shown in figure 6, mutual sickness funds are self-governed with a board of employers' and employees' representatives who are regularly elected by the health fund members. The board takes care for cost-containment and a high quality of services provided. It also decides on the scheme of benefits according to the needs of its insured, and on the contributions needed by the fund to finance these benefits. The health funds agree contracts with selected providers who treat the members free-of-charge (except for some co-payments to avoid an over-demand) and send the bill directly to the fund. For this it is necessary to arrange fee-for-service schedules or other terms of payment between the health fund and the providers. These are regularly reviewed and negotiated on, but have to be maintained for the term of the contract.

In some health care systems based on mutual health funds (like Germany, Switzerland and the Netherlands) it is possible for the members to opt out of the funds and to apply for private health insurance coverage. This may be feasible for people above a certain income level or for all citizens who do not wish to be insured by a sickness fund (e.g. in Switzerland). On the other hand, the political goal of risk-sharing and solidarity within the society is violated when only those with a high income opt out of the system.

The mutual structure of health funds makes it easier to meet the needs of different groups within the population. They are less bureaucratic than social security health insurance as they are more clearly arranged and better controlled by the members and their employers. Therefore their administrative costs are usually lower than the overhead costs of social security health insurance or private health insurers. Moreover it is possible to create competition between 
private health insurers. Moreover it is possible to create competition between the different funds, so the citizens can choose which fund best fits their individual needs and financial condition.

Nevertheless, health funds fail to insure people without formal employment. Although it is also possible to insure self-employed people and workers without formal employment, this is only feasibly with a risk examination of the applicant and risk-related premiums, as otherwise the danger of adverse selection would be to large.

Figure 7: Types of Managed Care Organizations

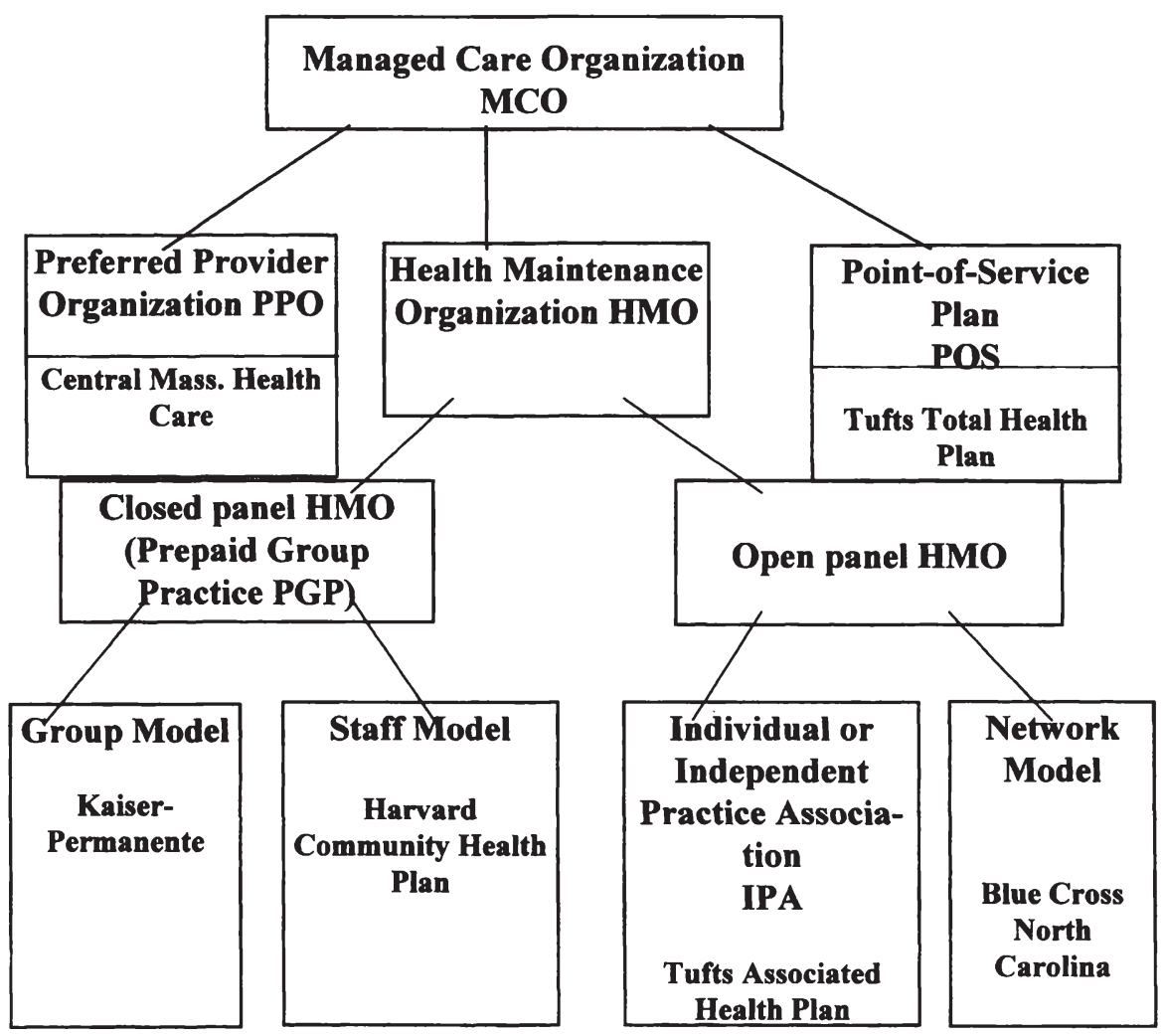

\subsection{Managed Care Systems}

Managed Care Systems are privately operated insurance programs run by business firms or by so-called Health Maintenance Organizations (HMOs). These schemes are pre-paid on the basis of annual capitation and provide comprehensive health care benefits for their members. In the USA nearly 50 
million citizens are insured in almost $700 \mathrm{HMOs}$ with a rising trend. The organization of such HMOs is various as shown in figure 7 , which does not present all existing organization forms for this type of health care financing. Examples of the various types of HMOs are also provided in this figure. These organizations should be contacted for further information on the special features of financing and benefit management.

A basic element of managed care is selective contracting, which means that a greater number of patients is promised to specific providers who agree to provide services under contract with a purchaser of these services (health plan or employer). The providers agree under these contracts to undergo utilization controls (e.g. a specific length of stay in hospital is allowed by the insurer, and any extension needs a special approval) and to accept a discounted price or fee schedule. This system, of course, means limited choice for the enrollees which might adversely affect patient satisfaction. Apart from the number of patients, which might encourage a provider to enter into contract with the HMO, other incentives are possible. For example, providers may receive a share of surpluses from the health insurance.

In preferred provider organizations (PPO) the health plan contracts with independent physicians, hospitals and other healthcare providers who become the "preferred" providers, accepting reimbursement on a negotiated fee schedule. Patients do not generally need authorization to obtain services from individual providers within the network. Although members obtain a greater level of coverage if they use the preferred providers, they may also receive treatment outside the network for a higher co-payment or deduction per visit or hospitalization.

A point-of-service (POS) plan provides a difference in benefits (e.g., $100 \%$ coverage rather than $70 \%$ ) depending on whether a member chooses to use the plan (including its providers and in compliance with the authorization system), or go outside the plan for services and pay a higher deduction or copayment. It is called "point-of-sale" because members choose how to receive services at the time they need them.

A closed panel HMO is a managed care plan that contracts with physicians on an exclusive basis for services and does not allow those physicians to see patients from another managed care organization; the term usually refers to staff and group model HMOs. A group model HMO contracts with a single medical group for the provision of healthcare services. The physicians are employed by the group practice, not the HMO, and the group practice typically has an exclusive contract with the HMO. In a staff model HMO physicians are salaried employees of the HMO. Medical services are delivered in HMO-owned health centers and, generally, only to HMO members. It is usual to pay the health service suppliers according to a DRG-system, but a fee-for-service system or capitation (an amount per enrollee) is also employed by some HMOs for 
specific services. These schemes are called "Managed care", because they negotiate with hospitals and doctors on prices, quality-of-care and the way in which patient careers are "managed". Competition is maintained both between the different HMOs (who compete on price, benefits and suppliers who are under contract or employed by the HMO) and between the different providers (who compete on price and quality of care). This basic system of HMOs is shown in figure 8:

\section{Figure 8: Group HMO}

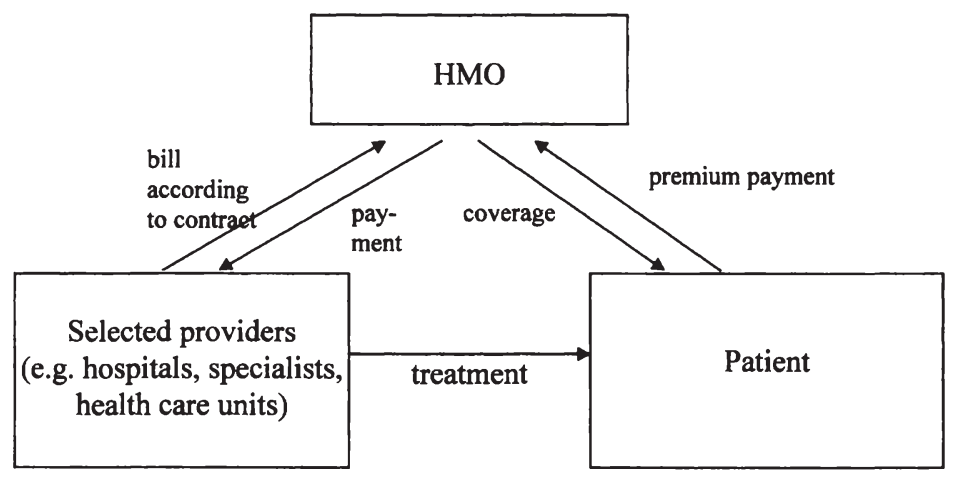

Open panel HMOs are managed care plans which contract with independent physicians to deliver care in their own offices. Physicians can see patients from numerous managed care organizations. The IPA (individual or independent practice association) model is an organized system of care in which an HMO contracts with independent, private-practice physicians or associations of such physicians, who see HMO members and other patients. Physicians are paid on a modified fee-for-service or capitated basis. In a network model the HMO contracts with multiple group practices and/or integrated organizations (a mixture of staff, group and IPA structures).

HMOs are priced on actuarial principles, i.e. premiums are not income-related but reflect the risk of illness of the insured. This is also true for group insurance (e.g. health insurance for all employees in a company), as premiums are experience-rated according to the health status and health expenditure of the particular company's employees. The higher the number of insured in a group insurance (given the same risk structure), the lower the premiums can be due to lower administrative costs and better interpersonal risk-sharing.

In managed care, purchasers of services (employers or insurers) directly manage the delivery of health services to a defined group of enrollees (e.g. diabetics, AIDS patients, hypertension patients). The system is characterized by competi- 
tion on different levels: providers compete to offer services, and consumers choose health plans based on which offers a given quality of care for the lowest price. In this way managed care systems can allocate resources in desirable directions compared to unmanaged fee-for-service systems. Unnecessary hospitalization in particular can be decreased, and costly treatment alternatives such as inappropriate specialist care can be replaced by increased use of primary care.

On the other hand in rural areas there is often the choice of only a few providers (if not only one, e.g. a district hospital) or just one network of providers. Furthermore, some consumers might not feel comfortable with this restricted choice of provider, as they may have established physician relations or need certain highly specialized services such as mental health, rehabilitation or treatment for particular diseases which is only offered by facilities of nationwide importance. The argument that (due to the large pressure on the provider to produce services cost-effectively) the quality of care would be lower in managed care facilities compared to other systems, could not be confirmed in comparative studies so far.

\section{Comparative analysis of different options}

The different options for health care financing presented above have advantages and disadvantages. An optimal solution always depends on the particular circumstances of the country, its economic, social and historical background and the political goals and will. It is, for example, impossible to introduce a system based on private health insurers alone, when the experience of such insurance is relatively limited and no potential providers of coverage exist. It is also difficult to introduce a tax-financed system, when the legal structure of the country fails to promote trust in governmental institutions due to wide spread corruption or large shadow economy.

Apart from these structural considerations for the choice for a particular financing system (or a mixture of various types), it is also important to discuss the priorities which should be met by the health care systems. If, for example, cost-containment takes first priority, a tax-financed scheme which offers a wide range of instruments for government intervention appears to be the best. However, such a system will have more administrative problems and lack quality of care. Moreover an operational, relatively efficient civil service is required, as otherwise resource allocation will be far from optimal.

If freedom of choice for patients / insured and providers is a major goal of the system, private health insurance should be considered, where the citizens can choose their health insurance and physicians on their own. Unfortunately these systems are not very adept at avoiding cost escalation and tent to offer many incentives to produce and consume as many health services as possible (at the insurer's expense). 
Statutory social health insurance does more to promote the idea of insurance than a tax-financed system which can lead to greater self-determination. On the other hand as this financing type is a monopoly, the anticipated administration costs are relatively high and the anticipated quality of the health providing system is relatively low. Another disadvantage of funds (public or private) as opposed to fiscal financing is the risk of under funding for preventative services, as the Ministry of Health has less direct influence the health service budget allocation. "This has been the experience of the Medicare program in the United States."

Mutual health funds has greater incentive than social security health insurance to contain costs (as they have no monopoly on the health financing market) and to provide appropriate care . Their performance is depends to a large extent on the internal process of managing the system, i.e. the democratic elections to appoint the board of the fund have to be accepted by the members, and the division of contributions between employees and employers must be negotiated without cheating either partner. The difficult question as to what is a fair share for an individual member to pay into the fund, is already resolved in a taxfinanced system, in which all public burdens are shared by a fixed tariff.

Managed care systems define themselves in a world of competition. If a market solution is not accepted as an appropriate allocation mechanism for the health care sector, this financing system should not be applied. On the other hand market instruments are most common in systems where people do not expect the government to be liable for every public concern. If for example the patients are used to paying user fees for health services, they are more likely to accept a prepayment to the provider (or a provider-based institution like a staff-based HMO) than people who already enjoy free health care.

There is no optimal system which meets the three goals equity, efficiency end effectiveness at the same time and in every segment of the health care system. Experience shows that particularly in less industrialized countries, the inefficiency of the government and other public bodies tends to increase, and that public funds are often not administered appropriately. Tax-financed and government-managed health services will not be a good solution to cover the population in developing countries and even industrialized countries. Highly industrialized countries like many EU-countries have made good experience with mandatory social health insurance and managed competition of health care plans. There is some doubt if these models would work in other countries. Every country has to make its own experience and has to make its own choice. 


\section{References}

FUCHS, Victor R. (1993)

The Future of Health Policy, Cambridge: Harvard University Press

VAN DE VEN, Wynand P.M.M. et al. (eds.) (November 1994)

Forming and Reforming the Market for Third-Party Purchasing of Health Care Social Science and Medicine, Special Issue, Volume 39, Number 10

RAFFEL, Marshall W. (ed.) (1997)

Health Care and Reform in Industrialized Countries, Pennsylvania, Pennsylvania State University Press

SCHWARTZ, Friedrich Wilhelm et al. (eds.) (1996)

Fixing Health Budgets, Chichester: John Wiley \& Sons 


\title{
Ongoing Reforms of Latin American Health Systems: \\ Can Market-Oriented Reforms \\ Help to Solve the Problems?
}

\author{
Klaus Liebig ${ }^{\star}$
}

\section{Introduction}

The public sector has traditionally played a dominant role in the delivery of health care in Latin America. Bureaucracies of the Ministries of Health or of public social security institutes have been responsible for providing preventive and curative care in the region. In many cases, the results have been impressive. However, only half of the resources have been channeled through the public sector, the rest has come from private sources. In recent years the participation of the private sector with regard to the purchase and delivery of health services has been increasing. Governments are considering or have already implemented "market-oriented reforms" in the sector.

The main reason for this development is the widespread concern over the efficiency and effectiveness of public health services in Latin America. Introducing competition and using private initiatives seems promising to improve the situation and fits perfectly into the overall economic reform program of most Latin American countries. But can market-oriented reforms really help to solve the problems of health care systems in Latin America? Or do they rather create different shortfalls?

To answer this question, it will be clarified first what the term „market-oriented reforms" can mean. Moreover, one has to understand the problems of health systems in different countries of the region. Sections 3 and 4 provide information on this. Later, the expected effects of market-oriented reforms will be analyzed theoretically and some evidence from earlier reforms in the region will be provided. Finally, the results will be confronted with the problems to see if the reforms can be effective.

It is important to note that not all aspects of health systems can be dealt with in a short paper like this. Thus, only the most important effects of market-oriented reforms in the provider and purchaser markets are discussed. All initiatives that try to make bureaucratic delivery systems more efficient (like e.g. reforms of the payment mechanism, decentralization etc.) are not within the scope of this

\footnotetext{
- Deutsches Institut für Entwicklungspolitik (DIE), Tulpenfeld 4, 53113 Bonn.
} 
paper, although they might be very useful. Moreover, the market for pharmaceuticals remains untreated as well.

\section{Characteristics of "market-oriented reforms“ in health systems}

„In many (predominantly) publicly financed health care systems market-oriented health care reforms are being implemented or have been proposed. The purpose of these reforms is to make resource allocation in health care more efficient, more innovative and more responsive to consumers' preferences while maintaining equity. “l This quote, referring to reforms of health care systems in the OECD-countries, holds as well for the ongoing reforms in Latin American health care systems. The term „market-oriented reforms" means that competition is introduced to formerly bureaucratic systems and that consumers have freedom to choose.

To be more specific on the nature of reforms, it is necessary to recall the functioning of health care markets very briefly. One can distinguish four types of actors:

- Patients or the consumers of medical care

- Medical staff or the suppliers of medical care

- Purchasers of care (the ,third-party payer“)

- The State as regulating agency

It is neither necessary that all types of actors are present (e.g. in the traditional medicine sectors of developing countries the state hardly performs any regulating activities and there are no third-party purchasers), nor that one type of actor is different from another (e.g.: the state can perform the roles of the regulator, third-party purchaser and provider at the same time).

It is important to note that market-oriented reforms never question the state's regulating function. On the contrary, it is widely acknowledged that a competitive health care system requires more regulation than a monopolistic one. Market-oriented reforms can introduce competitive pressures between two types of agents: one common aspect is to encourage competition among health care providers. Consumers then may freely choose between alternative providers to induce providers to act in their interests. The other possibility, much more controversial, is to foster competition between third-party payers. The efficiency-enhancing effect arises here by consumers choosing the insurer that provides them with the best package of medical care. Thus, insurers are responsible to look for the most efficient providers on behalf of their clients.

1 van de Ven $(1996,655)$. 
This distinction between two dimensions of competition in health care markets yields four possible models for a health care system: ${ }^{1}$

Figure 1: Four basic models of health care markets with third-party payers ('insurers') and providers of care

\begin{tabular}{|l|l|c|c|}
\cline { 3 - 4 } \multicolumn{2}{c|}{} & \multicolumn{2}{c|}{ providers of care } \\
\cline { 3 - 4 } \multicolumn{2}{c|}{} & $\begin{array}{l}\text { price } \\
\text { competition }\end{array}$ & $\begin{array}{l}\text { no price } \\
\text { competition }\end{array}$ \\
\hline $\begin{array}{l}\text { Third-party } \\
\text { payers }\end{array}$ & price competition & 1 & 3 \\
\cline { 2 - 4 } & no price competition & 2 & 4 \\
\hline
\end{tabular}

As the third-party payer plays such an important role in virtually all health systems around the world, it is worthwhile to explain his functions. Health care is a good with some special characteristics that distinguish it from common goods. ${ }^{2}$ Due to these characteristics one cannot expect a free market in health care to deliver an optimal result for a society. The third-party payer can help to improve the outcome for societies by fulfilling the following three functions: ${ }^{3}$

The insurance function: By taking over consumers' financial risk of health care utilization, the third-party assures an optimal allocation of risk in societies.

The agency function: The third-party helps to overcome the problems associated with information asymmetries. It tries to reduce moral hazard, should provide information about the quality of care and behave as a prudent buyer of care on behalf of the consumer.

The access function: Third-parties can guarantee universal access to basic health services, thus loosening the tie between ability to pay and the received amount of care, which would be typical for a market of common goods.

While the insurance function is typical for all markets that involve risk and the access function depends heavily on the preferences of societies regarding equity in health care markets, the agency function is crucial for achieving efficiency in the health system. It is an empirically open question if competing third-party payers or a public monopsonistic one perform better with regard to all three functions. It is obvious, however, that both alternatives can only perform well on the agency function if insurers stay in contact with providers. This is not the case if insurers simply reimburse their clients for outlays of medical services. Thus there is a trend in all countries towards using contracts or even integrating

van de Ven et.al. (1994, 1408).

2 Among other points, the following characteristics can be mentioned: asymmetric information, external effects, incomplete knowledge, equity considerations.

3 See van de Ven et.al. (1994, 1405-1406). 
the financing and delivery institutions (both models can be called types of „managed care" ${ }^{\text {"l }}$ ). One of the most important elements of these contracts are the provider-payment mechanisms. ${ }^{2}$ Third-party payers are then transformed into third-party purchasers of care. In what follows we look on the effects of marketoriented reforms on the provider side as well as on the third-party purchaser side.

\section{Challenges for Latin American health systems}

After more than a decade of economic reforms, Latin American countries have changed their institutional settings towards market-economies. The reforms of the health care systems may be called "latecomers" in this reform process, as they have been initialized only recently in most countries. On the other hand, in many countries there has been a constant flow of piecemeal reforms without a clear concept.

Most health systems in Latin America consist of three subsystems. These are usually associated with different population groups and certain mechanisms of operation. ${ }^{3}$ While the state with its Ministry of Health mainly serves the poor via bureaucratic public delivery systems, the social security institutions serve employees of the formal sector. Social insurance is organized along the Bismarckian principles with mandatory payroll taxes. In most countries the private sector plays an important role in the delivery of medical services. Although the rich provide the bulk of the revenues for this sector, it is important to recognize that the poor frequently have to rely on the private sector if the state does not provide adequate coverage (for more on this see 4.2). Table 1 shows the main characteristics of the four health subsystems in Latin America:

Although the countries of the region differ markedly with respect to health spending, health indicators and health systems, analysts agree that Latin American health care systems face the following problems: ${ }^{4}$

Health outcomes are comparatively poor. Compared to their health expenditure one would expect a better performance of health indicators like child mortality and life expectancy. This phenomenon has been dubbed "health gap" by the IDB.

Allocative and technical inefficiency is low in the health care systems, i.e. resources are biased towards less cost-effective interventions and they are wasted because of suboptimal input-combinations.

\footnotetext{
See Enthoven (1997).

On this, see Maceira (1998).

See IDB (1996, 305-306).

4 See e.g. IDB (1996), Medici et.al. (1997) and Titelman; Uthoff (1999).
} 
Table 1: The four main health service delivery systems in Latin America and the Caribbean

\begin{tabular}{|c|c|c|c|c|c|c|c|}
\hline System & $\begin{array}{l}\text { Regula- } \\
\text { tion }\end{array}$ & $\begin{array}{l}\text { Sources of } \\
\text { financing }\end{array}$ & $\begin{array}{l}\text { Cost } \\
\text { controls }\end{array}$ & $\begin{array}{l}\text { Provider } \\
\text { payment } \\
\text { mecha- } \\
\text { nism }\end{array}$ & $\begin{array}{l}\text { Con- } \\
\text { sumer } \\
\text { options }\end{array}$ & $\begin{array}{l}\text { Owner- } \\
\text { ship }\end{array}$ & $\begin{array}{l}\text { Criteria } \\
\text { for } \\
\text { coverage }\end{array}$ \\
\hline $\begin{array}{l}\text { Private out- } \\
\text { of-pocket } \\
\text { spending }\end{array}$ & Minimal & $\begin{array}{l}\text { Out-of- } \\
\text { pocket }\end{array}$ & None & $\begin{array}{l}\text { Fee for } \\
\text { service }\end{array}$ & Many & Private & $\begin{array}{l}\text { Ability to } \\
\text { pay }\end{array}$ \\
\hline $\begin{array}{l}\text { Private } \\
\text { insurance } \\
\text { (a) }\end{array}$ & $\begin{array}{l}\text { Some } \\
\text { financial } \\
\text { regula- } \\
\text { tion }\end{array}$ & $\begin{array}{l}\text { Employers } \\
\text { and house- } \\
\text { holds }\end{array}$ & $\begin{array}{l}\text { Range of } \\
\text { cost con- } \\
\text { trols }\end{array}$ & $\begin{array}{l}\text { Range of } \\
\text { payment } \\
\text { mecha- } \\
\text { nisms }\end{array}$ & Many & Private & $\begin{array}{l}\text { Ability to } \\
\text { pay }\end{array}$ \\
\hline $\begin{array}{l}\text { Social in- } \\
\text { surance (a) }\end{array}$ & $\begin{array}{l}\text { Little or } \\
\text { no ex- } \\
\text { ternal } \\
\text { regula- } \\
\text { tion }\end{array}$ & $\begin{array}{l}\text { Mandated } \\
\text { payroll } \\
\text { taxes }\end{array}$ & $\begin{array}{l}\text { Range of } \\
\text { cost con- } \\
\text { trols }\end{array}$ & $\begin{array}{l}\text { Range of } \\
\text { payment } \\
\text { mecha- } \\
\text { nisms }\end{array}$ & Limited & $\begin{array}{l}\text { Collec- } \\
\text { tive }\end{array}$ & $\begin{array}{l}\text { Mandated } \\
\text { contribu- } \\
\text { tions }\end{array}$ \\
\hline $\begin{array}{l}\text { Public } \\
\text { services } \\
\text { financed by } \\
\text { general tax } \\
\text { revenue }\end{array}$ & $\begin{array}{l}\text { No ex- } \\
\text { ternal } \\
\text { regula- } \\
\text { tion }\end{array}$ & $\begin{array}{l}\text { General tax } \\
\text { revenue }\end{array}$ & $\begin{array}{l}\text { Public } \\
\text { budgets }\end{array}$ & $\begin{array}{l}\text { Installed } \\
\text { capacity }\end{array}$ & $\begin{array}{l}\text { Re- } \\
\text { stricted }\end{array}$ & Public & $\begin{array}{l}\text { Universal, } \\
\text { but espe- } \\
\text { cially as a } \\
\text { last resort } \\
\text { for the } \\
\text { poor }\end{array}$ \\
\hline
\end{tabular}

(a) Can include managed care.

Source: Medici et.al. $(1997,216)$.

Access to the health system is unequal and highly stratified. The quality of government provided health care is often poor. Large parts of the population are not adequately covered.

Expenditure levels tend to rise and have lead to financial imbalances in some countries. The need to pursue tight fiscal policies implies that cost containment is an important goal for the health care systems. ${ }^{1}$

Health Care systems suffer from weak coordination, duplication of services and not-intended interdependencies between the health subsystems. An overall framework is frequently missing and the system works without proper regulation.

Public health care systems do not enjoy public support. Many clients are not satisfied with the services offered and try to opt out of the public system.

The challenges that health reforms in the region have to match may be summarized as follows: Reforms should ensure universal and equitable access to

1 In theoretical terms, this point touches another dimension of efficiency, namely that overall the optimal amount of resources is spent for the health sector. However, this efficiency goal is difficult to operationalize and will not be treated specifically in this paper. 
good-quality health services at a sustainable price for the society. Allocative and technical efficiency are necessary (though not sufficient) conditions to meet these goals.

\section{Decomposing the general picture: Latin American health systems and the present role of the private sector}

\subsection{A simple typology of systems and problems}

To go beyond general prescriptions for Latin America, it is necessary to get an idea of the diversity of health systems and their corresponding problems. Table 2 lists some indicators for health expenditure and health outcomes in 25 Latin American and Caribbean countries.

It can be observed that important differences between the countries of the region exist: Per capita health expenditures range from 49 PPP \$ in Haiti to 977 PPP \$ in Uruguay. While the public sector in Costa Rica devotes $6.3 \%$ of its GDP to health, in Guatemala it is only $1.7 \%$. Similar differences can be detected by a look at the indicators for the health status of the population: life expectancy is more than 20 years lower in Haiti than in Costa Rica, infant mortality rates are nearly 7 times as high in Haiti and Bolivia as in Costa Rica and Chile, while the ratio of adult mortality rates is $4: 1$.

The IDB has categorized the health systems of the region according to "the relative importance of different subsystems, their particular internal forms of organization, and the relationships among them". ${ }^{1}$ They propose to distinguish four subregions (see map in the Annex). The largest subsystem consists of segmented systems, which means that the above mentioned health subsystems are all working in one country in a mainly uncoordinated manner. This is the largest subregion, including all of Central America (with the exception of Costa Rica), Haiti, the Dominican Republic, Suriname, Guyana, the Andean countries (apart from Colombia since the reforms in 1993), and Paraguay.

Integrated public systems are those with predominantly public systems. The English speaking Caribbean and Costa Rica fall into this category, relying on the ideas of Beveridge rather than Bismarck. ${ }^{2}$ A special case is Brazil, whose system has been called subcontracting system. The special feature of this system is that the unified public financing institution subcontracts private providers of medical services.

$\operatorname{IDB}(1996,308)$.

2 Although in Costa Rica the formal employed belong to the social insurance, the Ministry of Health mandated the social security institute to deliver medical services to the poor as well (and pays subsidies out of the public budget to make this financially viable). Both services are very well integrated so that it is possible to speak of an integrated system. 
Table 2: Health expenditures and health outcomes in Latin American countries

\begin{tabular}{|c|c|c|c|c|c|c|c|}
\hline Country & $\begin{array}{c}\text { GDP per } \\
\text { Capita } \\
\text { (in 1994 } \\
\text { PPP \$) }\end{array}$ & $\begin{array}{c}\text { Total } \\
\text { Health } \\
\text { Expendi- } \\
\text { ture per } \\
\text { Capita } \\
\text { (in 1994 } \\
\text { PPP \$) }\end{array}$ & $\begin{array}{c}\text { Total } \\
\text { Health } \\
\text { Expendi- } \\
\text { ture } \\
\text { (in \% of } \\
1994 \text { GDP) }\end{array}$ & $\begin{array}{c}\text { Public } \\
\text { Sector } \\
\text { Health } \\
\text { Expendi- } \\
\text { ture } \\
\text { (in \% of } \\
1994 \text { GDP) }\end{array}$ & $\begin{array}{c}\text { Child } \\
\text { Mortality } \\
\text { Rate } \\
\text { (Infants per } \\
\text { 1,000 live } \\
\text { births, } \\
1995 \text { ) }\end{array}$ & $\begin{array}{c}\text { Life ex- } \\
\text { pectancy } \\
\text { at birth } \\
\text { (years, } \\
\text { 1995) }\end{array}$ & $\begin{array}{c}\text { Adult Mor- } \\
\text { tality } \\
\text { (Probability of } \\
\text { dying between } \\
\text { ages } 15 \text { and } 60 \\
\text { (times } 1,000 \text { ), } \\
1995 \text { ) }\end{array}$ \\
\hline ARG & 9575 & 931 & 9,7 & 4,3 & 22 & 72,5 & 130 \\
\hline BAH & 10847 & 460 & 4,2 & 2,5 & 15 & 73,5 & 119 \\
\hline BAR & 10224 & 700 & 6,8 & 4,4 & 13 & 75,5 & 101 \\
\hline BEL & 4196 & 338 & 8,0 & 6,0 & 37 & 74,5 & 147 \\
\hline BOL & 2733 & 194 & 7,1 & 4,1 & 70 & 60,5 & 264 \\
\hline BRA & 5730 & 264 & 4,6 & 1,8 & 45 & 67,0 & 152 \\
\hline $\mathrm{CHI}$ & 9907 & 613 & 6,2 & 2,5 & 12 & 75,0 & 119 \\
\hline COL & 6492 & 477 & 7,4 & 2,9 & 26 & 70,0 & 166 \\
\hline $\mathrm{CR}$ & 6374 & 544 & 8,5 & 6,3 & 13 & 76,5 & 92 \\
\hline DR & 3991 & 227 & 5,7 & 1,8 & 38 & 70,0 & 128 \\
\hline $\mathrm{ECU}$ & 4908 & 259 & 5,3 & 2,0 & 37 & 69,5 & 145 \\
\hline ELS & 2620 & 153 & 5,9 & 2,4 & 37 & 68,5 & 192 \\
\hline GUA & 3405 & 111 & 3,2 & 1,7 & 45 & 65,5 & 206 \\
\hline GUY & 2370 & 123 & 5,2 & 4,3 & 61 & 63,5 & 200 \\
\hline HAI & 1607 & 49 & 3,6 & 1,3 & 73 & 55,5 & 360 \\
\hline HON & 2027 & 113 & 5,6 & 2,8 & 46 & 66,5 & 138 \\
\hline JAM & 3612 & 176 & 4,9 & 2,5 & 13 & 74,0 & 117 \\
\hline MEX & 7370 & 311 & 4,2 & 2,4 & 33 & 71,5 & 125 \\
\hline NIC & 2016 & 174 & 8,6 & 5,3 & 47 & 67,5 & 153 \\
\hline PAN & 6860 & 457 & 6,7 & 4,7 & 23 & 73,5 & 113 \\
\hline PAR & 3375 & 173 & 5,1 & 1,8 & 41 & 69,0 & 133 \\
\hline PER & 4181 & 156 & 3,7 & 2,2 & 48 & 66,5 & 184 \\
\hline SUR & 2246 & 90 & 4,0 & 2,0 & 34 & 69,5 & 155 \\
\hline TAT & 6167 & 211 & 3,4 & 2,1 & 14 & 72,5 & 150 \\
\hline URU & 7269 & 977 & 13,4 & 7,0 & 18 & 73,5 & 129 \\
\hline VEN & 8199 & 617 & 7,5 & 3,0 & 23 & 72,0 & 133 \\
\hline
\end{tabular}

Source: Bos et.al. (1999). 
Finally, there are three countries in the Southern Cone (Chile, Argentina and Uruguay) where social security institutions play an important role. These countries have been the first within the region to introduce social security along Bismarckian lines. Together with Colombia (after the 1993 reform) theses 4 countries are characterized by an important participation of different thirdparty payers (public and private) which use a quite sophisticated net of contracts between them and providers. They can therefore be called contract-intensive systems.

In the following table the same information as in table 2 is given, but this time countries are grouped in the four health subregions. ${ }^{1}$ Additionally, we have distinguished low and middle income countries within the segmented systems since differences in terms of economic development between those two subgroups are very large. Some interesting observations can be made: Countries with integrated public systems show the best health indicators, which is especially surprising in comparison to the middle income countries with segmented systems and with the Southern Cone countries, as these countries have higher per capita GDPs and higher per capita health expenditures. Brazil's health indicators are comparable to the low income countries with segmented systems although it devotes nearly double health expenditures per capita. The Southern Cone Countries have good health indicators, but spend by far the most resources on health care (as a share of GDP as well as on a per capita base).

It has been shown frequently that the level of economic development exercises the greatest influence on health indicators. In Figure 2 it can be observed how different health systems influence health outcomes (here: life expectancy) independently of GDP (as a proxy for economic development). The figure reinforces the conclusions drawn above: ${ }^{2}$ The English speaking Caribbean and Costa Rica gain a lot in terms of life expectancy at a quite reasonable price. Southern Cone countries spend much more but reach life expectancy numbers that would be expected with regard to their level of economic development. Brazil and the countries with segmented health systems reach a life expectancy which is lower than expected. Thus the term "health gap" refers to these countries rather than to Latin America as a whole. The figure suggests strongly that the efficiency of resource use in the different health systems varies.

1 Although Colombia today falls in the group of the contract-intensive systems, it appears here still under the heading of middle-income segmented systems. This is due to the fact that the data used is from the year 1994, i.e. before the reforms could have had a significant impact on the indicators shown above.

2 Note, however, that there are slight differences as well. This is due to the fact that the IDB used older data than the calculations on which the tables above are built. The difference in the case of Brazil is particularly striking, as the newer data indicate much lower health expenditures as a percentage of GDP than did the IDB data (4.6\% instead of $7.1 \%)$. It remains to be confirmed which data is more reliable. 
Table 3: Health expenditures and health outcomes in the four health subregions

Types of Health Systems.

\begin{tabular}{|c|c|c|c|c|c|c|}
\hline Variable & $\begin{array}{c}\text { Segmented } \\
\text { (low } \\
\text { income) }\end{array}$ & $\begin{array}{l}\text { Segmented } \\
\text { (middle } \\
\text { income) }\end{array}$ & $\begin{array}{l}\text { Inte- } \\
\text { grated } \\
\text { Public }\end{array}$ & $\begin{array}{c}\text { Sub- } \\
\text { contracting } \\
\text { (Brazil) }\end{array}$ & $\begin{array}{l}\text { Contract } \\
\text { Intensive }\end{array}$ & $\begin{array}{c}\text { All } \\
\text { Countries }\end{array}$ \\
\hline $\begin{array}{l}\text { Mean - GDP per } \\
\text { Capita } \\
\text { (in 1994 PPP \$) }\end{array}$ & 2957 & 7230 & 6903 & 5730 & 8917 & 5319 \\
\hline $\begin{array}{l}\text { Mean - Total Health } \\
\text { Exp. per Capita } \\
\text { (in 1994 PPP \$) }\end{array}$ & 152 & 466 & 405 & 264 & 840 & 342 \\
\hline $\begin{array}{l}\text { Mean - Total Health } \\
\text { Expenditure } \\
\text { (in \% of } 1994 \text { GDP) }\end{array}$ & 5,25 & 6,45 & 5,97 & 4,60 & 9,77 & 6,10 \\
\hline $\begin{array}{l}\text { Mean - Public Sector } \\
\text { Health Exp. } \\
\text { (in \% of } 1994 \text { GDP) }\end{array}$ & 2,64 & 3,25 & 3,97 & 1,80 & 4,60 & 3,23 \\
\hline $\begin{array}{l}\text { Mean - Child } \\
\text { Mortality Rate } \\
\text { (Infants per 1,000 } \\
\text { live births, 1995) }\end{array}$ & 48,1 & 26,3 & 17,5 & 45,0 & 17,3 & 34,0 \\
\hline $\begin{array}{l}\text { Mean - Life } \\
\text { expectancy at birth } \\
\text { (years, 1995) }\end{array}$ & 66,0 & 71,8 & 74,4 & 67,0 & 73,7 & 69,8 \\
\hline $\begin{array}{l}\text { Mean - Adult } \\
\text { Mortality } \\
\text { (Probability of dying } \\
\text { between ages } \\
15 \text { and } 60 \text { (times } \\
1,000), 1995 \text { ) }\end{array}$ & 188,2 & 134,3 & 121,0 & 152,0 & $\cdot 126,0$ & 155,8 \\
\hline Number of countries & 12 & 4 & 6 & 1 & 3 & 26 \\
\hline
\end{tabular}

Source: Bos et.al. (1999).

Problems and achievements of the health subregions may be summarized as follows: In segmented systems health expenditure is still quite low, maybe too low to reach acceptable health outcomes. However, at the same time the health gap suggests that important allocative and technical inefficiencies exist. Low coverage rates and highly stratified subsystems do not guarantee an equitable access especially of the poor population to health services. Brazil faces similar problems. "The combination of underfunding public health care provision, faulty payment mechanisms, and weak regulatory structures has engendered problems of coverage and quality, along with high unit costs for the services that 
Figure 2: Expenditures and health gaps in four subregions

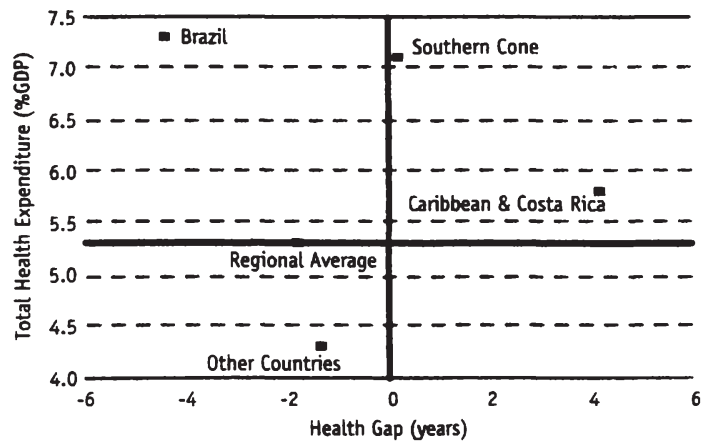

Note: The health gap compares observed life expectancy to the expectation based on per capita income.

Source: IDB (1996, 303).

are actually provided." "I Integrated public systems display the best health outcomes.

However, these countries have to be aware of high and rising costs which have reached dangerous levels. Moreover they face some of the typical problems associated with bureaucratic delivery systems such as inflexible input allocation (which will become even more important when the epidemiological transition goes on and resources need to be reallocated to meet the changing needs). Nevertheless, allocative and technical efficiency seems to be high in comparison to the rest of the region. Finally, contract-intensive systems suffer from high and partly unsustainable expenditure levels combined with mixed experience regarding efficiency. The interplay of health subsystems in these countries frequently generates perverse incentives for providers thus increasing costs and lowering service quality in the public sector. Access in Southern Cone countries is still stratified, although coverage levels as a whole are comparable to the ones in public integrated systems. ${ }^{2}$ Additionally, the high percentage of persons covered by social or private insurance yields problems due to missing or wrong regulation.

IDB $(1996,317)$.

2 Coverage in Colombia is still much lower than in the Southern Cone, but it is claimed that the 1993 reforms helped to increase coverage considerably. 


\subsection{The present role of the private sector in Latin American health systems}

Although market-oriented reforms need not necessarily involve privatization, in fact both phenomena frequently go in tandem. Thus, a short look on the present role of the private sector is necessary before turning to the reforms as such. In Latin America, private spending on health care is comparatively high. Recent studies have shown that the private sector is spending more or less the same amount as the public sector. This share is among the highest in the world. ${ }^{1}$ Basically private spending for health care is channeled to providers via three ways: Out-of-pocket payments for medical treatment and medicines is the conventional way of financing health care. It is the principal form of financing in the sector of traditional medicine. Moreover, they are used in the modern health care sector by those who are not adequately covered by insurance mechanisms - either because the state does not provide coverage (especially relevant for the poor) or because individuals deliberately decide not to buy insurance (relevant for the rich if insurance markets are not working well). Premiums for private insurers are increasing in importance. The insurers then perform their role as third party purchaser of care and pay the providers either by reimbursing the outlays of the patients or by compensating the providers (via different formulas). Finally, private copayments are extensively used by social and private insurers to counter moral hazard and to raise additional resources for the health sector.

Private providers of medical care are common in all countries of the region. However, this refers mainly to doctors working in their practices, while hospitals primarily belong to the public Ministries of Health or to the public Social Security institutions. An exception is Brazil where about $75 \%$ of the hospital beds are in private hospitals. ${ }^{2}$ In the poorer countries, involvement of not-for-profit providers (NGOs) is considerable. At the same time, in these countries traditional medicine still has its strongest appearance (namely in Bolivia, Guatemala, Haiti and Paraguay). ${ }^{3}$

Private health insurance, on the other hand, is still a quite new phenomenon. Today, only in the Southern Cone countries more than $15 \%$ of the population is covered by private health insurance. Numbers are, however, rising in some countries, notably in Brazil, Colombia, and the Dominican Republic, while a similar development is expected to take place soon in countries like Mexico, Venezuela and Peru. ${ }^{4}$

\footnotetext{
See IDB $(1996,248)$.

See Katz; Miranda $(1994,15)$.

See IDB (1996, 313).

4 For the development of private insurers using different managed care models see Stocker et.al. (1999).
} 


\section{Factors that frame possible health system reforms in Latin America}

\subsection{Socio-economic conditions}

Although Latin America recovered in the 90s from the economic breakdown of the „lost decade“, the economies are still vulnerable. Governments have to maintain tight fiscal policies and some structural reforms of the labor regime, of social policies and of different branches of economic policy remain to be implemented. At the same time, despite some progress poverty levels remain high. The distribution of income, land and wealth remains extremely unequal compared to the rest of the world. Urban informal sector employment is high and has even been growing in the last years (ranging from around $67 \%$ in Paraguay to $38 \%$ in Uruguay). ${ }^{1}$ Although urbanization rates are comparatively high in the developing country context, still most of the poor live in rural areas.

Table 4 summarizes some socio-economic indicators for Latin American countries. One can draw the following conclusions out of these data with respect to health care reforms: Public resources for the health sector are limited. Ability to pay for health services of large parts of the population is low, while, due to high inequality, there are some people very well-endowed to pay for high quality care. If it is the goal to guarantee universal access to a basic package of health care, on the one hand significant redistribution (subsidies) is necessary. Financing health care via mandated payroll taxes alone will not be sufficient due to high informal employment. Thus, a significant part of health care expenditures has to be financed out of general taxes. On the other hand, it will hardly be feasible to guarantee equal access to all possible health services in a very unequal society. Hence, reforms have to provide a framework for people who want (and are able) to buy more care than the basic package.

On the expenditure side, to reach the poor health care provision has to be improved especially in rural areas.

\subsection{Political and institutional conditions}

Market-oriented reforms fit well in the overall ideological shift in favor of market solutions in Latin America. However, there are some reasons why health care reforms are particularly difficult even for governments that have the political will to do so:

The health care sector is traditionally a sector where stronger egalitarian values persist than in the rest of the economy. ${ }^{2}$ It has been shown above that the public delivery systems show deficits in their effort to provide equitable health care. Market-oriented reforms will be popular if (and only if) they promise to improve

1 See Lora; Olivera (1998) for more on employment problems in Latin America.

2 Tobin (1970) called this phenomenon „specific egalitarianism“. 
Table 4: Socio-economic indicators for Latin American countries

\begin{tabular}{|c|c|c|c|c|c|}
\hline Country & $\begin{array}{c}\text { Urban } \\
\text { population } \\
\text { (\%) } 1995 \text { (a) }\end{array}$ & $\begin{array}{c}\text { Population } \\
\text { below the } \\
\text { poverty line (\%) } \\
\text { (b) }\end{array}$ & $\begin{array}{l}\text { Survey } \\
\text { year (b) }\end{array}$ & $\begin{array}{l}\text { Gini coefficient } \\
\text { (latest available } \\
\text { 1990-95) (a) }\end{array}$ & $\begin{array}{c}\text { Urban } \\
\text { informal } \\
\text { employment } \\
\text { (\%) } 1996 \text { (c) }\end{array}$ \\
\hline ARG & 88 & 25.5 & (1991) & & 53 \\
\hline BOL & 58 & & & 42 & 63 \\
\hline BRA & 78 & 17.4 & (1990) & 63 & 59 \\
\hline $\mathrm{CHI}$ & 86 & 20.5 & (1994) & 57 & 51 \\
\hline $\mathrm{COL}$ & 73 & 17.7 & (1992) & 51 & 57.5 \\
\hline CR & 50 & & & 46 & 47 \\
\hline DR & 65 & 20.6 & (1992) & 51 & \\
\hline ECU & 58 & 35.0 & (1994) & 47 & 53 \\
\hline ELS & 45 & 48.3 & (1992) & & \\
\hline GUA & 42 & & & 60 & \\
\hline HAI & 32 & 65.0 & (1987) & & \\
\hline HON & 48 & 50.0 & (1992) & 53 & 56.5 \\
\hline MEX & 75 & 10.1 & (1988) & 50 & 60 \\
\hline NIC & 63 & 50.3 & (1993) & 50 & \\
\hline PAN & 55 & & & 57 & \\
\hline PAR & 53 & 21.8 & (1991) & & 67 \\
\hline PER & 72 & 54.0 & (1986) & 45 & 58 \\
\hline TAT & 67 & 21.0 & (1992) & & \\
\hline URU & 90 & 31.3 & (1989) & 54 & 38 \\
\hline VEN & 93 & 31.3 & (1989) & 54 & 47.5 \\
\hline
\end{tabular}

Sources: (a) Bos et.al. (1999); (b) World Bank (1998); (c) Lora; Olivera (1998).

the record of the health system in terms of equity. It is not easy to create a perception in that direction since competition usually goes along with efficiency and differentiation, but not with equity. However, existing deficits show ample scope for improvements.

Vested interests of different stakeholders in the health care sector are very strong. Doctors, health staff and private insurers are frequently well organized, sometimes in the form of a cartel. Since every reform creates winners and losers and since the "target-group" of health reforms (the patients) does not have a 
strong organized voice in the political process, politicians face difficulties in promoting health reforms that involve structural changes.

In many countries of the region, public confidence in governments is low out of different reasons (perception of corruption, historical reasons like civil wars etc.). Moreover, it is frequently difficult to create a social consent with regard to a reform project as distrust between different groups and parties is large. All this leads to weak governments in terms of reform capacity in a sector where strong interests and moral values are intertwined.

Especially governments in the lower income countries of the region possess only limited capacities to organize the health sector. Some of the problems that have been described above can be traced back to this reason. Health reforms have to take this into account and should make the health sector easier to manage.

In sum, it can be observed world-wide that path dependency in the health sector is very strong. This conclusion holds even more for Latin America where societies are comparatively more fragmented and governments are weaker. Health care reforms are, however, not impossible. But if a democratic government wants to implement them, ${ }^{1}$ it will have to design complementary reforms to build stronger public support for the health reform. Most importantly, tax systems need to be improved to ensure a sufficient financial base of a health system that wants to ensure equitable access. Moreover, a government has to take into account that a reform always changes the options for further reforms in the future since new economic agents (e.g. by allowing private insurers to work) will later form an pressure group with certain interests to defend. In this sense, an institutional lock-in effect occurs due to the political economy of health reforms. Hence, structural reforms have to be designed very carefully. The new system has to be consistent, simple to administer and easy to understand for the general public.

\section{Results of market-oriented reforms in theory and Latin American practice}

\subsection{Competition among providers of medical care}

A wide range of options for market approaches on the provider side is possible: ${ }^{2}$ Comprehensive provider markets with private and public facilities competing for patients; auctions of concessions of primary health centers or hospitals; management contracts for the private sector to run public facilities; and contracting out of non-clinical hospital services (e.g. catering or cleaning).

1 Which was not the case, of course, with regard to the most radical health reform which took place in Chile in 1980 under the dictatorship of General Pinochet.

2 See Mills (1997, 262-263). 
It is useful to distinguish between rural and urban areas. In rural areas, there is frequently no consumer choice as geographical access to health facilities is limited. Introducing competitive pressures could be possible by fostering competitive bidding of private providers to run rural health posts. However, the design of the contract between purchasers and providers and - in many countries - the amount of resources the public budget devotes to underserved rural areas will be more important for the success of health reforms than a simple switch from public to private providers. The experience of the Mexican Rural Solidarity Program gives two insights: It is possible to extend coverage to a rural, dispersed population at a reasonable price, but strong commitment in budgetary terms and indicative planning of cost-effective measures is required. ${ }^{1}$

In urban areas, competition is already taking place between different providers. As we have seen, there is a range of providers of health services: Private doctors and clinics, public primary health centers and hospitals, and not-for-profit providers deliver medical treatment out of diverse motivations. They frequently face different incentives because of the different contracts with purchasers (especially with regard to the payment mechanism). Moreover, some doctors work in their private practice and in public facilities.

The effects of competition in the provider market depend on the incentives that doctors and hospitals face. If the third-party purchaser (regardless if public or private) reimburses full costs and does not employ strong monitoring, providers will tend to overserve clients. Brazil is an example for that behavior. Moral hazard on the supply and on the demand side combined with supplier-induced demand due to asymmetrical information lead to cost escalation and to allocative inefficiencies (as resources are not spent for the most cost-effective interventions). This trend is enforced if market-entry of suppliers is not regulated, as the experience, e.g. in Argentina, has shown that doctors try to increase the demand for medical services by focusing on product-differentiation (employing leading-edge technology and specialized services). Resources are thus further diverted from cost-effective treatments. ${ }^{2}$

On the other hand, if doctors receive capitated payments they have an incentive to employ the most effective treatments. However, the danger is that incentives work in the direction of underserving clients or of lowering quality. Costa Rica has experimented with capitation with some success. However, evidence is still inconclusive. $^{3}$

I See Mesa-Lago (1994, 101-106) for a description of the Solidarity program with its achievements and problems.

2 See Katz; Miranda (1994, 12). Argentina and Uruguay display indices of doctors per inhabitants that are higher than the OECD-average (3.3 per thousand compared to 2.3 per thousand). Moreover, specialists are concentrated in Montevideo and Buenos Aires where rates of one doctor per 200 (120) persons are reached. See Katz; Miranda (1994; 9).

3 See Mesa-Lago $(1994 ; 100)$ and Medici et.al. $(1997 ; 224)$. 
In the hospital sector anecdotal evidence suggests that the problem of technical inefficiency is particularly pressing. It is expected that competition among hospitals induces them to increase efficiency by combining inputs more rationally (e.g. the ratio of nurses and doctors), by improving internal organization, by shortening the average length of stay and by allocating resources in the areas where greatest medical need is observed. Moreover, dynamic efficiency gains might be realized if competition leads to innovative forms of clinical services, e.g. by fostering the development of ambulant procedures for certain treatments. All this can increase consumer satisfaction and improve the health status of the population since fewer resources are wasted.

However, one has to bear in mind the special conditions that are in place in Latin America. Competition requires decentralization of discretionary powers towards hospital managers, which has proven to be difficult mainly because of political pressures and shortages of human capital at the local level. Ministries of Health have been especially hesitant in giving local managers the power to decide about the employment of medical staff. As health care is a laborintensive sector, the labor regime is decisive for efficiency-improving reforms.

Finally, the uncoordinated existence of distinct health-subsystems within the same country creates large inefficiencies. Competition alone can not overcome this situation. Even worse, reforms in one subsystem frequently bear unwanted side-effects in another subsystem. One obvious example is the brain drain that takes place in public hospitals if private competitors pay qualified doctors higher wages. Hence, introducing stronger competition among public and private hospitals requires a consistent framework of incentives that minimizes unwanted side-effects and creates a level playing field for competitors.

In sum, competition among providers can work as an important element to increase allocative and technical efficiency in the health care sector. However, the success of this strategy depends heavily on the capacity of the third-party payers to structure the incentives for the providers in a consistent and economically efficient way. Can one expect this result from competing insurers rather than from a monopsonistic third-party purchaser?

\subsection{Competition among third party payers (insurers)}

The structure of the purchasing side is decisive for overcoming the challenges that health reforms in Latin America have to face. Unfortunately, experience in OECD-countries does not lead to a clear-cut recommendation for the choice between a monopsonistic or competitive model of third-party purchasing. Moreover, Latin America faces different problems and there are certain factors that limit reform options which are not evident in most OECD-countries.

The idea of competitive third party purchaser markets is that consumers select one of a number of insurers instead of automatically belonging to a monopsonistic third-party (usually the state). Consumer power thus should provide 
insurers with the right incentives to act ,as prudent buyers of care on behalf of consumers" (see above). This constitutes an important advantage in Latin America where the state as monopsonistic purchaser of care is discredited in the eyes of large parts of the population. Competition should ideally lead insurers to employ some form of managed care. Most prominently, insurers should selectively contract providers which they closely monitor to ensure cost-effective quality care (in analogy to some Preferred Provider Organizations in the USA). Or insurers may decide to completely integrate with providers so that they build up a network of own providers. This model usually restricts consumer choice but promises cost reductions in turn (the Health Maintenance Organization type). ${ }^{1}$ Efficiency gains in these managed care models rely basically on supplyside instruments, demand-side instruments like copayments should not play the dominant role (in contrast to simple insurance models).

The (limited) evidence with regard to efficiency gains of private insurers is rather disappointing. In Chile, which for a long time formed the prototypical case for relying on competing private insurers in Latin America, the private insurers (ISAPRES) are surprisingly hesitant in introducing selective contracts or integrated models of the HMO-type. „Freedom of choice“ seems to be the leading principle and ISAPRES require very high copayments especially for complex treatments. The overall costs in the private sector are rising, although unit costs in the few private clinics seem to be lower than in public hospitals. ${ }^{2}$

While in theory it is expected that competing purchasers perform well on the agency function, unregulated competition can not guarantee universal access. Insurers would calculate risk-adjusted premiums for patients and coverage would depend on the ability to pay these premiums. In other words: If societies want to ensure universal access of the population in a competitive third party purchaser market, they have to provide subsidies to poor and high-risk consumers (the „bad risks") or they have to regulate premiums.

Most governments have chosen the latter option as it is easier to manage. However, premium regulation induces insurers to pick the good risks („,cream skimming") which harms efficiency and again leads to uncovered people. There is ample evidence that ISAPRES in Chile extensively try to attract the good risks while making bad risks to go back to the public sector. Hence, a bulk of additional regulation and control is necessary to prevent cream skimming and to ensure universal access. The Chilean example, however, shows how difficult it is to prevent these practices as long as private insurers have a strong incentive to find a way to cream skim. Moreover, it can be observed there how strong (and

1 Interestingly enough, the integrated model comes close to many public bureaucratic regimes with the difference of course that consumers have the choice between different integrated delivery systems.

2 For more detailed evaluations of the Chilean reforms see e.g. Titelman; Uthoff (1999) and Larranaga (1997). 
successful) the political pressure of the big private insurance companies is to influence regulation in their interest, thus blocking any serious attempts to reform health legislation.

From a theoretical point of view, a risk-adjustment mechanism (RAM) is the most elegant way to deal with the problems. A RAM intends to balance competition and solidarity elements in health care financing. In practice they are still in an early stage. It will be difficult for public administrations in Latin America to effectively operate a risk-adjustment scheme that prevents creamskimming while allowing competition. Colombia is the only country which reformed its health system in 1993 including a RAM. The Colombian reformers tried hard to learn from international experience and built up an impressive regulatory framework for a competitive health insurance market while involving strong solidarity elements. It is too early for an evaluation, although serious difficulties in managing the RAM (and the complex system as a whole) have been reported. ${ }^{1}$

Compared to the monopsonistic model, there are other disadvantages: Transaction costs will be higher and it has to be measured if they outweigh efficiency gains. Administrative costs of the ISAPRES have been declining from over $40 \%$ to under $20 \%$ of their turnover, which is still much higher than in pure public systems. Smaller third-party purchaser have less buying power in the negotiations with providers which are sometimes acting in a coordinated manner. The same holds for buying medical inputs of big pharmaceutical firms. Unit costs for medical services could therefore rise in spite of possible efficiency gains. Small insurers will find it more difficult to coordinate the provision of different levels of care delivery (primary, secondary, tertiary) and to prevent duplication of capacities. In the case of some smaller markets in Latin America it is probable that the market will be of an oligopolistic structure. This need not harm competition, but paves the way for regulatory capture of the state since the few big insurers will constitute a politically and economically important agent.

The experience of Costa Rica is one example for a successful monopsonistic purchaser. However, it will not be easy to replicate this model in other countries of the region as Costa Rica (and even more the Caribbean countries) show some special characteristics which have facilitated the success of the model but are not given in other countries of the region. ${ }^{2}$

1 See Titelman; Uthoff (1999). Bertranou (1999) compares the health insurance reforms in Chile, Argentina and Colombia and provides institutional information as well as insights in crucial problems.

2 One should mention, among other aspects, the small geographical size of the country, the comparatively high rate of formal employment, the less unequal income distribution and the tradition of an effective state bureaucracy with little corruption and less waste of resources. 


\section{Conclusions}

Market-oriented reforms of the health care systems are not a panacea. However, they can form a useful element within a comprehensive reform package. Their effects depend very much on the way how the health care market is regulated or to put it differently: how the incentives for providers and third-party purchasers are structured.

Competition among providers has the potential to increase efficiency but could as well lead to cost escalation and even stronger allocative inefficiencies. The content of the contracts between third-party purchasers and providers is decisive for the result. This reasoning leads to the question if competition among thirdparties will induce them to design socially efficient contracts. Competition among third-party payers can lead insurers to act as prudent buyers of care on behalf of their consumers, thus ensuring efficiency gains to materialize. However, competitive third-party purchaser markets cannot guarantee universal access and will lead to segmented delivery qualities according to ability to pay. If it is desired to increase coverage and to improve health services especially for the lower-income group, then intensive regulation and a functioning riskadjustment mechanism is necessary. The question remains if this is easier or even worse to handle than a monopsonistic purchasing agency.

Unfortunately, the Latin American experience up to now does not provide a clear-cut answer. While the Chilean experience with competing insurers is rather disappointing due to regulatory deficits, it is too early to evaluate the (theoretically impressive) Colombian reform. On the other hand, Costa Rica is an example for a very good performance of a bureaucratic monopsonistic thirdparty purchaser.

Thus, it seems that the leading question of this paper cannot be answered completely. What emerges from the considerations above is the following conclusion: "Competition requires harmonization". This means that marketoriented reforms should be implemented only as a part of a reform-package that ensures clear and enforceable rules for all actors in the health care system. Different subsystems will probably persist in most countries, but reforms should provide a comprehensive framework that induces coordination of activities in the subsystems instead of provoking unwanted side-effects. If competition is introduced without providing clear rules and efficient regulation, negative outcomes are more likely to emerge, which will not serve to solve the problems of Latin American health care systems. 


\section{References}

BERTRANOU, Fabio M. (1999)

Are market-oriented health insurance reforms possible in Latin America? The cases of Argentina, Chile and Colombia, in: Health Policy, Vol. 47, pp. 19-36.

BOS, Eduard et.al. (1999)

Health, nutrition, and population indicators. A statistical handbook, Human Development Network. Health, Nutrition, and Population Series, The World Bank, Washington, D.C.

ENTHOVEN, Alain C. (1997)

Market-based reform of U.S. health care financing and delivery: Managed care and managed competition, in: Schieber, George J. (ed.): Innovations in health care financing, World Bank Discussion Paper No. 365, Washington, D.C., pp. 195-214.

IDB (1996)

Economic and social progress in Latin America 1996 report. Special section: Making social services work, Washington, D.C.

KATZ, Jorge / MIRANDA, Ernesto (1994)

Health care markets: their morphology, behaviour and regulation, in: CEPAL Review 54, pp. 7-25.

LARRANAGO, Osvaldo (1997)

Eficiencia y equidad en el sistema de salud Chileno. Serie Financiamiento del Desarrollo No. 49, CEPAL, Santiago de Chile.

LORA, Eduardo / OLIVERA, Mauricio (1998)

Macro Policy and Employment Problems in Latin America, Paper prepared for the Seminar: Employment in Latin America: What is the problem and How to Address it? IDB, Office of the Chief Economist.

MACEIRA, Daniel (1998)

Provider payment mechanisms in health care: Incentives, outcomes and organizational impact in developing countries, Major Applied Research 2, Working Paper 2, Abt Associates Inc., Bethesda, Maryland.

MEDICI, André Cezar et.al. (1997)

Managed care and managed competition in Latin American and the Carribbean, in: Schieber, George J. (ed.): Innovations in health care financing, World Bank Discussion Paper No. 365, Washington, D.C., pp. 215-231.

MESA-LAGO, Carmelo (1994)

Changing social security in Latin America. Toward alleviating the social costs of economic reform, Boulder \& London.

MILLS, Anne (1997)

Improving the efficiency of public sector health services in developing 
countries: Bureaucratic versus market approaches, in: Colclough, Christopher (ed.): Marketizing education and health in developing countries, Oxford.

STOCKER, Karen / WAITZKIN, Howard / IRIART, Celia (1999)

The exportation of managed care to Latin America, in: The New England Journal of Medicine, Vol. 340, No. 14, pp. 1131-1136.

TITELMAN, Daniel / UTHOFF, Andras (1999)

The health care market and reform of health financing, mimeo, CEPAL, Santiago de Chile.

TOBIN, James (1970)

On limiting the domain of inequality. in: Journal of Law and Economics, Vol. 13, pp. 263-77.

VAN DE VEN, Wynand P.M.M. (1996)

Market-oriented health care reforms: Trends and future options, in: Social Science and Medicine, Vol. 43, No. 5, pp. 655-666.

VAN DE VEN, Wynand P.M.M. et.al. (1994)

Editorial: Forming and reforming the market for third-party purchasing of health care, in: Social science and Medicine, Vol. 39, No. 10, pp. 1405-1412.

WORLD BANK (1998)

World development report, Washington, D.C. 
Hermann Sautter and Rolf Schinke - 978-3-631-75369-9

Downloaded from PubFactory at 01/11/2019 05:49:21AM

via free access 


\title{
The German Labour Market Institutions - Will They Meet the Demands of Globalization,and Europeanization?
}

\author{
Peter Rühmann"
}

\section{Some facts about the German labour market}

In his article „Unemployment and Labor Market Rigidities: Europe versus North America“, published 1997 in „The Journal of Economic Perspectives“, Stephen Nickell compared the labour market features of 20 OECD countries (15 European; 5 non-European) for the period 1983-96, and particularly for the subperiod 1989-94. With respect to the unemployment rate Western Germany ranked during both periods in the „best third“. Within the Euro-zone the unemployment rate still is - at least in Western Germany - comparatively low (see Figure 1). Table 1 shows that the wages (gross earnings) in Germany are higher than in Spain, France, or in UK. But productivity (GDP per worker) is high as well. Therefore, unit labour costs in Western Germany are lower than those of the other EU-member states. Thus, looking at these features, the (Western) German labour market appears to be both competitive and humane.

But there are some indications that may lead to a different assessment. The comparisons, mentioned above, were related to Western Germany. In Eastern Germany, for instance, the reported unemployment rate is about double the rate of Western Germany (in 1997 and 1998; see Deutsche Bundesbank 1999, Table IX.6). Moreover, since the early 70s, the Western German unemployment rate has been rising, with cyclical fluctuations. There are some signs of persistence in unemployment: after each recovery the minimum of the unemployment rate has been higher than in the preceding cycle (see Figure 1). Furthermore, the development of the so called Beveridge-curve shows that in the last decades the number of unemployed has grown without the number of vacancies declining simultaneously (see Figure 2 ). This may be interpreted as a worsening of the matching process in the German labour market. These developments cast doubt on the capability of the German labour market institutions to meet the demands of a changing environment. The present paper shall address this issue, after giving some informations about the characteristics of the German labour market institutions and after describing the challenges of the internationalization of the economies.

\footnotetext{
- Wirtschaftswissenschaftliche Fakultät, Universität Göttingen, Platz der Göttinger Sieben 3, 37073 Göttingen.
} 


\section{A look at the German labour market institutions}

Following Nickell, labour market regulations in Germany are strict. Generous conditions of unemployment benefits are combined with active labour market policies. Concerning wage setting, one has to take into account high union coverage, accompanied by a high degree of coordination of wage bargaining activites, particularly between employers.

\subsection{A highly developed welfare system}

It is the task of other sessions of the Summer School to introduce the details of the German welfare system. Social health insurance, social unemployment insurance, and public pension insurance are financed by contributions of employers and employees. It seems safe to say that the employees and their families still enjoy a high degree of social protection. Figure 3 plots the public expenditures on social protection in relation to GDP. These expenditures are higher than in the U.S., in Spain, or in UK, but the difference is important only with respect to the two former countries (at least in the 80s). The high social protection is at the expense of a wedge of about 42 per cent of gross earnings between the amount that the employer has to pay for an hour worked, and the payment received by the employee.

Assessing the consequences for the German labour market, one may stress the following points. First, the well developed welfare system might contribute to what is called in German „Sozialer Frieden" (social peace). As indicators for the presence of social peace in Germany one may take the rareness of strikes (see Franz 1996, 277, for an international comparison of days lost by strikes) and the high productivity of German workers. This is the positive aspect of the German system of social protection. On the other hand, the system may cause some disincentives to work. From the point of view of the workers, the difference between the direct payment they can get from work, and the social assistance ("Sozialhilfe") is small in many cases, sometimes even negative (Deutsche Bundesbank 1996, 65). With respect to the firms, labour demand may be restricted by the high contributions that have to be paid to the systems of social insurance. Therefore, one might guess that there should be some erosion of „normal employment“, i.e. of employment that is fully integrated within the welfare system.

\subsection{Collective bargaining}

Collective agreements in Germany between trade unions and employers' associations deal with almost every aspect of labour relations - most notably wages and working conditions (Soltwedel 1997, 178). About nine of ten German employees are incorporated into collective labour agrreements in spite of a union density of only one third (Franz 1996, 235, 242). More than four fifths of the union members are organized in unions at the level of industries, with the 
DGB („Deutscher Gewerkschaftsbund“) as parent organization (ibid, 241). Employers' associations covered (in the 70s) about half the companies with four fifths of all employees (ibid, 259). Franz reports of about 44 thousands agreements signed by unions: 28 thousands at industrie' level and 14 thousands at companies' level, with VW as the most prominent example (ibid, 237).

There have been some controversies about the degree of centralization of wage bargaining in Germany. According to Calmfors/Driffill $(1988,23)$ wage bargaining is intermediately centralized in Germany by reason of being mostly conducted at industries' level. But one has to take into account some more facts, namely the high degree of coordination of wage bargaining on the one hand (Nickell 1997, 68), and the considerable extent of wage drift on the other hand. This means that for a great part of the employees the effective wage is fixed above the standard wage at the level of companies (Franz 1996, 294). Lastly, some collective agreements at industries' level now contain opting-out clauses in case of economic difficulties of companies („Öffnungsklauseln") (Sachverständigenrat 1997, 207). Thus, the ranking of wage bargaining in Germany is not clear: it may be classified as rather decentralized as well as rather centralized.

Collective wage bargaining is legally acknowledged in Germany by a special law („Tarifvertraggesetz"). In this context one can find the following line of reasoning: workers, if they have to negotiate wages in isolation, are in a disadvantage vis à vis the employers. The allowance to form a kind of a cartel may help to bring about equal opportunities to both sides of the labour market (Halbach et al. 1994, 303). Moreover, central bargaining at industries' level instead of decentral bargaining at firms' level may reduce transaction costs. Furthermore, with equal wages at industries' level firms are forced to compete with each other through improvements in products, in technologies instead of competing through wage dumping. Lastly, with collective wage bargaining, conflicts will be kept out of the companies and it is expected that this will contribute to social peace. On the other side, collective agreements introduce an element of rigidity into the process of wage formation. With progress in international integration in the product markets, this rigidity will become more important than before because German companies now have to compete more intensively with foreign firms that are not included into the German system of collective wage bargaining.

\subsection{Workers' participation}

Two laws regulate workers' participation in Germany. The „Mitbestimmungsgesetz" (Codetermination Act) prescribes that in every joint stock company with more than 2 thousand employees, the employees and unions shall take half of the seats in the supervisory board of the company. The other half is taken by representatives of the capital owners. The president of the supervisory board is appointed by the capital owners. In the case of parity of votes, his vote 
is decisive. Furthermore, one director in the board of the company, the workers director („Arbeitsdirektor") has to be appointed de facto in consent with the employees and represents the interest of the employees within the board of the company. About 500 companies with 5 millions of employees fall within the scope of this law (Franz 1996, 245).

All companies with more than five employees are subject to the other law, the Works Constitution Act („Betriebsverfassungsgesetz") which prescribes a mandatory works council (see Addison/Schnabel/Wagner 1998). The members of this council are elected by the employees. A great number of these representatives are members of unions too. The works councils have to negotiate those work agreements that are not regulated by collective agreements. They have to be heard when the firm plans to terminate a labour contract. In case of dissent, the court has to decide. In short, the works councils can be regarded as ,the exemplar of collective voice - by reason of its explicit information, consultative, and participative rights" (Addison/Wagner 1997, 3).

Collective voice is assessed as a means to express ,discontent other than through quits, thereby reducing exit behaviour, lowering hiring and training costs, and improving firm-specific training investments. Improved communication and heightened workplace morale are of importance precisely because of the costs attaching to the use of external markets" (ibid.). On the other side, workers' participation may make it more difficult for the mangement of the firms to push through their decisions and thus to adapt to a changing environment. Moreover, one has to take into account the costs of workers' participation which are estimated by the „Institut der deutschen Wirtschaft“, an organ of German employers' associations, as amounting to 1 thousand DM per employee and year (IW 1998).

\subsection{Job protection}

Job protection in Germany is the result of a complex mixture of legislation, judicial law, and of collective agreements between trade unions and employers' associations (Franz 1996, 247). All companies with more than 5 employees are subject to dismissal notice regulations. The time spell increases with the number of years of service with a company up to 7 months (Winkler-Büttner 1997, 173). Moreover, each dismissal requires a statement of reasons either due to the conduct of the employee or due to economic difficulties of the company. In the case of mass dismissals there is an obligation to negotiate a social compensation plan („Sozialplan“) with the works council; the average severance payments amount to almost five times the monthly salary (Franz 1996, 247). Among the EU-member states the degree of job protection in Germany is assessed to be in the middle (Winkler-Büttner 1997, 172).

Employment protection will tend to reduce the inflow into unemployment and, since it makes firms more cautious about hiring, will also reduce the flow into 
work. Thus, the impacts on the unemployment rate will tend to cancel out (Nickell 1997, 66) while within companies long-term employment will raise at the expense of short-term employment. In the case of fluctuations of demand for their products, firms are forced to internal adjustment (for example by reducing the hours worked per employee) instead of adjusting in the number of persons employed (external adjustment). This may raise the costs of the firms. On the other hand, the prospect of long-term employment will be an incentive for the employees to invest in firm-specific human capital. This effect will improve productivity. In this way, the reduction in the capability of firms to adjust to demand fluctuations by changing the number of employees, may be compensated (see also Volkswagen 1998, 19).

There might be further effects on the labour market. Employment protection strengthens the bargaining position of the insiders at the expense of the unemployed. This may have contributed to the persistence of unemployment in Germany (as well as in most other EU-member states). Partly, this may explain the divergent labour market development of Germany in comparison to the U.S. or the UK.

\subsection{Policy actions with respect to labour markets}

a) Active labour market policy

According to the OECD one can group active labour market policy into five categories: public employment services, training, measures against youth unemployment, subsidised employment, and measures for the disabled (Schömann $1995,12)$. Of special importance for Germany are public employment services and expenditures for the reintegration of the long-term unemployed (training and subsidised employment) (see Figures 4 to 6). Expenditure involved in administration of labour market programmes as well as public services provided for counselling, vocational guidance, job-search courses, support of geographic job mobility and interregional or across-border mobility is classified into the category „public employment services“. Direct job creation in the public sector or in non-profit organisations, wage subsidies, and subsidised self-employment are used as a means to reintegrate long-term unemployed. To have a rough estimate, in 1998 at least 700 thousand persons have been supported by programmes intended for the reintegration of the long-term unemployed, i.e. more than one sixth in relation to the registered unemployed (Sachverständigenrat 1998, 89, Tab. 35: „Teilnehmer an beruflicher Weiterbildung plus Teilnehmer an beschäftigungsschaffenden Maßnahmen")

Programmes for the reintegration of long-term unemployed pursue the goal of developing employment-related skills either by formal training or by training on-the-job. But high levels of compensation while participating in a training programme or in public job creation schemes may raise the reservation wages of the persons involved in such programmes and thus may have disincentive effects 
on the labour supply in the "first labour market" as it is called in German (Schömann 1995, 3). When assessing the measures to reintegrate the long-term unemployed one has to take into account beside the positive effects on productivity this disincentive effect too, and, of course, the costs of financing the programmes.

b) Early retirement as a means of labour market policy

In Germany early retirement programmes are used as an instrument to influence labour supply. The conditions were changed frequently, according to the state of public finance and to the situation of the labour market. In principle, an employee retires at a time when he is too young to have a legal claim on pension insurance. In spite of having left labour force he receives unemployment benefits during the interim period. An additional payment of the company compensates, at least to some extent for the difference between the wage and the unemployment benefit. In the last years this instrument was used more and more to cushion the consequences of German unification as Figure 7 shows, (in 1992 almost 6 per cent of the labor force in Eastern Germany participated in early retirement programmes).

One may speculate whether early retirement programmes have contributed to some extent to the comparatively low rate of youth unemployment in Germany (see Figure 8). Certainly, in the first instance the vocational education in form of apprenticeships is important with respect to this success, for the unemployment rate of the skilled (,mittlere Qualifikation“) is considerably lower than that of the less skilled (see Figure 9). To summarize, retirement programmes in the first place seem to be a means to cushion the consequences of extreme negative labour market shocks.

\subsection{Summary}

German labour market institutions seem to be well-suited to increase labour productivity. High degrees of social peace and of job security, furthered by the well-developed welfare system, by collective bargaining, by workers' participation, and by job protection, give an incentive to the employees to invest in firmspecific human capital. Vocational education in form of apprenticeships promotes employment skills of the young and faciliates the entering into the labour market. On the other hand, the financial burden, as a consequence of financing the benefits of the welfare system, creates a wedge between the amount that the employer has to pay for an hour worked, and the payment received by the employee. Moreover, welfare benefits raise the reservation wage of the unemployed, thus reducing their incentive to participate in the labour market. It seems difficult to weigh these effects. But there is some kind of a market test. The intensification of international competition, particularly in European Monetary Union, the disincentive effects on labour supply, and the decreasing willingness of the people to bear the financial burden of the welfare 
system cast doubt, whether the German labour market institutions are sustainable in the future. Thus, it may be worth to have a look at the possible effects of EMU on the labour markets.

\section{Challenges of EMU}

\subsection{Policy changes}

Since the beginning of this year the member states of the European Monetary Union no longer have at their disposal the instruments of monetary policy or the ability to adjust exchange rates. The conduct of national budget policy is restricted. The Treaty on European Union imposes on member states of EMU an obligation to avoid excessive deficits. Each member is committed to keep its general government budget deficit within the limit of the reference value ( 3 per cent of GDP). However, a deficit over the 3 per cent value is considered exceptional (and therefore not excessive) when resulting from an unusual event. In the case of an excessive deficit, Article (EC) 104c(11) imposes sanctions. Although this excessive-deficit procedure has been speeded up and clarified by the Stability and Growth Pact, doubts about the effectiveness of sanctions remain. Thus, at the moment, one has to take into account some uncertainty about the degree of national autonomy in fiscal policy that will be preserved in EMU. In any case, one cannot expect that in the near future the central budget at the level of EMU will rise adequately to compensate for possible restrictions at the national level.

Thus, the Stability and Growth Pact tends to restrain the fiscal autonomy of the EMU-member states. At the same time, EMU probably will intensify the process of transnational economic integration and, thus, may further diminish the manoeuvrability of the member states.

\subsection{Increasing degree of economic integration}

While the process of economic integration is taking place globally (Feenstra 1998), the Single Market program in the European Union, which is intended to remove administrative barriers at the national borders, is intensifying the process of economic integration within the European Union. EMU also encourages greater economic integration. Within EMU, exchange-rate volatility is absent and cross-border transaction costs are reduced. The comparison of prices is facilitated by the use of a common currency. Therefore, in the EMU-zone product markets (for tradables) will become more and more integrated and national borders will progressively lose their importance for locational decisions of enterprises. These developments will expose the labour markets of the members of EMU to increased competition even if workers' inter-country mobility will be restricted in the foreseeable future by differences in language and in culture. or bv resistant administrative impediments at the borders. These 
effects have to be contrasted with the weakening of national autonomy in stabilization policies - in the absence of a substantial central budget.

\subsection{Consequences for the labour markets}

a) Diminishing differences in unit labour costs

Increased competition in product markets will reduce the price differences among the national markets. Thus, high-cost firms producing tradable goods, will find it more and more difficult to charge comparatively high prices. Instead, they have to adjust their costs to the lower level of their competitors. If they fail to do so, they cannot survive in the long-run. Thus, with the probably increased competition in the emerging EMU, one can expect a tendency towards price and cost equalization. Substantial differences in unit labour costs can only be maintained as long as corresponding differences exist in the other components of costs (for instance costs for raw materials, intermediate products or of financing the required capital). But these differences also will be removed by the intensification of competition. Thus, it seems safe to conclude that EMU will bring about an approximation of unit labour costs between the member states. As a consequence, differences in wages can survive in EMU only as far as they are backed by corresponding differences in productivity.

In judging the prospective development of productivity in the EMU-zone, one has to take into account that enterprises that build new factories can use the same technology in all member states of EMU. Furthermore, the EU is exerting considerable effort to bring infrastructures to a comparable standard in all its member states. On the other hand, one has to recognize that differences in the stock of human capital will persist for a long time. Thus, for a while at least, differences in labour productivity will be diminished but will not be completely removed. These considerations support the conjecture that there will be some progress of equalizing productivity at least at the marginal level of (new) investment.

In summary, one can expect the differences in prices of tradable goods and the gaps in average productivity that exist at the moment between member states to decrease within EMU, but not to be eliminated in a foreseeable span of time. Thus, there will be some room for equalizing wages without disturbing competition through provoking substantial differences in unit labour costs. However, in the next future full equalization of wages, presumably would lead to biases in the competitiveness of enterprises established in different member states.

b) Labour demand and intensified competition in product markets

A firm with some degree of monopoly power in the product market faces a downward-sloping demand curve for its product. Marginal revenue, therefore, is lower than the product price. The quantity produced and sold at the market is less than for a firm with the same cost curve, but trading in a perfectly competi- 
tive market. Consequently, the quantity of labour demanded will not be one that equates the real wage with labours' marginal physical product (as in the case of perfect competition) but is restricted to a lower quantity.

The effects on the labour market are demonstrated in Rühmann 1999, section 3.2. The intensification of competition within EMU shall raise firms' elasticity of demand in product markets, their demand for labour, and finally real wages. But this result may be offset if establishing EMU will induce a process of concentration among sellers. This would, contrary to the foregoing argument, increase the monopoly power of sellers in the product market, lessen in this market the individual demand-elasticity that is relevant to sellers' decisions, and diminish both labour demand and real wages.

In summary, integration of product markets may affect labour demand and real wages in two opposite directions either by inducing concentration among sellers and thereby lowering labour demand and real wages or by intensifying competition thus raising labour demand and real wages.

c) Increasing capital mobility and the bargaining positions in labour markets

In its World Labour Report 1997-98 the International Labour Office (ILO) expects, that the liberalization of investment regimes and the ability of firms to raise and spend money anywhere in the world increases the locational freedom of firms and thereby shift the balance of power away from labour to capital" (ILO 1997,70). If this conjecture is valid with respect to world-wide economic integration, it becomes even more valid in the context of EMU where the process of economic integration shall be further strengthened. Due to their high mobility, when compared to states and to the workforce, firms now can exert power in pre-investment bargaining with states and unions (ILO 1997,74-77). The importance of this shift in the bargaining position is not limited to countries that compete for new factories but extends also to those which shall be affected by the threat of losses in employment. Thus, exit potential of firms influences bargaining on wages and work conditions in both countries.

Generally, to exert the exit option will produce turnover costs comparable to those that result from the replacement of insiders by outsiders. The level of these costs depend upon the decision to be made. The costs will be lowest in case of a multinational enterprise (MNE) that has already factories in more than one country and can shift production without the need to set up new factories or to train workers intensively. For instance, car manufacturers like Volkswagen invite affiliates to an intra-company competition before they decide at what location they will produce a new model (IW 1999, 11). Therefore, particularly the MNEs' bargaining power will grow within EMU the more these companies become vertically integrated across the various member states.

When the firm achieves the capability to shift production abroad, then, in comparing this alternative with maintaining production in the home country, it 
has to take into account the turnover costs in addition to the wage paid abroad. The displacement will be advantageous to the firm when the wage paid at home exceeds the sum of the turnover costs and the (present value of the) wage paid abroad. A wage above this level is no longer attainable. The union is induced to agree to restrict the wage to to this level that is sustainable in the long-run. In this way, the exit potential of enterprises might influence bargaining on wages even if the actual change in the location of firms remains an exception (for a formal analysis compare Rühmann 1999, section 3.3).

According to the foregoing remarks, one can expect turnover costs to decrease more and more as MNEs pursue a policy of diversifying production with repect to its location. Thus, if in EMU the growing integration of product markets will further this process of vertical integration of firms, the bargaining position of unions in the nowadays highly industrialized countries may become severely restricted in future.

d) Effects of increasing capital mobility on labour market institutions

With firms having greater freedom in locational choice, states face stiffer competition when trying to attract new investments. Empirical studies indicate that multinational enterprises are sensitive to those labour-market institutions that may restrict their organizational freedom (ILO 1997, 72). For instance, collective bargaining frameworks are quoted as an institution that may hinder the U.S.multinationals to set up affiliates in a country. National authorities have to take this into account. Thus, institutions that are regarded by mobile firms as unfavourable from their point of view, will be put under pressure. Especially in EMU, where competition is intensive, institutions might be abolished even if they advance general welfare by economizing transactions costs.

These arguments lead to the conclusion that there might evolve a tendency to shift from centralized bargaining to bargaining at firms' level within EMU (Dohse/Krieger-Boden 1998, 69). In such a highly decentralized system, wage increases will have a direct effect on the competitiveness of the firms. Therefore, given this structure, comparatively high wage claims would reduce the prospects of the workers to stay employed by the firm. This consequence might effectively restrain wage increases in a system of wage bargaining at firms' level.

As a consequence of increasing economic integration in product markets, a tendency towards wage equalization should be expected within EMU, but it should fall short of full equalization of wages. If economic integration in product markets will lead to lower monopoly power of firms, real wages may increase on the average. But if, in contrast, this process results in higher concentration and more monopoly power of sellers on product markets, real wages may fall. The same result may be the outcome of a shift in bargaining positions in labour markets that would favour employers at the expense of employees. Pressures on wages might also result from a diminishing degree of centralization in wage bargaining. 


\section{Concluding remarks}

Despite their capability to promote high labour producitivity and high wages, German labour market institutions might get under strain within EMU. Probably, with an intensifying economic integration the bargaining power of the MNEs will increase at the expense of employees and unions. Furthermore, a shift from collective bargaining to bargaining at firms' level is to be expected. Moreover, the growing concentration among firms on a global level will tend to reduce real wages. This last development will be important particularly in Germany where, at the monent, competition in product markets is high. Therefore, it seems safe to conclude that the German employees, and in the first instance the skilled workers, will meet some difficulties when trying to maintain their present comparatively advantagous position. 


\section{References}

ADDISON, John T. / WAGNER, Joachim (1997)

The Impact of German Works Councils on Profitability and Innovation: New Evidence from Micro Data, Jahrbücher für Nationalökonomie und Statistik 216, 1-20.

ADDISON, John T. / SCHNABEL, Claus / WAGNER, Joachim (1998)

Works Councils in Germany: Their Effects on Firm Performance. Universität Lüneburg, Fachbereich Wirtschafts- und Sozialwissenschaften. Arbeitsbericht 194.

CALMFORS, Lars / DRIFFILL, John (1988)

Bargaining structure, corporatism and macroeconomic performance, Economic Policy 6, 13-61.

CHRISTENSEN, B. / SCHIMMELPFENNIG, A. (1998)

Arbeitslosigkeit, Qualifikation und Lohnstruktur in Westdeutschland, Die Weltwirtschaft, 177-186.

DEUTSCHE BUNDESBANK (1996)

Die Wirtschaftslage in Deutschland um die Jahreswende 1995/1996, Monatsbericht Februar 1996, 5-66.

DEUTSCHE BUNDESBANK (1999)

Monatsbericht Juli 1999.

DOHSE, Dirk / KRIEGER-BODEN, Christiane (1998)

Währungsunion und Arbeitsmarkt. Auftakt zu unabdingbaren Reformen. Kieler Studien 290. Tübingen.

FRANZ, Wolfgang (1996)

Arbeitsmarktökonomik. 3., überarb.u. erw. Aufl. Berlin.

HALBACH, Günter et al. (1994)

Übersicht über das Arbeitsrecht. 3., neubarb. u. erw. Aufl. Bonn.

ILO (International Labour Office) (1997)

World labour report 1997-98: Industrial relations, democracy and social stability. Geneva.

IW (Institut der deutschen Wirtschaft) (1998)

Betriebliche Mitbestimmung. Harmonie hat ihren Preis, iwd 24:43 vom 22.Okt. 1998.

IW (Institut der deutschen Wirtschaft) (1999)

Automobilindustrie: Gelungenes Comeback, iwd 25:11 vom 18.März 1999, 4-5.

NICKELL, Stephen (1997)

Unemployment and Labor Market Rigidities: Europe versus North America, The Journal of Economic Perspectives 11, No.3, 55-74. 
RÜHMANN, Peter (1999)

European Monetary Union and National Labour Markets. Center for Globalization and Europeanization of the Economy Discussion Paper 3. Göttingen.

SACHVERSTÄNDIGENRAT zur Begutachtung der gesamtwirtschaftlichen Entwicklung (1997)

Jahresgutachten 1997/98.

SCHÖMANN, Klaus (1995)

Active Labour Market Policy in the European Union. Discussion Paper FS I 95201. Wissenschaftszentrum Berlin für Sozialforschung. Berlin.

SOLTWEDEL, Rüdiger (1997)

Social Engineering in Europe: A German Perspective, in: J.T. Addison; W.S. Siebert (eds.), Labour Markets in Europe: Issues of Harmonization and Regulation, London.177-190.

VOLKSWAGEN (1998)

A Global Corporation. Volkswagen Kommunikation Wolfsburg.

WINKLER-BÜTTNER, Diana (1997)

Unterschiedliche Arbeitsmarktregulierung in Europa, Wirtschaftsdienst 77, 354358. 


\section{Appendix}

Table 1: Unit labour costs in 1997

\begin{tabular}{|l|c|c|c|}
\hline & $\begin{array}{c}\text { labour productivity } \\
\text { (1) }\end{array}$ & $\begin{array}{c}\text { gross earnings } \\
\text { (2) }\end{array}$ & $\begin{array}{c}\text { unit labour costs } \\
\text { (2) (1) }\end{array}$ \\
\hline DE (W) & 100,0 & 100,0 & 100,0 \\
\hline FR & 92,5 & 94,6 & 102,3 \\
\hline ES & 62,9 & 67,5 & 107,3 \\
\hline UK & 71,6 & 77,6 & 108,4 \\
\hline EU-11 & 85,1 & 89,1 & 104,7 \\
\hline DE (E) & 60,4 & 74,3 & 123,0 \\
\hline DE & 92,9 & 95,3 & 102,6 \\
\hline
\end{tabular}

Source: Jahresgutachten des Sachverständigenrats der gesamtwirtschaftlichen Entwicklung, 1998/99, p. 195 (Table 73) 
Figure 1: Unemployment in five OECD-countries

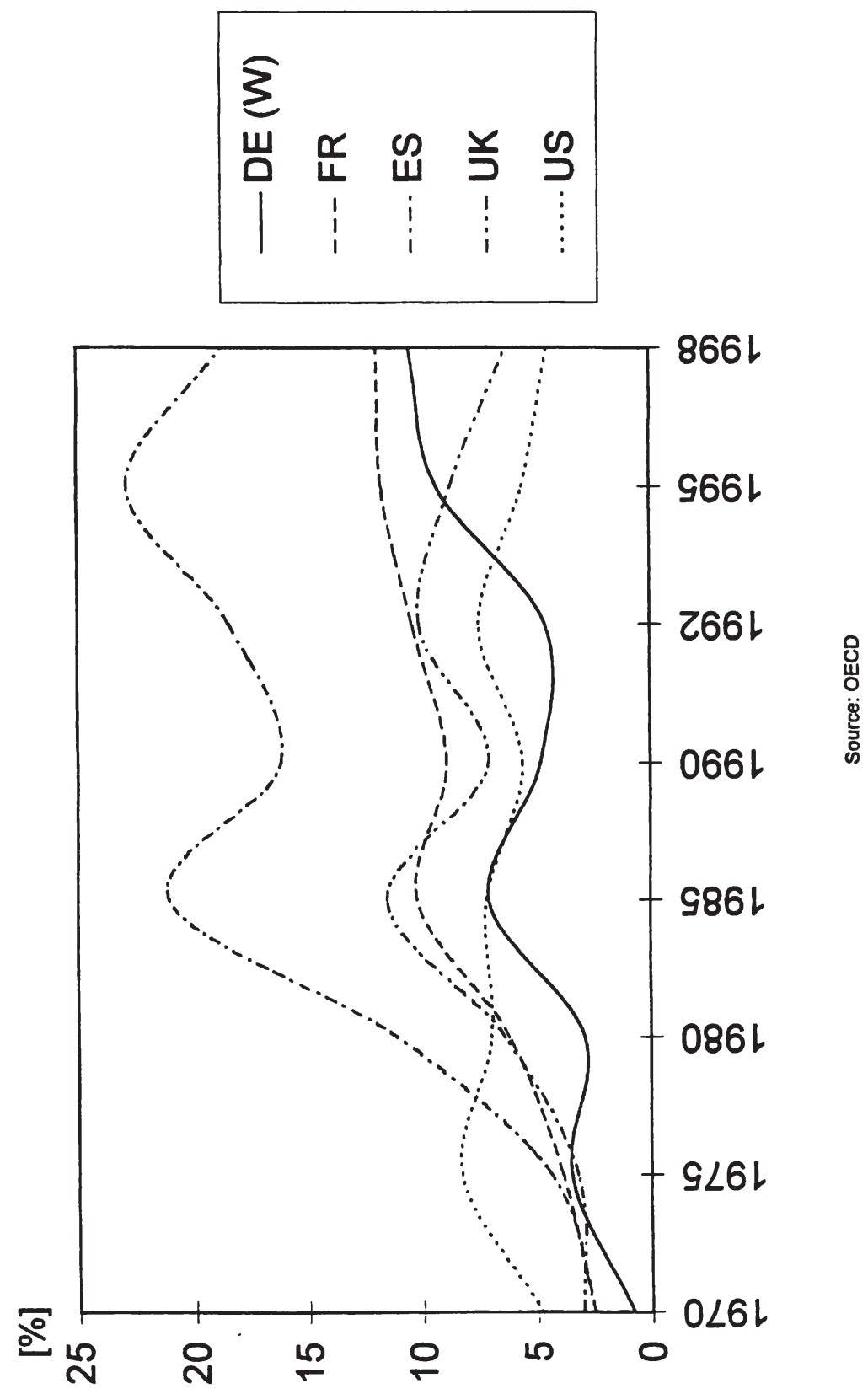


Figure 2: Beveridge curve for Western Germany 1961-94

\section{Vacancy rates}

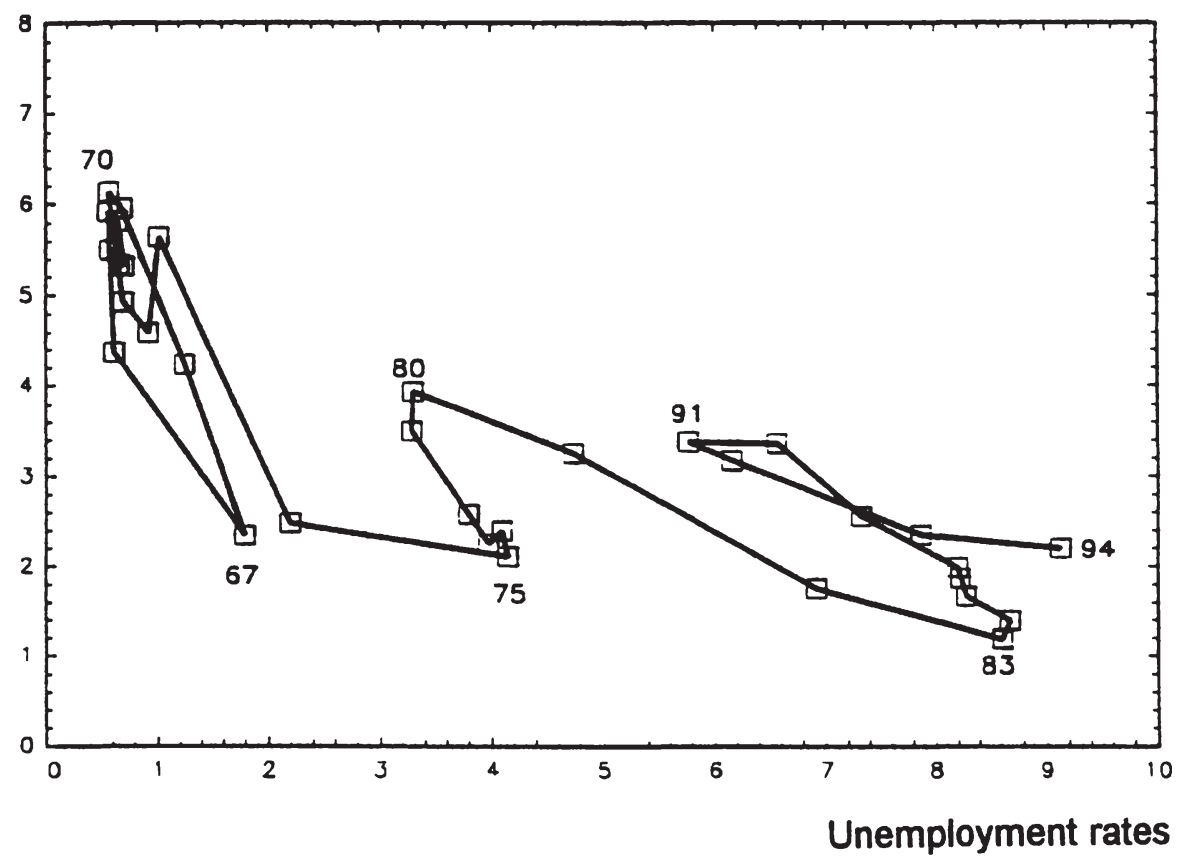

Source: Franz, Wolfgang (1996): Arbeitsmarktökonomik. 
Figure 3: Total public expenditure on social protection
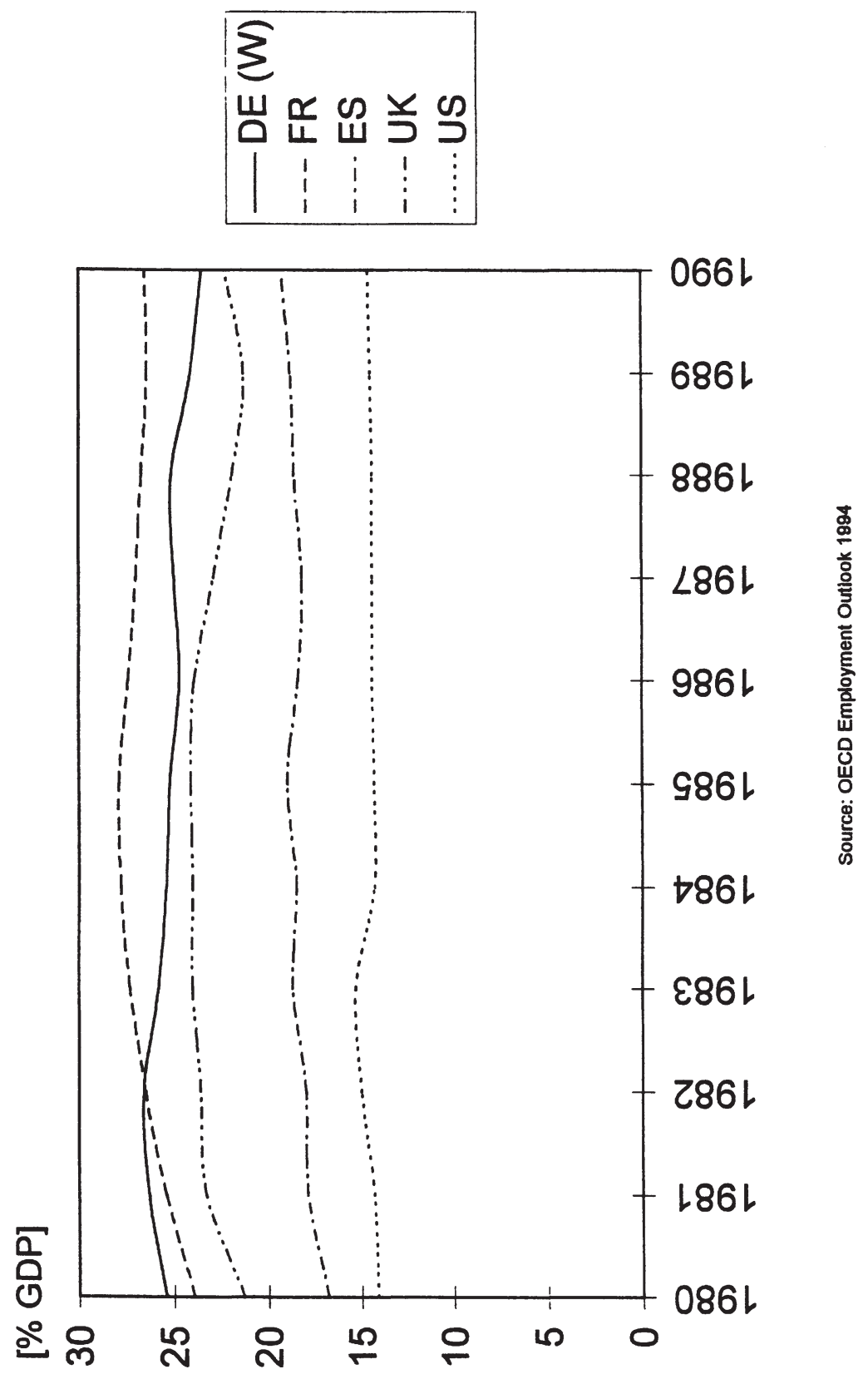
Figure 4: Active government expenditure compared with active expenditure per unemployment in 1992

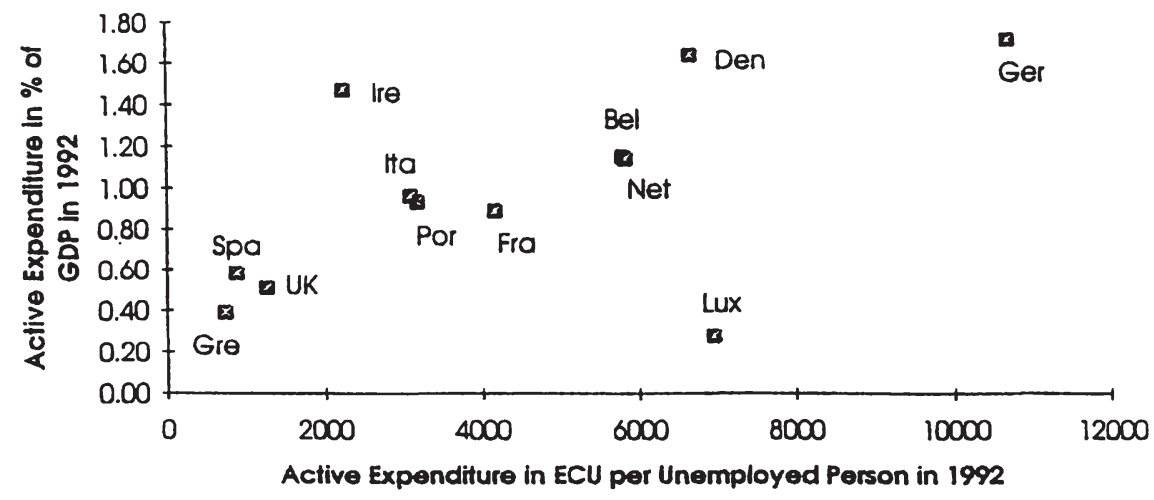

Source: Schömann (1995) 
Figure 5: Expenditure on public employment services in 1993 or latest year available

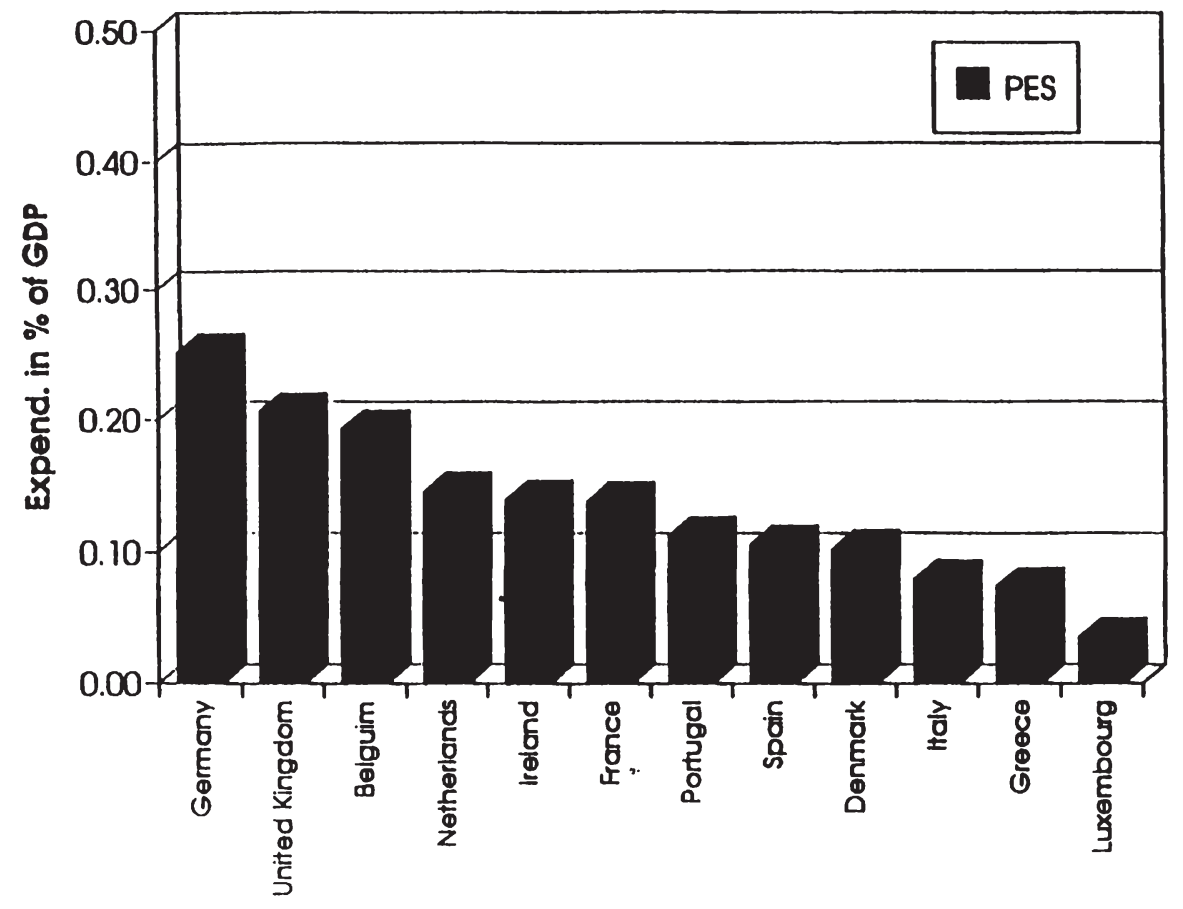

Source: Schömann (1995 
Figure 6: Expenditure on subsidesed employment and long-term unemployment

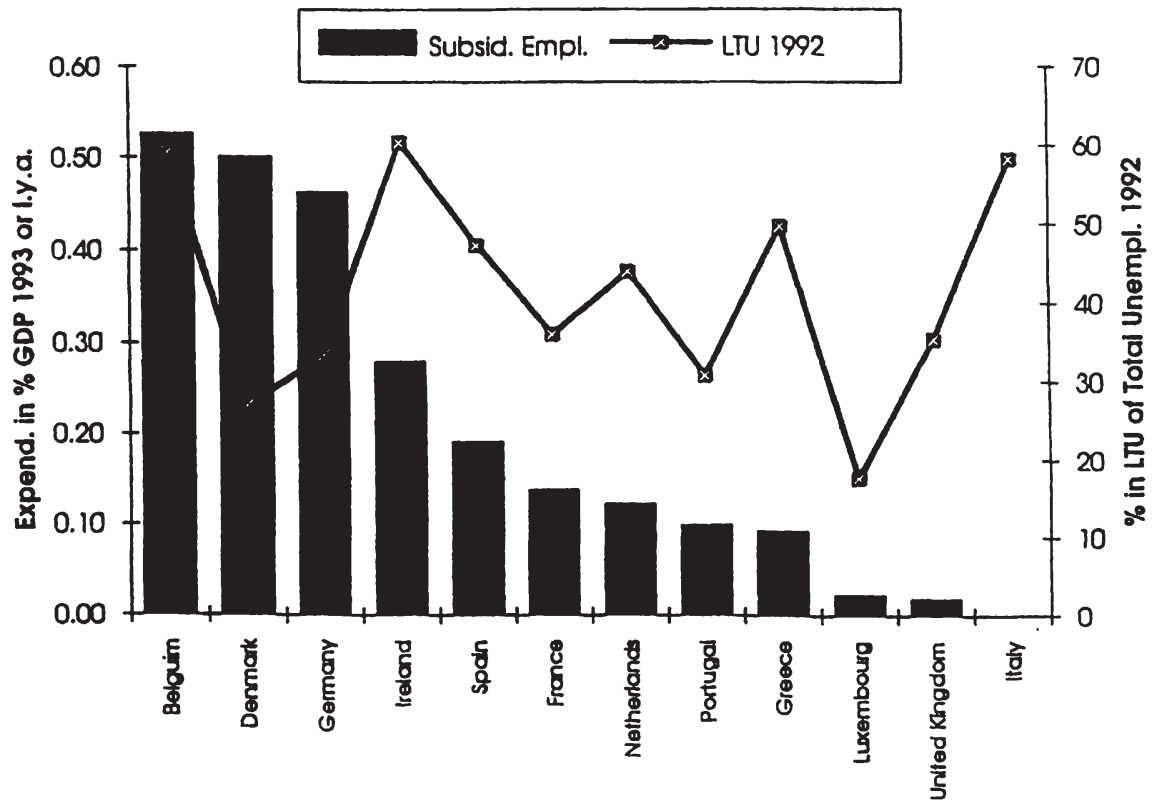

Source: Schömann (1995) 
Figure 7: German early retirement programme "Vorruhestand"

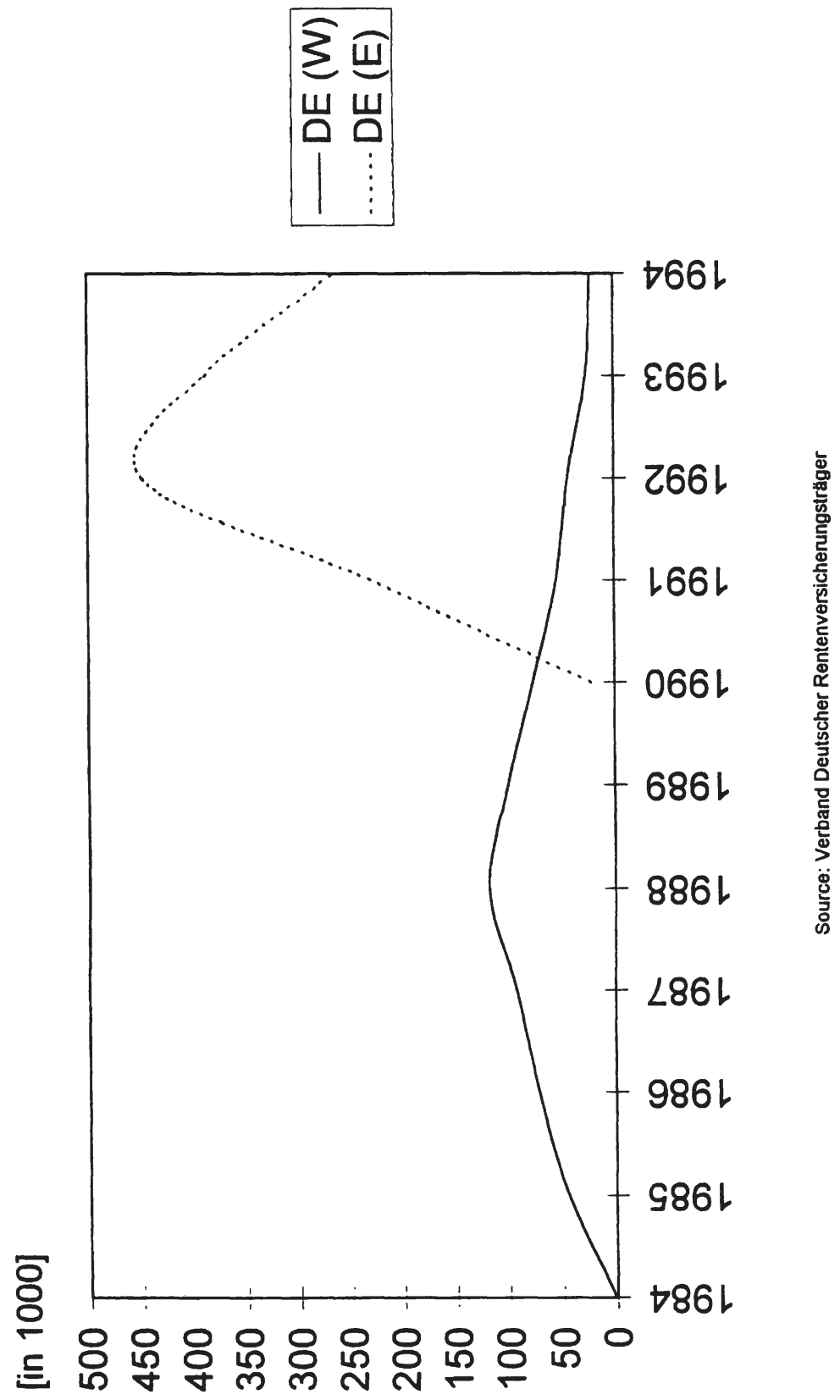


Figure 8: Youth unemployment from the age of 15 to 24
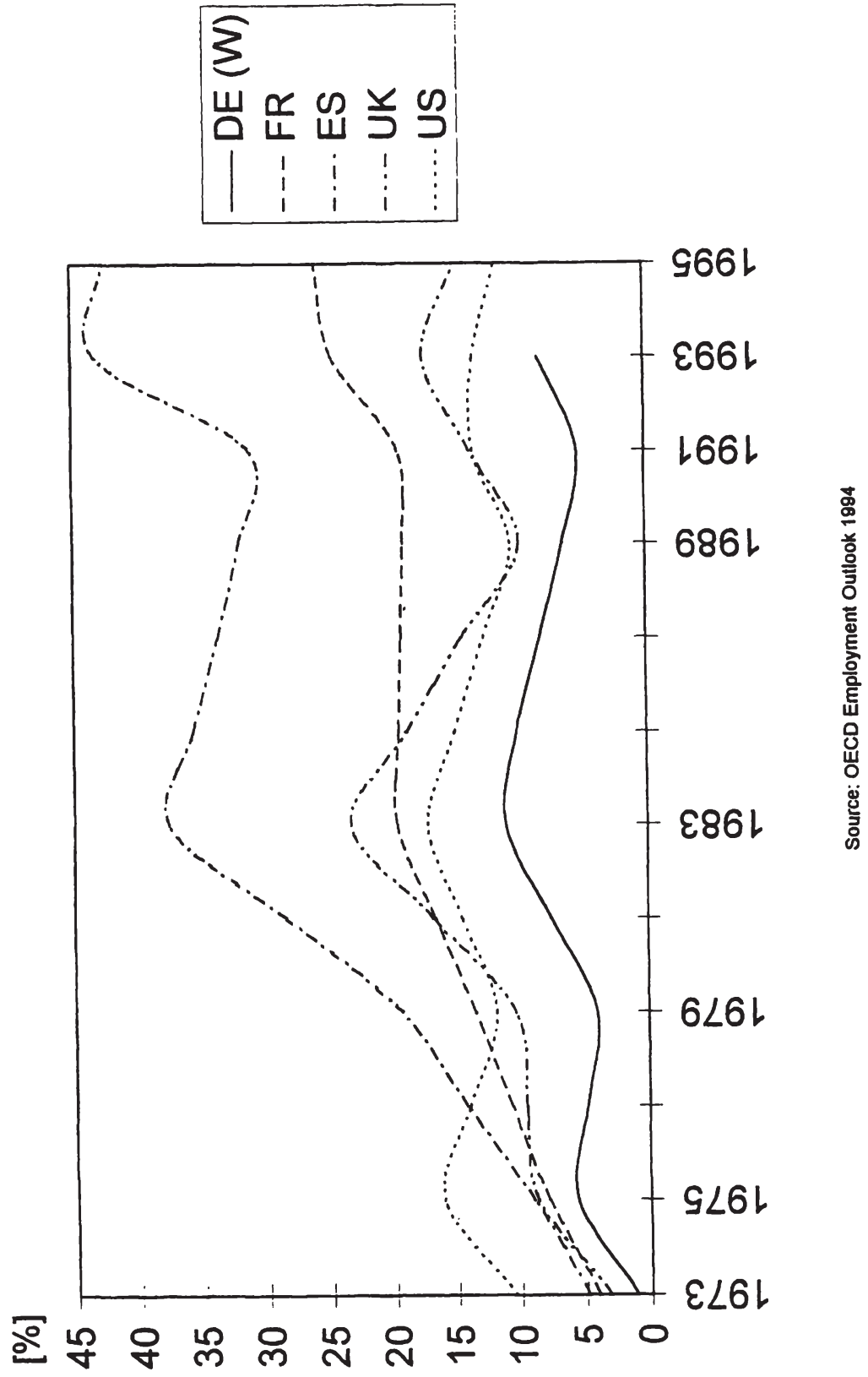

Hermann Sautter and Rolf Schinke - 978-3-631-75369-9 
Figure 9: Unemployment and qualification in Western Germany

[\%]

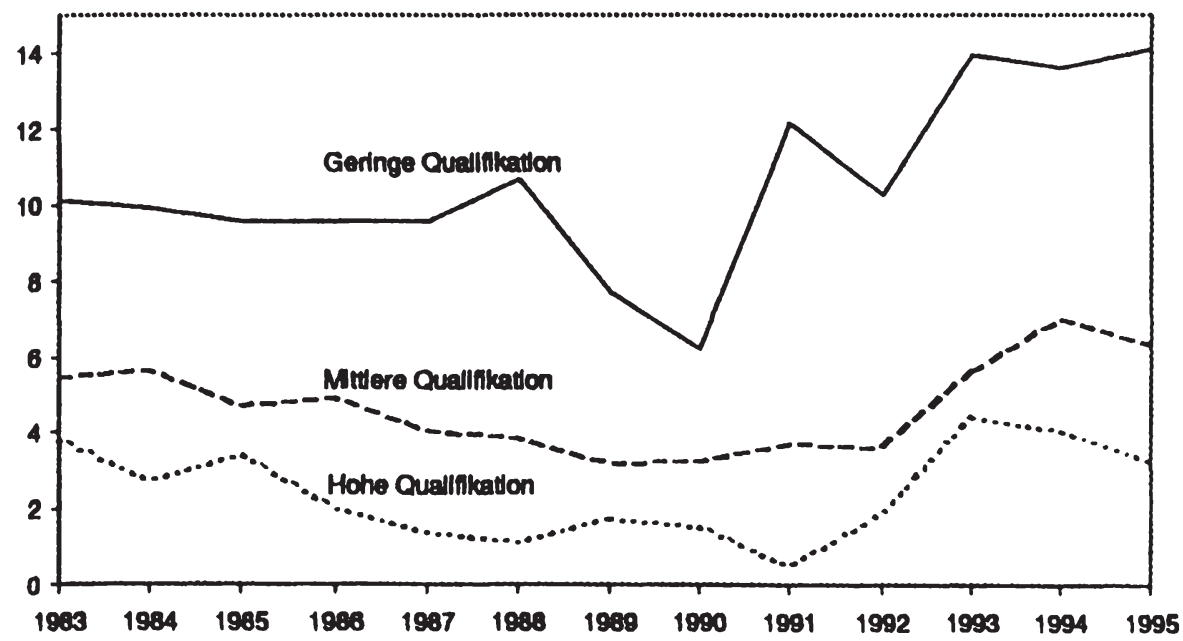

Source: Christensen/Schimmelpfennig (1998) 
Hermann Sautter and Rolf Schinke - 978-3-631-75369-9

Downloaded from PubFactory at 01/11/2019 05:49:21AM

via free access 


\title{
Old-Age Security: Design and Effects of Pension Schemes
}

\section{- Some Basic Aspects -}

\author{
Winfried Schmähl*
}

\section{Introduction: Pensions and pension reform - world-wide discussed topics}

The topic of pensions and pension reform is high on the political agenda in many countries. In Europe this is not very astonishing because of the already high percentage of elderly people in the population, the further ageing of the population and its effects on costs of pension provision. Ageing of the population makes pension provision more costly. This is quite similar for example in Japan.

But the topic of old-age security becomes more and more important also in many countries with today relatively young populations. One reason for this is that family structures are changing in the process of economic development. In countries, where old-age security is mainly based on the extended family, this type of informal old-age security may not be anymore sufficient in the future. Therefore, more and more formal arrangements become necessary.

In a number of countries with formal schemes of old-age security, important structural changes - beside demographic ageing - required a change of pension schemes themselves. For example, in some Latin American countries the design and management of pension schemes was insufficient and could not fulfil the main tasks of a pension scheme, namely to secure income during non-working periods of the life cycle in case of invalidity or at an age at which a society does not expect people to earn their living from work.

In former socialist countries tremendous structural changes in politics and in the economy - the restructuring of a planned economy towards a market economy also affect pension arrangements. Pensions in socialist countries mainly were provided by public schemes, often closely linked to the state budget. Now private and capital funded schemes are developing. Necessary preconditions for such pension schemes, however, are an adequate infrastructure (e.g. concerning financial markets) and relatively stable economic conditions (e.g. low inflation rates). These preconditions have to be established before privately managed capital funded schemes really can become effective.

* Zentrum für Sozialpolitik (ZeS), Universität Bremen, Parkallee 39, 28209 Bremen. 
These few remarks underline the political, economic and social importance of the topic. In this paper some general aspects of pension policy are discussed. The structure of the paper is as follows: It starts with a short overview of factors that influence volume and structure of old-age security in a country (2.) Then the channels for economic effects of pension schemes are briefly mentioned (3.) A major part of the paper deals with the design of pension schemes, outlining basic options and concepts as well as important instruments (4.) Finally some aspects of different financing methods - pay-as-you-go financing and „capital funding" - are discussed (5.). This is a major topic in pension reform debates in many countries and a dominating aspect in economics.

\section{Factors influencing volume and structure of pension schemes}

\subsection{Types of influencing factors}

Structure and volume of pension schemes are influenced by many factors, namely demographics, economic factors, political decisions as well as by decisions of courts (jurisdiction). This is illustrated in Figure 1.

Figure 1: Factors influencing old-age protection (pension schemes)

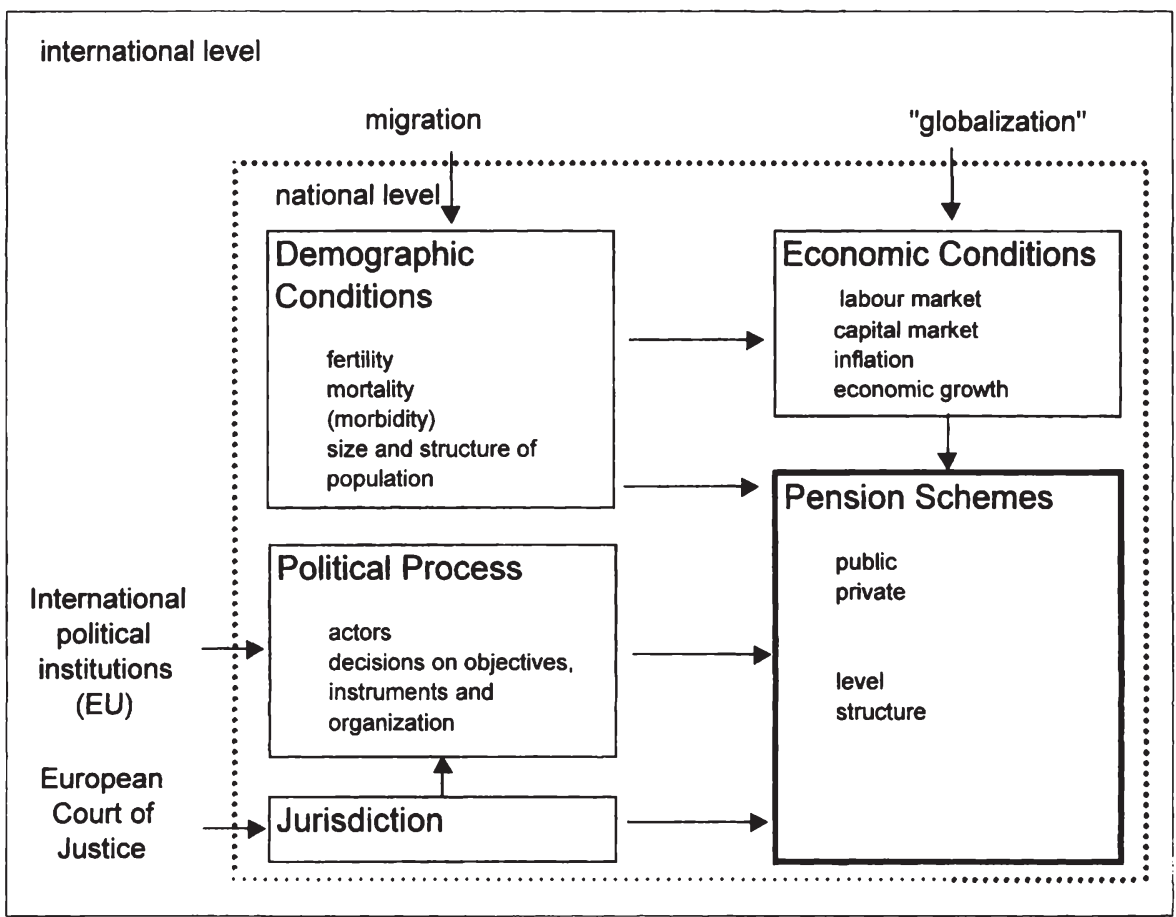


Pension schemes are mostly organised on the national level, not as inter- or supranational schemes. Therefore, major determinants of pension schemes operate on the national level - mainly demographic, economic and political factors. But there are also influencing factors from outside. International economic competition is one factor. It directly influences national economic variables, but often also political decisions (e.g. political pressure to reduce nonwage labour costs). ${ }^{1}$ The integration of countries into the world economy which were for a long time „behind the iron curtain" is one reason for an intensified economic competition. "Globalisation", which becomes most obvious on financial markets, is another catchword.

Migration affects population size and structure, but can also directly and indirectly affect economic conditions (e.g. via the labour market). It is obvious that not only the number, but also e.g. the age structure and the qualification of the migrant population is important for example for integrating immigrants into the labour market as well as for the financing conditions of pension schemes (e.g. via the number of contributors and beneficiaries). ${ }^{2}$

Pension schemes also can be influenced by political decisions on a supranational level (e.g. by institutions of the European Union) as well as by decisions of supranational courts (e.g. the European Court of Justice). These few remarks already illustrate the complexity of factors relevant for structure, volume and development of pension schemes in a country. Pension schemes can be organised and administered by the state, by employers and/or private firms. This will be discussed later together with the design of pension schemes. Many different types of actors are deciding on pension matters, for example on the coverage of pension schemes, their financing and on benefits. It is not possible to deal with all these factors. In the following paragraph only a few remarks mainly on demographics are made because this - at least in Europe - is a major reason for debates on pension reform. ${ }^{3}$

\subsection{Demographic development - the ageing of populations}

The three key factors for demographic development are

- fertility,

- mortality and

- migration.

1 See for more details Schmähl (1995a).

2 The effects on pension schemes depend also on the design of the schemes and whether pensions can be exported if people go back e.g. to their home country. For a detailed analysis see Schmähl (1995b).

3 Demographic development - and especially the ageing of the population - affects also other areas of social security like health insurance and provision in case of long-term care. 
Figure 2 illustrates a stylised development of these three factors in a long-term perspective, labelled by demographers as the „demographic transition“.

Figure 2: Stylised model of first and second demographic transitions

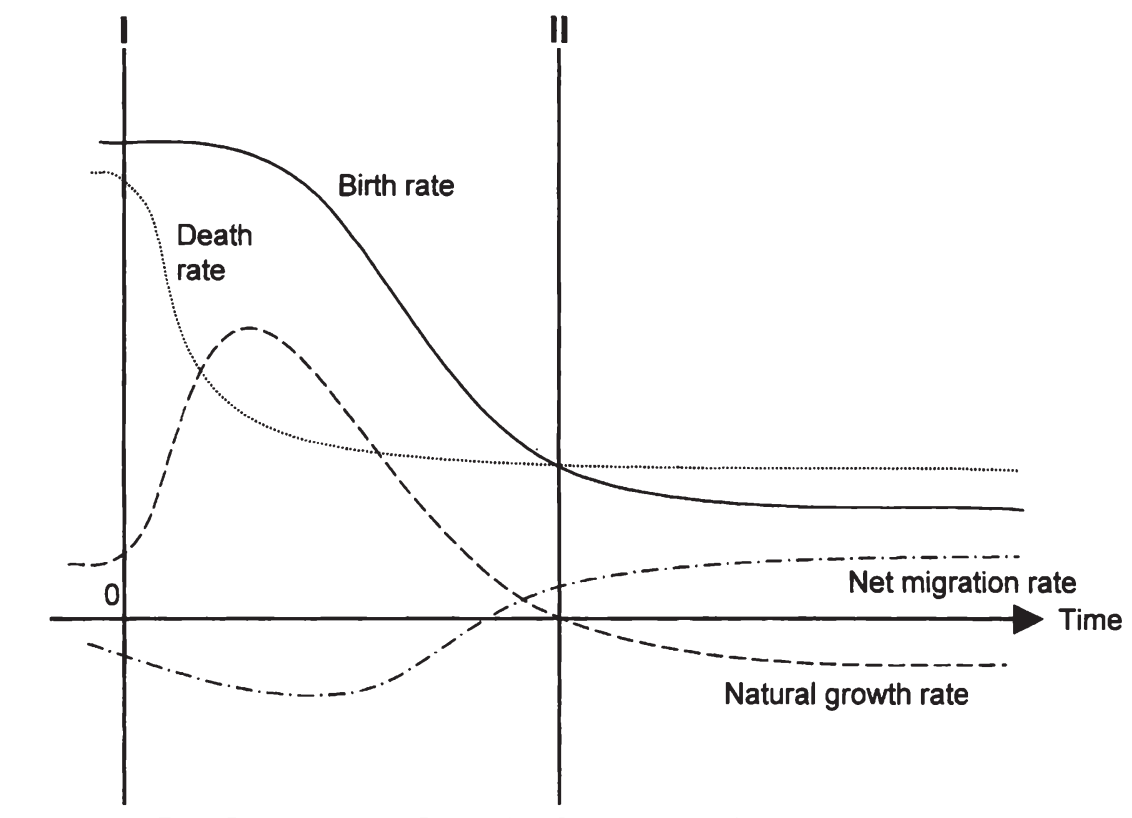

Beginning First Transition Beginning Second Transition

Source: Stylised figure following van de Kaa 1999: 30

In early phases of development high birth rates are accompanied by high mortality rates. Then mortality declines, while fertility behaviour reacts with a time-lag. This results in an increase of the natural growth rate of the population and often is accompanied by a process of migration, for example because of difficult living conditions. Over time fertility as well as mortality rates further decline. Especially if fertility rates are below the replacement level, population size shrinks - if there is no net migration into the country.

If we look at European countries, fertility rates in general are below replacement ${ }_{\text {level }}{ }^{1}$, mortality rates decline. Especially life expectancy of the elderly people increased during the last decades. This stimulates a process of population

1 An exception is Ireland with its mainly catholic population. However, (catholic) religion and high fertility rate must not go hand in hand, as Italy clearly demonstrates: In Italy the fertility rate is now below the already low German fertility rate. 
ageing. In some countries even a reduction in the absolute size of the population is expected.

In Germany the fertility rate has been about $1 / 3$ below the replacement level since several decades. The reduction of the absolute number of people in Germany was avoided up to now by net migration. For the future development the assumptions concerning the number of migrants are an important factor in determining the year when a reduction in population size may start.

Table 1 gives information on the year when - according to comparable calculations of Eurostat - an absolute reduction of the number of people in European countries is expected.

Table 1: First year of absolute reduction of population size in countries of the European Union

\begin{tabular}{|l|l|}
\hline year & country \\
\hline 2008 & Italy \\
2013 & Germany \\
2014 & Spain \\
2023 & EUR 15 \\
2026 & Finland \\
2029 & Austria \\
2030 & United Kingdom \\
& Ireland \\
2032 & Belgium \\
2034 & Denmark, France \\
2038 & The Netherlands \\
2040 & Greece \\
\hline
\end{tabular}

Source: Eurostat

But the change of the age structure of the population is much more important for pension schemes than the absolute number of people. Concerning the age structure there exist, however, remarkable differences between countries or regions of the world. Beside the age structure also the speed of structural change is important. Rapid structural changes can be major challenges for economic and social policy. 
Existing differences in the age structure as well as in its change are illustrated by some figures from population projections of the United Nations (Table 2). Although one always can debate the assumptions underlying such projections, the figures nevertheless illustrate very clearly marked differences in the present age structure as well as in the speed of change in age structures.

Table 2: Age structure in different regions of the world $1990-2040$

\begin{tabular}{|c|c|c|c|c|c|c|c|}
\hline & \multicolumn{3}{|c|}{$\begin{array}{l}\text { Portion of persons } \\
\text { age } 65 \text { and older in } \\
\text { the whole population } \\
\text { in per cent }\end{array}$} & \multicolumn{3}{|c|}{$\begin{array}{l}\text { Old-age dependency } \\
\text { ratio }(65 / 15)= \\
65 \text { and older } / 15-64 \\
\text { in per cent }\end{array}$} & \multirow[t]{2}{*}{$\begin{array}{l}\text { Change of old- } \\
\text { age dependency } \\
\text { ratio } 2040 / 1990 \\
\text { in per cent }\end{array}$} \\
\hline & 1990 & 2030 & 2040 & 1990 & 2030 & 2040 & \\
\hline World & 6,2 & 10,9 & 13,1 & 10,0 & 16,7 & 20,3 & 103 \\
\hline Europe & 12,6 & 21,4 & 23,3 & 18,9 & 34,4 & 38,9 & 106 \\
\hline Asia & 4,9 & 10,7 & 13,7 & 7,9 & 16,0 & 20,9 & 165 \\
\hline Africa & 3,1 & 4,6 & 5,9 & 5,9 & 7,5 & 8,9 & 51 \\
\hline $\begin{array}{l}\text { Latin America } \\
\text { and the } \\
\text { Caribbean }\end{array}$ & 4,8 & 11,2 & 14,1 & 8,1 & 17,0 & 21,7 & 168 \\
\hline $\begin{array}{l}\text { North } \\
\text { America }\end{array}$ & 12,4 & 19,7 & 20,7 & 18,8 & 32,4 & 34,2 & 82 \\
\hline $\begin{array}{l}\text { Australia and } \\
\text { Oceania }\end{array}$ & 9,2 & 15,0 & 17,2 & 14,2 & 23,6 & 27,5 & 94 \\
\hline
\end{tabular}

Source: Own calculation based on UN (1994) data.

As can be seen from Table 2, the percentage of people aged 65 or older in the total population is already highest in Europe and will increase further. Europe according to these projections - will remain the region with the highest percentage of elderly in the population during the next five decades. But even those regions with a low percentage of elderly today will be confronted with an absolute and relative increase of elderly people. Asia and Latin America illustrate this very clearly. However, there are differences within the regions (only to mention China and its population policy resulting in a decrease of the fertility rate and a pronounced aging of the population later). In Asia or Latin America in 30 to 40 years the „level" of the percentage of the elderly will be about as high as today in Europe, but the rate of change is much higher in these regions compared to Europe. 
Concerning the determinants of population development and structure only the changes in life expectancy are taken up here. Although migration obviously is the most unknown factor - which is influenced by pull and push factors and also especially by political decisions in migration policy ${ }^{1}$ - the development of mortality in recent years was one of the most surprising factors in some countries. Because of an already low infant mortality in Western Europe an increase in life expectancy mainly is now the result of a reduction in mortality of elderly people.

To illustrate this with some data from West Germany, Table 3 clearly shows that remaining life expectancy at age 65 increased from 1960 to 1995 at a higher rate than life expectancy at birth. Figure 3 shows that the development of life expectancy of persons at age 65 was much higher during the last three decades than in the years before. And life expectancy of women which was already higher than life expectancy of men increased even more than life expectancy of men. Therefore the already existing gap in life expectancy according to sex widened even more. This is important for pension expenditure because women will receive an own pension for a longer time and if there exist widow's pensions they will (ceteris paribus) increase by number and length of benefit payment, too.

Table 3: Life expectancy at birth and at age of 65 in West Germany 19601995

\begin{tabular}{|l|l|l|l|l|}
\hline Life table & \multicolumn{3}{|c|}{ At birth } & \multicolumn{2}{c|}{ At age of 65 } \\
\hline & Males & Females & Males & Females \\
\hline $1959 / 60$ & 66.69 & 71.92 & 12.38 & 14.37 \\
\hline $1993 / 95$ & 73.53 & 79.81 & 14.79 & 18.57 \\
\hline & \multicolumn{5}{|c|}{ Change in percent } \\
\hline $1960 / 95$ & 10.3 & 11.0 & 19.5 & 29.2 \\
\hline
\end{tabular}

Source: Enquete-Kommission (1998: 45, table 14).

A much debated topic is whether the decline in mortality will be accompanied also by a decline in morbidity. Will people live longer and have a longer period of good health conditions, too? Will there be a „compression of morbidity“??

This is also a topic in debates on the enlargement of the European Union, e.g. by Turkey.

2 For an overview on different assumptions concerning development of mortality and morbidity see e.g. Markides (1993), Manton et al. (1997). 
Figure 3: Development of life expectancy at age 65, West Germany

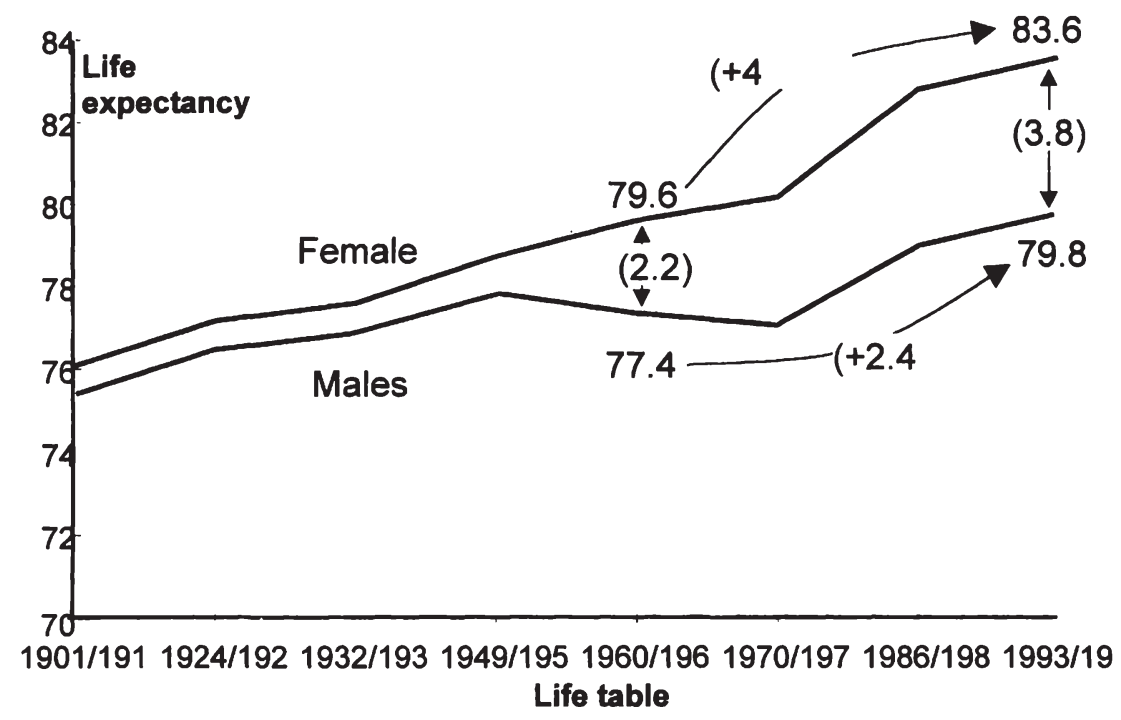

Source: Statistisches Bundesamt (Federal Statistical Office) 1997b: 76.

\subsection{Old-age dependency ratio}

An indicator often used to illustrate the „burden“ of the elderly in an economy and especially in pension policy is the „old-age dependency ratio“ (ADR). It is defined as number of elderly people above a certain age limit compared to the number of those in their „economically active phase“, i.e. in their (potential) years of employment. ${ }^{1}$ It is obvious that this is not a pure demographic indicator because the definition has to take into account at what age usually or on average the employment (earnings) phase in the life cycle starts and when usually or on average it ends (statutory or effective retirement age). Therefore, a realistic definition will take into consideration the specific conditions of a country. Nevertheless, for international comparisons often an identical definition of ADR is used, like in Table 2 for different regions of the world.

The absolute numbers of ADRs differ, but also their development over time. From Table 2 one clearly can see that the rate of change is highest in Asia and Latin America, while at present the ADR is much lower than in Europe.

The length of the different phases of the life cycle - education and preparing for employment, employment, retirement - changed remarkably in many European

I Insofar „economically active“ is misleading because economic activity is not only (gainful) employment. 
countries: The employment phase was compressed by more years of education and earlier exit from employment. The retirement phase became longer because of earlier retirement and increasing life expectancies. These structural changes are interwoven with the demographic changes due to low fertility rates which reduces the base of the population „pyramid“ (see Figure 4), changing its shape - in a long-term view - from "tree" to "mushroom". This is especially important for pay-as-you-go financed pension schemes, but also affects funded schemes. This will be discussed in the last section of this paper.

Figure 4: Restructuring the life cycle

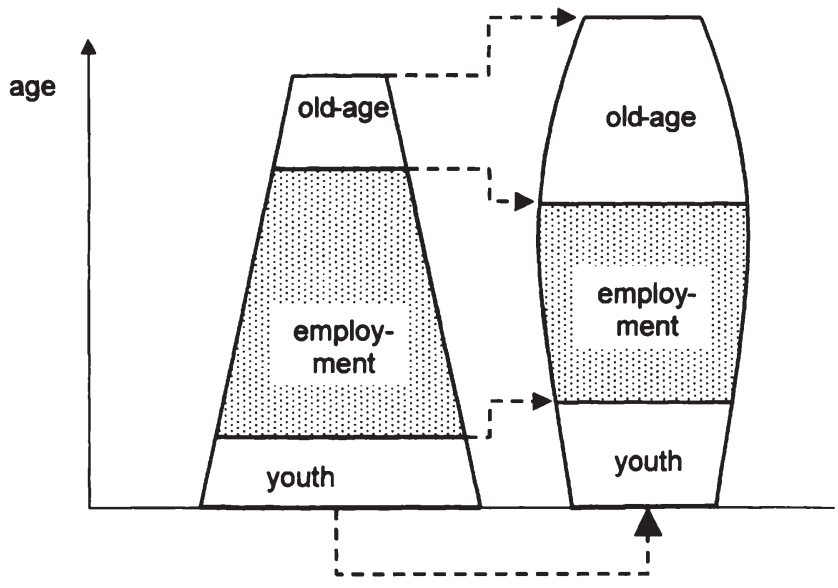

The ADR is only a rough indicator in pension policy, because for financing issues the number of beneficiaries (pensioners) and the number of contributors (employed persons covered by the pension scheme) are decisive. The ratio of these two variables can be called "pensioner ratio“ (PR) (sometimes also labelled „systemic dependency ratio“). Labour market conditions - employment and unemployment rates, labour force participation rates - and the design of the pension scheme (e.g. definition of coverage and other legal rules, like retirement ages) are among the factors relevant for the development of the „pensioner ratio". 
The ageing of the population is in many countries - for example in Germany also accompanied by an ageing of the workforce. There are (relatively) more older workers. But in many countries labour force participation of older workers decreased, exit from the labour market as well as retirement ages was realised earlier and pushed the pension ratio upwards in addition to the effects of demographic ageing.

There are many reasons for this development. One is the design of legal rules. In Germany the introduction of new possibilities for early retirement without actuarial reductions from the (full) pension benefit stimulated the reduction of labour force participation rate of male employees. Although empirically it is difficult to disentangle different influencing factors for retirement behaviour, the development of the male labour force participation rate at age 63 after introducing the possibility to retire already at 63 (instead of 65) in Germany in 1973 clearly demonstrated that a link between legal rules and behaviour of employees exists: Labour force participation of men dropped within 2 years after the introduction of the new rules from $67 \%$ to $47 \%$ and during the next few years to about $20 \%{ }^{1}$

\section{Economic effects of pension schemes - an overview}

In many developed countries public as well as private pension schemes have important microeconomic as well as macroeconomic impact. For example expenditure of the statutory social insurance in Germany - which is the largest pension scheme in Germany - is about $10 \%$ of GDP. It is obvious that the economic effects of pension schemes and of pension reform measures cannot be neglected. In trying to analyse possible effects a broad range of aspects has to be taken into consideration, effects on production and income in the official economy as well as in the shadow economy, on income distribution and income redistribution as well as on spending of income (consumption, saving, investment). Pension schemes affect supply and demand, volume and structure of labour markets as well as of capital markets.

Figure 5 illustrates in a simple manner the different channels for possible (economic) effects. It would be much beyond the scope of this paper to discuss these aspects. It should only be underlined that pension policy is not - as often mentioned - only a matter of income redistribution. The debate on funding methods clearly demonstrates that e.g. also the effects on investment, production and economic growth are an important topic as well as labour supply (for example via retirement ages) and labour demand (for example via social insurance contributions paid by employers and the effect on labour costs).

1 For more details see Jacobs and Schmähl (1989). 
Figure 5: Channels of old-age security in influencing economic variables

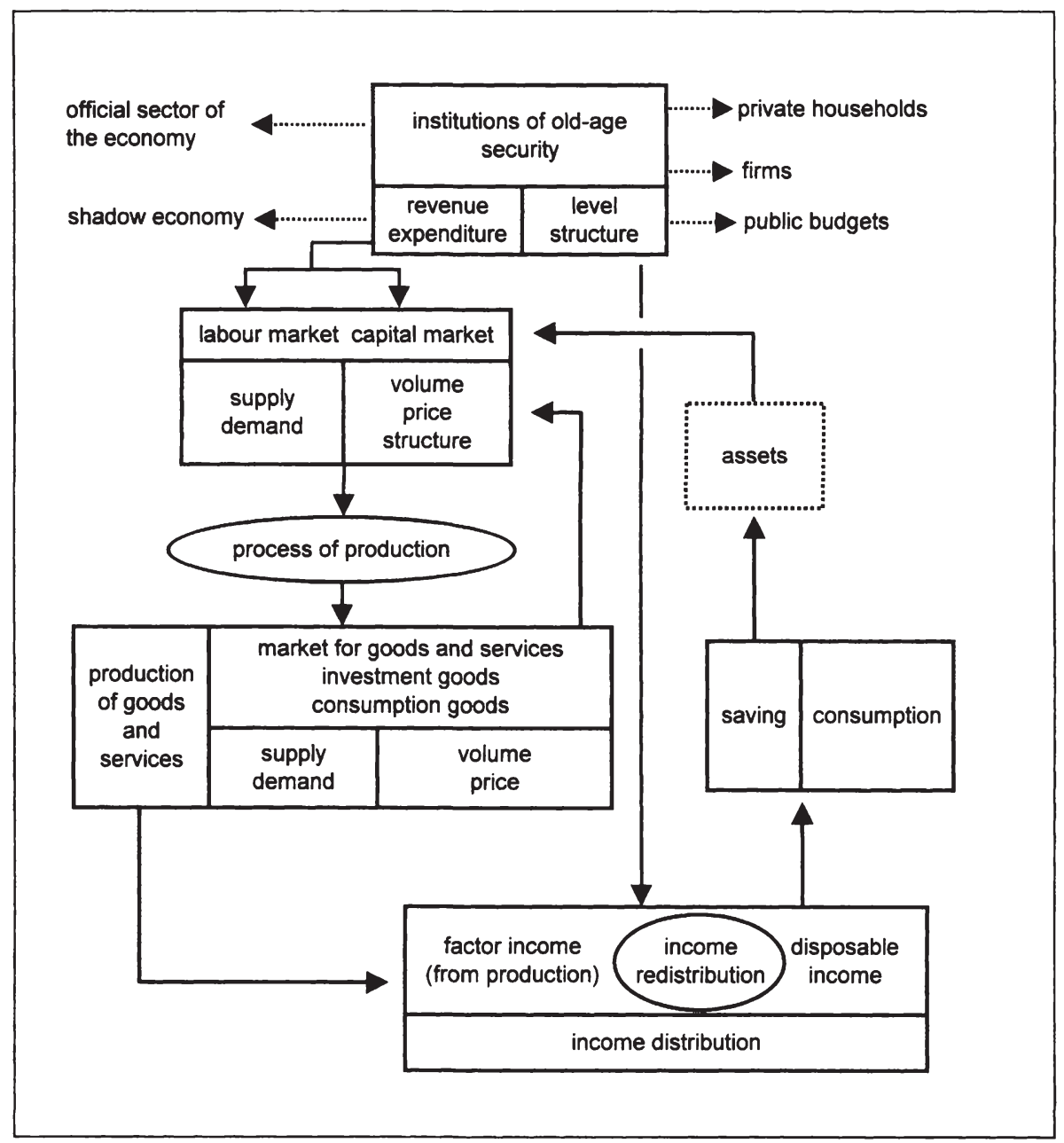

As already mentioned in the previous paragraph, economic conditions and economic development are affecting pension schemes, while volume, structure and development of pension benefits and pension financing affects the economy. Therefore, the complex interaction of pension schemes and economic (as well as demographic) are for example a challenge for preparing political decisions in pension policy. 


\section{Basic options for designing pension schemes}

There exists a great variety of pension schemes. Their construction is based on several important elements. Such elements can be used for characterising schemes, for illustrating a country's structure of public and private old-age protection arrangements as well as for outlining basic options in (re)designing pension schemes. Although country-specific conditions constrain in reality the number of relevant alternatives - at least for well-functioning schemes - there always exists not only one solution. Especially the role of the state as provider and regulator of pensions became a central topic. ${ }^{1}$ This was intensified after the collapse of centrally-planned socialist countries. But these discussions are not at all new. All major topics linked to the design of old-age protection were discussed - with different emphasis - since the „founding period“ of public social security at the end of the 19th and the beginning of the 20th century. Fundamental discussions mostly came up in periods of major structural changes in economy, demography and society. This often changed also the ideas about the adequate role of the state.

In this section main options for designing old-age protection briefly are illustrated, starting with the following elements that refer mainly to the concept of old-age security in a country:

- the role of the state as provider and/or regulator and the role of the private sector in providing pension benefits;

- mandatory and voluntary pension provision;

- coverage;

- different „pillars“ or „tiers“ of old-age protection;

- distributional objectives for the pension system in general respectively for different „tiers" of old-age protection arrangements.

\subsection{The role of the state in pension policy and the type of public activities}

As already mentioned, one of the most important topics in the design of old-age protection in a country is the role of the state and the type of public activities. This means how and to what extent the state is involved in old-age protection. Public activities that directly affect public budgets can be the financing and provision of pension benefits, the administration of a (public) pension scheme. However, if pension financing is by public authorities (e.g. by means of social insurance contributions), the provision of pension benefits not necessarily must be public, too. For example, part of compulsory contributions can be managed

1 The 1997 World Development Report of the World Bank (1997) addressed the role of the state in a changing world; see also Spulber (1997). 
by private firms and invested in the capital market. This was decided in the late nineties in Sweden, Poland and Hungary; see Table 4.

Table 4: Public and private financing and provision of pensions

\begin{tabular}{|c|c|l|}
\hline Provision & \multicolumn{1}{|c|}{ public } & \multicolumn{1}{|c|}{ private } \\
\hline public & social insurance & $\begin{array}{l}\text { voluntary contribution to } \\
\text { social insurance }\end{array}$ \\
\hline private & $\begin{array}{l}\text { mandatory contribution to } \\
\text { social insurance, but privately } \\
\text { managed funds and benefit } \\
\text { calculation }\end{array}$ & $\begin{array}{l}\text { private saving } \\
\text { firm-based (occupational) } \\
\text { pensions }\end{array}$ \\
\hline
\end{tabular}

Other public activities are (monetary) incentives to stimulate saving for old age, especially by taxation or by transfer payments. An important question in general is, how social insurance contributions, premiums (to life insurance), different types of saving, interest payments, assets (in funded schemes) and pension benefits or lump-sum payments are taxed.

The above mentioned activities affect the public budget. Other activities are without such an effect, namely regulating old-age protection administered by private actors, above all by firms as firm-based, i.e. occupational pension schemes or by insurance companies and/or by banks offering products for oldage protection.

In many countries there is at least a debate on changing public activities so that the state becomes less a provider of pensions but more a regulator. It is obvious that this for example is taking place in former socialist countries. Also Chile illustrates such a shift after introducing mandatory private old-age protection. Here the state has an important role as regulator, but also has the responsibility in giving some guarantees.

It is linked to the question of responsibility of the state for old-age protection whether (special types) of old-age provision for old-age are mandatory or voluntary and if there is mandating, how much provision (in absolute or relative terms, e.g. as percentage of wages) is required. This is also linked to distributional questions which will be discussed below.

It was already mentioned, that financing and provision of benefits not necessarily both have to be administered either by public or private organisations. There is also no simple link of mandatory arrangements to public administration or of voluntary arrangements to private providers. This is illustrated in Table 5. Mandatory schemes - even if they are the major part of pension provision - must not necessarily be public as the examples Chile and 
Kazakhstan show. But in most countries at least the basic mandatory element of pension provision is administered by public authorities.

Table 5: Public and private management of mandatory and voluntary pension schemes

\begin{tabular}{|c|c|c|}
\hline & public & private \\
\hline mandatory & social insurance & $\begin{array}{c}\text { mandatory private scheme } \\
\text { (e.g. Chile) }\end{array}$ \\
\hline voluntary & $\begin{array}{c}\text { voluntary contribution to } \\
\text { social insurance }\end{array}$ & $\begin{array}{c}\text { private life insurance, } \\
\text { private saving }\end{array}$ \\
\hline
\end{tabular}

Public pension schemes can be

- a part of the general state budget,

- a part of a unified social insurance budget which covers e.g. also health insurance, or can have

- a specific separate budget.

\subsection{Coverage by uniform or sector-specific schemes and linked to specific activities}

If there is a mandatory (for example public) pension scheme, it is important whether it covers the whole population or whether different schemes for different groups of the population exist - for example for farmers, employees in mining industry, self-employed, employees of the public sector (or even - as in Germany - for civil servants). In many countries formal pension schemes were at first introduced for employees of the public sector. Public administration sometimes was the core element of the formal economy while a major part of economic activities was informal.

If for example the building of formal pension schemes started in the public sector, it is important whether it is designed in such a way that in principle it can be extended to other groups of the population (e.g. other groups of employees) or whether it is very specifically tailored for employees in public administration.

If there are such sector-specific schemes, several problems may emerge. Only three of them will be mentioned here:

Mobility between sectors or occupations may be hindered. At least specific coordination rules are necessary. 
If the generosity of the schemes is different - e.g. higher in the public sector -, if there exist privileges (for example for military, politicians), sooner or later debates about justice and equal treatment will come up.

If there are structural changes between sectors or branches this may cause financing problems, at least in pay-as-you-go financed schemes (where current revenue is used to finance current expenditure). For example in Germany sector-specific schemes for farmers and for the mining industry exist. These are two sectors with a radical reduction in employment during post-war years. The number of contributors compared to present and future beneficiaries declined, the pensioner ratio increased. If an increase in the sector-specific contribution rate or a reduction in the pension level - for economic or political reasons - is not acceptable, then at least two options exist:

a) Fiscal equalisation measures between several pension schemes. Then the contribution rates in other sectors are higher than necessary in these schemes to balance the budget in order to transfer some money to finance the deficit in the pension scheme of the shrinking sector.

b) To subsidise the pension scheme from general tax revenue.

Another aspect of coverage is linked to the question, what are the characteristics or activities of persons included in a scheme. This is very often depending on the definition of "work“. This definition, what kind of work is relevant to be covered by a scheme, has to be decided. This is illustrated by Figure 6, based on rules in Germany (for coverage in social insurance).

Is coverage linked only to gainful employment? ${ }^{1}$ Is it also self-employment? The borderline of employees and self-employed is changing over time. New legal forms of economic activity for example in the process of outsourcing activities from (big) companies make such a distinction problematic. In principle employees and self-employed should be covered mandatorily. ${ }^{2}$ One argument for outsourcing some activities is to reduce non-wage labour costs (employer's contribution to social insurance in case of having employees), if the outsourced persons are not covered mandatorily.

Another question is, whether other types of work, like caring for children or elderly people, should also be the basis for coverage.

1 There may be also some limitations even in case of types of work which are in principle covered, like a floor or a ceiling of earnings for mandatory coverage.

2 In Germany some groups of self-employed are mandatorily covered by social insurance, while for some other groups (e.g. lawyers, architects) special schemes exist. But there are other groups without mandatory coverage. This may cause problems of inadequate pension provision when these people get old. 


\section{Figure 6: Types of work and coverage by social insurance}

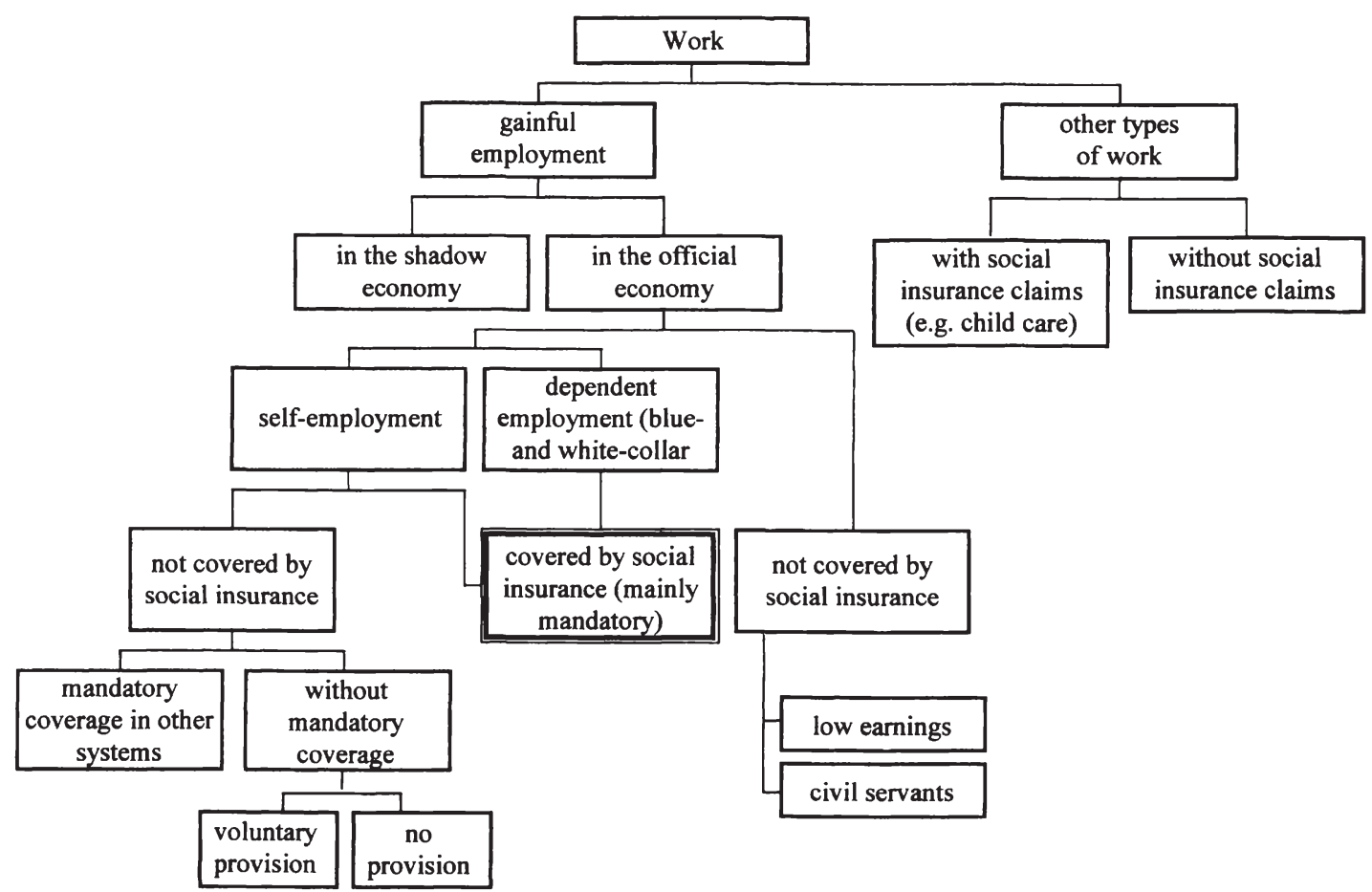


In many (especially developing) countries a major part of the people in "working age" are self-employed. Often it is difficult to decide, whether this is formal (official) or informal economic activity (in the "shadow economy"). To extend coverage is a big problem in many countries.

\subsection{Different „tiers“ or „pillars“ of pension provision}

If we look at industrialised market economies, we find different (formal) pension arrangements. This mostly is labelled as a "multi-pillar" structure. It is very common to use the concept of three "pillars" of old-age security. In my view it is more adequate to use the term "tier" instead of „pillar". ${ }^{1}$ It illustrates better that (in many countries) different schemes build upon each other as

- a basic 1st tier,

- a supplementary 2 nd tier and

- an additional 3rd tier.

In market economies this multi-tier structure of public/ private, mandatory/ voluntary schemes exists in quite different combinations. Socialist economies had in principle public mandatory schemes, sometimes in addition public voluntary possibilities for saving, but formal private pension schemes were rare.

It is not questioned that some kind of mandatory scheme should exist as a basis for old-age security, equal for the whole population or for specific groups of the population. In general this is a public scheme. The exemption are mandatory private schemes as the base for old-age protection like in Chile or Kazakhstan.

Concerning mandatory (especially) public schemes (1st tier) different distributional objectives are relevant for structuring pension financing and pension provision.

In basic pension schemes we can distinguish as major alternatives concerning income distribution

- the type of income redistribution aimed at and

- the dominant distributional objective.

1 See for example also the picture of a "three-legged stool“ (Cutler 1996). - The term "pillar" stimulates the association of a construction, a building, based on three columns of more or less equal size, i.e. of equal „importance“ for old-age security. In reality this is not an adequate picture in many countries, because the size of the three elements most often is quite different (a building would look really curious if it was based on these pillars ). The term „tier" (or layer) instead of pillar is not only more neutral, but illustrates much better reality if e.g. supplementary firm-based (occupational) or additional private life-insurance pensions are build upon the first „tier“ (while a stool or a building needs „pillars“ or legs standing apart and not one upon the other). 
A major international debate on the appropriate role of the publicly managed first tier is whether this should aim at interpersonal redistribution or at intertemporal income transfer over the life cycle, i.e. from the working period to the period after retiring from work. ${ }^{1}$ For some countries - like former socialist countries - this is a new option because their pension schemes were dominated by the aim to redistribute personal income and to link pensions only marginally to former contributions or former earnings. ${ }^{2}$

Concerning the key distributional objective we can distinguish between

- avoiding poverty in old age (minimum protection) by mostly flat-rate or income- or asset-tested pension schemes, and

- income-related schemes aiming at income and consumption smoothing over the life cycle, i.e. linking pensions in some way to former income (mostly earnings).

Of course, these two approaches can also be combined in one scheme.

Income- (earnings)-related pension schemes can be designed in different ways. One aspect is whether they are

- defined benefit schemes (defining e.g. a replacement rate) or

- defined contribution schemes (linking benefits to former absolute amount of contribution payments and on some additional ,interest"). ${ }^{3}$

In a simple manner the difference between defined benefit and defined contribution schemes can be explained as follows: In a defined benefit scheme there is e.g. a target value of a pension level or replacement rate depending for example on the number of years of insurance, the (relative, absolute) amount of income etc. Insured persons know, if they have a specific number of pension claims, the outcome (benefit) of the scheme will be defined. ${ }^{4}$ In a defined

However, there can be mixed systems.

2 There is, for example, a clear answer from the mainstream World Bank proposals: to concentrate interpersonal redistribution within the first tier and leave intertemporal redistribution to the second tier, that should be mandatory, privately managed and capital funded; see World Bank (1994). - The World Bank Report uses the „multi-pillar“ concept in a normative sense: The different „pillars“ are linked to specific goals and responsibilities of actors. The World Bank Report (1994) is pointing out clearly, that the aim of the first pillar is to avoid poverty (by interpersonal redistribution), while the second and third pillar should contribute to an additional income-related protection. I use the multi-tier approach in its descriptive, positive sense, because for example for the first tier different objectives can be relevant.

3 For a comparison of real and supposed differences see Cichon (1999).

4 For example in German statutory pension insurance a certain number of „earnings points“ is linked to a certain percentage of net average earnings of those who are employed (i.e. the rule created by the „1992 Pension Reform“. For more details - also on the German pension schemes - see Schmähl (1993) and (1999a). 
contribution scheme - which is now introduced as first tier in Sweden and even before in Latvia $^{1}$ - the accumulated sum of (absolute) contribution payments (including some ,interest") is divided by remaining life expectancy at the year of retirement, i.e. calculating an annuity. The amount of benefit to be expected or the extent of the replacement rate (of former income) is not decided upon in advance, but can only be seen when the pension benefit is calculated for the first time. This is also the case in the new Chilean private mandatory pension scheme. $^{2}$

In defined benefit schemes the contribution-benefit link can be of different strength, resulting from the mix of different objectives. The link is closest, if intertemporal redistribution dominates. In market economies we can find a trend towards a closer contribution-benefit link in defined benefit schemes (resulting from different types of measures). An additional way to realise this is the establishment of a defined contribution scheme.

Figure 7 illustrates these different approaches in designing the first (mandatory and public) tier by combining the two different types of objectives as well as of redistributing income (over the life cycle).

\section{Figure 7: Mandatory public pension schemes - first tier -}

\begin{tabular}{|l|l|l|}
\hline \multicolumn{1}{|c|}{$\begin{array}{r}\text { type of } \\
\text { redistribution }\end{array}$} & interpersonal redistribution & intertemporal redistribution \\
\hline abjective & $\begin{array}{l}\text { flat-rate pension } \\
\text { means- or income tested } \\
\text { transfer payments }\end{array}$ & $\begin{array}{l}\text { minimum pension based on } \\
\text { contribution payments }\end{array}$ \\
\hline $\begin{array}{l}\text { income-related } \\
\text { (income and consumption } \\
\text { smoothing) }\end{array}$ & $\begin{array}{l}\text { social insurance based on } \\
\text { weak contribution-benefit } \\
\text { link }\end{array}$ & $\begin{array}{l}\text { social insurance with strong } \\
\text { contribution-benefit link }\end{array}$ \\
\hline
\end{tabular}

1 In Latvia the already existing - but not implemented - plans of the Swedish pension reform (see Palmer 1999) became relevant via World Bank missions (including people from Sweden). This approach now also became relevant in Poland and - in part - in Hungary. For more details see Schmähl (1999b).

2 Defined contribution schemes can be either pay-as-you-go financed (like in Sweden and Latvia) or funded (like in Chile). The two types of pension schemes have been well-known in supplementary occupational (firm-based) pension schemes since a long time. But a defined contribution scheme as mandatory first tier (and also pay-as-you-go financed) is a new development. The World Bank has labelled this approach as „notional defined contribution scheme". 
It becomes especially obvious in schemes aimed mainly at intertemporal redistribution, that the design of the financing instruments and that of benefits (initial calculation and indexation, pension adjustment) cannot be decided independently. But the general level of pensions (e.g. pension benefits in relation to earnings of employees as an indicator for income distribution between "generations") can be quite different as well as the so-called "replacement rate" (mostly defined as individual pension benefit as ratio of former income or earnings of the pensioner at time of retirement).

The calculation of the initial benefit in earnings-related defined benefit schemes can take into account earnings of different periods of the working period, for example some last or best years up to all years of the working career. The closer the contribution-benefit relationship is aimed at, the more it is necessary to take into account all working years for pension calculation. ${ }^{1}$ In several countries there is a tendency to extend the period of earnings (contribution payments) relevant for pension calculation, see for example Austria and now also Sweden, which extended the calculation to the whole number of years of contribution, an approach which since a long time has been realised in Germany.

Another important aspect for income of pensioners is the adjustment (indexation) of pensions. When life expectancy is increasing, pension adjustment becomes more and more important. Different objectives are relevant here: to stabilise the purchasing power of the pension by price indexation of pensions or - as it is necessary in an income-related pension scheme - to adjust pensions according to an income (or earnings) index, which can be defined in different ways (e.g. by using gross or net average earnings).

Instruments of financing mainly are social insurance contributions and taxes. Contributions are the adequate instrument for acquiring pension claims, while paying taxes does not create a specific claim. Contributions and taxes can have different assessment bases, different floors and/or ceilings and their scale of tariff can have different structure. Contribution rates may be split between a contribution of the employer (the firm) and a contribution of the employee. ${ }^{2}$ In socialist countries (but also in Sweden) contributions were mostly firms ${ }^{6}$ contributions. In order to improve contribution collection many countries try to give individuals a higher incentive to contribute by introducing individual

1 In former socialist countries such individual insurance records were not used in general and have to be built up step by step, if schemes shall be implemented that calculate pensions on information of individual earnings of longer periods or the whole working life. The link to the aspect of administrative capacity is obvious. - For initial pension calculation also eligibility criteria are decisive, like waiting periods, retirement ages, criteria for disability etc.

2 For more details Schmähl (1994) and (2000a). 
accounts as well as by increasing (step by step) the employees" part of the contribution payment. ${ }^{1}$

The method of financing - pay-as-you-go versus funding - will be discussed in the final section of this paper. It is relevant not only for the first tier, but also for supplementary schemes.

Concerning supplementary pensions (second tier), an important topic is whether they shall be also mandatory or voluntary. Looking at the development in market economies there is a tendency that in countries with a low level of mandatory public schemes (first tier) or with schemes mostly aimed at avoiding poverty in old age, the second supplementary tier is also mandatory, while in countries with more elaborated income-related public pension schemes the supplementary schemes are voluntary. ${ }^{2}$

In general supplementary schemes are capital funded. The decisions on design and especially the volume of the first tier is a decisive factor for structure and volume of the second as well as third tier. ${ }^{3}$

Figure 8 outlines major options for designing formal pension arrangements which have to be decided.

\section{Financing methods - Pay-as-you-go and Funding}

Of great importance in the debate on designing and reforming pension schemes is the method of financing - pay-as-you-go (PAYG) or capital (pre-)funding -, which is closely linked in reality to the management of the pension scheme, public or private. There has been an academic as well as political debate on financing methods and their effects as long as social insurance schemes have been existing. If we take a look at economic (academic) journals one gets the impression that PAYG versus funding is the most important aspect in pension reform. There is a strong pressure by many actors towards more funding. However, there are other important topics in pension reform, especially in redesigning PAYG schemes.

1 A reduction in employer's contributions as well as in earnings-based contribution payments in general often is favoured in political debates to improve international economic competitiveness. This is discussed in Schmähl (1995).

2 For a typology of countries illustrating this see Schmähl (1991): 47-50.

3 In addition for second and especially third tier arrangements it is important whether they include risk pooling (insurance schemes) or whether they are pure saving schemes. 
Figure 8: Some major choices in designing different tiers of pension schemes

\begin{tabular}{|l|l|}
\hline 1st tier & $\begin{array}{l}\text { mandatory, PAYG } \\
\text { public or private } \\
\text { major goal: } \\
\text { avoiding poverty in old age } \\
\text { income related pension } \\
\text { - defined benefit } \\
\text { - defined contribution } \\
\text { type of redistribution: } \\
\text { interpersonal } \\
\text { intertemporal } \\
\text { (close contribution-benefit link) }\end{array}$ \\
\hline 2nd tier & $\begin{array}{l}\text { mandatory or voluntary } \\
\text { funded or PAYG } \\
\text { public or privately managed } \\
\text { linked to employment or company } \\
\text { defined benefit or defined contribution }\end{array}$ \\
\hline 3rd tier & $\begin{array}{l}\text { voluntary, privately managed, funded } \\
\text { defined contribution }\end{array}$ \\
\hline
\end{tabular}

\subsection{PAYG schemes - basic elements of financial conditions}

In the beginning some basic conditions in a PAYG scheme are outlined when dealing with financial imbalance (for example in case of an ageing population). Neglecting a buffer stock to deal with seasonal fluctuations in revenue and expenditure, a PAYG scheme is characterised in a single period (one year) by a simple budget equation, when current expenditure (here only pension benefits, $\mathrm{P})^{1}$ have to be financed by current revenue. ${ }^{2}$ Current revenue are from

1 Often also expenditure in case of rehabilitation measures (to prevent disability or early retirement pensions) are included in such a scheme. The following presentation is as simple as possible and therefore limited to some very basic aspects only.

2 All variables used in the following equations are for the same year. Therefore, a time index is neglected. 
contribution payments $(\mathrm{C})$ (based on earnings $=$ wages and salaries) and from the state budget $(\mathrm{FG}=$ Federal Grant):
(1) $\mathrm{C}+\mathrm{FG}=\mathrm{P}$

Contribution Revenue (C) is based on the contribution rate (c) and the sum of contributory earnings. This can be split into the number of contributors (NC) and the average (contributory) gross earnings $(\mathrm{AW})^{1}$ :

(2) $\mathrm{C}=\mathrm{c} \cdot \mathrm{NC} \cdot \mathrm{AW}$

The pension expenditure can be split into the number of pensioners (NP) and the average amount of pensions (AP):

(3) $\mathrm{P}=\mathrm{NP} \cdot \mathrm{AP}$

Then the budget equation can be written as:

$$
c \cdot N C \cdot A W+F G=N P \cdot A P
$$

The contribution rate (c) that is necessary to balance the budget of the pension scheme is:

$$
\mathrm{c}=\frac{\mathrm{NP}}{\mathrm{NC}} \cdot \frac{\mathrm{AP}}{\mathrm{AW}}-\mathrm{FG}
$$

The first ratio is the pensioner ratio (PR), the second the (average gross) pension level (APL):

\section{(6) $\quad c=P R \cdot A P L-F G$}

If the revenue from the state budget ${ }^{2}$ is zero, the contribution rate necessary to balance the budget depends on the development of the pensioner ratio as well as the pension level.

The following diagram (Figure 9) illustrates the interaction of these variables. An existing budget constraint (the indifference curve, based on a contribution rate and a sum of federal grant) can be sufficient to finance several combinations of pensioner ratio and pension level.

1 There may be a floor and/or a ceiling for earnings which are relevant for contribution payments.

2 The reason for such payments from the state budget - especially when the pension scheme shall have a close contribution-benefit link - is often to cover expenditure which are targeted to redistribute income towards families, persons with low earnings etc. 
Figure 9: Budget constraint and alternative pensioner ratios and pension levels

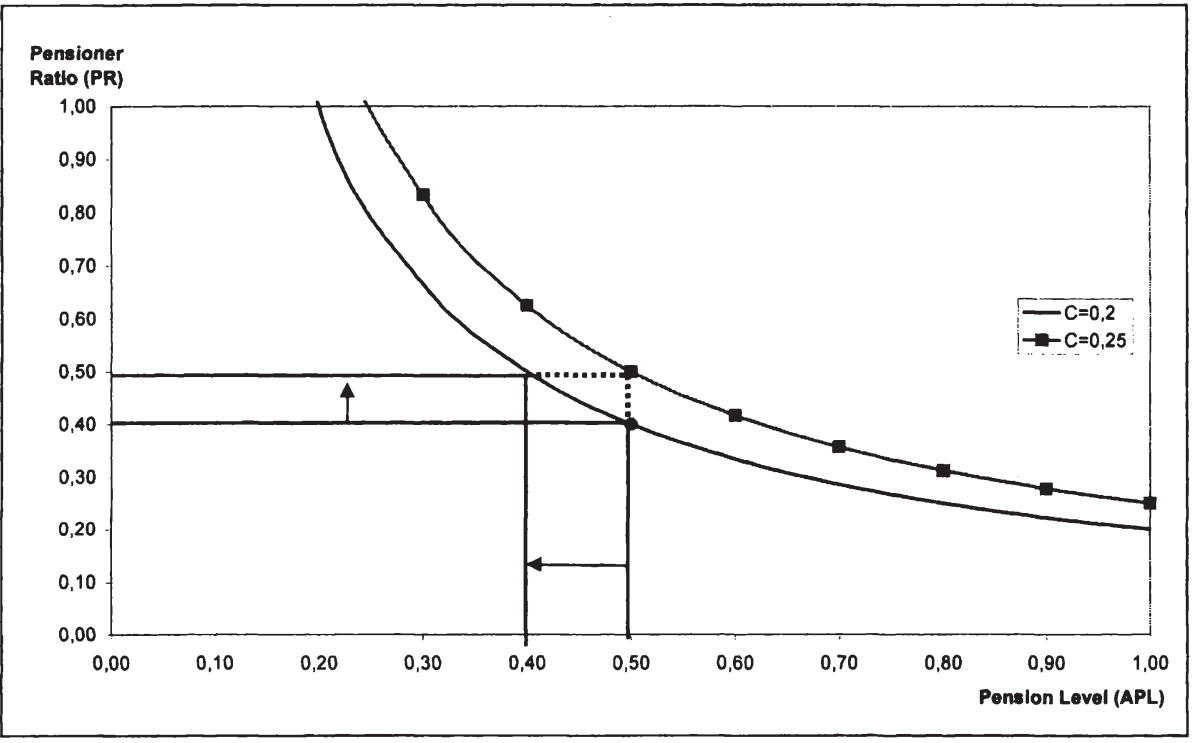

By this simple diagram the basic financing problem is illustrated. It is obvious, if for example in the process of population aging PR will increase (e.g. from 0.4 to 0.5 ), and the budget constraint is fixed, then APL has to be reduced. In reality several basic options exist: One is the reduction in the pension level already mentioned. Another is to change the budget constraint, either by increasing the contribution rate ${ }^{1}$ (in Figure 9 from $20 \%$ to $25 \%$ ) and/or the revenue from the state budget. But there exist also possibilities to influence the pensioner ratio, especially by changing retirement ages.

\subsection{Financing methods in micro-macro perspective as well as cross- sectional and longitudinal perspective}

When dealing with pension policy and especially the different financing methods, there are macro- and microeconomic aspects to consider. Mostly a cross-sectional view is applied, taking into consideration conditions and decisions in one year. There is, however, another perspective, which is important from the individual's point of view, namely a longitudinal perspective. This can be illustrated using the following diagram (Figure 10).

1 A more detailed analysis would show that more alternatives exist, e.g. broadening the base for contribution payments. 
Figure 10: Old-age Security: Cross-sectional and longitudinal perspective

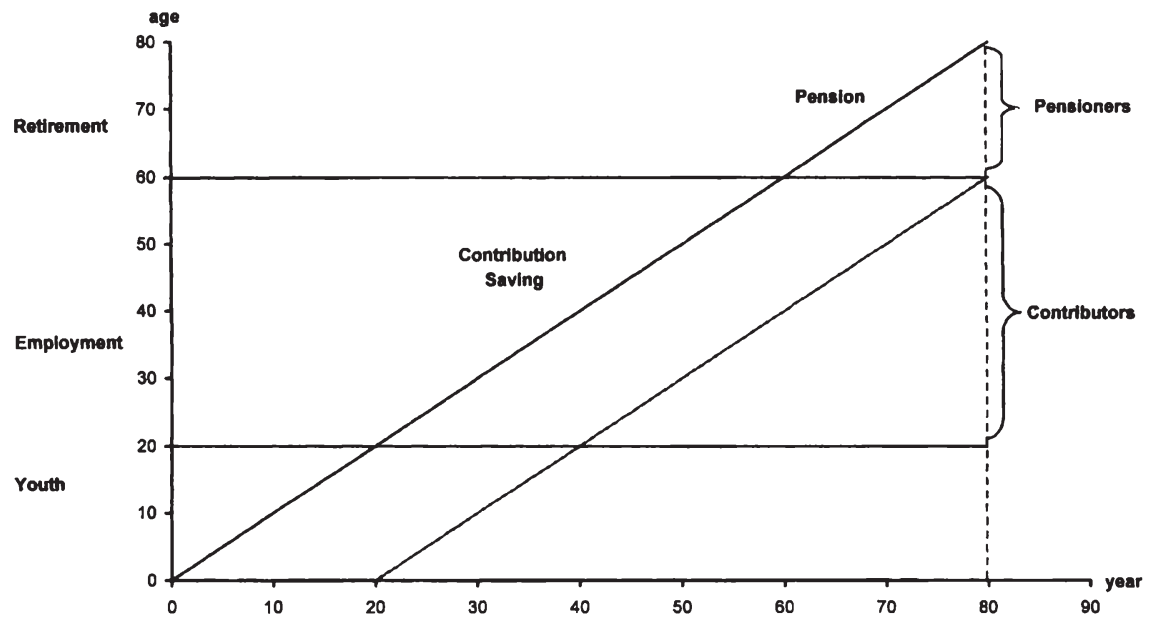

In Figure 10 on one axis there is the historical time (calendar year), on the other the biological time (age). When talking about pension policy, the cross-sectional view is often dominating: There are contributors (in one year), there are beneficiaries (pensioners) (e.g. in year $\mathrm{t}_{80}$ ). In a PAYG scheme contributions are used to finance pension expenditure of the same year.

From a longitudinal perspective - independent of the financing method (!) - for the individual contributor his/her contribution payments during the working life is a kind of provision (saving) for one's own old age (or for his/her spouse) (e.g. for persons born in $t_{0}$ contribution payments are from $t_{20}$ up to retirement age $\left.t_{60}\right)$. This becomes especially clear if there is a close contribution-benefit link in a PAYG scheme. Provision for old age therefore not only takes place in a funded scheme, when during working life saving is accumulated as a means for pension payments after retiring from working life, but also in PAYG schemes with a link of benefits to (former) contribution payments.

We can see, that the longitudinal view on provision for old age and the microperspective are not linked to the financing method which mainly is a macrophenomenon, whether in a pension scheme in the beginning a fund is accumulated or not. Even if there is an accumulation of money in the initial phase of a funded scheme, in later years there can also be a balance of contribution revenue and pension expenditure. 


\subsection{Comparing PAYG and funded schemes}

There was an intense debate on the adequacy of PAYG and funding already in the late 19th century. This has been a major topic up to today. It is obvious that in a private scheme without mandatory membership, the scheme has to accumulate a "stock of capital" in the beginning in case that in later years the number of contributors declines or nobody enters this scheme anymore. Therefore, funding is necessary from the point of view of securing the accumulated pension claims. In a scheme with mandatory coverage this more technical reason is not of great importance. Nevertheless, one has to ask, which financing method is adequate especially in the light of its economic effects.

It is not possible to deal here with these complex problems. Only a few aspects can be mentioned. One question is, when do we compare different pension schemes based on different financing methods. It was already mentioned that in the starting period of a funded scheme contributions (premiums) are collected but no pensions are paid. Only after decades pension payments start for those who have joined the scheme decades ago. On the other hand, in a PAYG scheme pension payments can start immediately when contribution collection starts.

Therefore, it can be no surprise that a funded scheme has ,a fund" at least from the starting period. ${ }^{1}$ But is this fund necessarily, as often mentioned, a mechanism to increase individual as well as national saving (which then is the base for financing investment and can increase GDP or the economic growth rate)?

When a funded scheme starts, what was the type and method of old-age security before? No formal pension scheme may have existed. But nevertheless, old people existed and their consumption had to be "financed“, for example by intrafamiliar transfers, an intrafamiliar PAYG scheme. Now the funded scheme is introduced and the working part of the population has to pay contributions to this scheme. But also the consumption of already old people has still to be financed. Therefore, the financial „burden“ of the working part of the population increases. What will be the reaction concerning consumption and saving? There may be a reduction of saving, a substitution process: Savings are accumulated in the new funded scheme, but other savings are reduced. The macroeconomic effect is not clear.

Although theoretical models are constructed to show clearly that a funded scheme increases (national) saving, the empirical evidence is far from conclusive. ${ }^{2}$ In reality there is no such elegant and "well-oiled“ mechanism as in

1 This is in the first instance financial capital and should not be looked upon as identical to real capital formation. Whether this results from accumulating financial capital in a capital funded pension scheme is a different question.

2 The debate on this topic is often biased; this is discussed in Schmähl (2000b), with further references. See also Aaron and Reischauer (1998), Thompson (1998). Publications on financing methods can fill libraries. 
neo-classical text books. The impact of different financing methods will in reality depend to a great extent on country-specific conditions.

The following diagram is no test of theoretical models, but the data cast some doubts on the link between financing method and national saving (Figure 11).

\section{Figure 11}

Private Pension Assets in \% of

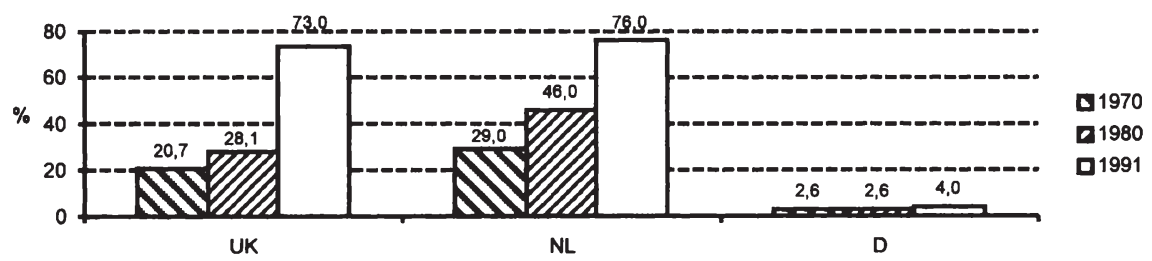

Gross National Savings in \%

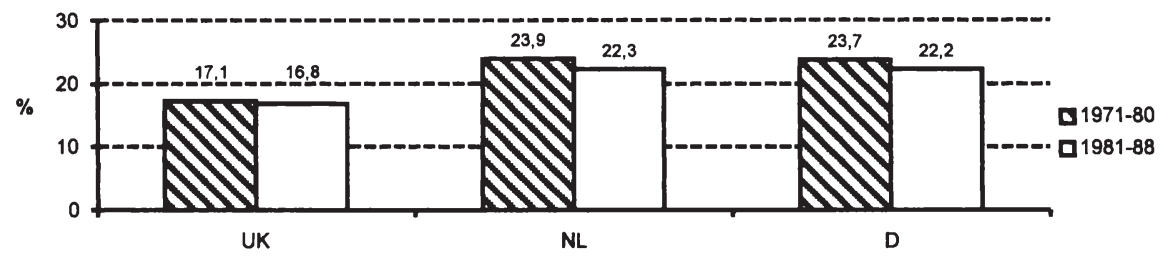

Source: Data taken from Thompson

In Figure 11 three countries with different structure of their pension arrangements concerning financing methods are compared, the Netherlands, the United Kingdom and Germany. The first two countries have (as ratio of their national product) much more funded pensions than Germany. And the relative amount of funded pensions increased considerably during the last years. But this is mirrored neither in the national saving rate nor in the development of the national saving rate.

Obviously one has to be very cautious in making firm conclusions as, however, this often is the case in the academic as well as political debate. There are also many actors in financial markets who have a commercial interest to get an important part of ,,pension money“ into capital funded schemes.

It is not questioned here that in principle a mix of different financing methods can be positive - for the individual as well as for the economy - because PAYG and funding is confronted with different types of risks (at least to a different 
extent). ${ }^{1}$ The adequate mix, however, very much depends on the countryspecific conditions. The macro-economic impact of a world-wide growth of funded pension schemes and investment activities of pension fund managers for example for financial markets, especially in small countries - is up to now far from being adequately analysed.

It would be, however, a wrong perspective on pension policy, to focus only or mainly on the funding issue, the increase of capital funding. There exist important tasks also in PAYG schemes in adapting and redesigning them according to changing economic, demographic and political conditions. This has to be done in a manner that the economic ${ }^{2}$ and social effects are in line with the dominating goals in the society.

Pension schemes should, however, first of all be an instrument for social security in old age and not directly or even mainly be an instrument of economic policy - for labour market policy (to reduce unemployment by early retirement), development of financial markets etc. There are good reasons that a ,division of labour" is also useful in distributing tasks to different institutions. Pension schemes - especially public schemes - should not be overburdened by too many different tasks. This reduces transparency, may increase resistance in an area where long-term decisions have to be taken and where a "feeling of security" for the individual should also be one effect of pension schemes.

An evaluation of risks linked to privatising social security is given in Panel (1999).

2 For example to reduce negative incentive effects e.g. on labour demand and labour supply. 


\section{References}

AARON, H. J. / REISCHAUER, R.B. (1998)

Countdown to Reform - The Great Social Security Debate, New York (The Century Foundation Press).

CICHON, M. (1999)

Notional defined-contribution schemes. Old wine in new bottles?, in: International Social Security Review, Vol. 52, pp. 87-105.

ENQUETE-KOMMISSION “DEMOGRAPHISCHER WANDEL” (1998)

Zweiter Zwischenbericht, Bundestags-Drucksache 13/11460, Bonn.

JACOBS, K. / SCHMÄHL, W. (1989)

The Process of Retirement in Germany: Trends, Public Discussion and Options for its Redefinition, in: W. Schmähl (Ed.), Redefining the Process of Retirement, Berlin, Heidelberg, pp. 13-38.

KAA, D. J. van de

Europe and its Population: The Long View, in: Dirk van de Kaa et al. (Eds.), European Populations - Unity in Diversity -, Dordrecht, Boston, London (Kluwer) 1999, pp. 1-49.

MANTON, K. G. / STALLARD, E. / CORDER, L. (1997)

Changes in the Age Dependency of Mortality and Disability, in: Demography, Vol. 34, pp. 135-157.

MARKIDES, K. S. (1993)

Trends in the Health of the Elderly in Western Societies, in: A. B. Atkinson, M. Rein (Eds.), Age, Work and Social Security, New York, pp. 3-16.

PALMER, E. (1999)

The Swedish Pension Reform Model - Framework and Issues, mimeo.

PANEL ON PRIVATIZATION OF SOCIAL SECURITY (1999)

Executive Summary, in: Social Security Bulletin, Vol. 62, pp. 65-74.

SCHMÄHL, W. (1991)

On the Future Development of Retirement in Europe especially of Supplementary Pension Schemes, in: W. Schmähl (Ed.), The Future of Basic and Supplementary Pension Schemes in the European Community - 1992 and beyond, Baden-Baden (Nomos), pp.31-70.

SCHMÄHL, W. (1993)

The 1992 Reform of Public Pensions in Germany, in: Journal of European Social Policy, Vol. 3, pp. 39-51.

SCHMÄHL, W. (1994)

Fundamental Issues of Financing of Social Security with Respect to the Transformation of former Socialist Economies, in: B. v. Maydell, E.-M. 
Hohnerlein (Eds.), The Transformation of Social Security Systems in Central and Eastern Europe, Leuven, pp. 285-325.

SCHMÄHL, W. (1995a)

Social Security and Competitiveness, in: International Social Security Association (Ed.), Social Security Tomorrow (Studies and Research No. 36), Geneva, pp. 19-28.

SCHMÄHL, W. (1995b)

Migration und soziale Sicherung, in: Hamburger Jahrbuch für Wirtschafts- und Gesellschaftspolitik, 40. Jahr; pp. 247-271.

SCHMÄHL, W. (1999a)

Pension Reforms in Germany: Major Topics, Decisions and Developments, in: K. Müller, A. Ryll, H.-J. Wagener (Eds.), Transformation of Social Security: Pensions in Central-Eastern Europe, Heidelberg (Physica), pp. 91-120.

SCHMÄHL, W. (1999b)

Pension systems, in: Consensus (Ed.), Change and Choice in Social Protection: The Experience of Central and Eastern Europe, Volume 1, Bruxelles, pp. 27-65.

SCHMÄHL, W. (2000a)

Contributions and Taxes for Financing Public Pension Expenditure: Looking for an adequate structure of finance, in: G. Hughes, J. Stewart (Eds.), Dordrecht ,Boston, London (Kluwer).

SCHMÄHL, W. (2000b)

Pay-as-you-go versus capital funding: Towards a more balanced view in pension policy, in: G. Hughes, J. Stewart (Eds.), Dordrecht ,Boston, London (Kluwer).

SPULBER, Nicolas (1997)

Redefining the state - Privatization and Welfare Reform in Industrial and Transitional Economies, Cambridge (Cambridge University Press).

THOMPSON, L. (1998)

Older and Wiser: The Economics of Public Pensions, Washington, D.C. (Urban).

WORLD BANK (1994)

Averting the Old-Age Crisis, Oxford (Oxford University Press).

WORLD BANK (1997)

World Development Report 1997, New York (Oxford University Press). 


\section{„Social Justice” in a Market Economy}

- Some Results of the Discussion -

\section{Hermann Sautter}

During the Summer School many issues had been discussed, different perspectives of the reasoning had been chosen and various experiences had been presented. The common question was: How can the market system with its inherent inequalities be made compatible with a political system promising the equality of rights? The general answer was: By an institutional framework which promotes private initiative in the market, which covers social risks and moderates economic inequalities. These institutions have to be established by the state, or more precisely: by a strong state which does exactly this job and avoids interfering in the market process. A general result of the discussion, which shall be listed here as the first point, therefore was:

\section{1) In order to implement , social justice" in a market economy we need a strong but limited state.}

It is true that many institutions are the outcome of private initiatives. But the decisive ones have to be established by political actions. As to the markets, the state has primarily to establish reliable property rights which are guaranteed by judicial sanctions. In order to fulfill this function, the state must be the owner of monopoly power within the national boundaries, and this power must be executed within the constitutional framework. One topic raised in nearly all discussions was the weakness of Latin American states in this respect. To mention just one of the numerous examples discussed: Private firms in El Salvador renounce to some lucrative export business because they do not know what happens with their merchandise on the way from factory to the harbour. The state cannot guarantee legal protection on the roads. The result is that private initiatives are impeded or even eliminated.

Property rights may be threatened by social conflicts which are the consequence of an extremely unequal distributional pattern. The concentration of landownership in many Latin American countries and the concomitant insecurity of land property rights illustrate the problem. In these cases a redistribution of assets and incomes promotes legal security. It becomes an investment in ,social capital' which has a positive rate of return; redistribution is not a waste of resources.

Referring to social insurance schemes, the state has to establish adequate institutions which cover social risks. Private insurance markets cannot cover them as these risks are „external” to the contract-parties. Mandatory insurances are an adequate institution to handle the problem. Only the state can establish 
such institutions, but one has to acknowledge that some people cannot afford to be insured. Therefore, public actions with a redistributional element are unavoidable. They are an adequate answer to the failure of private insurance markets.

In order to establish institutions of the kind mentioned, one needs political authorities which are capable of acting, in other words: which are ,strong”. This does not mean ,authoritarian”. In the short run, regimes like that may secure some stability, but in the long run the concomitant repression of selfresponsibility and individual creativity becomes an obstacle to economic development. „Strong” rather means, that the state has sufficient personal and financial resources to act within the framework of a democratic constitution.

In this respect, Latin America shows some positive developments, but much remains to be done. Democratic regimes replaced authoritarian ones, and a "democratic culture" is slowly developing. In some countries - Chile was mentioned - another positive experience is worth to be mentioned, namely improvements in the tax administration which strengthened government's capability to deliver "public goods" - and the establishment of efficient institutions is the central issue of this kind. Tax evasion was reduced by intelligent controls and the efficiency of public administration has been improved.

However, the „strong” state has to be limited in its actions. It should refrain from manipulating private activities and not intervene into the market process. Much is left to be done in this respect. There are numerous examples of unnecessary and inefficient regulations in Latin American countries. Therefore, the call for "deregulation" has its own right, but it should be supplemented by resolute efforts to strengthen the state in the fulfillment of its indispensable functions.

This point is frequently neglected in a blind textbook-oriented policy of economic reforms. Inspired by a North-American ideology of „neoliberalism”, the state very often seems to be treated as the big enemy of individual liberties without recognizing that we need a functioning state in order to guarantee these liberties. Latin America, therefore, should follow a realistic concept of economic and political reforms, which include the formation of a strong, limited state.

\section{2) There is no uniform institutional framework for implementing "social justice" in a market economy. On the contrary: The pos- sible arrangements vary to a large degree.}

The system of institutions depends on cultural tradition, on the political power structure, on one's country demographic situation, people's mentality etc. Some of the examples discussed during the Summer School are the following: In Sweden, the collective insurance systems are shaped by people's strong social 
different cultural tradition); in Germany, the social reforms in the last century reflected the political constellation during the Bismarck-era, and the concept of a „social market economy" was strongly influenced by the rejection of a totalitarian state as it was experienced under the Nazi-regime; the pension system in Singapore is based on a high propensity to save (which, of course, is strengthened by this system) and it reflects the demographic situation of this country; in Uganda, health-care systems are based on traditional social networks.

All of these institutions do have their own advantages and disadvantages. No country has an ,ideal system". Powerful nations frequently try to present their own institutions as the superior ones, but one should not confuse political power with institutional excellence.

The lesson to be drawn for Latin America is that it has to find its own solutions. In shaping their own institutions, Latin American countries can learn from many other countries, not only from one.

\section{3) In the educational system, there is scope for more competition.}

Educational efforts stimulate economic growth. Following the microeconomic evidence, there is no reason to be agnostic as to this causality. Education also improves the opportunities of individuals to earn higher incomes (whether these opportunities can be materialized depends, among other circumstances, to a large degree on macroeconomic factors). Better education initiates a virtuous cycle: With higher education the personal estimation of knowledge increases, the demand for education grows, better schooling opens the opportunity for higher incomes which makes higher educational levels possible... But there is also a vicious cycle: Low education corresponds to a low estimation of the possible benefits of schooling, the subsequent demand for schooling remains low, this results in poor income-opportunities which leads to a continuous underestimation of schooling...

In order to break such a vicious cycle and to initiate a virtuous one, public action is indispensable. It is also justified by the positive externalities which may be triggered by schooling. But there is more scope for competition than usually accepted.

Following the experience of several Latin American countries, it is promising to initiate a voucher-program which gives parents a choice, increases their specific purchasing power and stimulates competition between schools. This demandaugmenting and competition-stimulating measure bust be supplemented by a regulative framework. Mandatory educational standards should be established and regional as well as local public authorities should control them.

A German specialty which was discussed in this context is the national apprenticeship system. It initiates competition between firms for the best trainees and it is complemented by a mandatory training in public schools. This 
system has contributed to a relative low level of youth unemployment in Germany.

A lesson which can be drawn from these experiences is that the quality of education and training can be improved by stimulating a competition process between suppliers and regulating this process by standard-setting authorities.

4) In the institutional framework of employment, „voice” is a productivity-augmenting alternative to „exit".

Germany has a rich experience with the codetermination and participation of workers; using the words of Hirschman: Workers have a 'voice' within the firm. This is being criticized by several reasons: Property rights may loose their clear profile, necessary decisions may be de delayed, the firm supposedly cannot adapt quickly enough to changing market conditions etc. The empirical evidence in favor of these hypotheses is weak.

However, the central point is the following one. Workers are more interested in accumulating firm-specific human capital if they have a „voice”, and this favors productivity-growth. Moreover, if workers have a say within the firm, adjustment by expanding and reducing work-hours may be facilitated. There is an empirical evidence for this in the German car-industry.

The alternative is an adjustment by „hire and fire" or „exit” as we may call it using Hirschman's terminology. This kind of flexibility makes it difficult to build a firm-specific stock of capital. "Voice" therefore is a productivityaugmenting alternative to ,exit”.

5) In social policy, the principle of subsidiarity should be respected, which means both: leaving room for private initiative and providing public safety-nets so that private actors are prevented from being overstressed.

The first part of this principle means that individual provision should be given priority over public one and private social networks should supplement individual responsibilities if necessary without being replaced by governmental actions. In Germany as well as in Latin American countries, numerous NonGovernmental Organizations (NGOs) are engaged in this field. It is impressive how the development of these NGOs contributes to the evolution of a ,civil society". In addition to their material assistance, these organizations offer an atmosphere of personal support and encouragement which no public administration can ever provide.

But NGOs cannot organize - for example - an extensive health insurance system or a pension scheme. They would be overstressed in doing so. They can play their role only if the state is playing its own. This is the second part of the principle. 
There are some indications that Latin American states not only leave responsibilities to NGOs where these organizations have a comparative advantage but also in cases where governmental actions are indispensable. This is a fundamental misunderstanding of subsidiarity. The principle is not used to shape a reasonable complementarity between private and public safety-nets, but to justify public passiveness.

6) Competition between providers improves the quality of health services; governmental action is necessary in order to secure an access to these services.

There is some evidence, that competition between medical doctors in urban centers increases the quality of their services and that competition between hospitals decreases costs (in rural areas with a scattered population there is no much scope for such competition). If insurers compete with each other, administrative costs can raise, as the Chilean experience shows. The main weakness, however, is the resulting „cream skimming” among customers. The high-risk/low-income-customers remain uninsured. Therefore, some public action is necessary in order to provide regular health services for these groups, which is justified by social considerations as well as by the social risk of individual illnesses.

The solution is a mandatory insurance combined with the guarantee of access to health services. There are many institutional arrangements which correspond to this approach. Some of the examples discussed are the following: Germany established a competitive system between health insurers combined with a risk compensation scheme which avoids "cream skimming” and offers access to health services for all. In Chile, competition between insurers is supplemented by the publicly guaranteed access to basic health care. Colombia guarantees a „minimum benefit package” for all.

In each case, market elements are combined with governmental regulations which include a re-distributive component. Without these governmental actions, part of the population would be excluded from health services and social risks would not be covered.

7) In order to prevent people from old age poverty, individual provision should supplement collective insurance schemes which should be designed in such a way, that private provision is not becoming suspended.

The problem of many industrialized countries is, that the interest in individual provision has been weakened by generous benefits offered within a „pay-asyou-go"-scheme. In some cases, retirement age was lowered without a corresponding reduction in pension claims. In addition to that, demographic changes caused severe problems. In many Latin American countries the traditional pension systems are unsustainable, apart from the fact that the 
claims within „pay-as-you-go"-schemes are frequently based on individual incomes received during the last five years of professional activity. The result is that contributions are under-declared during earlier periods of the professional life. In general, incentives were set in the wrong way.

Reforms, therefore, are due. Their details are debated very intensively, and they differ from country to country. But the common idea of these reforms seems to be the following: Within a mandatory, ,pay-as-you-go"-scheme, a minimumpension is guaranteed to all. Necessarily, this scheme includes some element of redistribution. Otherwise one cannot avoid old-age-security of those who earned very low incomes during their professional life. An additional voluntary old age insurance should be organized on a capital funded basis. In this way, individual providence supplements the collective one and is not suspended by the latter.

The general result of the discussion was, that we have a great variety of institutions which correspond to the public interest in „social justice”, defined as a distributional pattern of assets, income and rights which is accepted on widely shared moral reasons and which stabilizes the institutional framework of a free society. It will be difficult to effectuate market-oriented reforms when this interest is not taken into account. Buchanan already said the necessary: „Those economists who advise governments to proceed with actions contrary to the political interest... are likely to experience repeated frustration." ${ }^{1}$ Besides all moral reasons for implementing "social justice" in a market economy, this is a political one.

' Buchanan, J.M. (1986): Liberty, Market and State. Political Economy in the 1980ies, p.184, Brighton. 


\section{The Authors}

Prof. Dr. Knut Gerlach

Institut für Quantitative Wirtschaftsforschung, Fachbereich Wirtschaftswissenschaften, Universität Hannover, Königsworther Platz 1, 30167 Hannover

Klaus Liebig

Deutsches Institut für Entwicklungspolitik (DIE), Tulpenfeld 4, 53113 Bonn

Prof. Dr. Hans Jürgen Rösner

Seminar für Sozialpolitik, Universität zu Köln, Albertus-Magnus-Platz, 50931 Köln

Prof. Dr. Peter Rühmann

Wirtschaftswissenschaftliche Fakultät, Universität Göttingen, Platz der Göttinger Sieben 3, 37073 Göttingen

Prof. Dr. Hermann Sautter

Ibero-Amerika Instititut für Wirtschaftsforschung der Universität Göttingen, Gosslerstr. 1B, 37073 Göttingen

Dr. Rolf Schinke

Ibero-Amerika Institut für Wirtschaftsforschung der Universität Göttingen, Gosslerstr. 1B, 37073 Göttingen

Prof. Dr. Winfried Schmähl

Zentrum für Sozialpolitik, Universität Bremen, Parkallee 39, 28209 Bremen

Prof. Dr. J.-Matthias Graf von der Schulenburg

Institut für Versicherungsbetriebslehre, Fachbereich Wirtschaftswissenschaften, Universität Hannover, Königsworther Platz 1, 30167 Hannover 
Göttinger Studien zur Entwicklungsōkonomik

Göttingen Studles in Development Economics

Herausgegeben von / Edited by Hermann Sautter

Bd.Nol. 9 Hermann Sautter / Rolf Schinke (eds.): Social Justice in a Market Economy. 2001 